\title{
ESTABLISHMENT OF AN OIL AND GAS DATABASE FOR INCREASED RECOVERY AND CHARACTERIZATION OF JIL AND GAS CARBONATE RESERVOIR HETEROGENEITY
}

DOE Contract No. DE-FG22-89BC14425

APPENDIX 1

Draft Topical Report on Subtasks 2 and 3

Volume 1 of 4

\author{
PREPARED BY \\ David C. Kopaska-Merkel, Henry E. Moore, Jr., Steven D. Mann, \\ ano' Douglas R. Hall
}

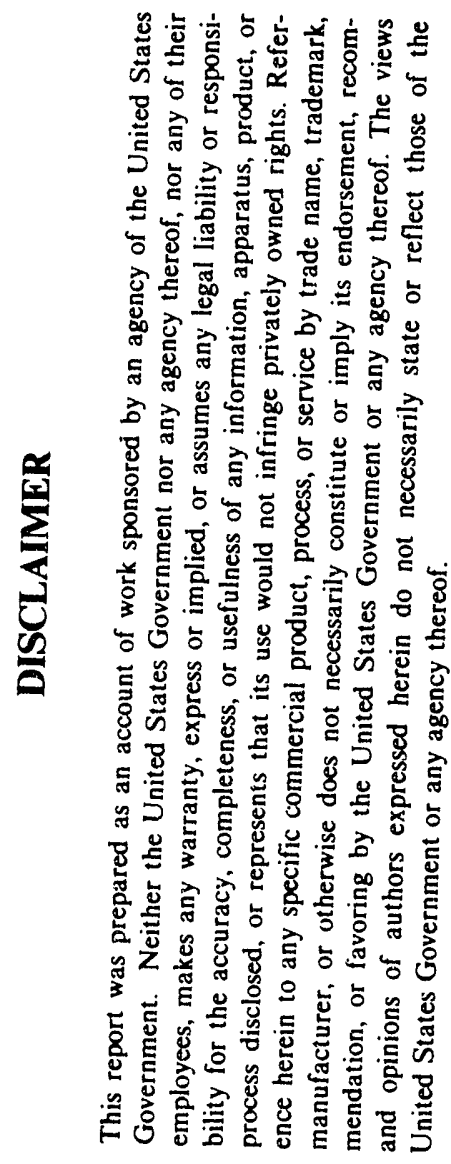

\author{
FOR \\ United States Department of Energy \\ Bartlesville Project Office \\ Bartlesville, Oklahoma
}

Project Manager: Chandra M. Nautiyal

June 1992 


\section{CONTENTS}

Field codes for Smackover oil fields in southwest Alabama

Page

Explanation of map symbols and abbrevitions .

Key to core logs

Abbreviations

Volume I

Appleton field, Smackover oil pool, Escambia County, Alabama . . . . . . . . . . . 1

Barnott field, Smackover oil pool, Conecuh and Escambia Counties, Alabama . . . . . . . 12

Barlow Bend field, Smackover oil pool, Clarke and Monroe Counties, Alabama . . . . . . 25

Barrytown field, Smackover oil pool, Choctaw County, Alabama . . . . . . . . . . . 33

Big Escambia Creek field, Smackover gas and condensate pool, Escambia

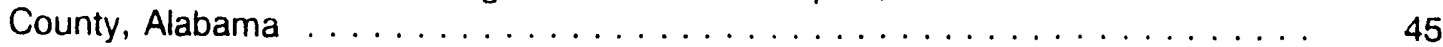

Blacksher field, Smackover oil pool, Baldwin County, Alabama . . . . . . . . . . . . 58

Broken Leg Creek field, Smackover oil pool, Escambia County, Alabama . . . . . . . . . 72

Bucatunna Creek field, Smackover oil pool, Chnctaw County, Alabama . . . . . . . . . . . 80

Burnt Corn Creek field,Smackover oil pool, Escambia County, Alabama . . . . . . . . . . . 95

Chappell Hill field, Smackover oil pool, Choctaw County, Alabama . . . . . . . . . . . . 105

Chatom field, Smackover gas and condensate ponl, Washington County, Alabama . . . . . 120

Choctaw Ridge field, Smackover oil pool, Choctaw County, Alabama . . . . . . . . . . . . 134

Chunchula field, Smackover gas and condensate pool, Mobile County, Alabama . . . . . 145

Cold Creek field, Smackover oil pool, Mobile County, Alabama . . . . . . . . . . . . . . 158

Copeland field, Smackover gas and condensate pool, Washington County, Alabama . . . 166

Crosbys Creek field, Smackover gas and condensate pool, Washington

County, Alabama . . . . . . . . . . . . . . . . . . . . . . . . . . . 174

East Barnett field, Smackover oil pool, Conecuh and Escambia Counties, Alabama . . . 185

Volume II

East Huxford field, Smackover oil pool, Escambia County, Alabama . . . . . . . . . . . 195

Fanny Church field, Smackover oil pool, Escambia County, Alabama . . . . . . . . . . . 202

Gin Creek field, Smackover oil pool, Choctaw County, Alabama . . . . . . . . . . . . 210

Gulf Crest field, Smackover oil pool, Mobile County, Alabaria . . . . . . . . . . . . . 224

Hanberry Church field, Smackover oil pool, Escambia County, Alabama . . . . . . . . . . 231

Hatter's Pond field, Smackover gas and condensate pool, Mobile County, Alabama . . . 238

Healing Springs field, Smackover gas and condensate pool,

Washington County, Alabama . . . . . . . . . . . . . . . . . . . 251

Huxford field, Smackover oil pool, Escambia County, Alabama . . . . . . . . . . . . . 264

Little Escambia Creek field, Smackover oil pool, Escambia County, Alabama . . . . . . . . . 277

Little Mill Creek field, Smackover oil pool, Choctaw Jounty, Alabama . . . . . . . . . . . . . . 294

Little River field, Smackover oil pool, Baldwin and Monroe Counties, Alabama . . . . . . . 302

Little Rock field, Smackover gas and condensate pool, Escambia County, Alabama . . . . 316

Lovetts Creek field, Smackover oil pool, Clarke and Monroe Counies, Alabama . . . . . . 323

Melvin field, Smackover oil pool, Choctaw County, Alabama . . . . . . . . . . . . . . 340

Mill Creek field, Smackover oil pool, Choctaw County, Alabama . . . . . . . . . . . . . 348

Mineola field, Smackover oil pool, Conecuh County, Alabama . . . . . . . . . . . . 356

Movico field, Smackover oil pool, Mobile and Baldwin Counties, Alabama . . . . . . . . . 363

North Choctaw Ridge field, Smackover oil pool, Choctaw County, Alabama . . . . . . . . 374

Volume III

North Smiths Church field, Smackover oil pool, Escambia County, Alabama . . . . . . 388

Nurth Wallers Creek field, Smackover oil pool, Monroe County, Alabama . . . . . . . . . . 395

Northeast Barnett field, Smackover oil pool, Conecuh County, Alabama . . . . . . . . . . 408

Northwest Range field, Smackover oil pool, Conecuh County, Alabama . . . . . . . . . . . 415

Pace Creek field, Smackover oil pool, Clarke County, Alabama . . . . . . . . . . . . . 422 


\section{CONTENTS-CONTINUED}

Palmers Crossroads field, Smackover oil pool, Monroe County, Alabama

Page

Perdido field, Smackover oil pool, Escambia and Baldwin Counties, Alabama . . . . . . . . .

Puss Cuss Creek field, Smackover oil pool, Choctaw County, Alabama . . . . . . . . . . .

Red Creek field, Smackover gas and condensate pool,

Washington County, Alabama ........................

Robinson Creek field, Smackover oil pool, Escambia County, Alabama . . . . . . . . .

Silas field, Smackover oil pool, Choctaw County, Alabama . . . . . . . . . . . . . . .

Sizemore Creek field, Smackover gas and condensate pool,

Escambia County, Alabama . . . . . . . . . . . . . . . . . . . .

Smiths Church field, Smackover gas and condensate pool,

Escambia County, Alabama

South Burnt Corn Creek field, Smackover oil pool, Escambia County, Alabama . . . . . . .

South Cold Creek field, Smackover oil pool, Mobile County, Alabama . . . . . . . . . . .

South Vocation field, Smackover oil pool, Monroe County, Alabama . . . . . . . . . . . .

South Wild Fork Creek field, Smackover gas and condensate pool,

Escambia County, Alabama . . . . . . . . . . . . . . . . .

South Womack Hill field, Smackover oil pool, Choctaw and

Clarke Counties, Alabama . . . . . . . . . . . . . . . . . .

Southeast Chatom field, Smackover gas and condensate pool,

Washington County, Alabama . . . . . . . . . . . . . . . . . . .

Southwest Barrytown field, Smackover oil pool, Choctaw County, Alabama . . . . . . . .

Souwilpa Creek field, Smackover gas and condensate pool,

Choctaw County, Alabama

Volume IV

Stave Creek field, Smackover oil pool, Clarke County, Alabama . . . . . . . . . . . .

Sugar Ridge field, Smackover oil pcol, Choctaw County, Alabama . . . . . . . . . . . .

Toxey field, Smackover oil pool, Choctaw County, Alabama . . . . . . . . . . . . . . . .

Turkey Creek field, Smackover oil pool, Choctaw and Clarke Counties, Alabama . . . . . . .

Turnerville field, Smackover oil pool, Mobile County, Alabama . . . . . . . . . . . . . .

Uriah field, Smackover oil pool, Monroe County, Alabama $\ldots \ldots \ldots \ldots \ldots \ldots \ldots$

Vocation field,Sackover oil pool, Monroe County, Alabama . . . . . . . . . . . . . .

Wallace field, Smackover oil pool, Escambia County, Alabama . . . . . . . . . . . . . .

Wallers Creek field, Smackover oil pool, Monroe County, Alabama . . . . . . . . . . . .

West Appleton field, Smackover oil pool, Escambia County, Alabama . . . . . . . . . . .

West Barrytown field, Smackover oil pool, Choctaw County, Alabama . . . . . . . . . . . .

West Bend field, Smackover oil pool, Choctaw and Clarke Counties, Alabama . . . . . . . .

672

686

West Okatuppa Creek field, Smackover oil pool, Choctaw County, Alabama . . . . . . . 699

Wild Fork Creek field, Smackover oil pool, Escambia County, Alabama . . . . . . . . . 706

Wimberly Field, Smackover oil pool, Choctaw County, Alabama . . . . . . . . . . . . 714

Womack Hill field, Smackover oil pool, Choctaw and Clarke Counties, Alabama . . . . . . 722

Zion Chapel field, Smackover oil pool, Choctaw County, Alabama . . . . . . . . . . 733 


\section{ILLUSTRATIONS}

APT-1. Index map of Appleton field, Alabama . . . . . . . . . . . . . . . .

APT-2. Structure contour map on top of Smackover Formation in Appleton field, Alabama ........................ 3

APT-3. Well log, McMillan 2-14 No. 1 well, Permit No. 3854, Appleton field, Alabama ........................... 4

APT-4.

Structural cross section of the Appleton field, Alabama $\ldots \ldots \ldots \ldots \ldots \ldots$

APT-5.

Graph of production history of the Appleton field, Alabama

APT-6. Porosity vs. natural log permeability plot of described core from

D. W. McMillan 2-15 No. 5 well, Permit No. 6247, Appleton field,

Alabama.

APT-7. Detailed core log, D. W. McMillan 2-15 No. 5 well, Permit No. 6247, Appleton field, Alabama

APT-8. Paragenetic sequence, D. W. McMillan 2-15 No. 5 well, Permit No. 6247, Appleton field, Alabama ... . . . . . . . . . . . . . . . . . . . . . . 11

BAR-1. Index map of Barnett field, Alabama . . . . . . . . . . . . . . . . . . . .

BAR-2. Structure contour map on top of Smackover Formation in Barnett field, Alabama . . . . . . . . . . . . .

BAR-3. Well log correlated to lithology, porosity, and permeability, Alger Sullivan "C" No. 1 well, Permit No. 1827, Barnett field,

Alabama . . . . . . . . . . . . . . . . . . . . . .

BAR-4.

BAR-5.

BAR-6.

BAR-7.

Structural cross section of the Barnett field, Alabama $\ldots \ldots \ldots \ldots \ldots \ldots \ldots$

Graph of production history of the Barnett field, Alabama $\ldots \ldots \ldots \ldots \ldots \ldots . . \ldots 17$

Porosity vs. natural log permeability plots, Barnett field, Alabama . . . . . . . 18

Detailed core log, Alger Sullivan "C" No. 1 well, Permit No. 1827-A, Barnett field, Alabama . . . . . . . . . . . . . . . . . . . . .

BAR-8. Porosity vs. natural log permeability plot, Alger Sullivan " $\mathrm{C}$ " No. 1 well, Permit No. 1827-A, Barnett field, Alabama . . . . . . . . . . . . . . . .

BAR-9. Paragenetic sequence, Alger Sullivan "C" No. 1 well, Permit No. 1827-A, Barnett field, Alabama . . . . . . . . . . . . . . . . . . . .

BAR-10. Ternary diagram of pore types, Alger Sullivan "C" No. 1 well, Permit No. 1827-A, Barnett field, Alabama . . . . . . . . . . . . . . . . .

BB-1. Index map of Barlow Bend tield, Alabama . . . . . . . . . . . . . . .

BB-2. Structure contour map on top of Smackover Formation in Barlow Bend field, Alabama

BB-3.

Well log, Henry Gibby Unit 7-15 No. 1 well, Permit No. 4905, Barlow

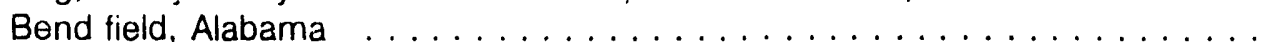

Structural cross section of the Barlow Bend field, Alabama . . . . . . . . . . . . .

BB-5. Graph of production history of the Barlow Bend field, Alabama . . . . . . . . . . .

BB-6.

Porosity vs. natural log permeability plot of John R. Mattmuller et al.

No. 1 well, Permit No. 2708, Barlow Bend field, Alabama . . . . . . . . . . Index map of Barrytown field, Alabama . . . . . . . . . . . . . . . 34

BTN-1. Structure contour map on top of Smackover Formation in Barrytown

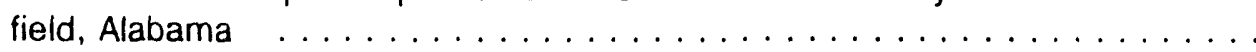

BTN-3. Well log correlated to lithology and permeability, Mclllwain 11-10 well, Permit No. 1818, Barrytown field, Alabama

BTN-4.

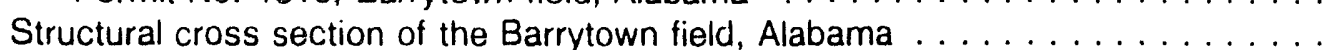




\section{ILLUSTRATIONS-CONTINUED}

Page

BTN-8. Porosity vs. natural log permeability plot for lithofacies 1, Mclllwain 11-10 No. 1 well, Permit No. 1818, Barrytown tield, Alabama

BTN-9. Paragenetic sequence, Mclllwaln 11-10 No. 1 well. Permit No. 1818 , Barrytown field, Alabama ......................... 44

BEC-1 Index map of Big Escambia Creek field, Alabama . . . . . . . . . . . . . .

BEC-2. Structure contour map on top of Smackover Formation in Big Escambia

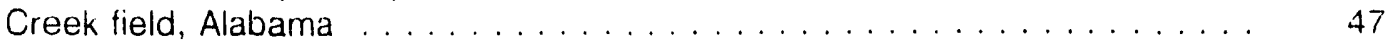

BEC-3. Well log correlated to lithology, porosity, and permeability, Smith 25-7 No. 1 well. Permit 4727, Big Escambia Creek field, Alabama . . . 48

$B E C-4$ BEC-5 BEC-6.

Structural cross section of the Big Escambia Creek field, Alabama . . . . . . . . . Graph of production history of the Big Escambia Creek tield, Alabama

Porosity vs. natural log permeability plots, Big Escambia Creek field, Alabama

BEC- 7

Detailed core log, Smith 25-7 No. 1 well, Permıt No. 4727, Big Escambia Creek field, Alabama ... . . . . . . . . . . . . . . .

BEC-8

Porosity vs. natural log permeability plots for three lithofacies, Sinith 25-7

No. 1 well, Permit No. 4727, Big Escambia Creek field, Alabama . . . . . . . . .

BEC-9. Paragenetic sequence, Smith 25.7 No. 1 well, Permit No. 4727, Big Escambia Creek field, Alabama . . . . . . . . . . . . . . . . . . . . . . .

BLS-1. Index map of Blacksher field, Alabama . . . . . . . . . . . . . . . .

BLS-2. Structure contour map on top of Smackover Formation in Blacksher

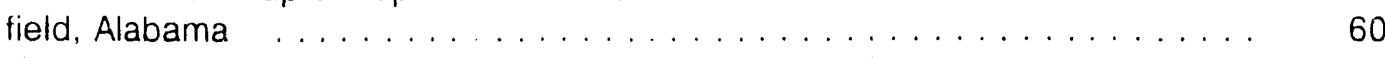

BLS-3. Well log correlated to lithology, porosity, and permeability, International

Paper Co. 20-5 No. 1 well, Permit No. 5242, Blacksher field, Alabarna . . . . .

Structural cross section of the Blacksher field. Alabama . . . . . . . . . . . .

Graph of production history of the Blacksher field. Alabama . . . . . . . . . . 63

Porosity vs. natural log permeability plots, Blacksher field, Alabarna . . . . . . . 64

BLS.8.

Detailed core log, International Paper Co. 20-5 No. 1 well, Permıt No. 5242,

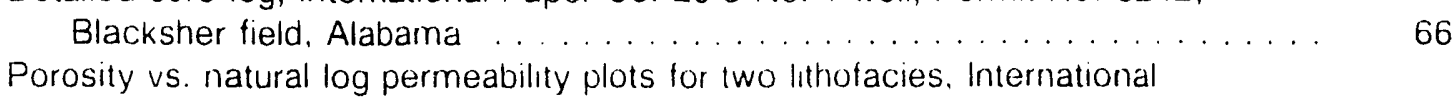

Paper Co. 20-5 No. 1 well. Permit No. 5242. Blacksher field, Alabama . . . . .

BLS-9.

Paragenetic sequence, International Paper Co. 20-5 No. 1 well,

Permit No. 5242, Blacksher field. Alabarna . . . . . . . . . . . . . . . 70

BLS-10. Ternary diagram of pore types, Internatıonal Paper Co. 20-5 No. 1 well,

Permit No. 5242, Blacksher field, Alabaina ... . . . . . . . . . . . 7

BLC-1.

Index map of Broken Leg Creek field. Alabama . . . . . . . . . . . . . . . 73

BLC-2. Structure contour map on top of Smackover Formation in Broken Leg Creek field, Alabama field. Alabama ...... . . . . . . . . . . . . . . . . . . . 75

BLC.4.

BLC-5.

Structural cross section of the Brrken Leg Creek field, Alabama . . . . . . . . . . Graph of production history of the Broken Leg Creek field, Alabama . . . . . . . . . Porosity vs. natural log permeability plot of one core, Broken Leg Creek field, Alabama

BUC-3.

Well log. A. G. Harrell No. 1 well. Permıt No. 2470, Bucatunna Creek field, Alabama 


\section{ILLUSTRATIONS-CONTINUED}

Page

BUC-6. Porosity vs. natural log permeability plots, Bucatunna Creek field,

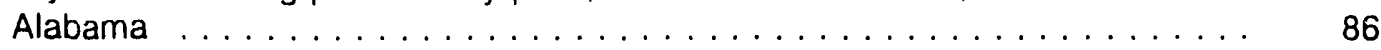

BUC-7. Detailed core log, Johnson Unit 14-14 No. 1 well, Permit No. 2753 , Bucatunna Creek field, Alabama ...................... 88

BUC-8. Porosity vs. natural log permeability plot for lithofacies 1, Johnson Unit 14-14 No. 1 well, Permit No. 2753-B, Bucatunna Creek field, Alabama . . . . 92

BUC-9. Paragenetic sequence, Johnson Unit 14-14 No. 1 well, Permit No. 2753, Bucatunna Creek field, Alabama . . . . . . . . . . . . . . . . 93

BUC-10. Ternary diagram of pore types, Johnson Unit 14-14 No. 1 well, Permit No. 2753, Bucatunna Creek field, Alabama .................. 94

BCC-1. Index map of Burnt Corn Creek field, Alabama . . . . . . . . . . . . . .

BCC-2. Structure contour map on top of Smackover Formation in Burnt Corn Creek field, Alabama . . . . . . . . . . . . . . . . . . . .

BCC-3.

Well $\log$, A. J. Smith 3-14 No. 1 well, Permit No. 4744, Burnt Corn Creek field, Alabama ...........................

BCC-4. Structural cross section of the Burnt Corn Creek field, Alabama . . . . . . . . . .

BCC-5. Graph of production history of the Burnt Corn Creek field, Alabama Burnt Corn Creek field, Alabama . . . . . . . . . . . . . . . .

BCC-7. Paragenetic sequence, Hooper Mathews 4-8 No. 1 well, Permit No. 2377, Burnt Corn Creek field, Alabama . . . . . . . . . . . . . . . .

$\mathrm{CH}-1$.

$\mathrm{CH}-2$.

Index map of Chappell Hill field, Alabama . . . . . . . . . . . . . . .

Structure contour map on top of Smackover Formation in Chappell Hill field, Alabama

Well log correlated to lithology, porosity, and permeability, Bolinger 26-7

$\mathrm{CH}-3$.

No. 1 well, Permit No. 2426, Chappell Hill field, Alabama . . . . . . . . . .

$\mathrm{CH}-4$.

$\mathrm{CH}-5$.

$\mathrm{CH}-6$.

$\mathrm{CH}-7$.

Structural cross section of the Chappell Hill field, Alabama . . . . . . . . . . . .

Graph of production history of the Chappell Hill field, Alabama . . . . . . . . . .

Porosity vs. natural log permeability plots, Chappell Hill field, Alabama . . . . . . . .

Detailed core log, Bolinger 26-7 No. 1 well, Permit No. 2426, Chappell

Hill field, Alabama . . . . . . . . . . . . . . . . . . .

$\mathrm{CH}-8$.

Porosity vs. natural log permeability plots for three lithofacies, Bolinger 26-7 No. 1 well, Permit No. 2426, Chappell Hill field, Alabama . . . .

$\mathrm{CH}-9$.

Paragenetic sequence, Bolinger 26-7 No. 1 well, Permit No. 2426, Chappell Hill field, Alabama . . . . . . . . . . . . . . . . . . . . .

$\mathrm{CH}-10$.

Ternary diagram of pore types, Bolinger 26-7 No. 1 well, Permit No. 2426, Chappell Hill field, Alabama $\ldots \ldots \ldots \ldots \ldots \ldots \ldots \ldots \ldots$

CTM-1. Index map of Chatom field, Alabama $\ldots \ldots \ldots \ldots \ldots \ldots \ldots \ldots$ CTM-2.

Structure contour map on top of Smackover Formation in Chatom field, Alabama ...........................

CTM-3.

Well log correlated to lithology, porosity, and permeability, Chatom Unit 20-14 No. 1-04 well, Permit No. 7044, Chatom field, Alabama . . . . . .

CTM-4. Structural cross section of the Chatom field, Alabama $\ldots \ldots \ldots \ldots \ldots \ldots$ 


\section{ILLUSTRATIONS-CONTINUED}

CTM-10. Ternary diagram of pore types, Chatorn Unit 20-14 No. 1-04 well, Permit No. 7044, Chatom field, Alabama . . . . . . . . . . . . . . . . 133

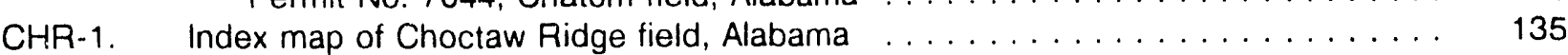

CHR-2. Structure contour map on top of Smackover Formation in Choctaw Ridge field, Alabama ...........................

CHR-3. Well log correlated to lithology, Rentz-Trice Unit 35-1 well, Permit No. 1427, Choctaw Ridge field, Alabama . . . . . . . . . . .

CHR-4. Structural cross section of the Choctaw Ridge field, Alabama . . . . . . . . . .

CHR-5. Graph of production history of the Choctaw Ridge field, Alabama . . . . . . . . .

CHR-6. Porosity vs. natural log permeability plot of five cores combined, Choctaw Ridge field, Alabama . . . . . . . . . . . . . . . . . . . . . 140

CHR-7. Detailed core log, Rentz-Trice Unit 35-1 well, Permit No. 1427, Choctaw Ridge field, Alabama . . . . . . . . . . . . . . . . . . . . . 142

CHR-8. Paragenetic sequence, Rentz-Trice Unit 35-1 No. 1 well, Permit No. 1427, Choctaw Ridge field, Alabama . . . . . . . . . . . . . . . . . . . . . . 144

CHU-1. CHU-2. Index map of Chunchula field, Alabama . . . . . . . . . . . . . . . Structure contour map on top of Smackover Formation in Chunchula

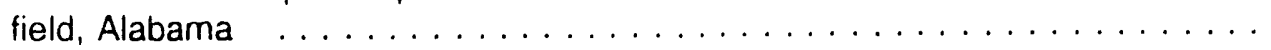

Well log correlated to lithology, porosity, and permeability, Annie M. Hill et al. 10-10 No. 1 well, Permit No. 2218, Chunchula field, Alabama . . . . . . .

Structural cross section of the Chunchula field, Alabama $\ldots \ldots \ldots \ldots \ldots \ldots$

CHU-4. Graph of production history of the Chunchula field, Alabama . . . . . . . . .

Detailed core log, Annie M. Hill et al. 10-10 No. 1 well, Permit No. 2218, Chunchula field, Alabama $\ldots \ldots \ldots \ldots \ldots \ldots \ldots \ldots$

C.HU-8.

Porosity vs. natural log permeability plot for lithofacies 1 , Annie M. Hill et al. 10-10 No. 1 well, Permit No. 2218, Chunchula field, Alabama

CHU-9.

Paragenetic sequence, Annie M. Hill et al. 10-10 No. 1 well, Permit No. 2218, Chunchula field, Alabama

CHU-10.

Ternary diagram of pore types, samples from several wells, Chunchula field, Alabama

CC-1.

Index map of Cold Creek field, Alabama

Structure contour map on top of Smackover Formation in Cold Creek

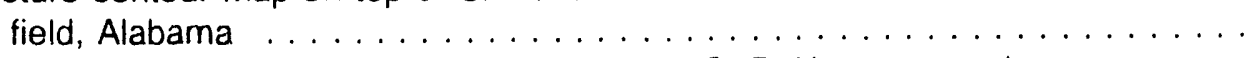

Well $\log$ correlated to porosity and permeability, C. P. Newman et al. 8-16 No. 1 well, Permit No. 3027, Cold Creek field, Alabama . . . . . . . . .

Structural cross section of the Cold Creek field, Alabama . . . . . . . . . . . . .

Structure contour map on top of Smackover Formation in Copeland

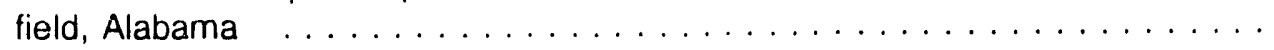

Well log, Edith Burch 30-13 No. 1 well, Permit No. 3247, Copeland

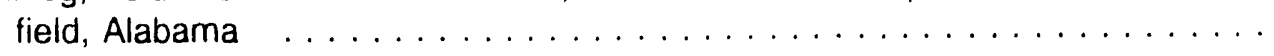

CAC-2. Structure contour map on top of Smackover Formation in Crosbys

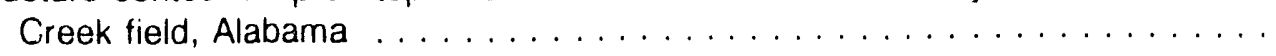




\section{ILLUSTRATIONS-CONTINUED}

CRC-3. Well log, Sarah Middleton 34-11 No. 1 well, Permit No. 5001, Crosbys

Creek field, Alabama . . . . . . . . . . . . . . . . . . . . . . . . 177

CRC-4. Structural cross section of the Crosbys Creek field, Alabama . . . . . . . . . . 178

CRC-5. Graph of production history of the Crosbys Creek field, Alabama . . . . . . . 179

CRC-6. Porosity vs. natural log permeability plot of two cores combined,

Crosbys Creek field, Alabama $\ldots \ldots \ldots \ldots \ldots \ldots . \ldots \ldots$. . . . . . . . 180

CRC-7. Detailed core log, Darly Dees 3-3 No. 1 well, Permit No. 5115, Crosbys Creek field, Alabama . . . . . . . . . . . . . . . . . . . . . . 182

CRC-8. Paragenetic sequence, Darly Dees 3-3 No. 1 well, Permit No. 5115, Crosbys Creek field, Alabama . . . . . . . . . . . . . . . . . . . . . 184

EB-1. Index map of East Barnett field, Alabama . . . . . . . . . . . . . . . . . 186

EB-2. Structure contour map on top of Smackover Formation in East Barnett field, Alabama . .........................

Well log correlated to lithology, Scott Paper Co. et al. 1-1 No. 1 well, Permit No. 5740, East Barnett field, Alabama . . . . . . . . . . . . . .

Structural cross section of the East Barnett field, Alabama . . . . . . . . . . . 189

EB-4.

EB-5.

EB-6.

Graph of production history of the East Barnett field, Alabama . . . . . . . . .

Detailed core log, Scott Paper Co. 1-1 No. 1 well, Permit No. 5740, East Barnett field, Alabama . . . . . . . . . . . . . . . . . . . . . . 192

EB-7. Paragenetic sequence, Scott Paper Co. 1-1 No. 1 well, Permit No. 5740, East Barnett field, Alabama ... . . . . . . . . . . . . . . . .

$\mathrm{EH}-1$.

$\mathrm{EH}-2$.

Index map of East Huxford field, Alabama . . . . . . . . . . . . . . . . . .

Structure contour map on top of Smackover Formation in East Huxford field, Alabama .............................

EH-3. Well log, A.T.I.C. 18-13 No. 1 well, Permit No. 6804, East Huxford field,

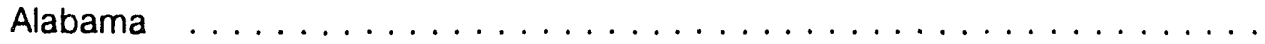

Structural cross section of the East Huxford field, Alabama $\ldots \ldots \ldots \ldots \ldots$

Graph of production history of the East Huxford field, Alabama . . . . . . . . . .

Index map of Fanny Church field, Alabama . . . . . . . . . . . . . .

Structure contour map on top of Smackover Formation in Fanny Church

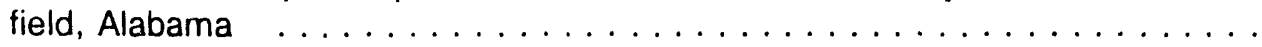

FC-3. Well log, D. J. Steely 36-2 well, Permit No. 1869, Fanny Church field,

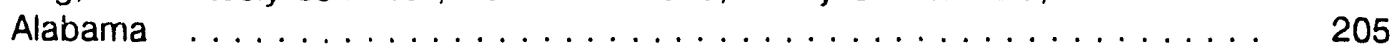

FC-4. Structural cross section of the Fanny Church field, Alabama . . . . . . . . . . 206

FC-5. Graph of production history of the Fanny Church field, Alabama . . . . . . . . . 207

FC-6. Porosity vs. natural log permeability plot of 19 cores combined, Fanny Church field, Alabama . . . . . . . . . . . . . . . . . . . . . . . 208

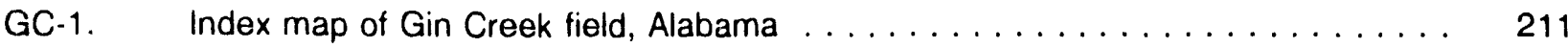

GC-2. Structure contour map on top of Smackover Formation in Gin Creek

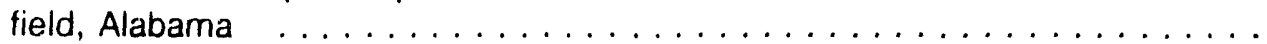

GC-3. Well log, Choctaw Lumber Co. $31-5$ No. 1 well, Permit No. 4546, Gin Creek field, Alabama . . . . . . . . . . . . . . . . . . . . 213

GC-4. Structural cross section of the Gin Creek field, Alabama . . . . . . . . . . . 214

GC-5.

GC-6.

Graph of production history of the Gin Creek field, Alabama . . . . . . . . . .

Porosity vs. natural log permeability plot of described core for Bolinger Heirs 32-5 No. 1 well, Permit No. 3312, Gin Creek field, Alabama

GC-7. Detailed core log, Bolinger Heirs 32-5 No. 1 well, Permit No. 3312,

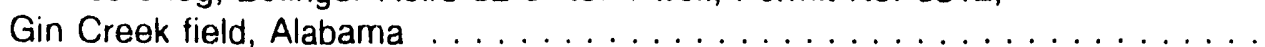

GC-8. Porosity vs. natural log permeability plots for three lithofacies, Bolinger Heirs 32-5 No. 1 well, Permit No. 3312, Gin Creek field, Alabama 


\section{ILLUSTRATIONS-CONTINUED}

GC-9. Paragenetic sequence, Bolinger Heirs 32-5 No. 1 well, Permit No. 3312,

Gin Creek field, Alabama . . . . . . . . . . . . . . . . . . . .

GC-10.

Ternary diagram of pore types, Bolinger heirs $32-5$ No. 1 well, Permit

No. 3312, Gin Creek field, Alabama

223

GUC-1.

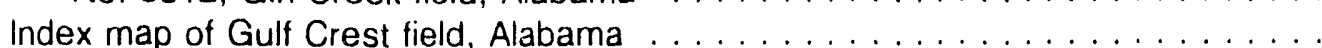

225

GUC-2. Structure contour map on top of Smackover Formation in Gulf Crest

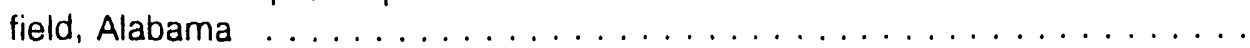

GUC-3.

Well $\log$, M. H. Brown Trust 5-2 No. 1 well, Permit No. 5226, Gulf

Crest field, Alabama . . . . . . . . . . . . . . . . . .

227

GUC-4.

Structural cross section of the Gulf Crest field, Alabama . . . . . . . . . . .

228

GUC-5.

Graph of production history of the Gulf Crest field, Alabama . . . . . . . . . . .

229

$\mathrm{HC}-1$.

Index map of Hanberry Church field, Alabama . . . . . . . . . . . . . . .

232

$\mathrm{HC}-2$.

Structure contour map on top of Smackover Formation in Hanberry

Church field, Alabama .........................

233

HC-3.

Well log, Huxford 34-2 No. 1 well, Permit No. 5178, Hanberry Church

field, Alabama ..........................

234

Structural cross section of the Hanberry Church field, Alabama . . . . . . . . . 235

HC-4.

HC-5.

Graph of production history of the Hanberry Church field, Alabama . . . . . . . . .

Index map of Hatter's Pond field, Alabama . . . . . . . . . . . . . . . .

236

HP-1.

HP-2.

Structure contour map on top of Smackover Formation in Hatter's

Pond field, Alabama . . . . . . . . . . . . . . . . . . . .

239

240

HP-3. Well log correlated to lithology, porosity, and permeability, Hatter's

Pond Unit 10-3 No. 1 well, Permit No. 6846, Hatter's Pond

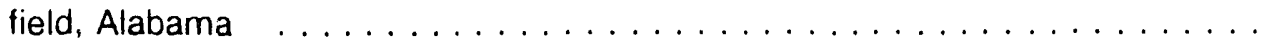

Structural cross section of the Hatter's Pond field, Alabama . . . . . . . . . .

242

HP-5.

Graph of production history of the Hatter's Pond field, Alabama . . . . . . . . .

243

HP-6.

Porosity vs. natural log permeability plot, Hatter's Pond field, Alabama

244

HP.7.

Detailed core log, Hatter's Pond Unit 10-3 No. 1 well, Permit No. 6846, Hatter's Pond field, Alabama

HP-8. Porosity vs. natural log permeability plots for three lithofacies, Hatter's Pond Unit 10-3 No. 1 well, Permit No. 6846, Hatter's Pond

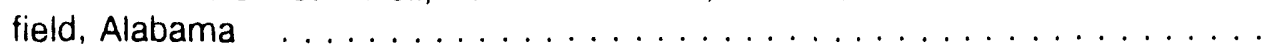

HP-9.

Paragenetic sequence, Hatter's Pond Unit 10-3 No. 1 well, Permit No. 6846, Hatter's Pond field, Alabama . . . . . . . . . . . . . . . .

HS-1. Index map of Healing Springs field, Alabama . . . . . . . . . . . . . . . .

HS-2. Structure contour map on top of Smackover Formation in Healing Springs field, Alabama . . . . . . . . . . . . . . . . . . .

HS-3.

Well log correlated to porosity and pe!meability, W. J. Britton No. 1 well,

Permit No. 2478, Healing Springs field, Alabama . . . . . . . . . . .

Structural cross section of the Healing Springs field, Alabama $\ldots \ldots \ldots \ldots \ldots$

HS-4.

HS-5.

HS-6.

Graph of production history of the Healing Springs field, Alabama . . . . . . . .

Porosity vs. natural log permeability plot, Healing Springs field, Alabama . . . . . .

Detailed core $\log$, W. J. Britton No. 1 well, Permit No. 2478, Healing Springs field, Alabama . . . . . . . . . . . . . . . . . . .

HS-8.

Porosity vs. natural log permeability plots for two lithofacies, W. J. Britton No. 1 well, Permit No. 2478, Healing Springs field, Alabama . . . . . . . . . .

HS-9.

Paragenetic sequence, W. J. Britton No. 1 well, Permit No. 2478, Healing

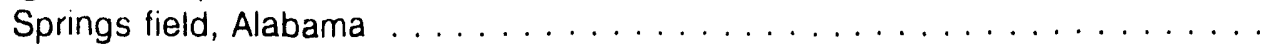

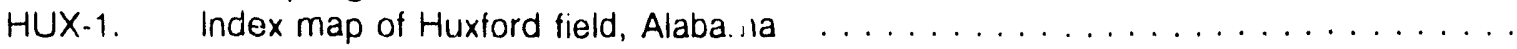

HUX-2. Structure contour map on top of Smackover Formation in Huxford $\ldots \ldots \ldots \ldots$ field, Alabarna 


\section{ILLUSTRATIONS-CONTINUED}

Page

HUX-3. Well log correlated to lithology, porosity, and permeability, M. H. Murphy

26-11 No. 1 well, Permit No. 4577, Huxford field, Alabama . . . . . . . . . . .

267

268

269

270

272

274

275

HUX-10. Ternary diagram of pore types, Murphy 26-11 No. 1 well, Permit No. 4577, Huxford field, Alabama .......................

276

278

279

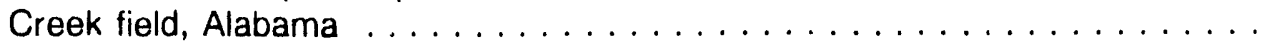

Well log correlated to lithology, porosity, and permeability, T. R. Miller Mill Unit 32-3 well, Permit No. 1654, Little Escambia Creek

field, Alabama

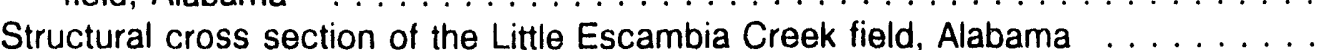

280

281

282

Porosity vs. natural log permeability plots, Little Escambia Creek

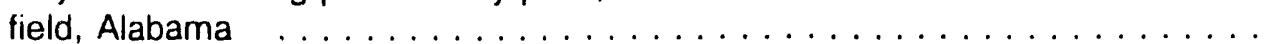

283

285

No. 1654, Little Escambia Creek field, Alabama . . . . . . . . . . . . . . .

Porosity vs. natural log permeability plots for three lithofacies, T. R. Miller Mill Unit 32-3 well, Permit No. 1654, Little Escambia Creek

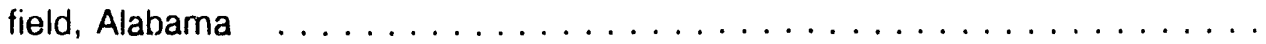

291

293

295

296

297

298

299

Graph of production history of the Little Mill Creek field, Alabama . . . . . . . . .

Porosity vs. natural log permeability plot of four cores combined, Little

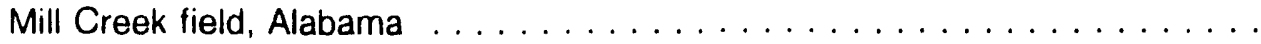

300

303

Index map of Little River field, Alabama ...................
Structure contour map on top of Smackover Formation in Little River

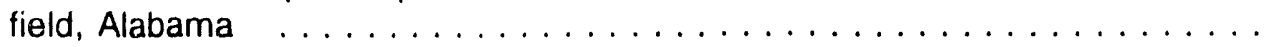

304

305

306

307

308

310 


\section{ILLUSTRATIONS-CONTINUED}

LR-8. Porosity vs. natural log permeability plot for lithofacies 1, Robinson 11-8

No. 1 well, Permit No. 3046, Little River field, Alabama . . . . . . . . . . . 313

LR-9. Paragenetic sequence, Robinson et al. 11-8 No. 1 well, Permit No. 3046, Little River field, Alabama ........................ 314

LR-10. Ternary diagram of pore types, Robinson et al. 11-8 No. 1 well, Permit No. 3046, Little River field, Alabama . . . . . . . . . . . . . . . . . . . . . 315

LRK-1. Index map of Little Rock field, Alabama $\ldots \ldots \ldots \ldots \ldots \ldots \ldots \ldots \ldots$

LRK-2. Structure contour map on top of Smackover Furmation in Little Rock

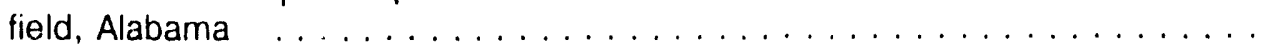

LRK-3. Well log, A.T.I.C. 31-6 No. 1 well, Permit No. 4303-B, Little Rock field, Alabama ..........................

LRK-4.

Structural cross section of the Little Rock field, Alabama . . . . . . . . . . . .

LRK-5.

Graph of production history of the Little Rock field, Alabarna $\ldots \ldots \ldots \ldots \ldots$

LOV -1. Index map of Lovetts Creek field, Alabama . . . . . . . . . . . . . . . .

LOV-2.

Structure contour map on top of Smackover Formation in Lovetts

Creek field, Alabama . . . . . . . . . . . . . . . . . . . . .

LOV-3.

Well log correlated to porosity and permeability, W. E. Broughton 11-6 No. 1 well, Permit No. 3347, Lovetts Creek field, Alabama

LOV-4.

LOV-5.

LOV-6.

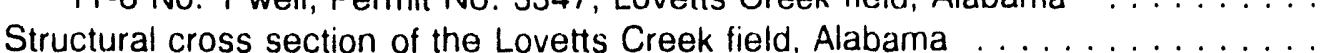

326

Graph of production history of the Lovetts Creek field, Alabama . . . . . . . . . 328

Porosity vs. natural log permeability plots, Lovetts Creek field, Alabama . . . . . . 329

LOV-7.

Detailed core log, W. M. Threat 11-10 No. 1 well, Permit No. 3535 , Lovetts Creek field, Alabama . . . . . . . . . . . . . . . . . . .

LOV-8. Porosity vs. natural log permeability plots for two lithofacies, W. M. Threat 11-10 No. 1 well, Permit No. 3535, Lovetts Creek field, Alabama . . . . . . . .

LOV-9.

Paragenetic sequence, W. M. Threat 11-10 No. 1 well, Permit No. 3535,

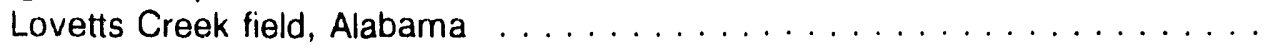

LOV-10. Ternary diagram of pore types, W. M. Threat 11-10 No. 1 well, Permit No. 3535, Lovetts Creek field, Alabama . . . . . . . . . . . .

MEL-1. Index map of Melvin field, Alabama $\ldots \ldots \ldots \ldots \ldots \ldots \ldots \ldots \ldots$

MEL-2. Structure contour map on top of Smackover Formation in Melvin

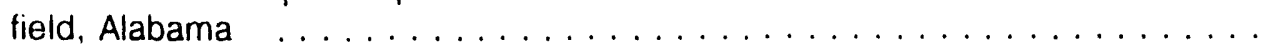

MEL-3. Well log, Charles M. Land 2-4 No. 1 well, Permit No. 2319, Melvin

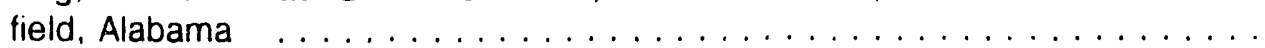

MEL-4.

Structural cross section of the Melvin field, Alabama $\ldots \ldots \ldots \ldots \ldots \ldots$

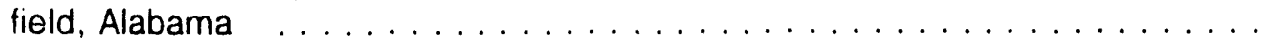

MC-2.

Structure contour map on top of Smackover Formation in Mill Creek field, Alabama $\ldots \ldots \ldots \ldots \ldots \ldots \ldots \ldots \ldots \ldots \ldots$

MC-3. Well log, Trice Unit 6-6 No. 1 well, Permit No. 2145, Mill Creek

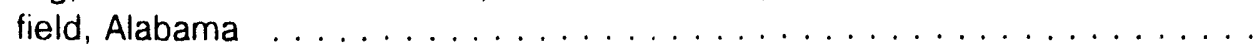

MC-4.

MC-5.

MC-6.

MIN-1. Structural cross section of the Mill Creek field, Alabama . . . . . . . . . . .

Graph of production history of the Mill Creek field, Alabarna

Porosity vs. natural log permeability plot of five cores combined, Mill Creek field, Alabama 


\section{ILLUSTRATIONS-CONTINUED}

Page

MIN-3. Well log, Langford 18-14 No. 1 well, Permit No. 8748,

Mineola field, Alabama ... . . . . . . . . . . . . . . . . . . . . 359

MIN-4.

MIN-5.

MOV-1.

MOV-2.

MOV-3.

MOV-4.

MOV.5.

MOV-6.

Structural cross section of the Mineola field, Alabama $\ldots \ldots \ldots \ldots \ldots \ldots$

Graph of production history of the Mineola field, Alabama . . . . . . . . . .

Index map of Movico field, Alabama

Structure contour map on top of Sinackover Formation in

Movico field, Alabama

360

361

364

365

Well log correlated to porosity and permeability, Janice R. Sullivan

et al. 9-4 No. 1 well. Permit No. 2126, Movico field, Alabama

366

367

368

Graph of production history of the Movico field, Alabama $\ldots . .$.
Porosity vs. natural log permeabillty plot of two cores combined,

Movico field, Alabama . . . . . . . . . . . . . . . . . . . .

369

MOV-7.

Detailed core log, Sullivan et al. 9.4 No. 1 well, Permit No. 2126,

Movico field, Alabama . . . . . . . . . . . . . . . . . .

371

373

375

376

377

378

379

Graph of production history of the North Choctaw Ridge field, Alabama

Porosity vs. natural log permeability plots, North Choctaw

Ridge field, Alabama

380

Detailed core log, Oates Unit 29-6 No. 1 well, Permit No. 1878

North Choctaw Ridge field, Alabama . . . . . . . . . . . . . . . .

382

Porosity vs. natural log permeability plots for three lithofacies, Oates Unit

29-6 No. 1 well, Permit No. 1878, North Choctaw Ridge field, Alabama

385

Paragenetic sequence, Oates Unit 29-6 No. 1 well, Permit No. 1878,

North Choctaw Ridge field, Alabama

386

NCR-10.

Ternary diagram of pore types, Oates Unit 29-6 No. 1 well, Permit No. 1878 ,

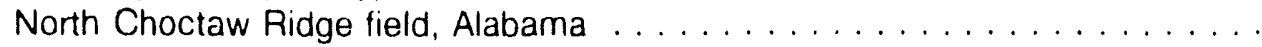

387

389

NSC-2. Structure contour map on top of Smackover Formation in North

Smiths Church field. Alabarna

390

NSC-3.

Well log. Edge-Wefel Trust 24.5 No. 1 well, Permit No. 6943, North

Smiths Church field, Alabama

391

392

Structural cross section of the North Smiths Church field, Alabama . . . . . . . . . .

Graph of production history of the North Smiths Church field, Alabama . . . . . . .

Index map of North Wallers Creek field, Alabama . . . . . . . . . . . . . . . .

Structure contour map on top of Smackover Formation in North Wallers

Creek field, Alabama

393

396

NWC-1.

NWC-3.

Well log correlated to lithology, porosity, and permeability, Irvin Langford

5-10 No. 1 well, Permit No. 7589, North Wallers Creek field, Alabama

397

398

399

400

NWC-5.

Structural cross section of the North Wallers Creek field, Alabama

Graph of production history of the North Wallers Creek field, Alabama . . . . . . . .

Porosity vs. natural log permeability plot of described core for Irvin Langford

5-10 No. 1 well, Permit No. 7589, North Wallers Creek field, Alabama 


\section{ILLUSTRATIONS-CONTINUED}

NWC-7. Detailed core log, Irvin Langford 5-10 No. 1 well, Permit No. 7589,

North Wallers Creek field, Alabama . . . . . . . . . . . . . . . . 403

NWC-8. Porosity vs. natural log permeability plot for lithofacies 1, Irvin Langford

5-10 No. 1 well, Permit No. 7589, North Wallers Creek field, Alabama ..... 406

NWC-9. Paragenetic sequence, Irvin Langford 5-10 No. 1 well, Permit No. 7589,

North Wallers Creek field, Alabama _. . . . . . . . . . . . . . . . . . 407

NEB-1. Index map of Northeast Barnett field, Alabama . . . . . . . . . . . . . . . 409

NEB-2. Structure contour map on top of Smackover Formation in Northeast

Barnett field, Alabama . . . . . . . . . . . . . . . . . . .

NEB-3. Well log, Scott Paper Co. 25-13 No. 1 well, Permit No. 7214, Northeast

Barnett field, Alabama . . . . . . . . . . . . . . . . . . . . . . 411

NEB-4. Structural cross section of the Northeast Barnett field, Alabama . . . . . . . . .

NEB-5.

NWR-1.

Graph of production history of the Northeast Barnett field, Alabama . . . . . . . .

413

Index map of Northwest Range field, Alabama . . . . . . . . . . . . . . . 416

NWR-2. Structure cuntour map on top of Smackover Formation in Northwest

Range field, Alabama .....................

NWR-3. Well log, Paramount A.T.I.C. 7-13 No. 1 well, Permit No. 5930, Northwest

Range field, Alabama ... . . . . . . . . . . . . . . . . . . . 418

NWR-4. Structural cross section of the Northwest Range field, Alabama . . . . . . . . . 419

NWR-5. Graph of production history of the Northwest Range field, Alabama . . . . . . . . 420

PC-1.

Index map of Pace Creek field, Alabama . . . . . . . . . . . . . . . . . . .

PC-2. Structure contour map on top of Smackover Formation in Pace

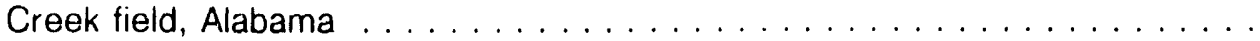

PC-3.

Well log, Mrs. E. V. Pelham 16-2 No. 1 well, Permit No. 5058.

Pace Creek field, Alabama . . . . . . . . . . . . . . . . . . . . . . . 425

PC-4.

Structural cross section of the Pace Creek field, Alabama $\ldots \ldots \ldots \ldots \ldots \ldots$

PC-5.

PCR-1.

Graph of production history of the Pace Creek field, Alabama

426

PCR-2.

Index map of Palmers Crossroads field, Alabama

430

PCR-3.

Structure contour map on top of Smackover Formation in Palmers

Crossroads field, Alabama

Well log, Blacksher 14-11 No. 1 well, Permit No. 5584, Palmers

Crossroads field, Alabama ... . . . . . . . . . . . . . . . . . . . . . 432

PCR. 4 .

Structural cross section of the Palmers Crossroads field, Alabama

433

PCR-5.

Graph of production history of the Palmers Crossroads field, Alabama

434

PCR-6.

Porosity vs. natural log permeability plot for one core, Pairr... -

Crossroads field, Alabama ..........................

PER-1.

Index map of Perdido field, Alabama . . . . . . . . . . . . . . . .

PER-2. Structure contour map on top of Smackover Formation in

Perdido field, Alabama . . . . . . . . . . . . . . . . . . . .

PER-3.

Well log, F. H. Dees 32-11 No. 1 well, Permit No. 3628 ,

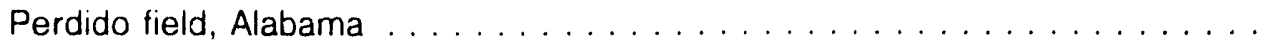

PER-4.

Structural cross section of the Perdido field, Alabama $\ldots \ldots \ldots \ldots \ldots \ldots \ldots$

Graph of production history of the Perdido field, Alabarna . . . . . . . . . . . . 442

PER-5.

PER-6.

Porosity vs. natural log permeability plots, Perdido field, Alabama . . . . . . . .

PER-7.

Detailed core log, Wade Johnson 30-16 well, Permit No. 4696,

Perdido field, Alabama

PER-8. Porosity vs. natural log permeability plot of lithofacies 1 , Wade Johnson

30-16 well, Permit No. 4696, Ferdido field, Alabama . . . . . . . . . . .

PER-9. Paragenetic sequence, Wade Johnson 30-16 well, Permit No. 4696,

Perdido tield, Alabama . . . . . . . . . . . . . . . . . . . . . . . .

PCC-1. Index map of Puss Cuss Creek field, Alabama 


\section{ILLUSTRATIONS-CONTINUED}

Page

PCC-2. Structure contour map on top of Smackover Formation in Puss Cuss

Creek field, Alabama . . . . . . . . . . . . . . . . . .

PCC-3. Well log, M. W. Smith Lumber Co. No. 1 well, Permit No. 2519,

Puss Cuss Creek field, Alabama ...................

PCC-4.

PCC-5.

PCC-6.

Structural cross section of the Puss Cuss Creek field, Alabama . . . . . . . . .

Graph of production history of the Puss Cuss Creek field, Alabama . . . . . . . . .

Porosity vs. natural log permeability plot of one core, Puss Cuss

Creek field, Alabama . . . . . . . . . . . . . . . . . . .

RC-1.

Index map of Red Creek field, Alabama . . . . . . . . . . . . . . . .

RC-2.

RC-3.

$\mathrm{RC}-4$.

RC-5.

RC-6.

RCK-1.

RCK-2.

Structure contour map on top of Smackover Formation in

Red Creek field, Alabama . . . . . . . . . . . . . . . .

4: ?

453

454

455

458

Well log, L. E. Heinmilier No. 1 well, Permit No. 2721, Red Creek

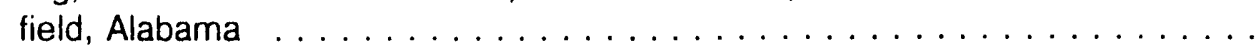

459

460

Structural cross section of the Red Creek field, Alabama $\ldots \ldots \ldots \ldots \ldots \ldots$

Graph of production history of the Red Creek field, Alabama . . . . . . . . . . .

461

462

Porosity vs. natural log permeability plot of two cores combined,

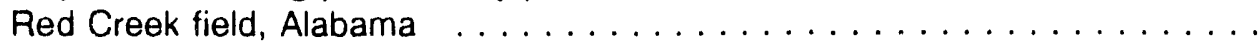

463

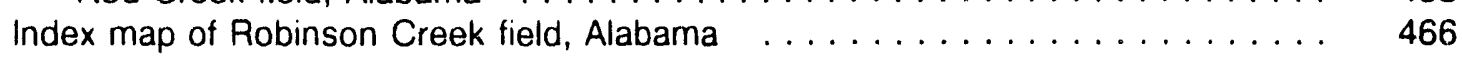

Structure contour map on top of Smackover Formation in Robinson

Creek field, Alabama . . . . . . . . . . . . . . . . . . . . .

467

RCK-3. Well log, A.T.I.C. 17-5 No. 1 well, Permit No. 8835-B, Robinson Creek

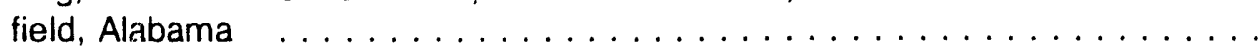

RCK-4.

Structural cross section of the Robinson Creek field, Alabarna . . . . . . . . . .

468

469

RCK-5. Graph of production history of the Robinson Creek field, Alabama . . . . . . . . .

470

Index map of Silas field, Alabama . . . . . . . . . . . . . . . . . 473

SIL-2. Structure contour map on top of Smackover Formation in Silas field, Alabama .............................

Well $\log$ correlated to porosity and permeability, Chesnut unit 4-15 No. 1 well, Permit No. 2084, Silas field, Alabama . . . . . . . .

475

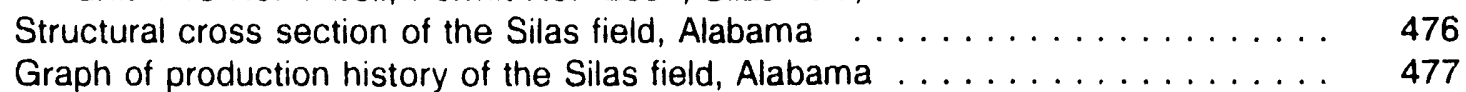

SIL-5.

SIL-6.

SIL-7.

Porosity vs. natural log fermeability plots, Silas field, Alabama . . . . . . . . .

Detailed core log, Chesnut Unit 9-1 No. 1 well, Permit No. 2205, Silas field, Alabama . . . . . . . . . . . . . . . . . . . . . . .

478

SIL-8. Porosity vs. natural log permeability plot for lithofacies 1 , Chesnut Unit 9-1 No. 1 well, Permit No. 2205, Silas field, Alabama . . . . . . . . . .

480

483

SIL-9. Paragenetic sequence, Chesnut Unit 9-1 No. 1 well, Permit No. 2205, Silas field, Alabama . . . . . . . . . . . . . . . . . . . . .

SIL-10. Ternary diagram of pore types, Chesnut Unit 9-1 No. 1 well, Permit

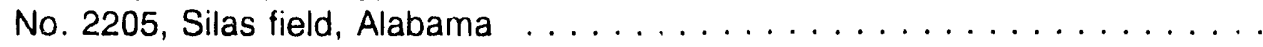

SC-2. Structure contour map on top of Smackover Formation in Sizemore Creek field, Alabama . . . . . . . . . . . . . . . . . . . .

Well log correlated to lithology, A.T.I.C. 33-1 No. 1 well, Permit No. 3988,

Sizemore Creek field, Alabama . . . . . . . . . . . . . . . .

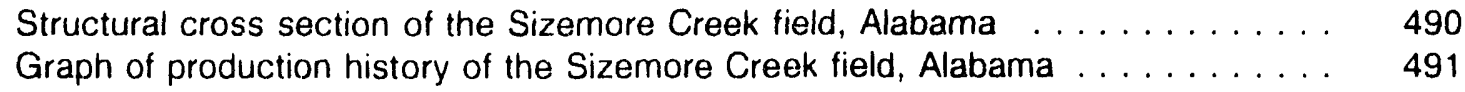

SC-5.

SC-6.

Porosity vs. natural log permeability plot of two cores combined, Sizemore Creek field, Alabama

SC-7.

field, Alabama 


\section{ILLUSTRATIONS-CONTINUED}

Page

SC-8. Paragenetic sequence, A.T.I.C. 33-1 No. 1 well, Permit No. 3988, Sizemore

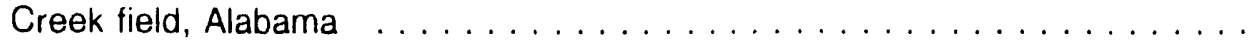

496

$\mathrm{SCH}-1$.

Index map of Smiths Church field, Alabama

$\mathrm{SCH}-2$.

Structure contour map on top of Smackover Formation in Smiths Church

field, Alabama ...........................

498

SCH-3. Well log correlated to lithology, Kelly Unit 2-2 No. 1 well, Fermit No. 5498 ,

Smiths Church field, Alabama . . . . . . . . . . . . . . . . . . . . 500

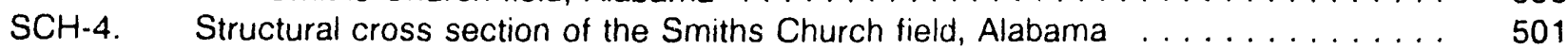

$\mathrm{SCH}-5$. Graph of the production history of the Smiths ?hurch field, Alabama . . . . . . . 502

SBC-1.

SBC-2.

Index map of South Burnt Corn Creek field, Alabama . . . . . . . . . . . . . . . . .

505

SBC-3.

Structure contour map on top of Smackover Formation in South Burnt

Corn Creek field, Alabama . . . . . . . . . . . . . . . . . . . . .

506

Well log, Earl H. Weaver 22-15 No. 1 well, Perınit No. 5272, South Burnt

Corrı Creek field, Alabama . . . . . . . . . . . . . . . . . . . . . .

507

SBC-4.

Structural cross section of the South Burnt Corn Creek field, Alabama . . . . . . . .

508

SBC-5. Graph of prociuction history of the Scuth Burnt Corn Creek

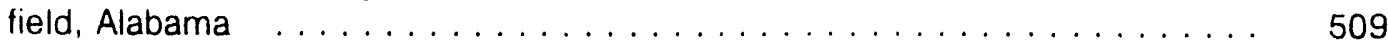

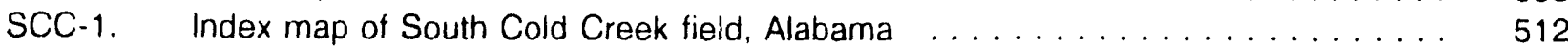

SCC.2. Structure contour map on top of Smackover Formation in South Cold

Creek field, Alabama . . . . . . . . . . . . . . . . . . . . . . . . .

SCC-3. Well log, Mobile County Board of School Commissioners 16-12 No. 1 well,

Permit No. 2071, South Cold Creek field, Alabama . . . . . . . . . . . . . . . 514

SCC-4.

Structural cross section of the South Cold Creek field, Alabama . . . . . . . . . . . .

515

SCC-5.

Graph of production history of the South Cold Creek field, Alabama . . . . . . . . .

516

SCC-6. Porosity vs. natural log permeability plot of one core, South Cold Creek

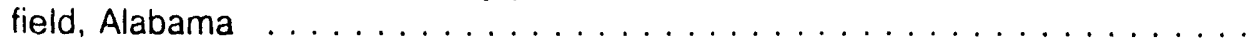

517

SV-1.

Index map of South Vocation field, Alabama

520

SV-2.

Structure contour map on top of Smackover Formation in South

Vocation field, Alabama . . . . . . . . . . . . . . . . . . . . .

SV-3. Well log, Container Corporation 34-16 No. 1 A well, Permit No. 4225,

South Vocation field, Alabama . . . . . . . . . . . . . . . . . . . . . 522

SV-4.

SV-5.

Structural cross section of the South Vocation field, Alabama . . . . . . . . . . .

523

Graph of production history of the South Vocation field, Alabama . . . . . . . . .

Porosity vs. natural log permeability plot of one core, South Vocation

field, Alabama . . . . . . . . . . . . . . . . . . . . . . . . .

524

SV-6.

SWF-1.

Index map of South Wild Fork Creek field, Alabama . . . . . . . . . . . . . . . .

525

SWF-2.

Structure contour map on top of Smackover Formation in South Wild Fork Creek field, Alabama

SWF-3.

Well log, Huxford Estate 8-4 No. 1 well, Permit No. 5869, South Wild Fork

Creek field, Alabama . . . . . . . . . . . . . . . . . . . . .

529

SWF-4.

Structural cross section of the South Wild Fork Creek field, Alabama

530

SWF-5.

Graph of production history of the South Wild Fork

Creek field, Alabama

531

SWH-1.

Index map of South Womack Hil field, Alabama $\ldots \ldots \ldots \ldots \ldots \ldots$

532

SWH-2.

SWH-3.

Structure contour map on top of Smackover Formation in South Womack

Hill field, Alabama

535

Well $\log$, Womack Hill Unit 14-5 No. 1 well, Permit No. 4335-B, South

Womack Hill field, Alabama

SWH.4.

Structural cross section of the South Womack Hill field, Alabama . . . . . . . . . .

SEC-1.

Index map of Southeast Chatom field, Alabama

539

542 


\section{ILLUSTRATIONS-CONTINUED}

Page

SEC-2. Structure contour map on top of Smackover Formation in Southeast

Chatom field, Alabama . . . . . . . . . . . . . . . . . .

543

Well log, Scott "A" 33-1 No. 1 well, Permit No. 5100, Southeast

Chatom field, Alabama . . . . . . . . . . . . . . . . . . . . . .

544

545

546

SEC-5.

Structural cross section of the Southeast Chatom field, Alabama . . . . . . . .

Graph of production history of the Southeast Chatom field, Alabama

Porosity vs. natural log permeability plot of two cores combined,

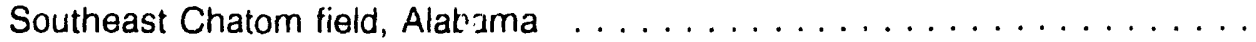

547

550

Index map of Southwest Barrytown field, Alabama . . . . . . . . . .
Structure contour map on top of Smackover Formation in Southwest

Barrytown field, Alabama

551

SWB-3. Well log, Choctaw Land 16-7 No. 1 well, Permit No. 4750, Southwest

Barrytown field, Alabama . . . . . . . . . . . . . . . . . . .

SWB-4.

Structural cross section of the Southwest Barrytown field, Alabama

552

$5 \circ 3$

SWB-5.

Graph of production history of the Southwest Barrytown

field, Alabama

SWB-6.

Porosity vs. natural log permeability plot of two cores combined,

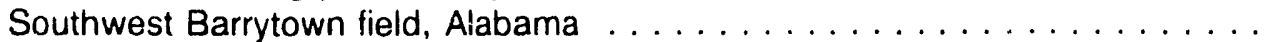

554

555

558

SOU-1.

Index map of Souwilpa Creek field, Alabama . . . . . . . . . . . . . . .

Structure contour map on top of Smackover Formation in Souwilpa

Creek field, Alabama . . . . . . . . . . . . . . . . . . .

SOU-3. Well log, Pinkerton 8-9 No. 1 well, Permit No. 2731, Souwilpa Creek

field, Alabama . . . . . . . . . . . . . . . . . . . . . .

SOU-4.

SOU-5.

STV-1.

STV-2.

Structural cross section of the Souwilpa Creek field, Alabarna . . . . . . . . . . .

Graph of production history of the Souwilpa Creek field, Alabama . . . . . . . . . . .

Index map of Stave Creek field, Alabama . . . . . . . . . . . . . . . . .

Structure contour map on top of Smackover Formation in Stave

Creek field, Alabama . . . . . . . . . . . . . . . . . . .

STV-3. Well log correlated to lithology, porosity, and permeability, McCorquodale

25-1 No. 1 well, Permit No. 2718, Stave Creek field, Alabama . . . . . . . .

STV-A

STV-5.

STV-6.

STV-7.

Structural cross section of the Stave Creek field, Alabama . . . . . . . . . . .

Graph of production history of the Stave Creek field, Alabama . . . . . . . . . .

Porosity vs. natural log permeability plots, Stave Creek field, Alabama . . . . . . . .

Detailed core log, McCorquodale 25-1 No. 1 well, Permit No. 2718,

Stave Creek field, Alabama

STV-8.

Porosity vs. natural log permeability plot for one lithofacies, McCorquodale

25-1 No. 1 well, Permit No. 2718, Stave Creek field, Alabama . . . . . . . .

STV-9. Paragenetic sequence, McCorquodale 25-1 No. 1 well, Permit No. 2718,

Stave Creek field, Alabama . . . . . . . . . . . . . . . . .

SUG-1.

Index map of Sugar Ridge field, Alabama . . . . . . . . . . . . . . .

Structure contour map on top of Smackover Formation in Sugar Ridge

field, Alabama

Well log correlated to lithology, porosity, and permeability, Lovett Unit

27-6 No. 1 well, Permit No. 1903, Sugar Ridge field, Alabama . . . . . . . . .

559

560

561

562

565

566

567

568

569

570

572

574

575

577

578

579

580

581

582

Graph of productic $\rightarrow$ history of the Sugar Ridge field, Alabama . . . . . . . . . .

Porosity vs. natu: al log permeability plots, Sugar Ridge field, Alabama . . . . . . . .

Detailed core log, Lovett 27-6 No. 1 well, Permit No. 1903, Sugar Ridge

field, Alabama

584 


\section{ILLUSTRATIONS-CONTINUED}

Page

SUG-8. Porosity vs. natural log permeability plot for lithofacies 1, Lovett 27-6 No. 1 well, Permit No. 1903, Sugar Ridge field, Alabama . . . . . . . . . . . . . .

SUG-9. Paragenetic sequence, Lovett 27-6 No. 1 well, Permit No. 1903, Sugar Ridge field, Alabama $\ldots \ldots \ldots \ldots \ldots \ldots \ldots \ldots \ldots \ldots \ldots$

TOX-1.

Index map of Toxey field, Alabama . . . . . . . . . . . . . . . . .

590

TOX-2. Structure contour map on top of Smackover Formation in Toxey field, Alabama

TOX-3.

Well log, Jimmerson 4-6 well, Permit No. 1464, Toxey field, Alabama . . . . . . . . .

TOX-4.

Structural cross section of the Toxey field, Alabama . . . . . . . . . . . . .

593

Graph of production history of the Toxey field, Alabama . . . . . . . . . . . . . 594

TOX-6.

Porosity vs. natural log permeability plot of described core for Bolinger 3-4 well, Permit No. 1412, Toxey field, Alabama . . . . . . . . . . . .

TOX-7.

Detailed core log, Bolinger No. 13-4 well, Permit No. 1412,

Toxey field, Alabama . . . . . . . . . . . . . . . . . . . . .

TOX-8. Porosity vs. natural log permeability plot for lithofacies 2, Bolinger 3-4 well, Permit No. 1412, Toxey field, Alabama ... . . . . . . . . . . . 600

TOX-9. Paragenetic sequence, Bolinger 3-4 well, Permit No. 1412 , Toxey field, Alabama ... . . . . . . . . . . . . . . . . . . . . . . . . 601

TOX-10. Ternary diagram of pore types, Bolinger $3-4$ well, Permit No. 1412 , Toxey field, Alabama ... . . . . . . . . . . . . . . . . . . . . . 602

TC-1. Index map of Turkey Creek field, Alabama . . . . . . . . . . . . . . . . .

TC-2. Structure contour map on top of Smackover Formation in Turkey Creek

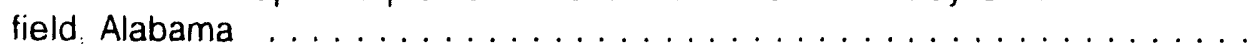

TC-3. Well log, Chesley Pruet-Alco Land \& Timber Co., Inc. No. 1 well, Permit No. 1400 , Turkey Creek field, Alabama . . . . . . . . . . . . . . . . .

TC-6.

Structural cross section of the Turkey Creek field, Alabama . . . . . . . . . . .

Porosity vs. natural log permeability plot for two cores combined, Turkey Creek field, Alabama ... . . . . . . . . . . . . . . . . . . . . 609

TUR-1. Index map of Turnerville field, Alabama . . . . . . . . . . . . . . .

TUR-2. Structure contour map on top of Smackover Formation in Turnerville fisld, Alabama

TUR-3. Well log correlated to lithology, porosity, and permeability, R. J. Newman Jr., et al. 21-11 No. 1 well, Permit No. 4412, Turnerville

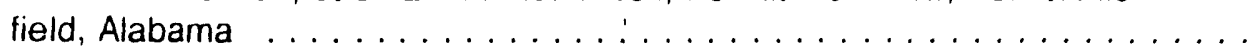

TUR-4. Structural cross section of the Turnerville field, Alabama $\ldots \ldots \ldots \ldots \ldots \ldots$. . . .

TUR-5. Graph of production history of the Turnerville field, Alabama . . . . . . . . . . . TUR-6. Porosity vs. natural log permeability plots, Turnerville field, Alabama . . . . . . . . TUR-7.

Detailed core log, R. J. Newman Jr. et al. 21-11 No. 1, Permit No. 4412 , Turnerville field, Alabama . . . . . . . . . . . . . . . . .

TUR-8.

Porosity vs. natural log permeability plot for lithofacies 1, R. J. Newman Jr. et al. 21-11 No. 1 well, Permit No. 4412, Turnerville field, Alabama . . . . . .

TUR-9.

Paragenetic sequence, R. J. Newman Jr. et al. 21-11 No. 1 well, Permit No. 4412, Turnerville field, Alabama . . . . . . . . . . . . .

URH-1. Index map of Uriah field, Alabama

URH-2. Structure contour map on top of Smackover Formation

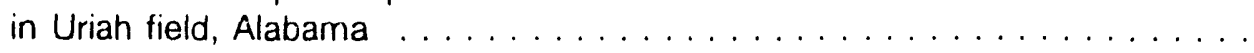

URH-3. Well log, Bibb G. Mims 7-3 No. 1 well, Permit No. 7034 ,

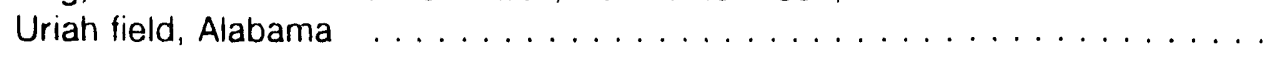




\section{ILLUSTRATIONS-CONTINUED}

Page

628

URH-5. Graph of production history of the Uriah field, Alabama ......
URH-6. Porosity vs. natural log permeability plot of two cores combined,

Uriah field, Alabama . . . . . . . . . . . . . . . . . . .

629

URH-7. Detailed core log, Rufus Garrett 12-7 No. 1, Permit No. 1571, Uriah field, Alabama . . . . . . . . . . . . . . . . . . . . . . . .

URH-8. Paragenetic sequence, Rufus Garrett 12-7 No. 1 well, Permit No. 1571, Uriah field, Alabama

VOC-1. Index map of Vocation field, Alabama . . . . . . . . . . . . . . . Structure contour map on top of Smackover Formation in Vocation field, Alabama ......................

VOC-3.

Well log correlated to lithology, B. C. Quimby $27-15$ No. 1 well, Permit No. 1599, Vocation field, Alabama . . . . . . . . . . . . . . .

Structural cross section of the Vocation field, Alabama . . . . . . . . . . . . .

642

Graph of production history of the Vocation field, Alabama

643

VOC-5.

Porosity vs. natural log permeability plot of one core,

Vocation field, Alabama ......................

644

VOC-7.

Detailed core log, B. C. Quimby 27-15 No. 1 well, Permit No. 1599, Vocation field, Alabama . . . . . . . . . . . . . . . . . . .

VOC-8. Paragenetic sequence, B. C. Quimby 27-15 No. 1 well, Permit No. 1599,

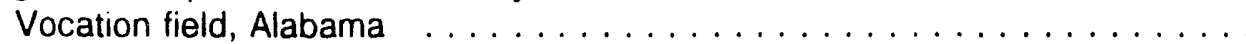

WAL-1. Index map of Wallace field, Alabama ..................... WAL-2.

Structure contour map on top of Smackover Formation in Wallace field, Alabama

646

649

651

652

WAL-3.

Well log, Coastal A.T.I.C. 13-6 No. 1 well, Permit No. 5268,

Wallace field, Alabama .......................

653

654

655

658

WC-1.

Craph of production history of the Wallace field, Alabama

Index map of Wallers Creek field, Alabama

Structure contour map on top of Smackover Formation in Wallers

Creek field, Alabama

659

WC-3.

Well log, Irvin Langford 9-14 No. 3 well, Permit No. 5019, Wallers Creek field, Alabama

WC-4.

WC-5.

WC-6.

WAP-1.

WAP-2.

WAP-3.

Structural cross section of the Wallers Creek field Alabama . . . . . . . . .

Graph of production history of the Wallers Creek fild Alabama ...........

Porosity vs. natural log permeability plot of three cores combined,

Wallers Creek field, Alabama

660

661

662

663

666

Structure contour map on top of Smackover Formation in West Appleton field, Alabama . . . . . . . . . . . . . . . . . . .

667

Well log, P. H. Gallagher 16-3 No. 1 well, Permit No. 5757, West

Appleton field, Alabama . . . . . . . . . . . . . . . . .

668

669

670

673

Graph of production history of the West Appleton field, Alabama . . . . . . . . . .

Index map of West Barrytown field, Alabama . . . . . . . . . . . . . . . .

Structure contour map on top of Smackover Formation in West

Barrytown field, Alabama

674

WBT-3. Well log correlated to porosity and permeability, Abston Unit 10-6

No. 1 well, Permit No. 2148, West Barrytown field, Alabama

675

WBT-4.

Structural cross section of the West Barrytown field, Alabama

676

677 


\section{ILLUSTRATIONS-CONTINUED}

WBT-6. Porosity vs. natural log permeability plots, West Barrytown

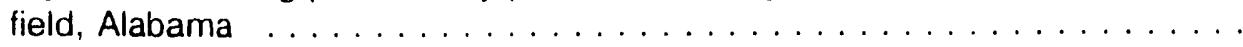

WBT-7. Detailed core log, Lewis Unit 4-16 No. 1, Permit No. 1757, West Barrytown field, Alabama

680

WBT-8. Porosity vs. natural log permeability plot for lithofacies 1, Lewis Unit 4-16 No. 1 well, Permit No. 1757, West Barrytown field, Alabama . . . . . . . . .

WBT-9. Paragenetic sequence, Lewis Unit 4-16 No. 1 well, Permit No. 1757 , West Barrytown field, Alabama .....................

WBD-1. Index map of West Bend field, Alabama

684

WBD-2.

Structure contour map on top of Smackover Formation in West Bend field, Alabama . . . . . . . . . . . . . . . . . . . .

WBD-3.

Well log correlated to lithology, porosity, and permeability, May 27-10 No. 1 well, Permit No. 2647, West Bend field, Alabama . . . . . . . . . . .

WBD-4.

WBD-5.

WBD-6.

WBD-7.

Structural cross section of the West Bend field, Alabama . . . . . . . . . . . . . Graph of production history of the West Bend field, Alabama . . . . . . . . . Porosity vs. natural log permeability plots, West Bend field, Alabama . . . . . . . . Detailed core log, May 27-10 No. 1 well, Permit No. 2647, West Bend field, Alabama

685

687

688

689

690

691

692

694

WBD-8. Porosity vs. natural log permeability plots for two lithofacies, May 27-10 No. 1 well, Permit No. 2647, West Bend field, Alabama . . . . . . . . . . . 697

WBD-9. Paragenetic sequence, May 27-10 No. 1 well, Permit No. 2647, West Bend field, Alabama .......................

698

WOC-1. Index map of West Okatuppa Creek field, Alabama

700

WOC-2. Structure contour map on top of Smackover Formation in West Okatuppa Creek field, Alabama . . . . . . . . . . . . . . . . . . .

WOC-3.

Well log, Land 6-1 No. 1 well, Permit No. 5776-B, West Okatuppa

Creek field, Alabama . . . . . . . . . . . . . . . . . . . . . .

702

WOC-4

Structural cross section of the West Okatuppa Creek field, Alabama . . . . . . . .

703

WOC-5. Graph of production history of the West Okatuppa

Creek field, Alabama

704

WFC-1.

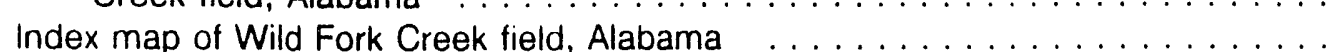

707

WFC-2.

WFC-3.

Structure contour map on top of Smackover Formation in Wild Fork

Creek field, Alabama

708

Well log, I.P.C. 5-10 No. 1 well, Permit No. 5411, Wild Fork Creek

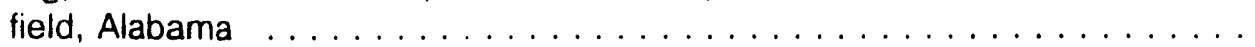

709

WFC-4.

Structural cross section of the Wild Fork Creek field, Alabama . . . . . . . . . .

710

WFC-5.

Graph of production history of the Wild Fork Creek field, Alabama . . . . . . . . .

711

WFC-6.

Porosity vs. natural log permeability plot of one core,

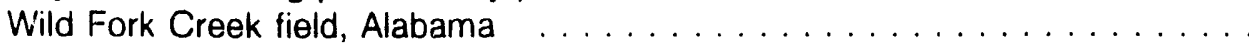

WIM-1.

Index map of Wimberly field, Alabama $\ldots \ldots \ldots \ldots \ldots \ldots \ldots \ldots$

715

WIM-2. Structure contour map on top of Smackover Formation in

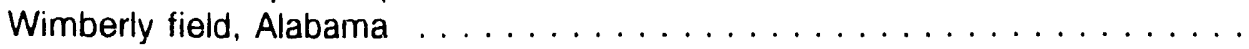

WIM-3. Well log, Bolinger Unit 25-9 No. 1 well, Permit No. 2245,

Wimberly field, Alabama $\ldots \ldots \ldots \ldots \ldots \ldots \ldots \ldots$

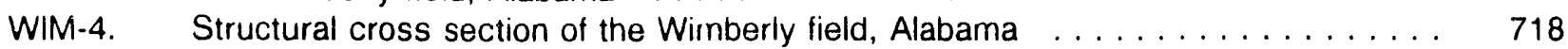

WIM-5. Graph of production history of the Wimberly field, Alabama . . . . . . . . . 719

WIM-6. Porosity vs. natural log permeability plot of three cores combined,

Wimberly field, Alabama ... . . . . . . . . . . . . . . . . . . . . . . . . . . 720

WOM-1. Index map of Womack Hill field, Alabama $\ldots \ldots \ldots \ldots \ldots \ldots$ 


\section{ILLUSTRATIONS-CONTINUED}

WOM-2. Structure contour map on top of Smackover Formation in Womack Hill field, Alabama . . . . . . . . . . . . . . . . . . . . . . . 724

WOM-3. Well log, WHFU; Parker-Locke 9-16 No. 1 well, Permit No. 1655, Womack Hill field, Alabama . . . . . . . . . . . . . . . . . . . . . 725

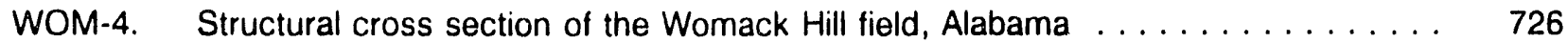

WOM-5. Graph of production history of the Womack Hill field, Alabama . . . . . . . . . . 727

WOM-6. Porosity vs. natural log permeability plot of 38 wells combined, Womack Hill field, Alabama . . . . . . . . . . . . . . . . . . 728

WOM-7. Detailed core log, Turner 13-25 well, Permit No. 2327, Womack Hill field, Alabama . . . . . . . . . . . . . . . . . . . . . . . . 730

WOM-8. Paragenetic sequence, Turner 13-25 well, Permit No. 2327, Womack Hill field, Alabama . . . . . . . . . . . . . . . . . . . . . . . 732

ZC-1. Index map of Zion Chapel field, Alabama $\ldots \ldots \ldots \ldots \ldots \ldots \ldots \ldots$

ZC.2. Structure contour map on top of Smackover Formation in Zion Chapel field, Alabama . . . . . . . . . . . . . . . . . . . 735

ZC-3. Well log correlated to lithology, porosity, and permeability, Federal Land Bank Unit 17.11 No. 1 well, Permit No. 2372, Zion

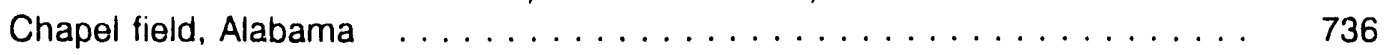

2C.4. Structural cross section of the Zion Chapel field, Alabama . . . . . . . . . . . 737

ZC-5. Graph of production history of the Zion Chapel field, Alabama . . . . . . . . 738

ZC-6. Porosity vs. natural log permeability plots, Zion Chapel field, Alabama . . . . . . 739

ZC-7. Detailed core log, Federal Land Bank No. 1 well, Permit No. 2372, Zion Chapel field, Alabama ... . . . . . . . . . . . . . . . . . . . 741

ZC-8. Porosity vs. log permeability plot for lithofacies 1, Federal Land Bank No. 1 well, Permit No. 2372, Zion Chapel field, Alabama . . . . . . . . . . . . 743

ZC-9. Paragenetic sequence, Federal Land Bank Unit 17-11 No. 1 well, Permit No. 2372, Zion Chapel field, Alabama . . . . . . . . . . . . . . . . . . 744

ZC-10. Ternary diagram of pore types, Federal Land Bank No. 1 well, Permit No. 2372, Zion Chapel field, Alabama . . . . . . . . . . . . . . . 745 


\section{TABLES}

APT-1. Reservoir characterization sheet, Smackover pool, Appleton field,

Escambia County, Alabama .........................

APT-2. Lithofacies description of core from D. W. McMillan 2-15 No. 5 well,

Permit No. 6247, Appleton field, Alabama . . . . . . . . . . . . . . . . 10

BAR-1. Reservoir characterization sheet, Smackover pool, Barnett field, Conecuh

and Escambia Counties, Alabama . . . . . . . . . . . . . . .

BAR-2. Lithofacies description of core from Alger Sullivan "C" No. 1 well,

Permit No. 1827-A, Barnett field, Alabama . . . . . . . . . . . . . . . . . .

BB-1. Reservoir characterization sheet, Smackover pool, Barlow Bend field,

Clarke and Monroe Counties, Alabama . . . . . . . . . . . . . . .

BTN-1. Reservoir characterization sheet, Smackover pool, Barrytown field,

Choctaw County, Alabama . . . . . . . . . . . . . . . . . . .

19

21

32

40

BTN-2. Lithofacies description of core from Mclllwain 11-10 No. 1 well,

Permit No. 1818, Barrytown field, Alabama . . . . . . . . . . . . .

BEC-1. Feservoir characterization sheet, Smackover pool, Big Escambia

Creek field, Escambia County, Alabama . . . . . . . . . . . . . . .

BEC-2. Lithofacies description of core from Srnith 25-7 No. 1 well, Permit No. 4727,

Big Escambia Creek field, Alabama . . . . . . . . . . . . . . . . .

BLS-1. Reservoir characterization sheet, Smackover pool, Blacksher field,

Baldwin County, Alabama . . . . . . . . . . . . . . . . . .

BLS-2. Lithofacies description of core from International Paper Co. 20-5 No. 1 well,

Permit No. 5242, Blacksher field, Alabama . . . . . . . . . . . . . . . .

BLC-1. Reservoir characterization sheet, Smackover pool, Broken Leg Creek field,

Escambia County, Alabama ... . . . . . . . . . . . . . . . . .

BUC-1.

Reservoir characterization sheet, Smackover pool, Bucatunna Creek field,

Choctaw County, Alabama . . . . . . . . . . . . . . . . . . .

BUC-2. Lithofacies description of core from Johnson Unit 14-14 No. 1 well,

Permit No. 2753, Bucatunna Creek field, Alabama . . . . . . . . . . . . . . .

BCC-1. Reservoir characterization sheet, Smackover pool, Burnt Corn Creek field,

Escambia County, Alabama .......................

BCC-2. Lithofacies description of core from Hooper Mathews 4-8 No. 1 well,

Permit No. 2377, Burnt Corn Creek field, Alabama . . . . . . . . . . . . . . .

$\mathrm{CH}-1$. Reservoir characterization sheet, Smackover pool, Chappell Hill field,

Choctaw County, Alabama . . . . . . . . . . . . . . . . . . . . . . .

$\mathrm{CH}$-2. Lithofacies description of core from Bolinger 26-7 No. 1 well, Permit No. 2426,

Chappell Hill field, Alabama $\ldots \ldots \ldots \ldots \ldots \ldots \ldots \ldots$. . . . . . . . . . .

CTM-1. Reservoir characterization sheet, Smackover pool, Chatom field, Washington

County, Alabama . . . . . . . . . . . . . . . . . . . . .

CTM-2. Lithofacies description of core from Chatom Unit 20-14 No. 1-04 well,

Permit No. 7044, Chatom field, Alabama . . . . . . . . . . . . . . . . . .

CHR-1. Reservoir characterization sheet, Smackover pool, Choctaw Ridge field,

Choctaw County, Alabama . . . . . . . . . . . . . . . . . . . . . .

CHR-2. Lithofacies description of core from Rentz-Trice Unit 35-1 No. 5 well,

Permit No. 1427, Choctaw Ridge field, Alabama . . . . . . . . . . . . . . 143

CHU-1. Reservoir characterization sheet, Smackover pool, Chunchula field, Mobile

County, Alabama . . . . . . . . . . . . . . . . . . . . .

CHU-2. Lithofacies description of core from Annie M. Hill et al. 10-10 No. 1 well,

Permit No. 2218, Chunchula field, Alabama . . . . . . . . . . . . . . . .

CC-1.

Reservoir characterization sheet, Smackover pool, Cold Creek field,

Mobile County, Alabama 


\section{TABLES-CONTINUED}

CPL-1. Reservoir characterization sheet, Smackover pool, Copeland field, Washington County, Alabama . . . . . . . . . . . . . . . . . . . .

CRC-1. Reservoir characterization sheet, Smackover pool, Crosbys Creek field, Washington County, Alabama . . . . . . . . . . . . . . . . . . .

CRC-2. Lithofacies description of core from Darly Dees 3-3 No. 1 well,

Permit No. 5115, Crosbys Creek field, Alabama . . . . . . . . . . . . . . .

EB-1. Reservoir characterization sheet, Smackover pool, East Barnett field, Conecuh County, Alabama . . . . . . . . . . . . . . . . . . .

EB-2. Lithofacies description of core from Scott Paper Co. 1-1 No. 1 well, Permit No. 5740, East Barnett field, Alabama . . . . . . . . . . . . . . . . .

EH-1. Reservoir characterization sheet, Smackover pool, East Huxford field, Escambia County, Alabama . . . . . . . . . . . . . . . . . . .

FC-1.

Reservoir characterization sheet, Smackover pool, Fanny Church field, Escambia County, Alabama . . . . . . . . . . . . . . . . . . . .

GC-1. Reservoir characterization sheet, Smackover pool, Gin Creek field, Choctaw County, Alabama . . . . . . . . . . . . . . . . . .

GC-2.

Lithofacies description of core from Bolinger Heirs 32-5 No. 1 well, Permit

No. 3312, Gin Creek field, Alabama . . . . . . . . . . . . . . . . .

GUC-1. Reservoir characterization sheet, Smackover pool, Gulf Crest field,

Choctaw County, Alabama . . . . . . . . . . . . . . . . . . . . 230

HC-1. Reservoir characterization sheet, Smackover pool, Hanberry Church field, Escambia County, Alabama . . . . . . . . . . . . . . . .

HP-1. Reservoir characterization sheet, Smackover pool, Hatter's Pond field,

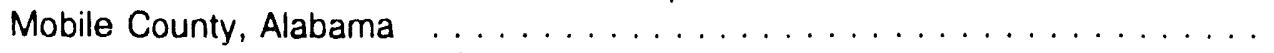

HP-2. Lithofacies description of core from Hatter's Pond Unit 10-3 No. 1 well, Permit No. 6846, Hatter's Pond field, Alabama . . . . . . . . . . . . .

HS-1. Reservoir characterization sheet, Smackover pool, Healing Springs field, Washington County, Alabama . . . . . . . . . . . . . . .

HS-2. Lithofacies description of core from W. J. Britton No. 1 well, Permit No. 2478, Healing Springs field, Alabama ... . . . . . . . . . . . 260

HUX-1. Reservoir characterization sheet, Smackover pool, Huxford field, Escambia County, Alabama . . . . . . . . . . . . . . . . . .

HUX-2. Lithofacies description of core from M. H. Murphy $26-11$ No. 1 well, Permit No. 4577, Huxford field, Alabama ..................

LEC-1. Reservoir characterization sheet, Smackover pool, Little Escambia Creek field, Escambia County, Alabama . . . . . . . . . . . . . . . .

LEC-2. Lithofacies description of core from T. R. Miller Mill Unit 32-3 well, Permit No. 1654, Little Escambia Creek field, Alabama . . . . . . . . . . . . . . . .

LMC-1. Reservoir characterization sheet, Smackover pool, Little Mill Creek field, Choctaw County, Alabama . . . . . . . . . . . . . . . . . .

LR-1. Reservoir characterization sheet, Smackover pool, Little River field,

Baldwin County, Alabama . . . . . . . . . . . . . . . . . .

LR-2. Lithofacies description of core from J. E. Robinson et al. 11-8 No. 1 well,

Permit No. 3046, Little River field, Alabama . . . . . . . . . . . . . . . .

LRK-1. Reservoir characterization sheet, Smackover pool, Little Rock field,

Escambia County, Alabama . . . . . . . . . . . . . . . . . .

LOV-1. Reservoir characterization sheet, Smackover pool, Lovetts Creek field, Baldwin and Monroe Counties, Alabama . . . . . . . . . . . . .

LOV-2. Lithofacies description of core from W. M. Threat 11-10 No. 1 well, Permit No. 3535, Lovetts Creek field, Alabama . . . . . . . . . . . . . . 


\section{TABLES-CONTINUED}

Page

MEL-1. Reservoir characterization sheet, Smackover pool, Melvin field,

Choctaw County, Alabama . . . . . . . . . . . . . . . . . . . . . . . 347

MC-1. Reservoir characterization sheet, Smackover pool, Mill Creek field,

Choctaw County, Alabama . . . . . . . . . . . . . . . . . . . . 355

MIN-1. Reservoir characterization sheet, Smackover pool, Mineola field,

Monroe County, Alabama . . . . . . . . . . . . . . . . . . . . . 362

MOV-1. Reservoir characterization sheet, Smackover pool, Movico field, Baldwin

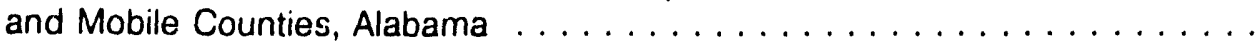

MOV-2. Lithofacies description of core from Sullivan et al. No. 1 well, Permit

No. 2126, Movico field, Alabama . . . . . . . . . . . . . . . . .

NCR-1. Reservoir characterization sheet, Smackover pool, North Choctaw

Ridge field, Choctaw County, Alabama ...................

NCR-2. Lithofacies description of core from Oates Unit 29-6 No. 1 well, Permit

No. 1878, North Choctaw Ridge field, Alabama . . . . . . . . . . . . .

NSC-1. Reservoir characterization sheet, Smackover pool, North Smiths

Church field, Escambia County, Alabama . . . . . . . . . . . . . . .

NWC-1. Reservoir characterization sheet, Smackover pool, North Wallers Creek field, Monroe County, Alabama . . . . . . . . . . . . . . . . . . . 402

NWC-2. Lithofacies description of core from Irvin Langford 5-10 No. 1 well, Permit No. 7589, North Wallers Creek field, Alabama ... . . . . . . . . . . . . 404

NEB-1. Reservoir characterization sheet, Smackover pool, Northeast Barnett field, Conecuh County, Alabama . . . . . . . . . . . . . . .

NWR-1. Reservoir characterization sheet, Smackover pool, Northwest Range field, Conecuh County, Alabama . . . . . . . . . . . . . . . .

Reservoir characterization sheet, Smackover pool, Pace Creek field,

PC-1. Clarke County, Alabama

PCR-1.

Reservoir characterization sheet, Smackover pool, Palmers Crossroads field, Monroe and Clarke Counties, Alabama .................

PER-1. Reservoir characterization sheet, Smackover pool, Perdido field, Baldwin and Escambia Counties, Alabama ................

PER-2. Lithofacies description of core from Wade Johnson 30-16 well, Permit No. 4696, Perdido field, Alabama . . . . . . . . . . . . . . . . . .

PCC-1. Reservoir characterization sheet, Smackover pool, Puss Cuss Creek field, Choctaw County, Alabama . . . . . . . . . . . . . . . . . . . . .

RC-1. Reservoir characterization sheet, Smackover pool, Red Creek field, Washington County, Alabama . . . . . . . . . . . . . . . . .

RCK-1. Reservoir characterization sheet, Smackover pool, Robinson Creek field, Escambia County, Alabama ...................

SIL-1. Reservoir characterization sheet, Smackover pool, Silas field, Choctaw County, Alabama .........................

SIL-2. Lithofacies description of core from Chesnut Unit $9-1$ No. 1 well, Permit No. 2205, Silas field, Alabama . . . . . . . . . . . . . .

SC-1. Reservoir characterization sheet, Smackover pool, Sizemore Creek

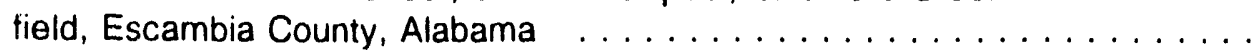

SC-2. Lithofacies description of core from A.T.I.C. 33-1 No. 1 well, Permit No. 3988 , Sizemore Creek field, Alabama . . . . . . . . . . . . . . . . .

$\mathrm{SCH}$-1. Reservoir characterization sheet, Smackover pool, Smiths Church field, Escambia County, Alabama . . . . . . . . . . . . . . . .

SBC-1. Reservoir characterization sheet, Smackover pool, South Burnt Corn Creek field, Escambia County, Alabama . . . . . . . . . . . . . 


\section{TABLES-CONTINUED}

SCC-1. Reservoir characterization sheet, Smackover pool, South Cold Creek field, Mobile County, Alabama ........................

SV-1. Reservoir characterization sheet, Smackover pool, South Vocation field, Monroe County, Alabama ... . . . . . . . . . . . . . . . . . 526

SWF-1. Reservoir characterization sheet, Smackover pool, South Wild Fork Creek field, Escambia County, Alabama . . . . . . . . . . . . . . . . .

SWH-1. Reservoir characterization sheet, Smackover pool, South Womack Hill field, Clarke County, Alabama . . . . . . . . . . . . . . . . . .

SEC-1. Reservoir characterization sheet, Smackover pool, Southeast Chatom field, Washington County, Alabama . . . . . . . . . . . . . . . .

SWB-1. Reservoir characterization sheet, Smackover pool, Southwest Barrytown field, Choctaw County, Alabama . . . . . . . . . . . . . . . .

SOU-1. Reservoir characterization sheet, Smackover pool, Souwilpa Creek

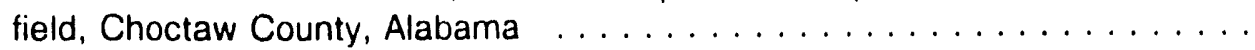

STV-1. Reservoir characterization sheet, Smackover pool, Stave Creek field, Clarke County, Alabama . . . . . . . . . . . . . . . . . . . .

STV-2. Lithofacies description of core from McCorquodale 25-1 No. 1 well, Permit No. 2718, Stave Creek field, Alabama . . . . . . . . . . . . . . .

SUG-1. Reservoir characterization sheet, Smackover pool, Sugar Ridge field, Choctaw County, Alabama ......................

SUG-2. Lithofacies description of core from Lovett 27.6 No. 1 well, Permit No. 1903, Sugar Ridge field, Alabama . . . . . . . . . . . . . . . . .

TOX-1. Reservoir characterization sheet, Smackover pool, Toxey field, Choctaw

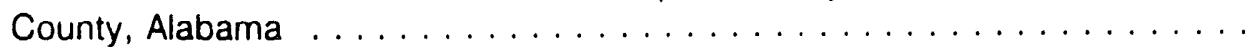

TOX-2. Lithofacies description of core from Bolinger 3-4 well, Permit No. 1412, Toxey field, Alabama . . . . . . . . . . . . . . . . . . . .

TC-1.

Reservoir characterization sheet, Smackover pool, Turkey Creek field, Choctaw County, Alabama . . . . . . . . . . . . . . . . . .

TUR-1. Reservoir characterization sheet, Smackover pool, Turnerville field, Mobile County, Alabama ....................... 618

TUR-2. Lithofacies description of core from R. J. Newman et al. 21.11 No. 1 well, Permit No. 4412, Turnerville field, Alabama ... . . . . . . . . . . . . . 620

URH-1. Reservoir characterization sheet, Smackover pool, Uriah field, Monroe County, Alabama ... . . . . . . . . . . . . . . . . . . 630

URH-2. Lithofacies description of core from Rufus Garrett 12.7 No. 1 well, Permit No. 1571, Uriah field, Alabama . . . . . . . . . . . . . . . .

VOC-1. Reservoir characterization sheet Smackover pool, Vocation field, Monroe County, Alabama . . . . . . . . . . . . . . . . .

VOC-2. Lithofacies description of core from B. C. Quimby 27-15 No. 1 well, Permit No. 1599, Vocation field, Alabama . . . . . . . . . . . . .

WAL-1. Reservoir characterization sheet, Smackover pool, Wallace field, Escambia County, Alabama . . . . . . . . . . . . . . . . . . 656

WC-1. Reservoir characterization sheet, Smackover pool, Wallers Creek field, Monroe County, Alabama ... . . . . . . . . . . . . . . . . . . . . 664

WAP-1. Reservoir characterization sheet, Smackover pool, West Appleton field, Escambia County, Alabama ......................

WBT-1. Reservoir characterization sheet, Smackover pool, West Barrytown

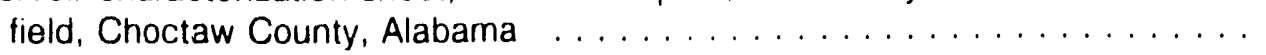

WBT-2. Lithofacies description of core from Lewis Unit 4-16 No. 1 well, Permit No. 1757, West Barrytown field, Alabama . . . . . . . . . . . . . 


\section{TABLES-CONTINUED}

WBD-1. Reservoir characterization sheet, Smackover pool, West Bend field, Clarke County, Alabama . . . . . . . . . . . . . . . . . . . . . . 693

WBD-2. Lithofacies description of core from May 27-10 No. 1 well, Permit No. 2647, West Bend field, Alabama . . . . . . . . . . . . . . . . . . . . . . . 695

WOC-1. Reservoir characterization sheet, Smackover pool, West Okatuppa Creek field, Choctaw County, Alabama ... . . . . . . . . . . . . . . 705

WFC-1. Reservoir characterization sheet, Smackover pool, Wild Fork Creek field, Escambia County, Alabama ... . . . . . . . . . . . . . . 713

WIM-1. Reservoir characterization sheet, Smackover pool, Wimberly field, Choctaw County, Alabama ... . . . . . . . . . . . . . . . . . . . . . . 721

WOM-1. Reservoir characterization sheet, Smackover pool, Womack Hill field, Choctaw and Clarke Counties, Alabama . . . . . . . . . . . . . . . . . . 729

WOM-2. Lithofacies description of core from Turner 13-25 well, Permit No. 2327, Womack Hill field, Alabama . . . . . . . . . . . . . . . . . . . . 731

ZC-1. Reservoir iharacterization sheet, Smackover pool, Zion Chapel field, Choctaw County, Alabama . . . . . . . . . . . . . . . . . . . . . . . . 740

ZC-2. Lithofacies description of core from Federal Land Bank Unit 17-11 No. 1 well, Permit No. 2372, Zion Chapel field, Alabama 


\section{Field codes for Smackover oil fields in southwest Alabama}

\begin{tabular}{|c|c|c|c|}
\hline FIELD CODE & FIELD NAME & FIELD CODE & FIELD NAME \\
\hline APP & Appleton field & NEB & Northheast Barnett field \\
\hline $\mathrm{BB}$ & Barlow Bend field & NWR & Northwest Range field \\
\hline BAR & Barnett fieid & PC & Pace Creek field \\
\hline BTN & Barrytown field & PCR & Palmers Crossroads field \\
\hline BEC & Big Escambia Creek field & PER & Perdido field \\
\hline BLS & Blacksher field & PCC & Puss Cuss Creek field \\
\hline BLC & Broken Leg Creek field & $\mathrm{RC}$ & Red Creek field \\
\hline$B \cup C$ & Bucatunna Creek field & RCK & Robinsons Creek field \\
\hline $\mathrm{BCC}$ & Burnt Corn Creek field & SIL & Silas field \\
\hline $\mathrm{CH}$ & Chappell Hill field & SC & Sizemore Creek field \\
\hline CTM & Chatom field & $\mathrm{SCH}$ & Smiths Church \\
\hline $\mathrm{CHR}$ & Choctaw Ridge field & SBC & South Burnt Corn Creek field \\
\hline $\mathrm{CHU}$ & Chunchula field & SCC & South Cold Creek field \\
\hline $\mathrm{CC}$ & Cold Creek field & SV & South Vocation field \\
\hline CPL & Copeland Gas field & SWF & South Wild Fork Creek field \\
\hline CAC & Crosby Creek field & SWH & South Womack Hill field \\
\hline EB & East Barnett field & SEC & Southeast Chatom field \\
\hline $\mathrm{EH}$ & East Huxford field & SWB & Southwest Barrytown field \\
\hline FC & Fanny Church field & SOU & Souwilpa Creek field \\
\hline GC & Gin Creek field & STV & Stave Creek field \\
\hline GUC & Gulf Crest field & SUG & Sugar Ridge field \\
\hline $\mathrm{HC}$ & Hanberry Church field & TOX & Toxey field \\
\hline HP & Hatter's Pond field & $\mathrm{TC}$ & Turkey Creek field \\
\hline HS & Healing Springs field & TUR & Turnerville field \\
\hline HUX & Huxford field & URH & Uriah field \\
\hline LEC & Little Escambia Creek field & VOC & Vocation field \\
\hline LMC & Little Mill Creek field & WAL & Wallace field \\
\hline LR & Little River field & WC & Wallers Creek field \\
\hline LRK & Little Rock field & WAP & West Appleton field \\
\hline LOV & Lovetts Creek field & WBT & West Barrytown field \\
\hline MEL & Melvin field & WBD & West Bend field \\
\hline MC & Mill Creek field & WOC & West Okatuppa Creek field \\
\hline MIN & Mineola field & WFC & Wild Fork Creek field \\
\hline MOV & Movico field & WIM & Wimberly field \\
\hline NCR & North Choctaw Ridge field & WOM & Womack Hill field \\
\hline NSC & North Smiths Church field & $2 \mathrm{C}$ & Zion Chapel field \\
\hline NWC & North Wallers Creek field & & \\
\hline
\end{tabular}




\section{WELL SYMBOLS}

DRILLING OR LOCATION

SHUT-IN OR TEMPORARILY ABANDONED WELL

- Plugged rivd ABANDONED WELL

$\Upsilon_{\text {SWO }}$ SALT WATER DISPOSAL WELL

$O_{E R}$ ENHANCED RECOVERY WELL

C OIL WELL

SHUT-IN OR TEMPORARILY ABANDONED OIL V'ELL

Plugged and abANDONed OIL WELL

$\int_{5 w 0}$

OIL WELL CONVERTED TO SALT WATER DISPOSAL WELL

OIL WVELL CONVERTED TO ENHANCED RECOVERY WELL

CORE DESCRIBED

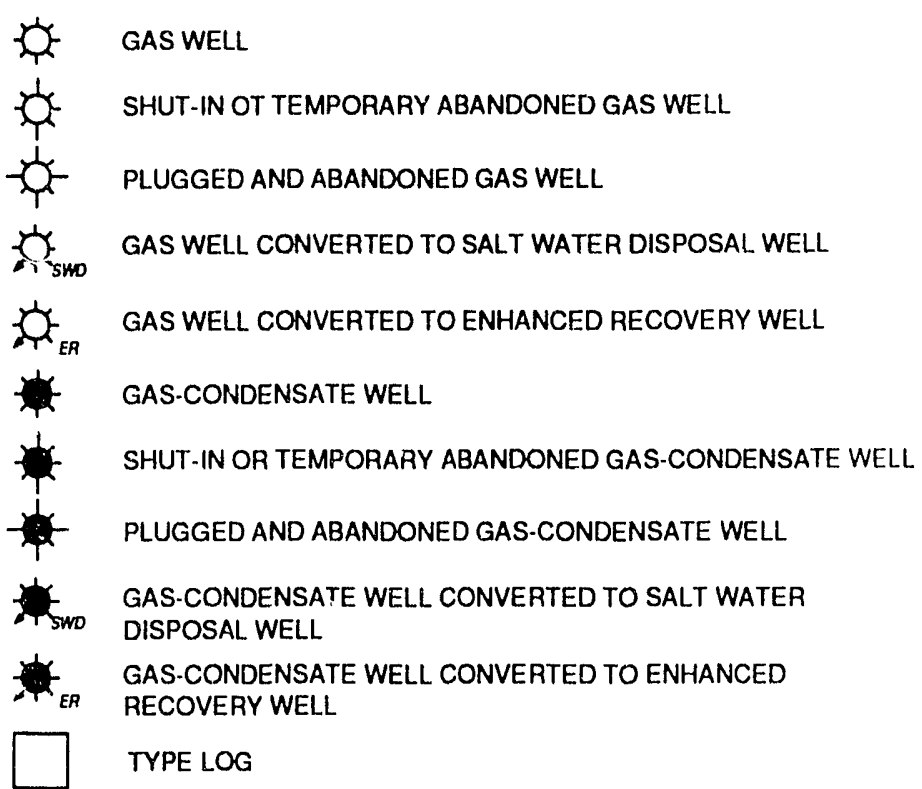

\section{STRUCTURE MAPS}

SL PERMITTED SURFACE LOCATION

BHL WELL BOTTOM HOLE LOCATION

T4N TOWNSHIP 4 NOATH

RGE RANGE GEAST

13 SECTION 13 (GENERALLY NUMBERED 1 THROUGH 36: IRRE GULAR SECTION NUMBERS MAY EXCEED 36)

1784 STATE PERMIT NURABER; USED FOR WELL ICENTIFICATION

7354-A PERMITTED WELL RE-ENTRY AFTER SUSPENSION OF INITIAL OPERATIONS

2.53-B WELL PERMITTED TO BE DIRECTIONALLY DRILLED

- - GWC - . - GASWATER CONTACT

- - HKW - - HIGHEST K.NOWN WATER

_. - LKG _. - LOWEST KNOWN GAS

- - LKO - - LOWEST KNOWN OIl.

- . - OWC - . - OILWATER CONTACT

$-\infty-$ FIELD 3OUNDRY

$-\infty-$ COUNTY BOUNDRY

STATF BOUNDRY

$A \longrightarrow A^{\prime}$ LINE OF CROSS SECTION

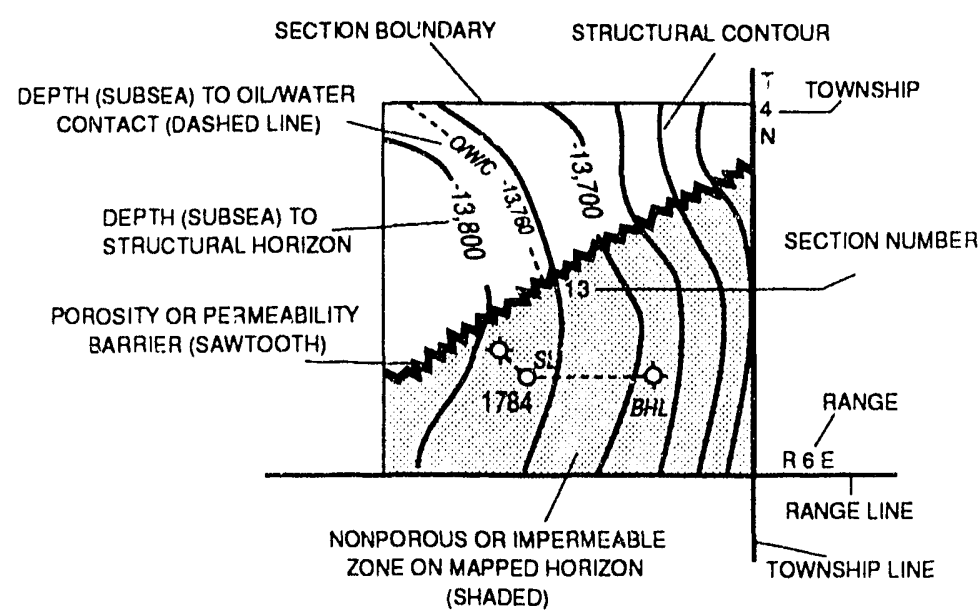

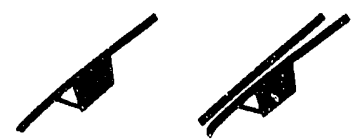

NORMAL FAULTS
TOOTH ON DOWNTHROWN SIDE OF FAULT: WIDTH BETWEEN UPTHROWN LINE AND DOWNTHROWN LINE PROPORATIONAL TO AMOUNT OF "MISSING" SECTION AND ASSOCIATED VERTICAL DISPLACEMENT ALONG FAILT PLANE. 


\section{KEY TO CORE LOGS}

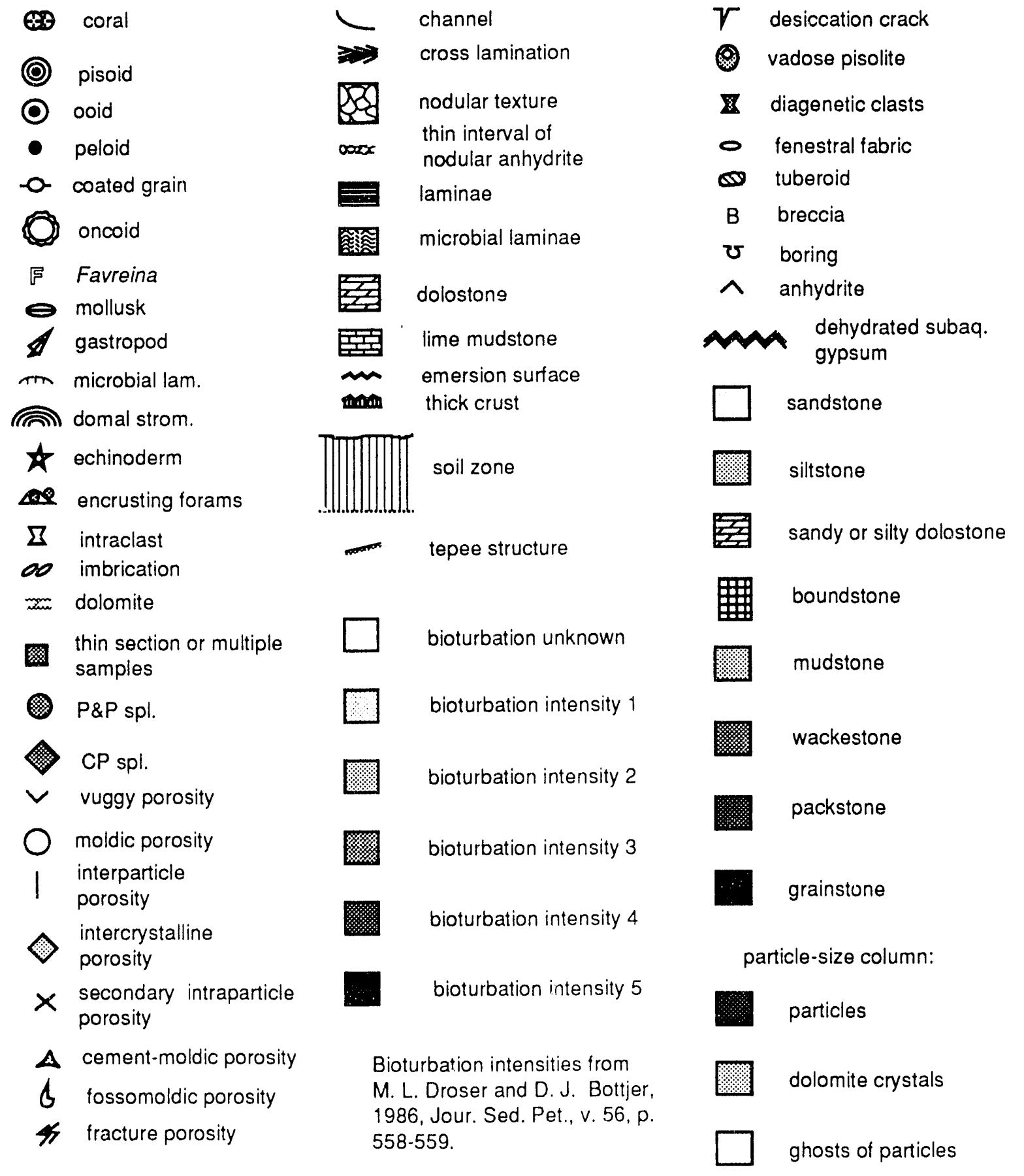




\section{ABBREVIATIONS}

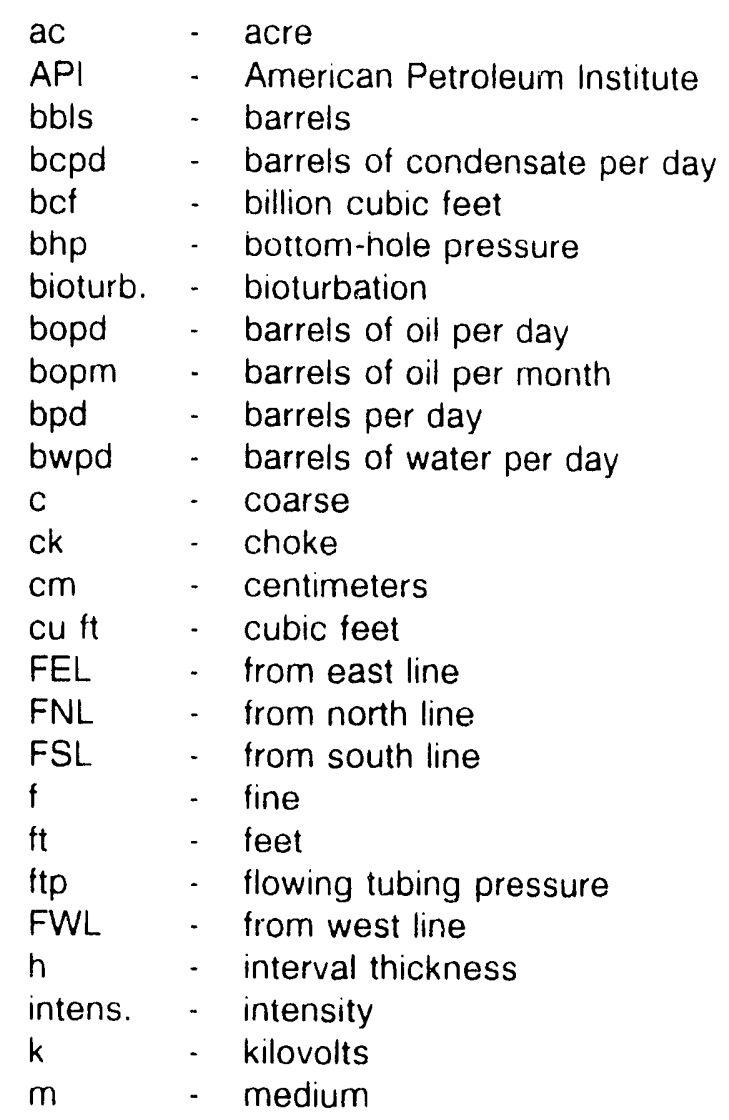

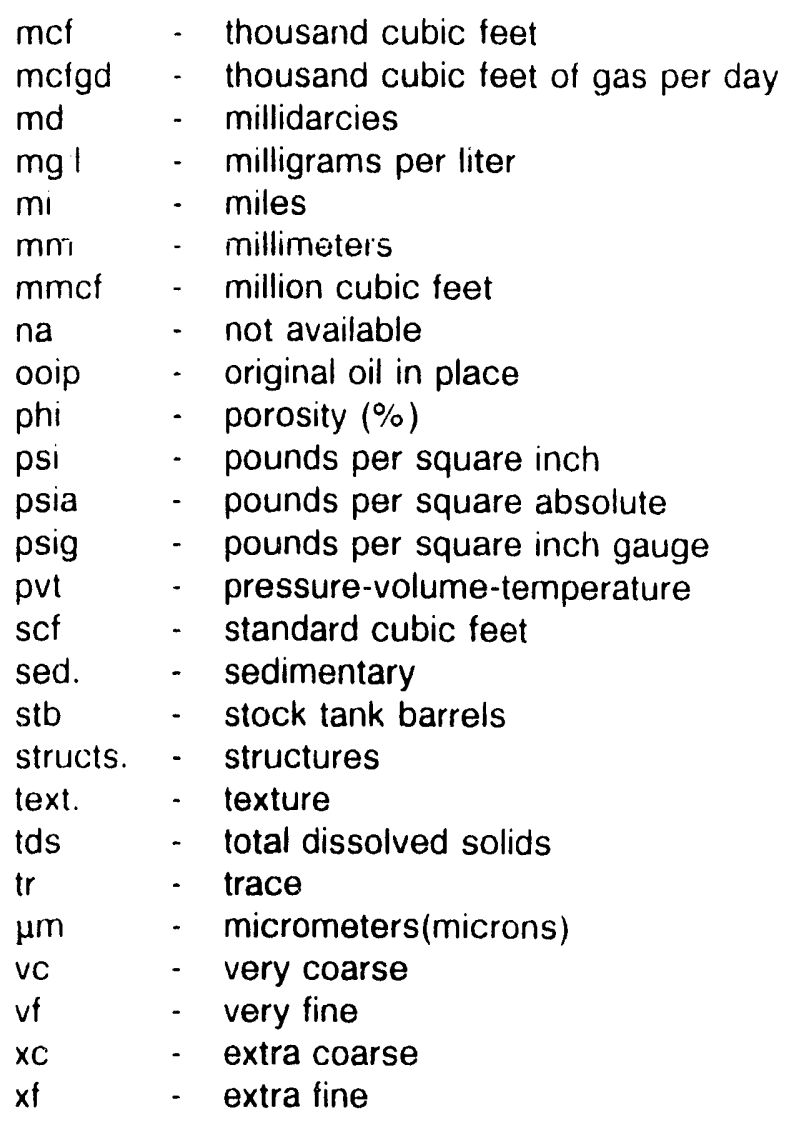




\section{APPLETON FIELD}

\section{SMACKOVER OIL POOL}

\section{ESCAMBIA COUNTY, ALABAMA}




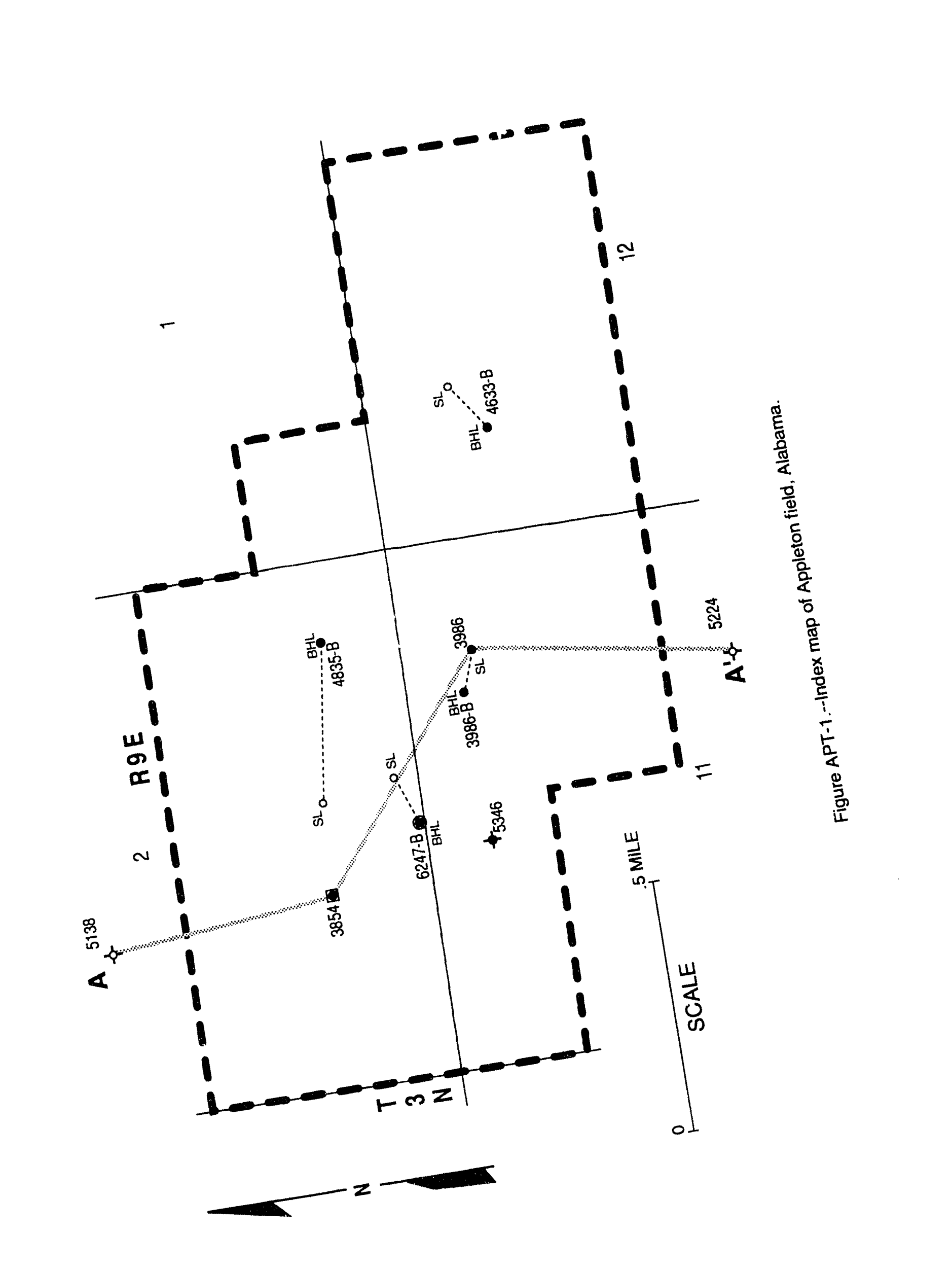




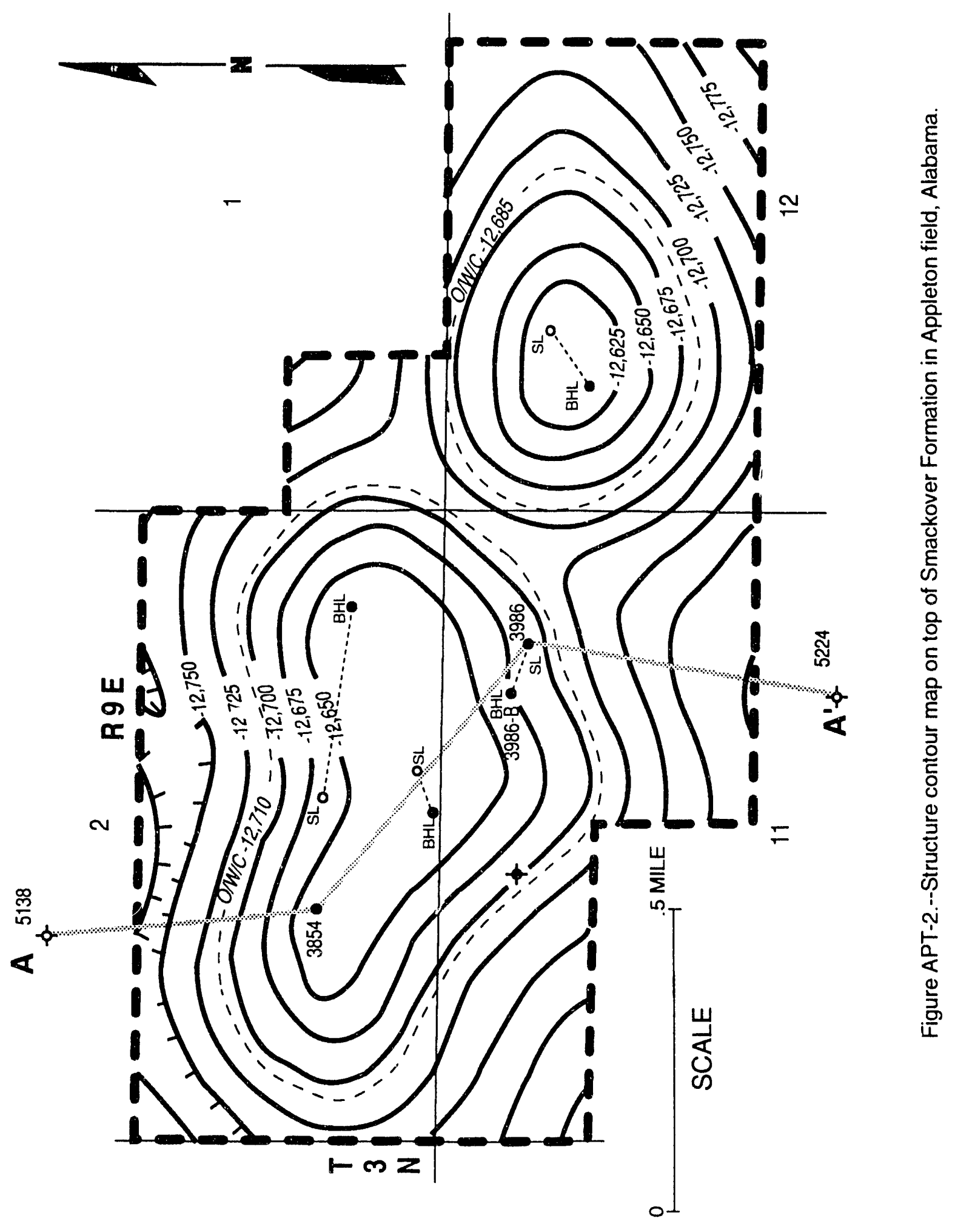




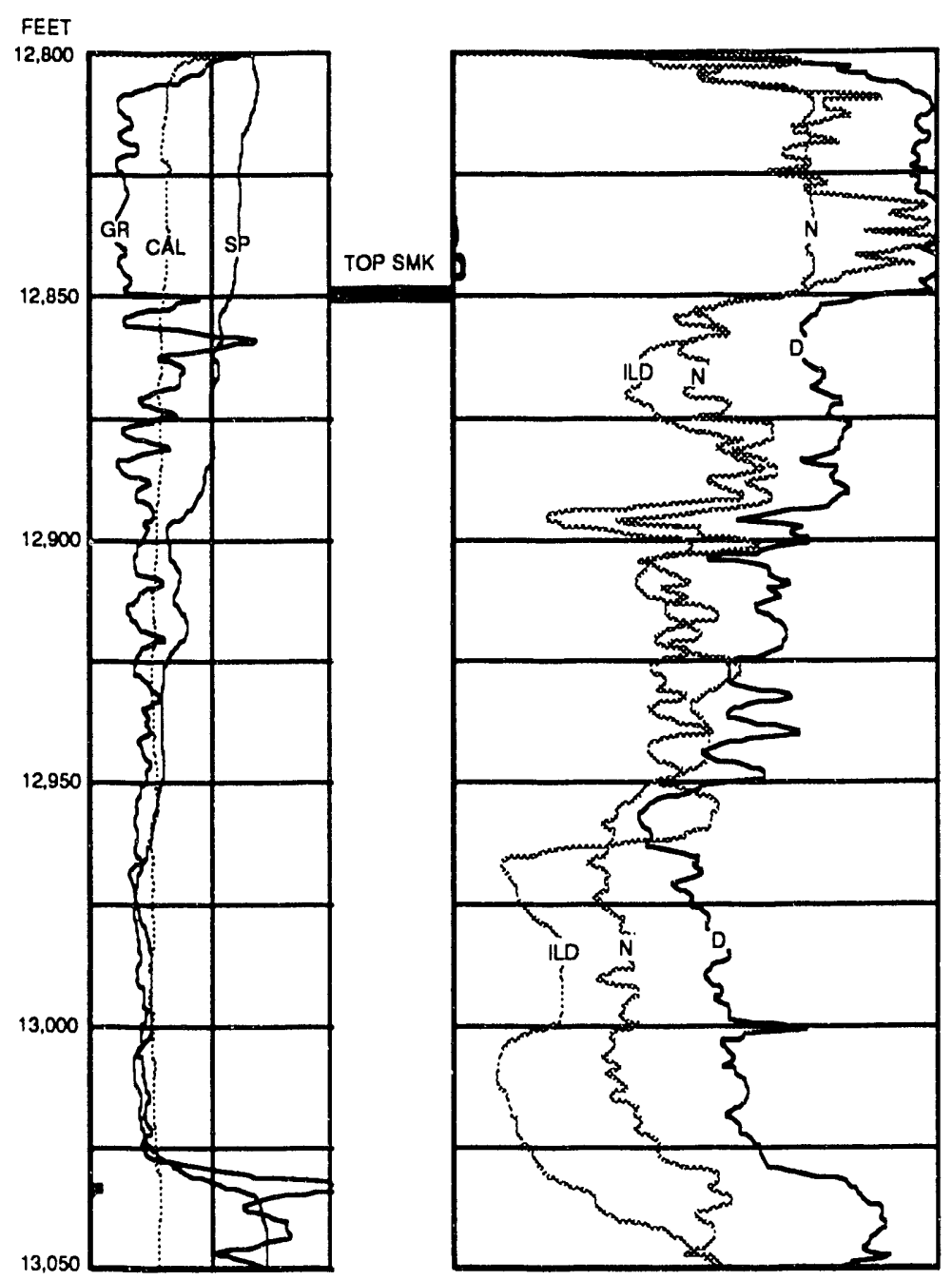

Figure APT-3.--Well log, McMillan 2-14 No. 1 well, Permit No. 3854, Appleton field, Alabama. 


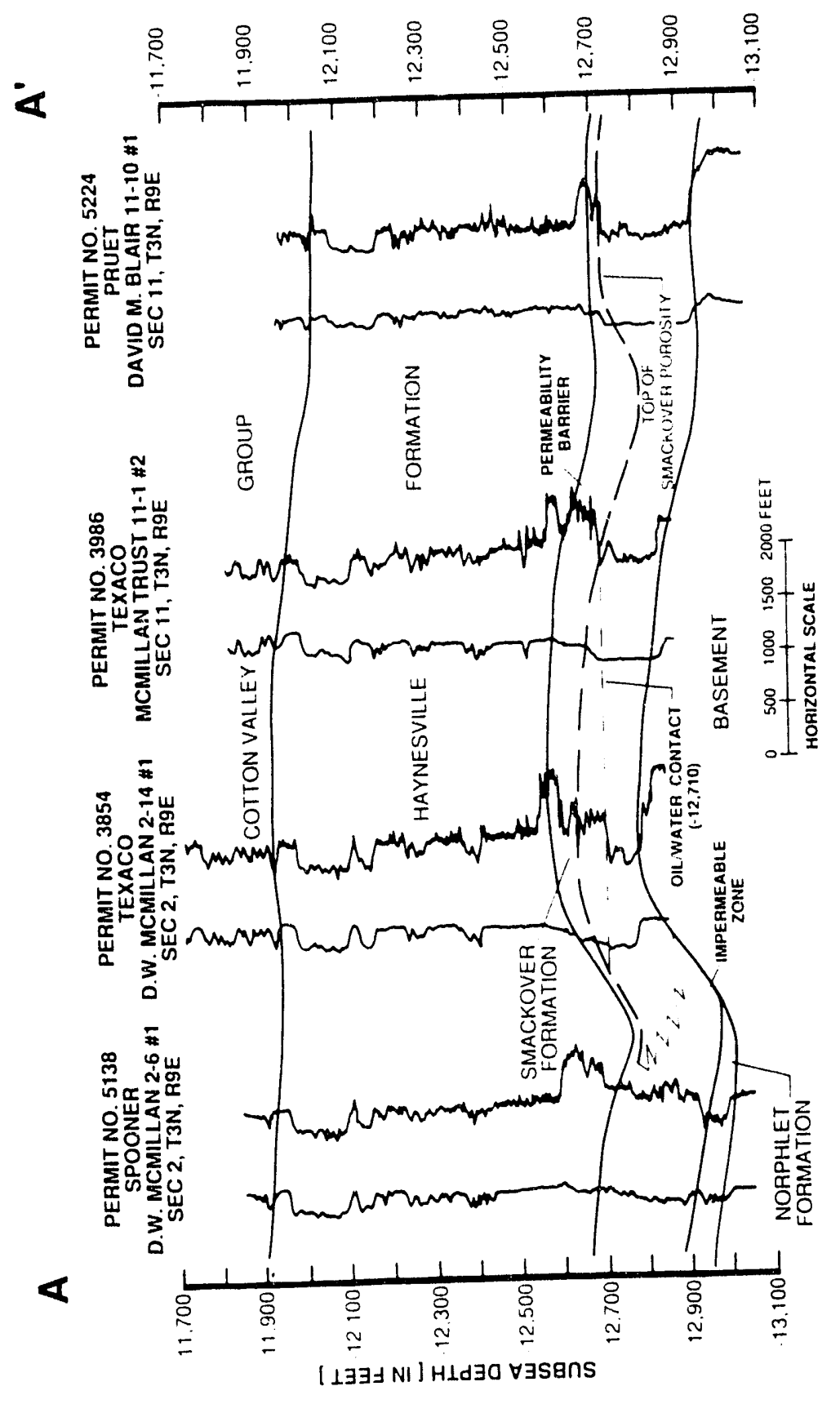

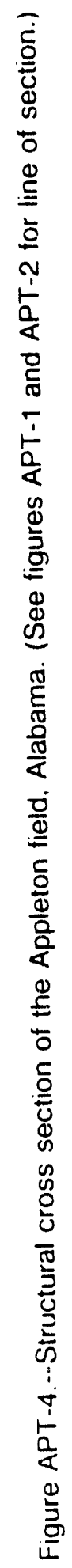




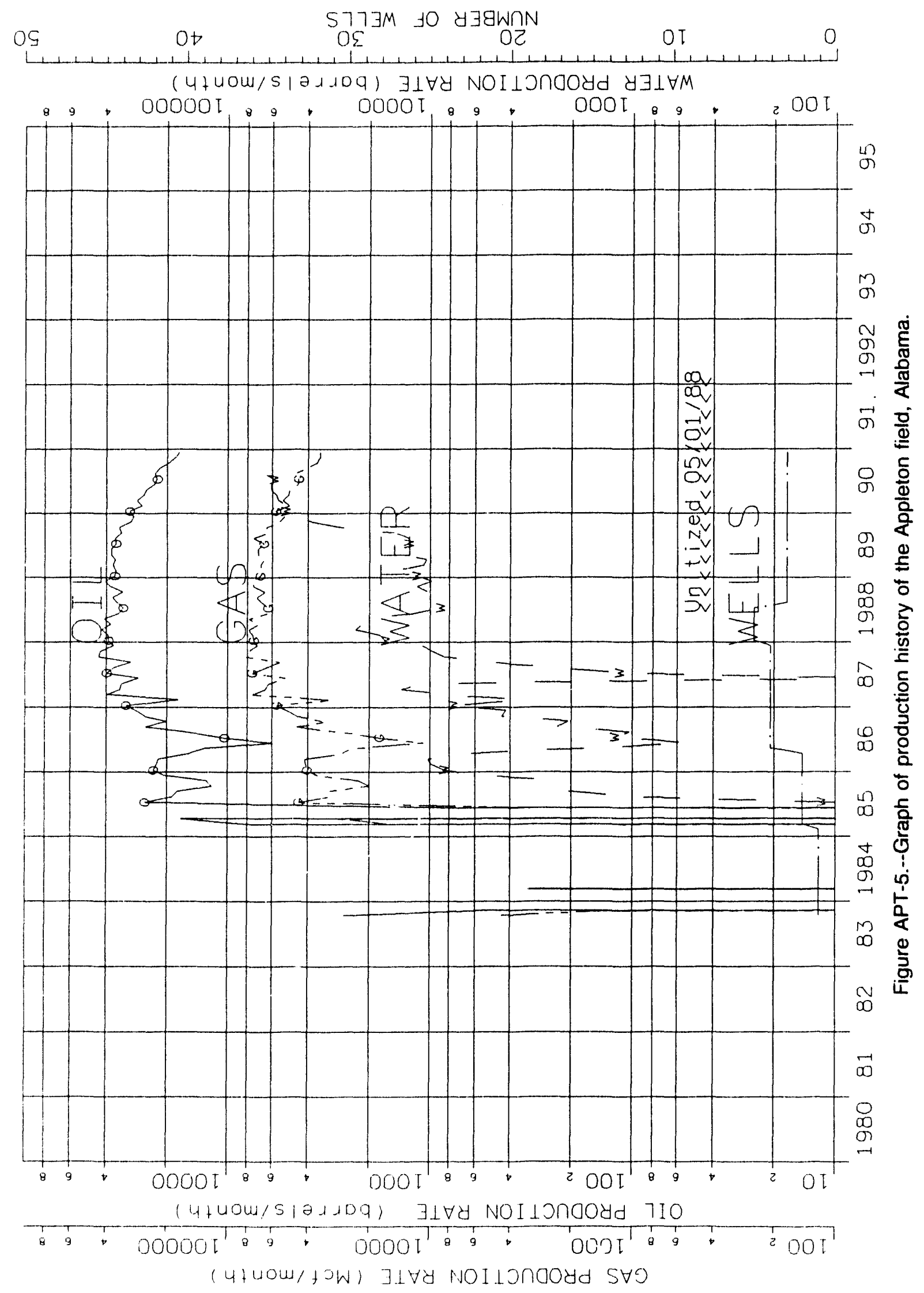




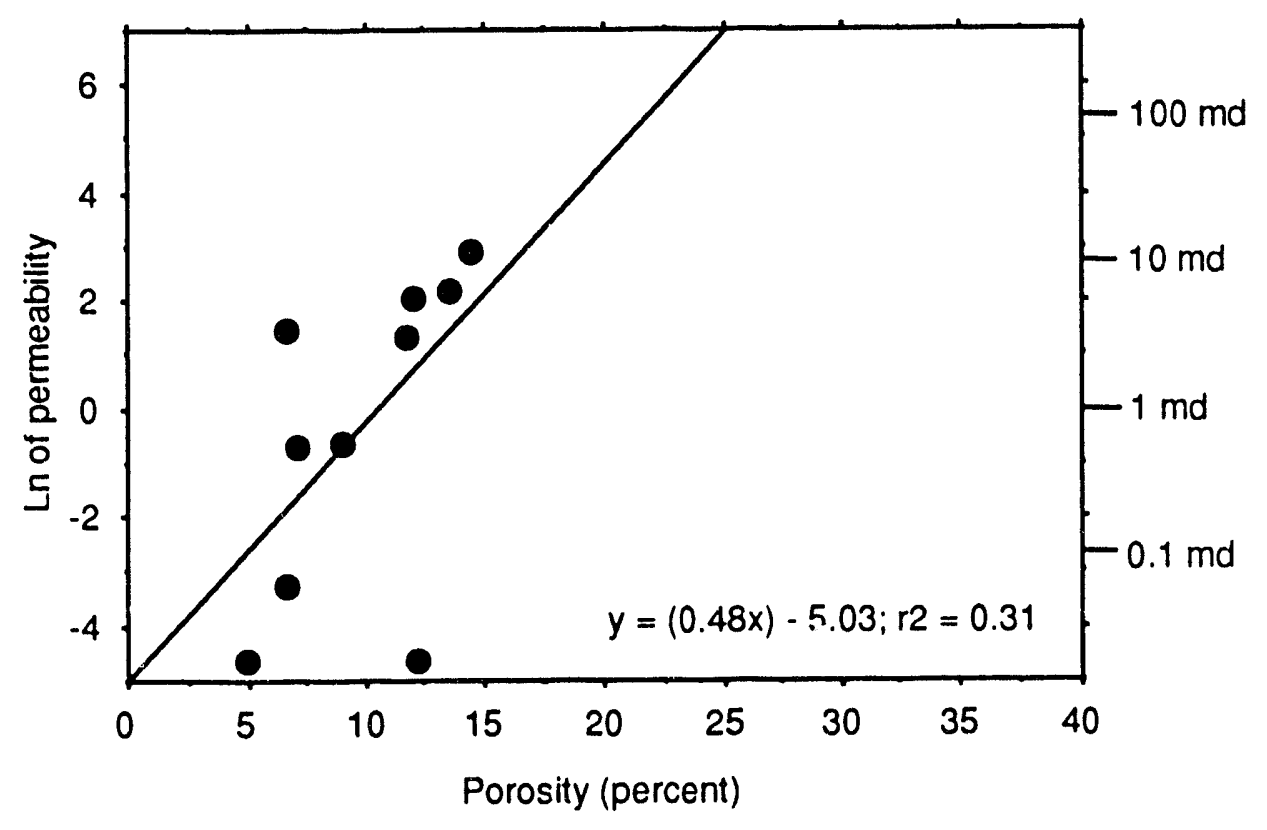

Figure APT -6.--Porosity vs. natural log permeability plot of described core from D. W. McMillan 2-15 No. 5 well. Permit No. 6247, Appleton field, Alabama. Equation applies to regression line. 
Table APT-1.--Reservoir characterization sheet, Smackover pool, Appleton field, Escambia County, Alabama

\section{Discovery well}

Operator: Texaco, U.S.A.

Permit number: 3854

Well Name: D.W. McMillan Trust 2-14 \#1

Location: Sec. 2, TSN-R9E

Completion date: $10 / 19 / 83$

Perforations: $i 2,902-12,938 \mathrm{ft}$

Initial flow rate: 661 bopd, 1,060 Mcfd,

$16 / 64$

\section{Fleld data (as of 12/31/90)}

Number of wells within field limits: 7

Producing wells in pool: 4

Production wells in field: 4

Shut-in/Temp. abandoned wells: 0

Plugged and abandoned wells: 2

Salt water disposal wells: 1

Enhanced recovery wells: 0

Dry holes: 2

Drilling wells: 0

Unit spacing (acres): Unitized

Total field area (acres): $\quad 840$

Cumulative production

Condensate (bbl): 994,987

Gas (Mcf): 1,885,911

Water (bbl): 1,015,865

\section{Reservolr data}

Trap type: Structural

Resenoir structure: Anticline

Proven productive area (acres): 473

Average net pay thickness (feet): 39

Hydrocarbon type: Oil

Oil gravity (API): 52

Initial reservoir pressure (psia): 6,285

Current reservoir pressure (psia): 5,700

Reservoir drive: Solution gas/water

Type of enhanced recovery: none

Mean porosity (core) (\%): 5.94

Porosity standard deviation (\%): 3.75

Maximum porosity (\%): 1.00

Minimum porosity (\%): 14.30

Number of porosity analyses: 30

Geometric mean perm (core) (md): 0.69

Maximum permeability (md): 18.80

Minimum permeability (md): 0.01

Number of permeability analyses: 10

Dykstra-Parsons coefficient: na 


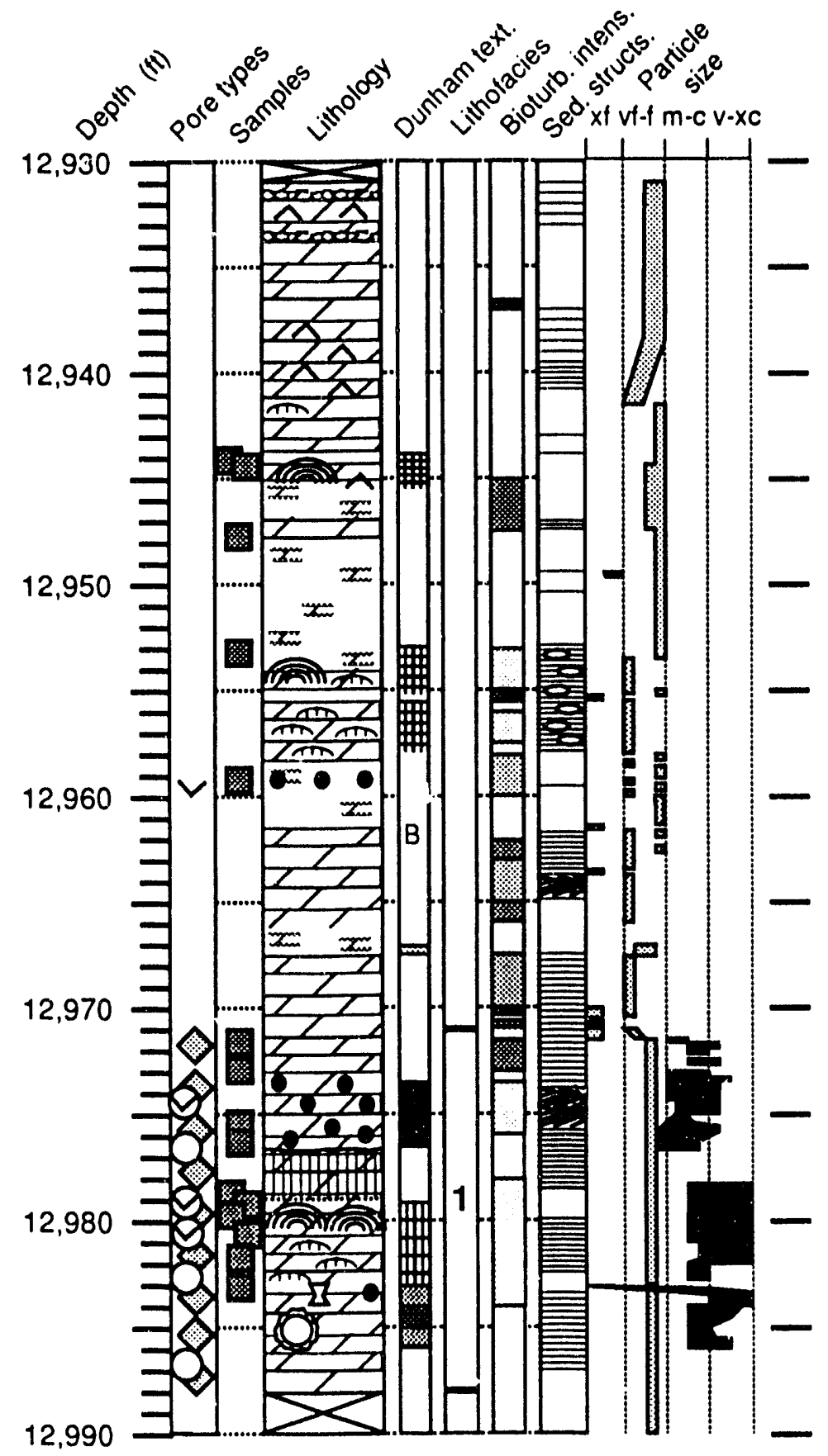

Figure APT-7,.-Detailed core log, D. W. McMillan 2-15 No. 5 well, Permit No. 6247, Appleton field, Alabania. 
Table APT-2.--Lithofacies description of core from D. W. McMillan 2-15 No. 5 well, Permit No. 6247 , Appleton field, Alabama (see figure APT-7)

Lithofacies 1: Microbial doloboundstone, dolomitized karst, peloid dolograinstone, other rock types

Pore types:

Intercrystalline: $46 \%$

Moldic: $37 \%$ [much of this is shelter porosity identifiable only in thin section]

Vuggy: $17 \%$ [much of this is shelter porosity identifiable only in thin section]

Depositional Environment: Backbarrier lagoon, rapid upward shoaling to restricted peritidal setting followed by exposure.

Diagenesis: Mature karstification of microbial boundstone with development of vadose pisolite and of solution pipes. Early karst-associated fractures filled with calcite cement. Nonfabric selective dolomitization (second episode; early very finely crystalline dolomite is restricted to nonporous intervals higher in the core) and associated dissolution modified the primary pore system, which was dominated by shelter porosity in boundstone and by interparticle porosity in pellet grainstone (primary fabric is partially preserved where dolomitization was incomplete). Most outsize pores (e.g., shelter pores) are lined with euhedral dolomite cement crystals which apparently represent a third episode of dolomitization that took place after pore-system formation.

Percent of reservoir: 100

Depth intervai(s) (ft): $12,971-12,988$ 


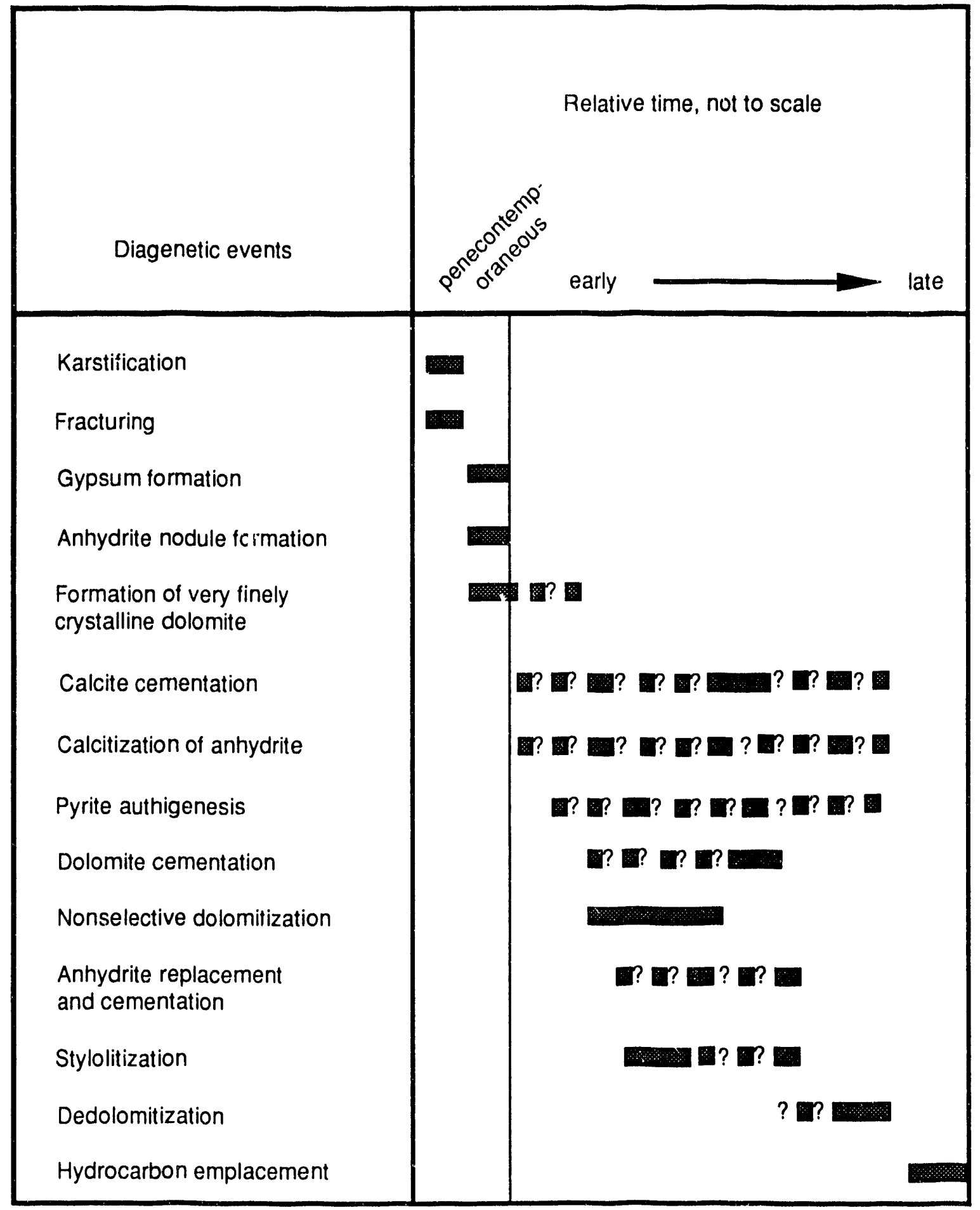

Figure APT-8.--Paragenetic sequence, D. W. McMillan 2-15 No. 5 well, Permit No. 6247, Appleton field, Alabama. 
BARNETT FIELD

SMACKOVER OIL POOL.

\section{CONECUH AND ESCAMBIA COUNTIES, ALABAMA}




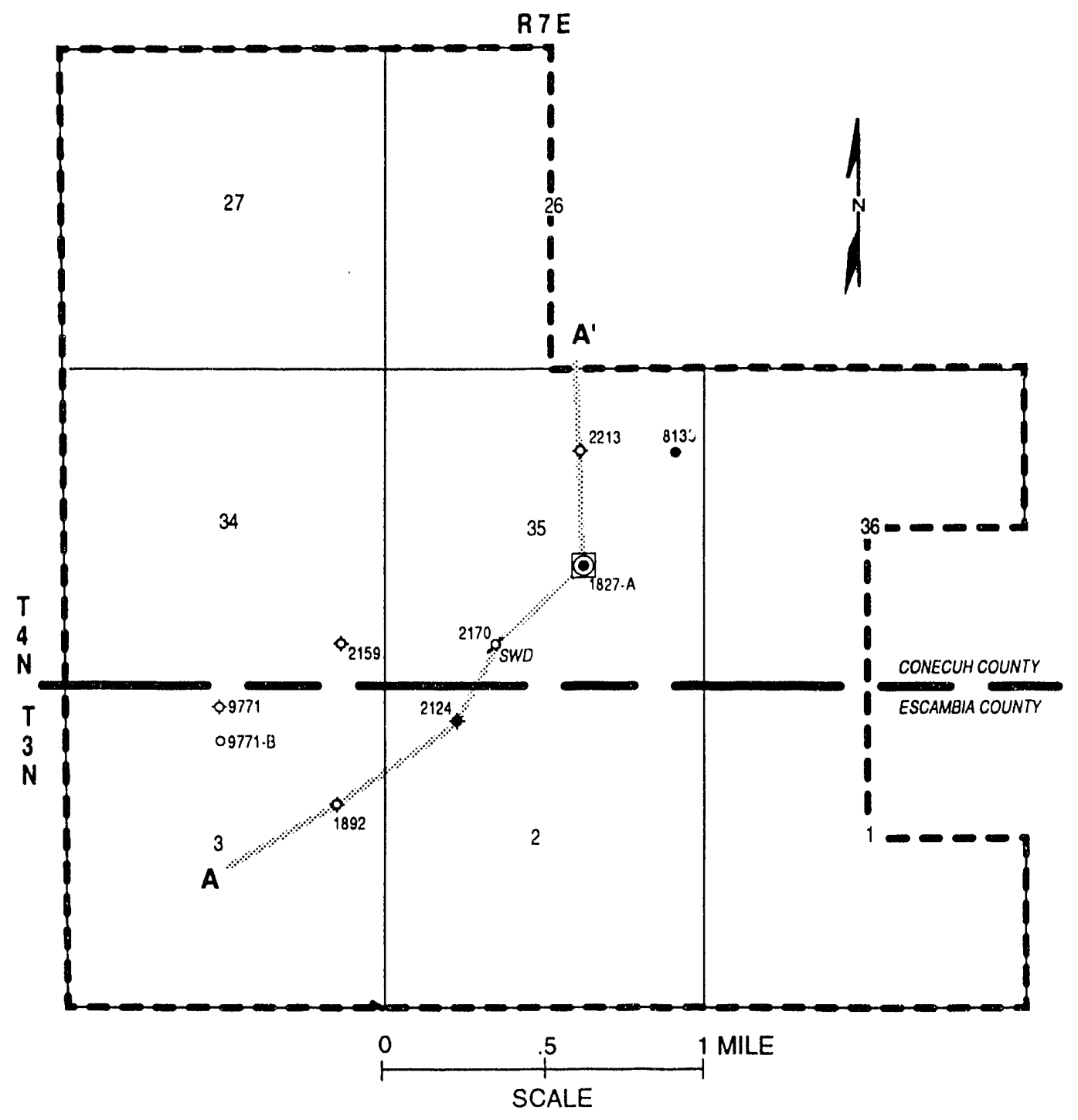

Figure BAR-1,--Index map of Barnett field, Alabama. 


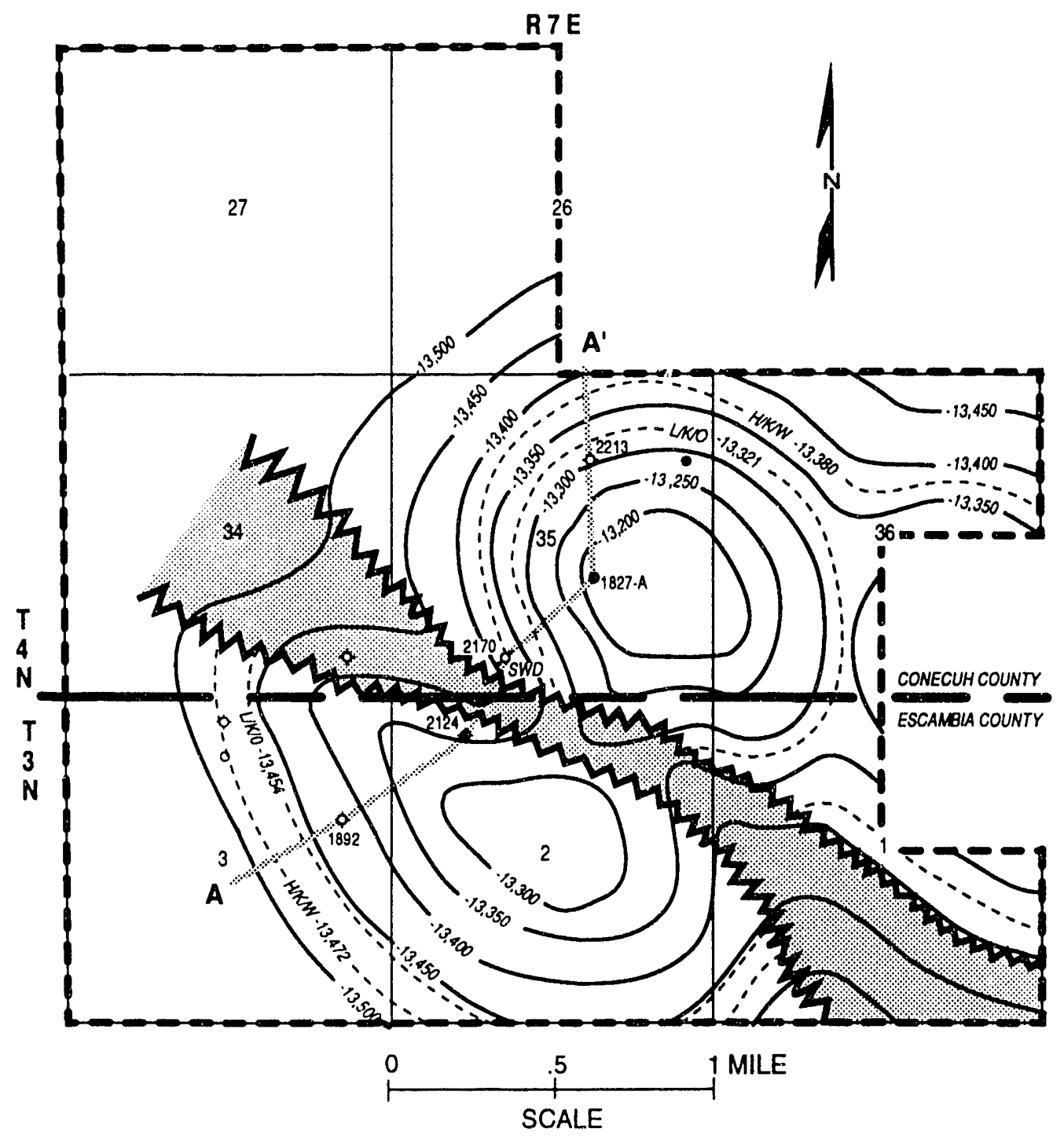

Figure BAR-2.--Structure contour map on top of Smackover Formation in Barnett field, Alabama. 


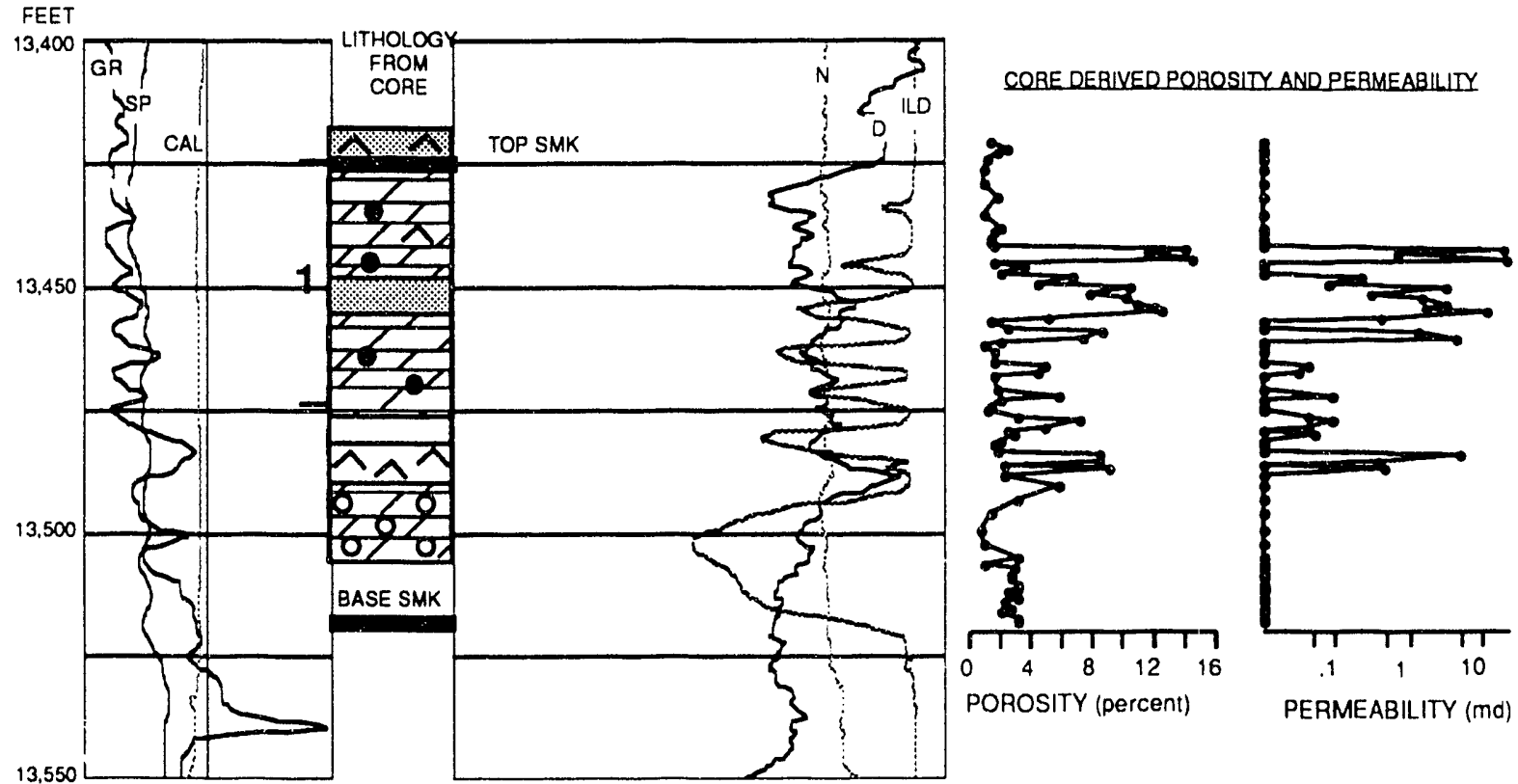

Figure BAR-3.--Well log correlated to lithology, porosity, and permeability, Alger Sullivan "C" No. 1 well, Permit No. 1827, Barnett field, Alabama. 


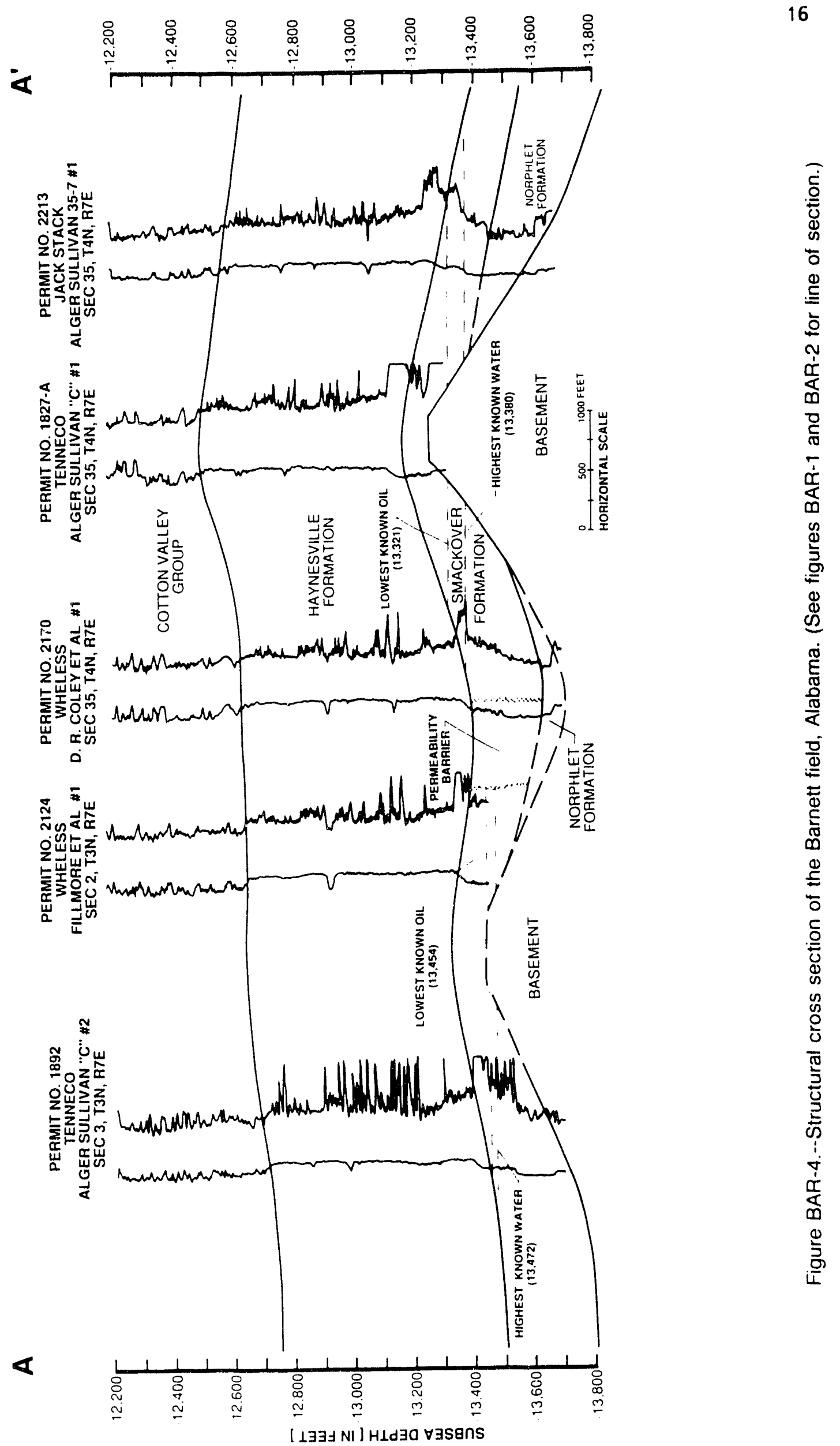




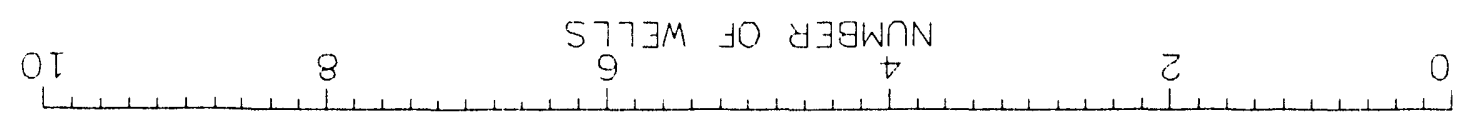

( 4 tuom/s/aגdoq) $\exists \perp \forall y$ NOLLONOOdd $\forall \exists \perp \forall M$

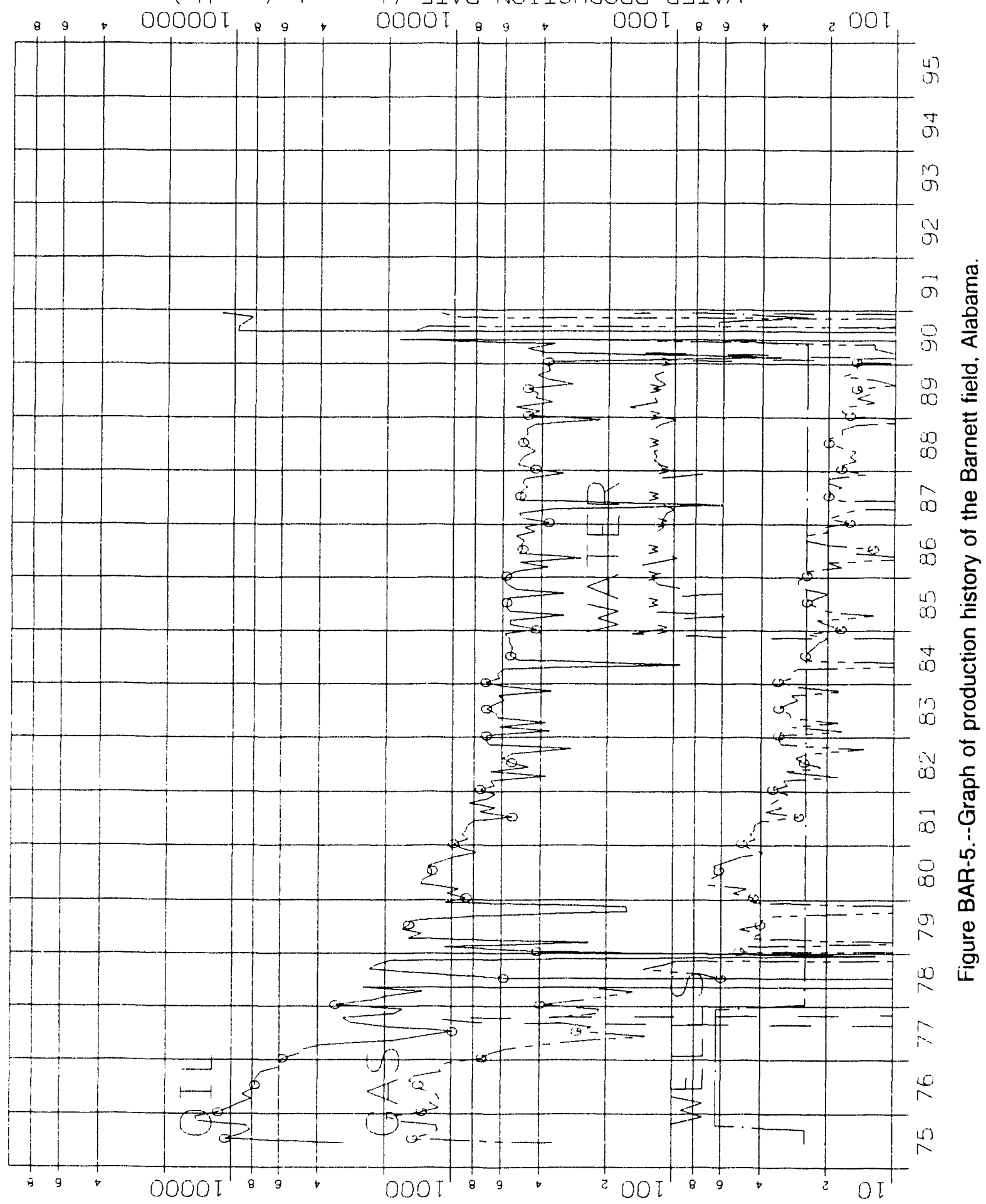

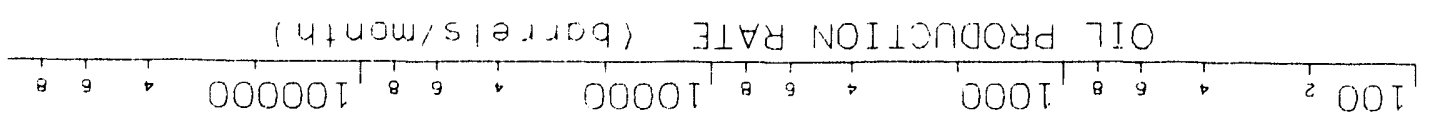

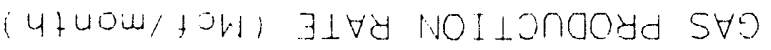




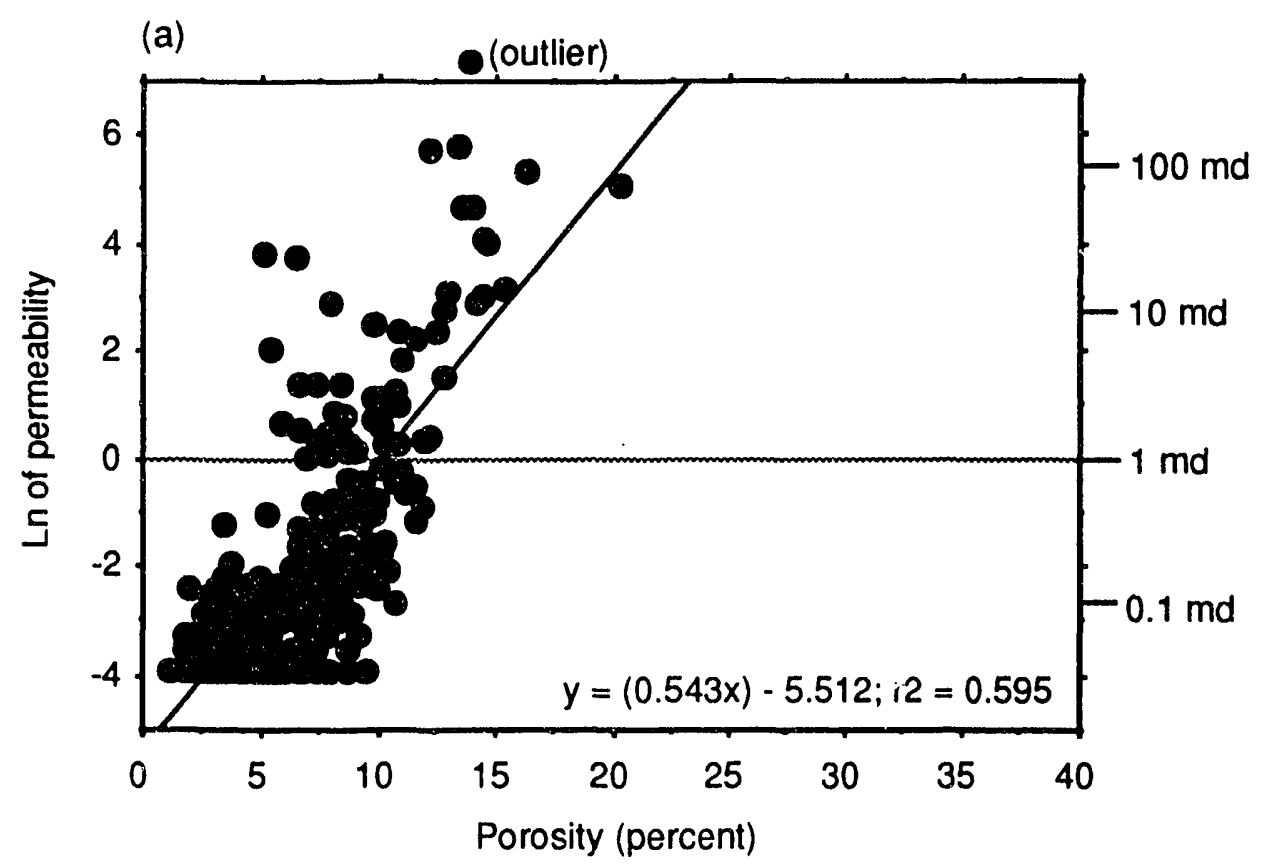

(b)

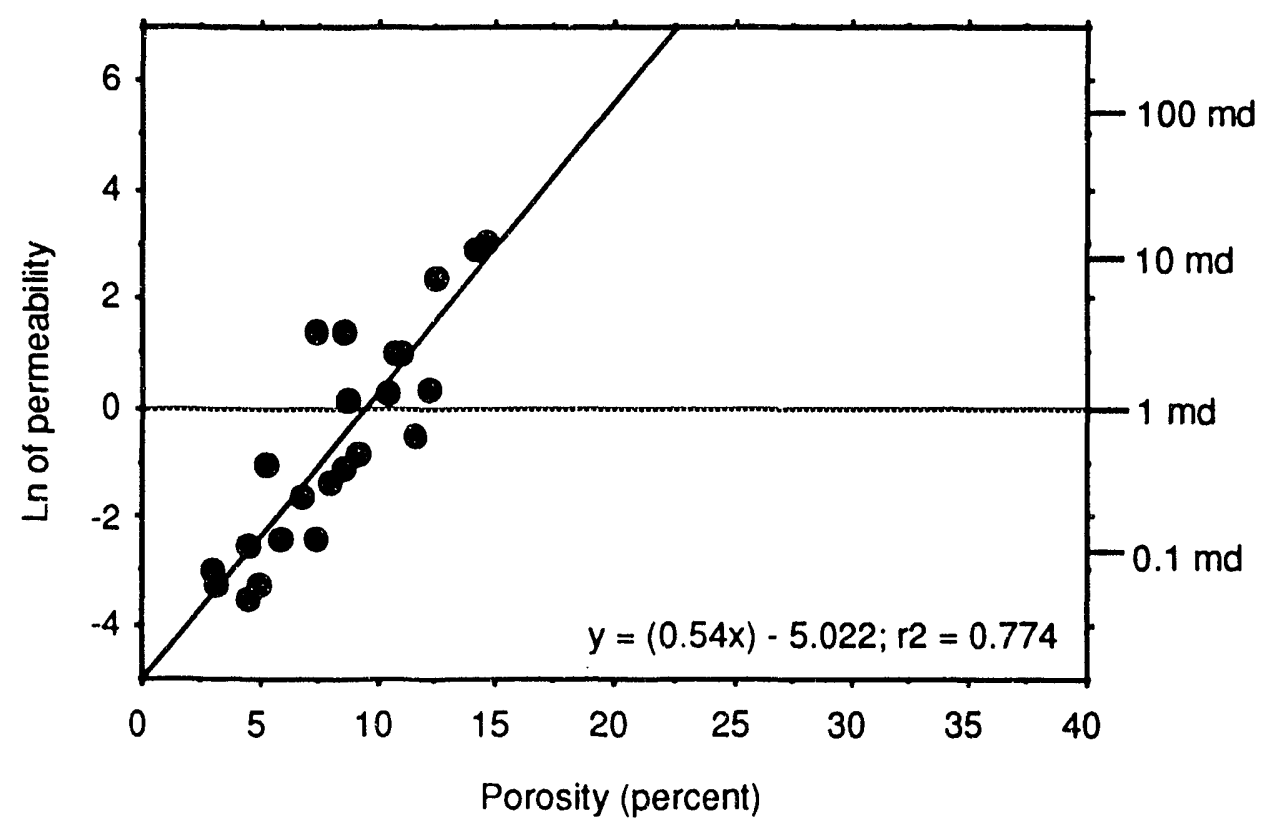

Figure BAR-6.-.Porosity vs. natural log permeability plots, Barnett field, Alabama. (a) Plot of siz cores combined, and (b) plot of decribed core for Alger Sullivan " $C$ " No. 1 well, Permit No. 1827-A. 
Table BAR-1.--Reservoir characterization sheet, Smackover pool, Barnett field, Conecuh and Escambia Counties, Alabama

\section{Discovery well}

Operator: Wheless Ind. - Jack E. Stack

Permit number: $1827-\mathrm{A}$

Well Name: Alger Sullivan \#1

Location: Sec. 35, T4N-R7E

Completion date: 6/08/75

Perforations: $13,430-13,476 \mathrm{ft}$

Initial flow rate: 523 bopd, 740 Mcfd,

$$
12 / 64 \text { ck, } 1,985 \text { psi }
$$

Field data (as of 12/31/90)

Number of wells within field limits: 9

Producing wells in pool: 2

Production wells in field: 2

Shut-in/Temp. abandoned wells: 0

Plugged and abandoned wells: 5

Salt water disposal wells: 1

Enhanced recovery wells: 0

Dry holes: 0

Drilling wells: 1

Unit spacing (acres): unitized

Total field area (acres): 5,760

Cumulative production

Oil (bbl): 324,333

Gas (Mcf): 370,660

Water (bbl): 97,363

\section{Reservoir data}

Trap type: Structural / stratigraphic

Reservoir structure: Anticline

Proven productive area (acres): 1,237

Average net pay thickness (feet): 12

Hydrocarbon type: Oil

Oil gravity (API): 49

Initial reservoir pressure (psia): 6,618

Current reservoir pressure (psia): 2,800

Reservoir drive: Solution gas

Type of enhanced recovery: none

Mean porosity (core) (\%): 6.00

Porosity standard deviation (\%): 3.30

Maximum porosity (\%): 20.20

Minimum porosity (\%): 1.00

Number of porosity analyses: 273

Geometric mean perm (core) (md): 0.14

Maximum permeability (md): 1670.00

Minimum permeability (md): 0.01

Number of permeability analyses: 273

Dykstra-Parsons coefficient: na 


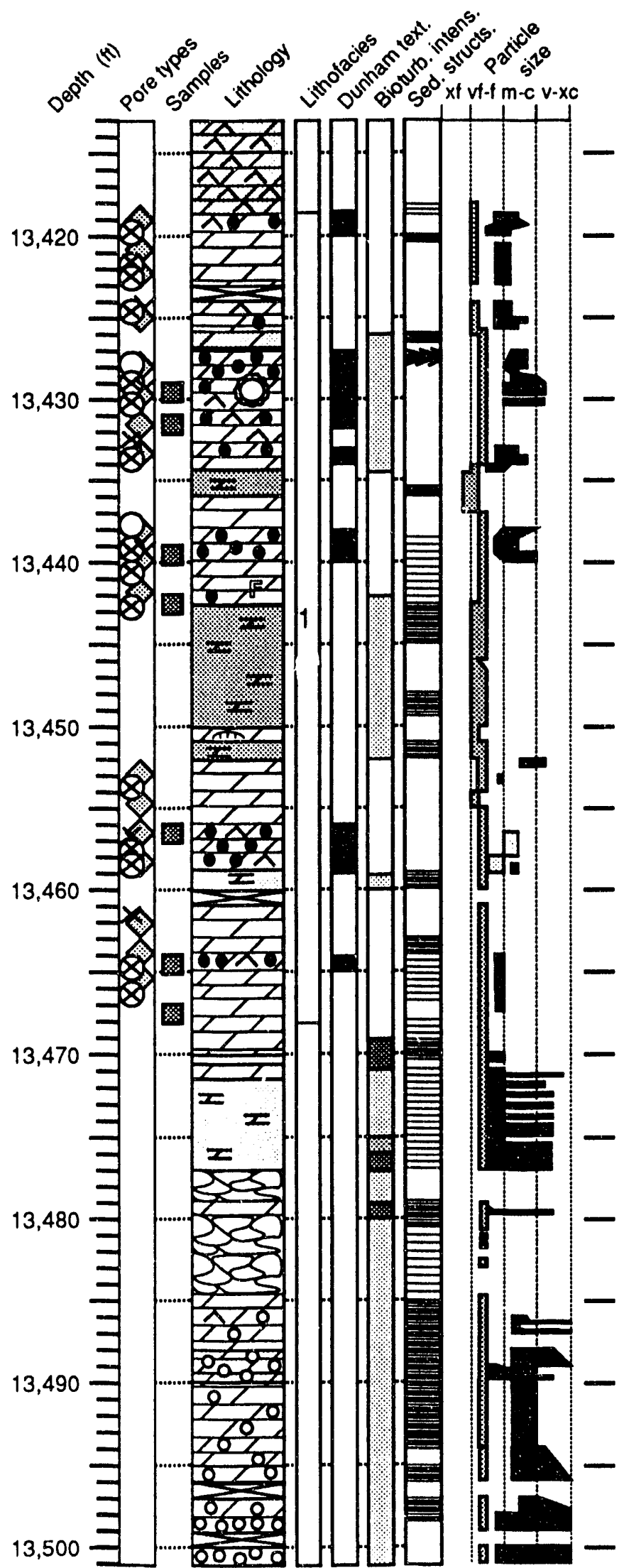

Figure BAR-7.--Detailed core log, Alger Sullivan "C" No. 1 well, Permit No. 1827-A, Barnett field, Alabama. 
Table BAR-2.--Lithofacies description of core from Alger Sullivan "C" No. 1 well, Permit No. 1827A, Barnett field, Alabama (see figure BAR-7)

Lithofacies 1: Peloidal dolostone with intercalated dolomitic siltstone and dolomitic sandstone [only the carbonates are permeable]

Pore types:

Intercrystalline: $56 \%$

Secondary intraparticle: $22 \%$

Moldic: $19 \%$

Vuggy: $3 \%$

Mean porosity (\%): 8.1

Maximum porosity (\%): 14.5

Minimum porosity (\%): 2.9

Porosity standard deviation (\%): 3.4

Number of analyses: 24

Geometric mean permeability (md): 0.53

Maximum permeability (md): 21.00

Minimum permeability (md): 0.03

Number of analyses: 24

Depositional environment: Tidal flat and shallow lagoon near subaerially exposed source of quartzose sediment.

Diagenesis: Penecontemporaneous growth of displacive anhydrite nodules, pervasive dolomitization, leaching of remnarit calcium carbonate, fracturing before precipitation of anhydrite cement, formation of authigenic anhydrite and pore-filling anhydrite cement, pressure solution, minor pyrite authigenesis.

Percent of reservoir: 100

Depth interval(s) (ft): $13,419-13,468$ 


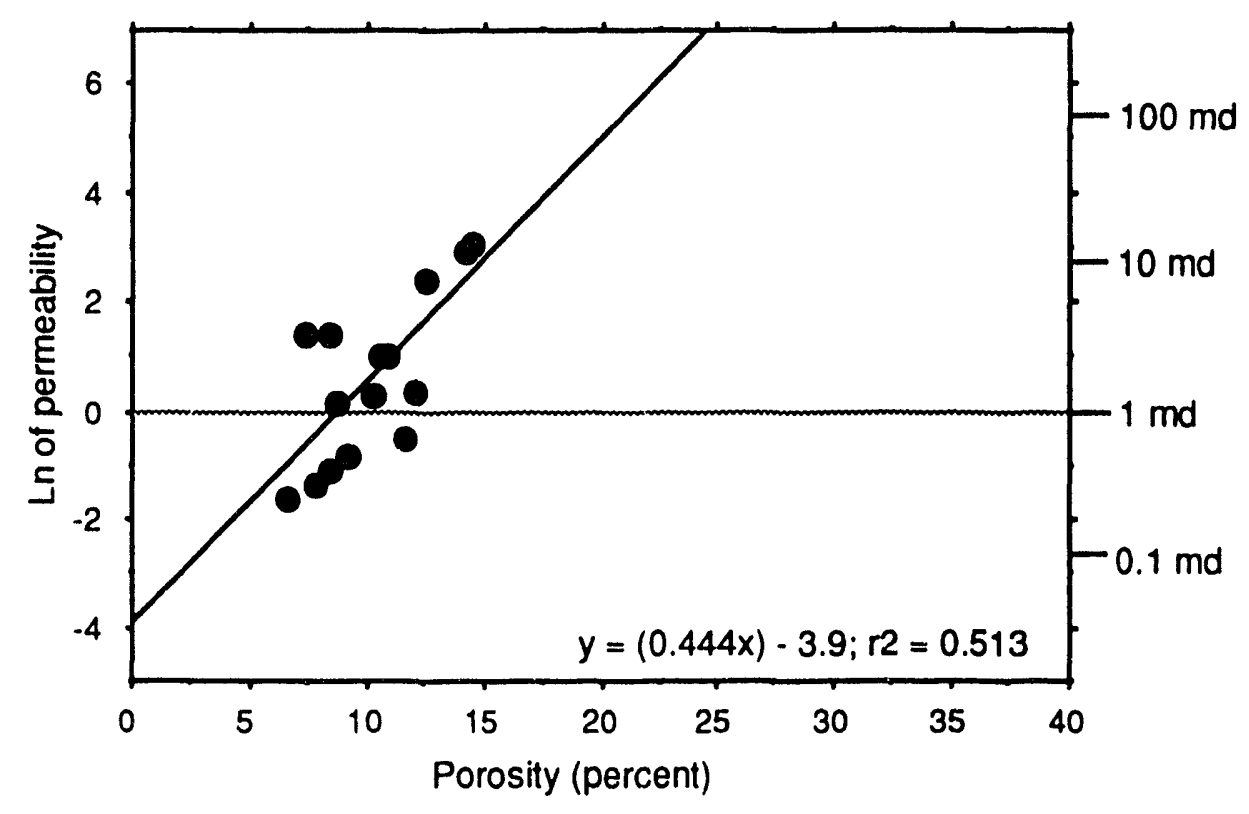

Figure BAR-8.--Porosity vs. natural log permeability plot, Alger Sullivan "C" No. 1 well, Permit No. 1827-A. Barnett field, Alabama. Equation applies to regression line. (See table BAR-2 for description of lithofacies.) Data set excludes all samples with porosity values and permeability values below reservoir cutoffs at $6 \%$ and $0.1 \mathrm{md}$, respectively. 


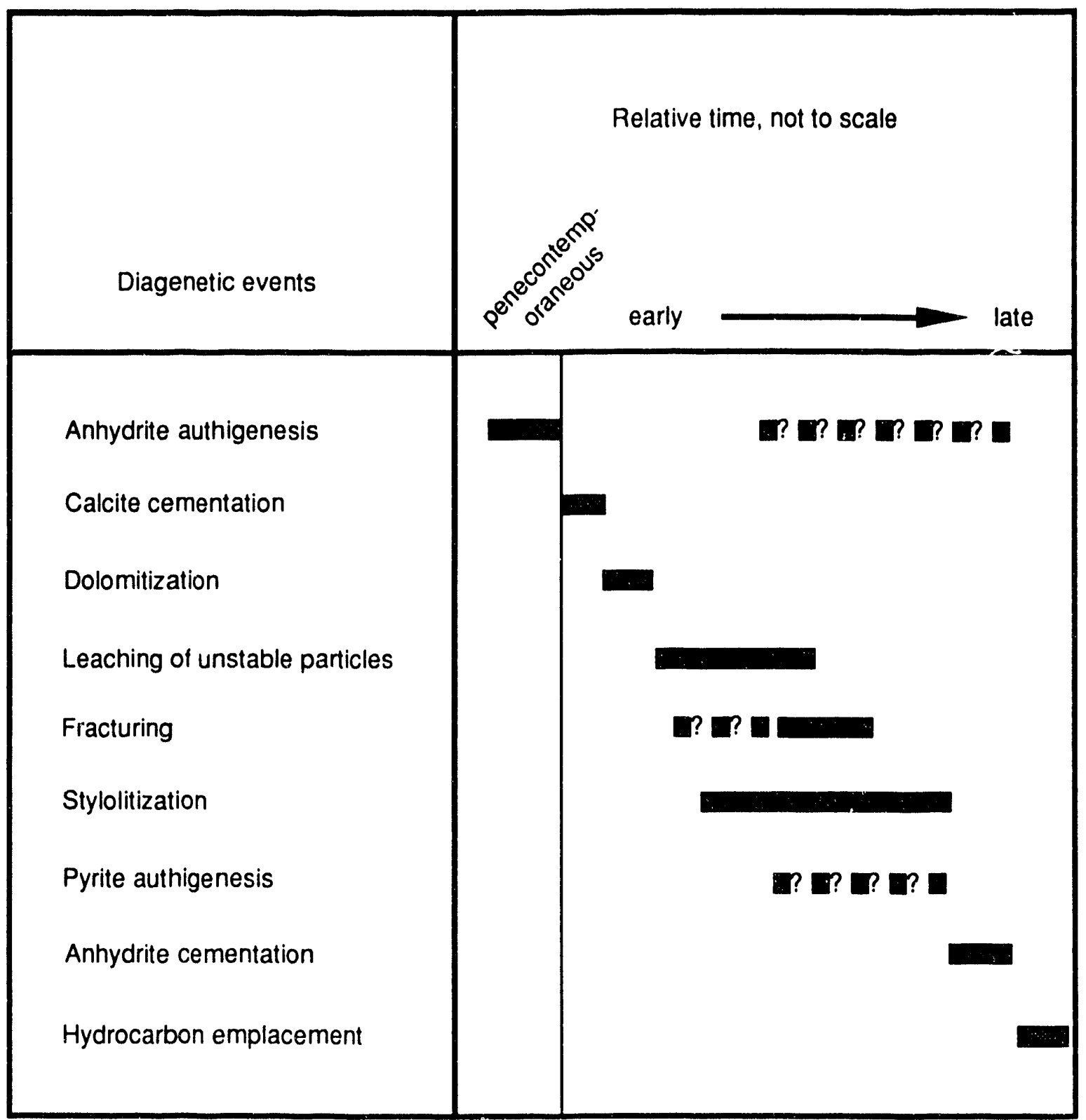

Figure BAR-9.--Paragenetic sequence, Alger Sullivan "C" No. 1 well, Permit No. 1827-A, Barnett field, Alabama. 


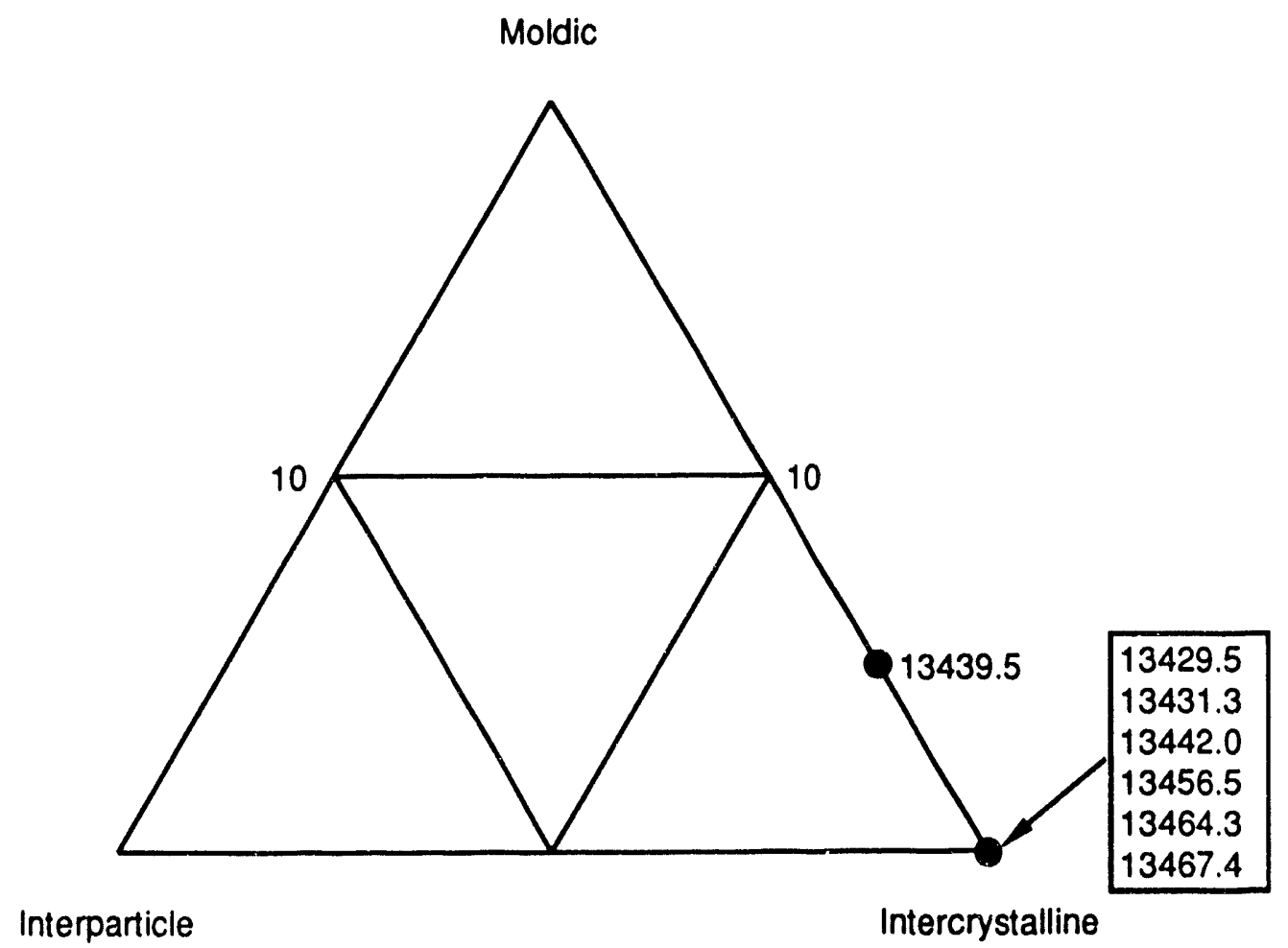

Figure BAR-10.--Ternary diagram of pore types, Alger Sullivan "C" No. 1 well, Permit No. 1827-A, Barnett field, Alabama. Percentages of moldic pores indicated. Sample depths are indicated to nearest 0.1 foot. 
BARLOW BEND FIELD

SMACKOVER OIL POOL

CLARKE AND MONROE COUNTIES, ALABAMA 


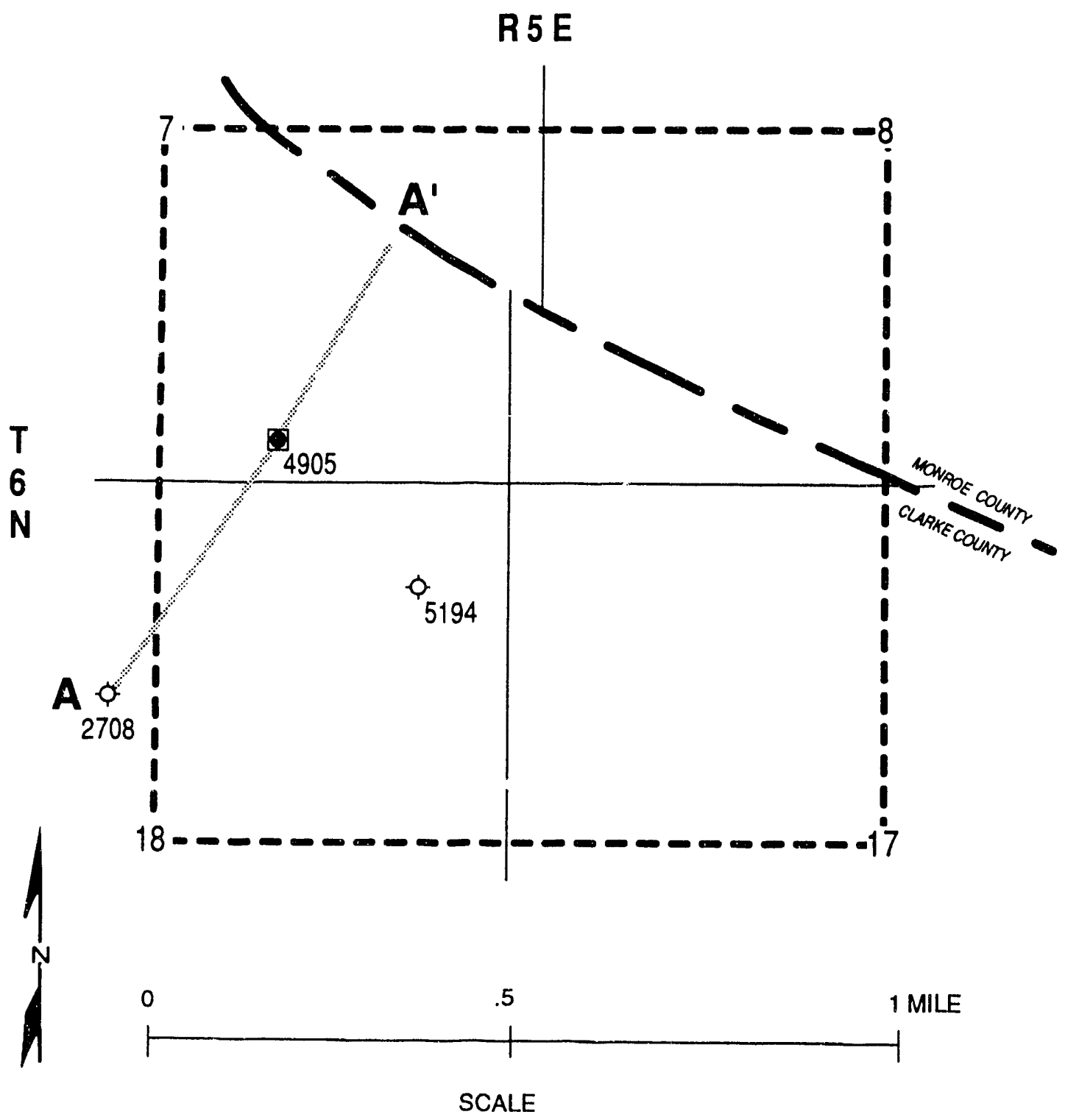

Figure BB-1.--Index map of Barlow Bend field, Alabama. 


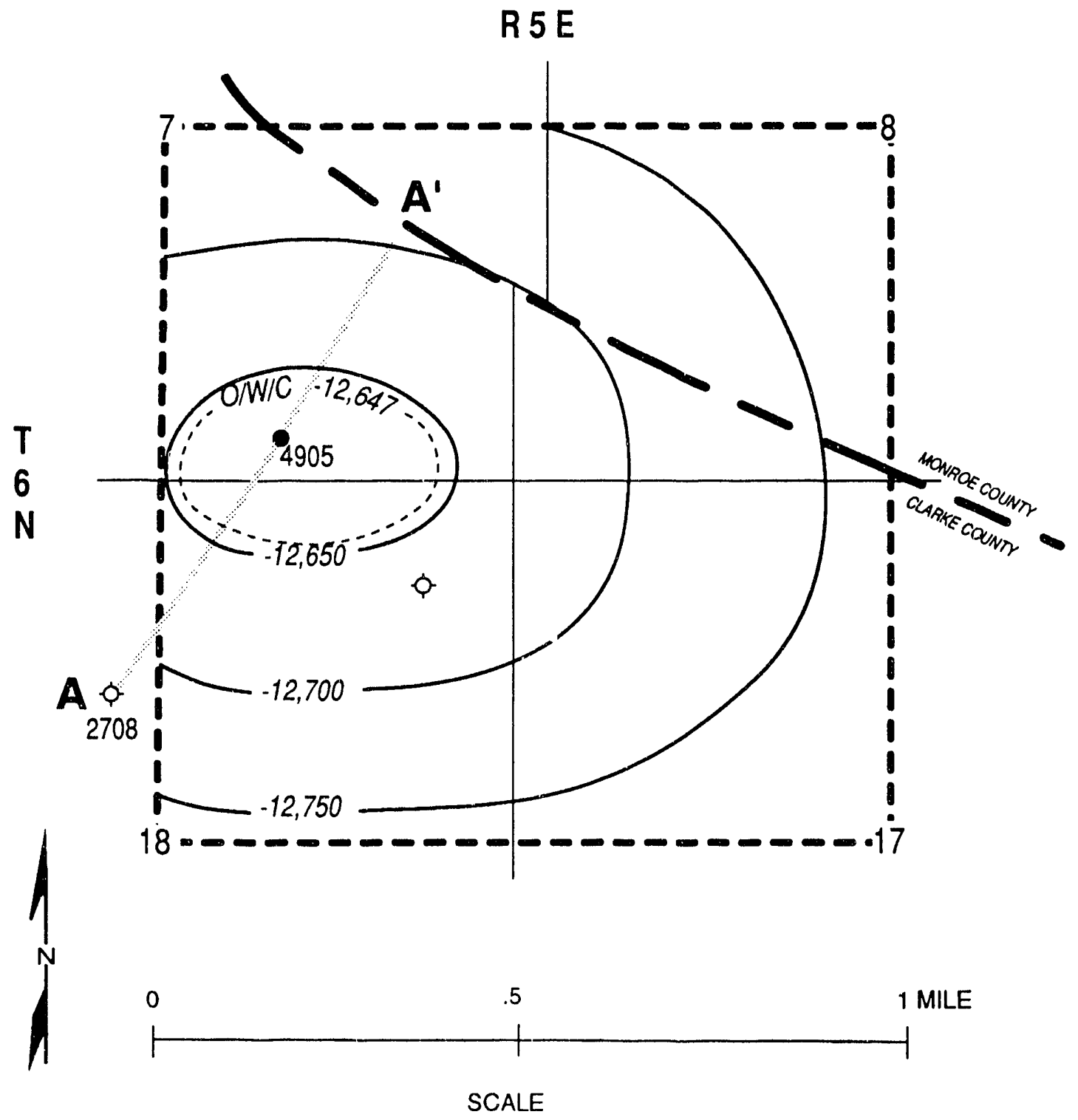

Figure BB-2.--Structure contour map on top of Smackover Formation in Barlow Bend field, Alabama. 


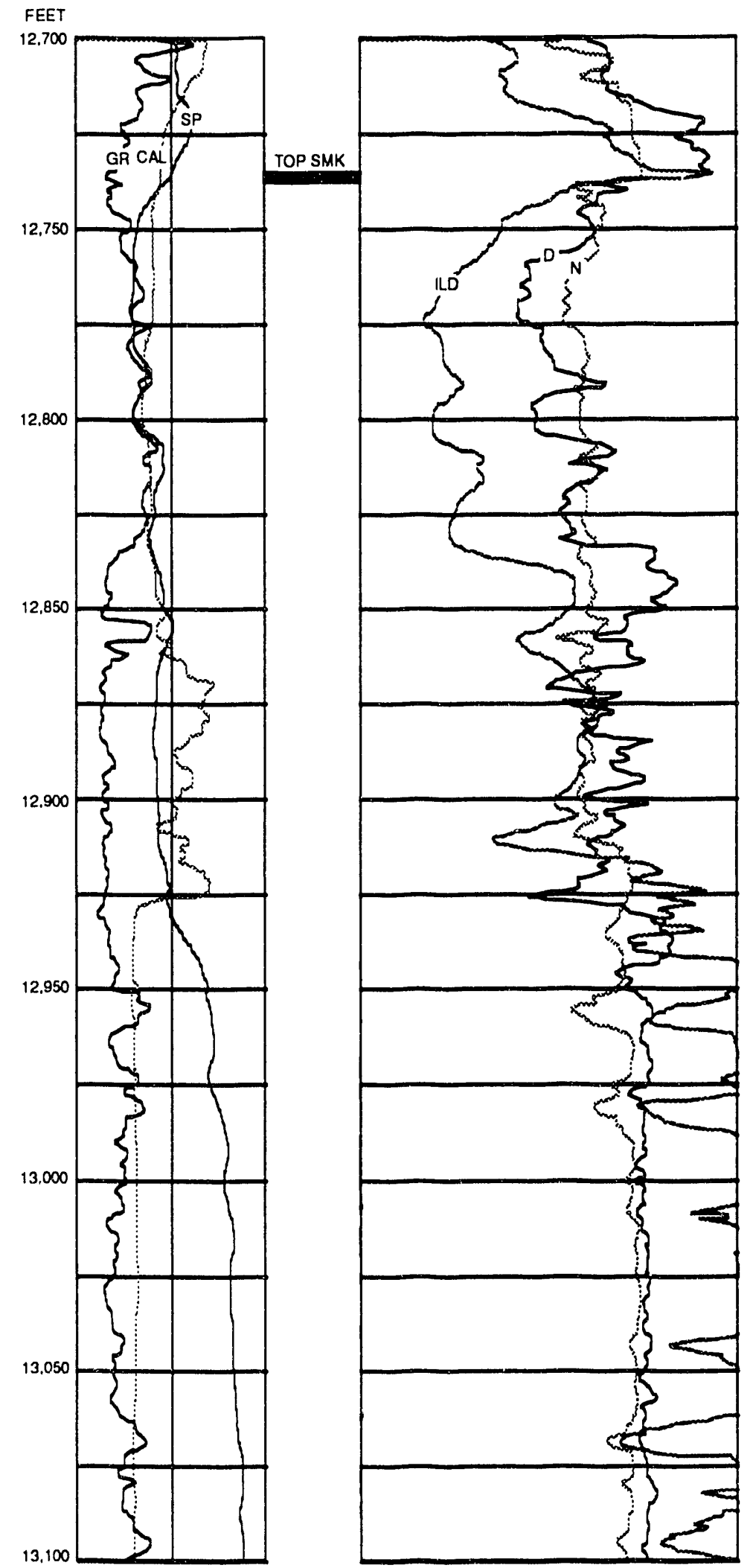

Figure BB-3.--Well log, Henry Gibby Unit 7-15 No. 1 well, Permit No. 4905, Barlow Bend field, Alabama. 


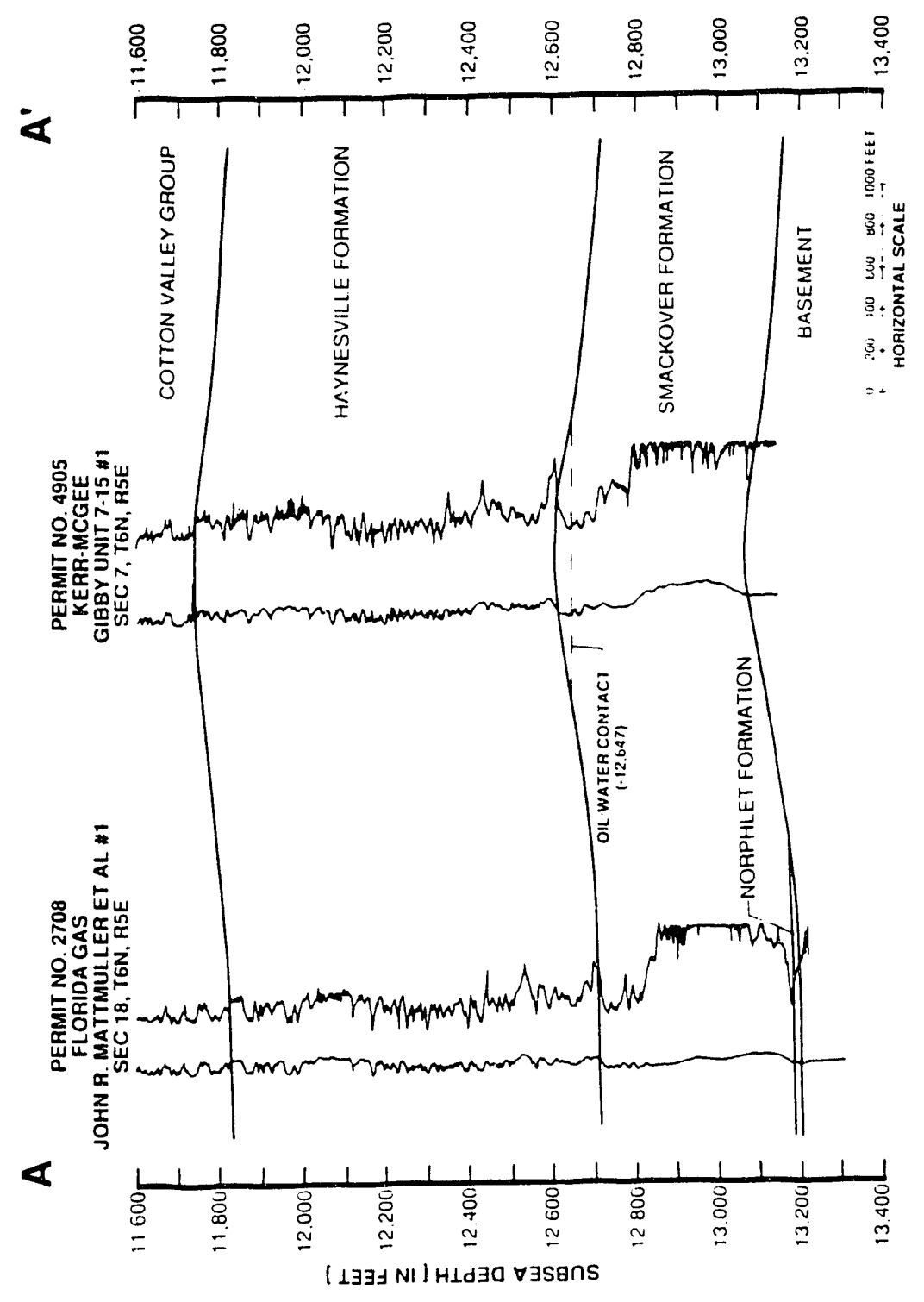

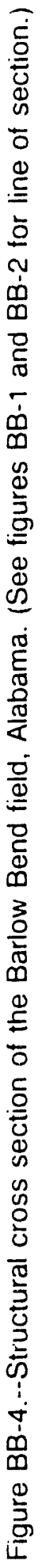




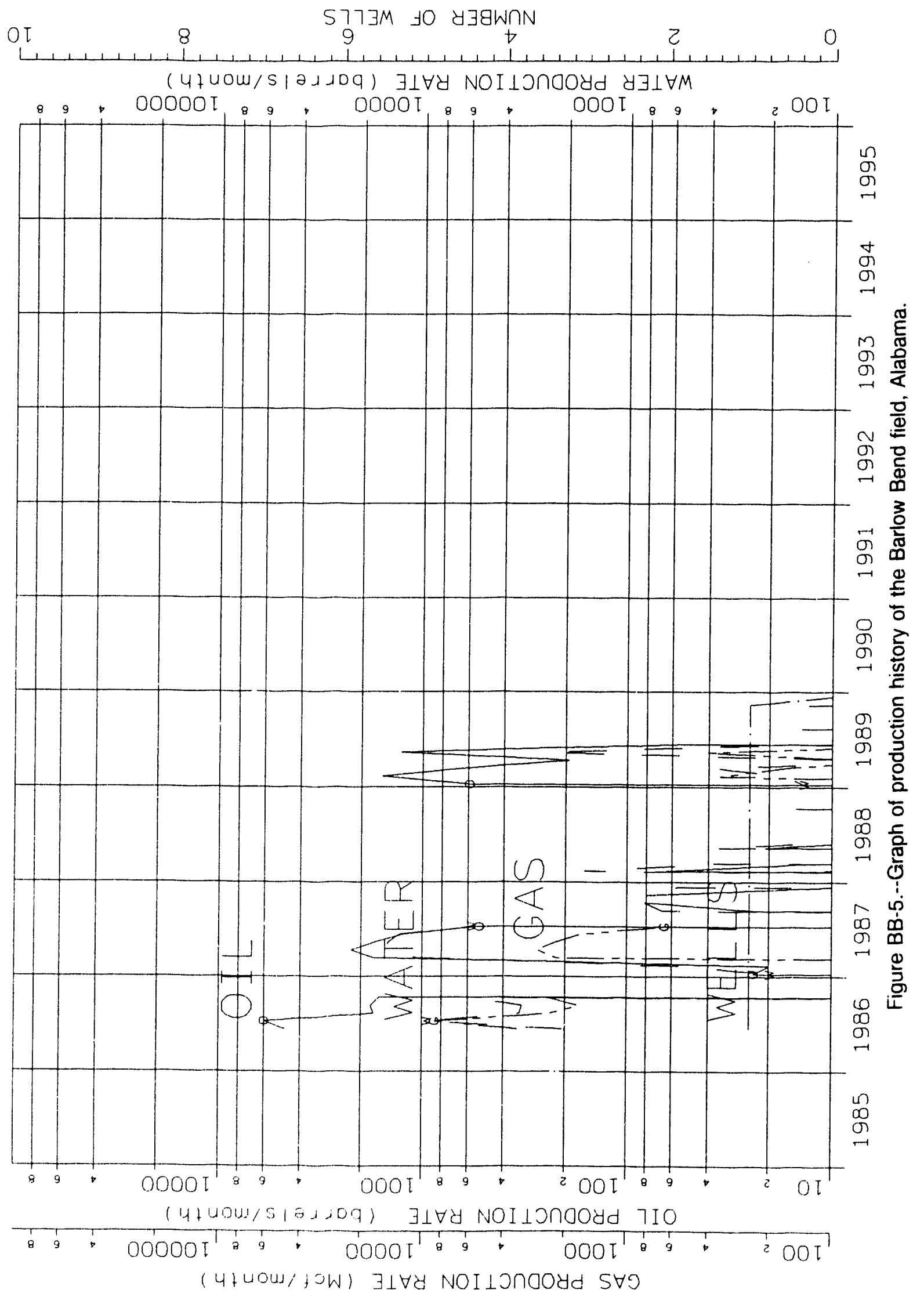




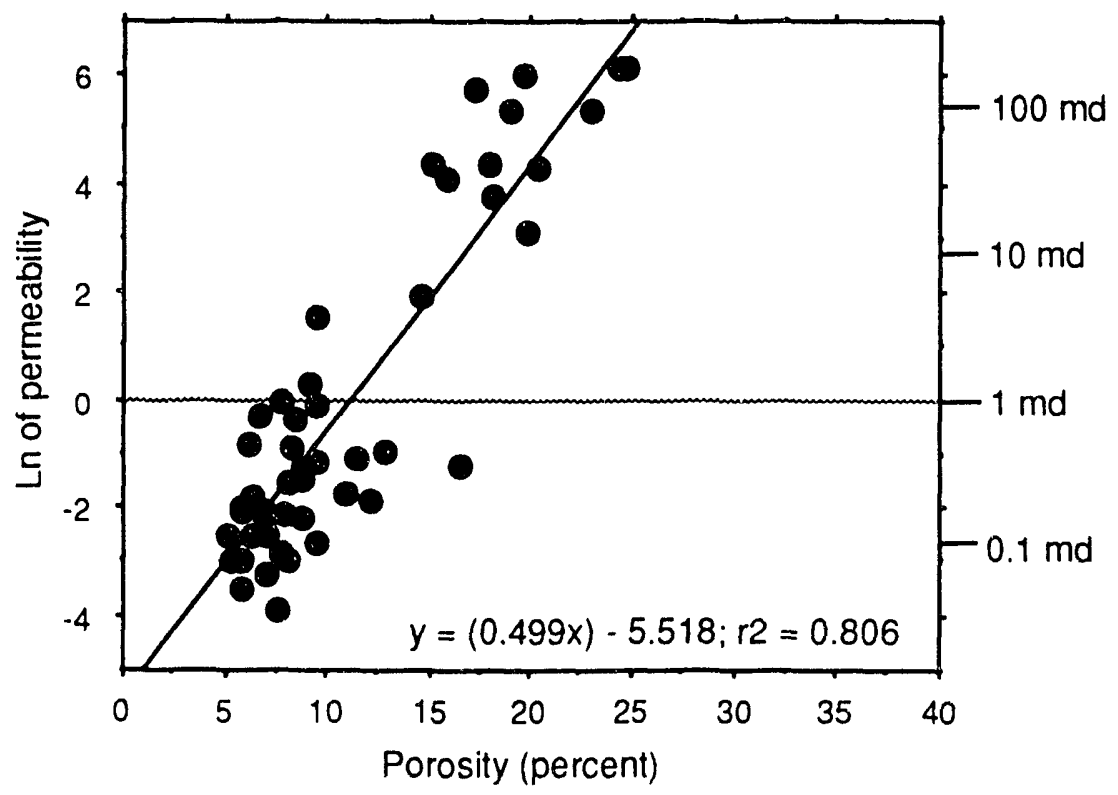

Figure BB-6.--Porosity vs. natural log permeability plot of John R. Mattmuller et al. No. 1 well, Permit No. 2708, Barlow Bend field, Alabama. Equation applies to regression line. 
Table BB-1.--Resenoir characterization sheet, Smackover pool, Barlow Bend field, Clarke and Monroe Counties, Alabama

\section{Discovery well}

Operator: Kerr-McGee Corp.

Permit number: 4905

Well Name: Henry Gibby Unit 7-15 \#1

Location: Sec. 7, T6N-R5E

Completion date: 06/09/86

Perforations: $12,740-12,758 \mathrm{ft}$

Initial flow rate: 838 bopd, 652 Mcfd,

$$
\text { 21/64 ck, } 770 \text { psi }
$$

\section{Field data (as of 12/31/90)}

Number of wells within field limits: 2

Producing wells in pool: 1

Production wells in field: 1

Shut-in/Temp. abandoned wells: 0

Plugged and abandoned wells: 1

Salt water disposal wells: 0

Enhanced recovery wells: 0

Dry holes: 0

Drilling wells: 0

Unit spacing (acres): 160

Total field area (acres): 640

Cumulative production

Oil (bbl): 28,089

\section{Reservoir data}

Trap type: Structural

Reservoir structure: Anticline

Proven productive area (acres): 71

Average net pay thickness (feet): 44

Hydrocarbon type: Oil

Oil gravity (API): 35

Initial reservoir pressure (psia): 6,097

Current reservoir pressure (psia): na

Reservoir drive: Solution gas / water

Type of enhanced recovery: none

Mean porosity (core) (\%): 9.80

Porosity standard deviation (\%): 5.23

Maximum porosity (\%): 24.60

Minimum porosity (\%): 3.90

Number of porosity analyses: 63

Geometric mean perm (core) (md): 0.99

Maximum permeability (md): 476.00

Minimum permeability (md): 0.02

Number of permeability analyses: 49

Dykstra-Parsons coefficient: na 


\section{BARRYTOWN FIELD}

SMACKOVER OIL POOL

CHOCTAW COUNTY, ALABAMA 


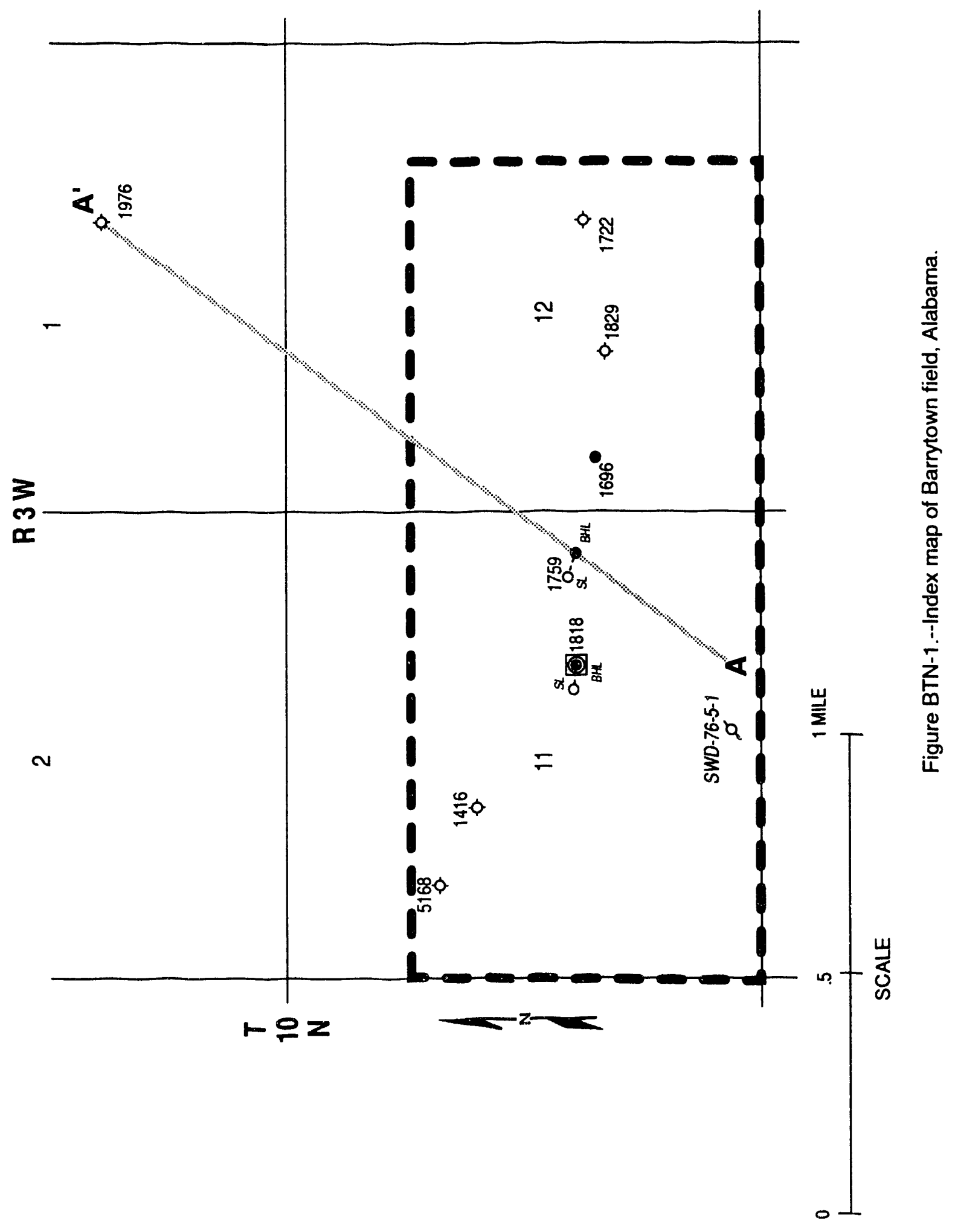




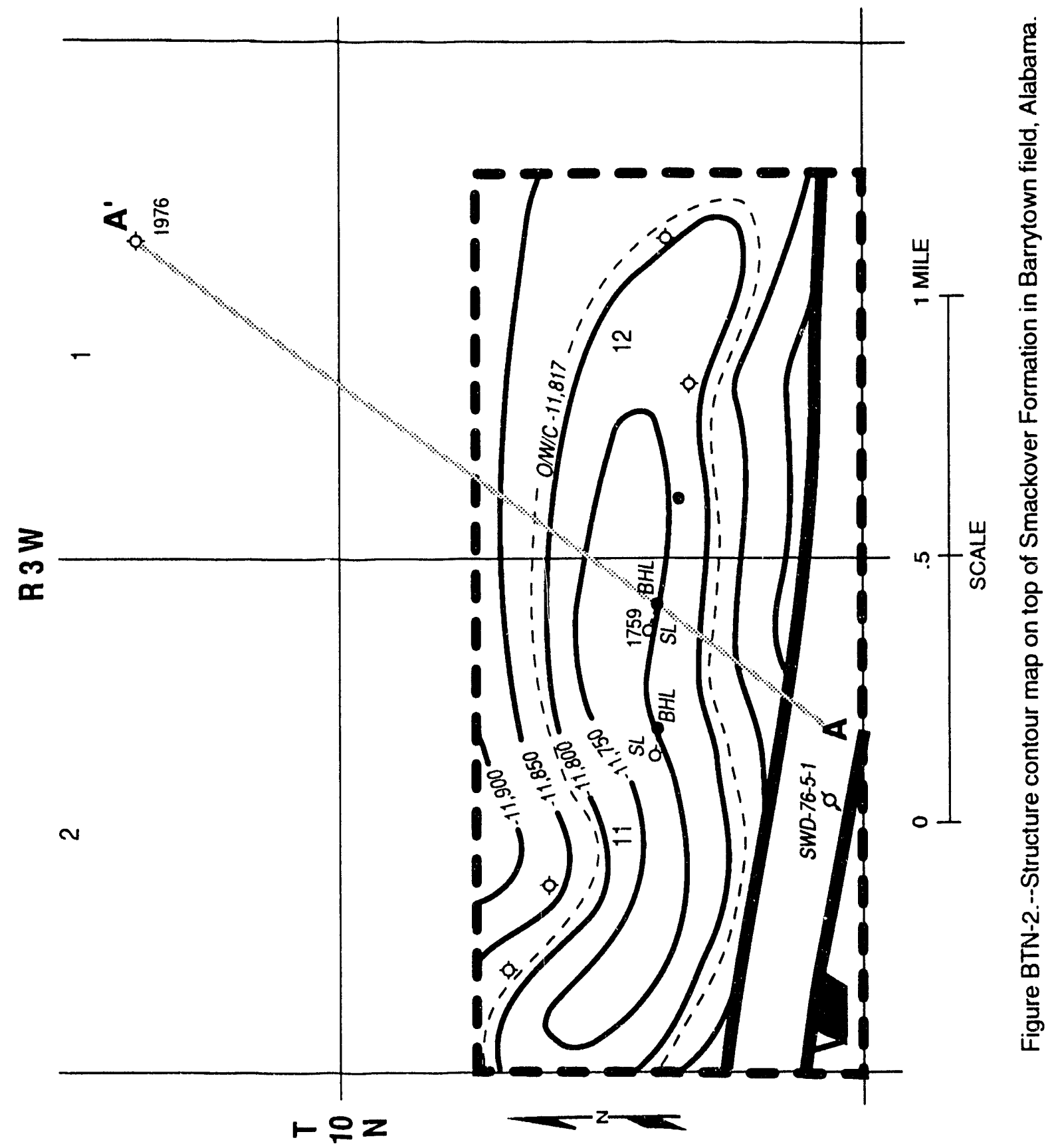




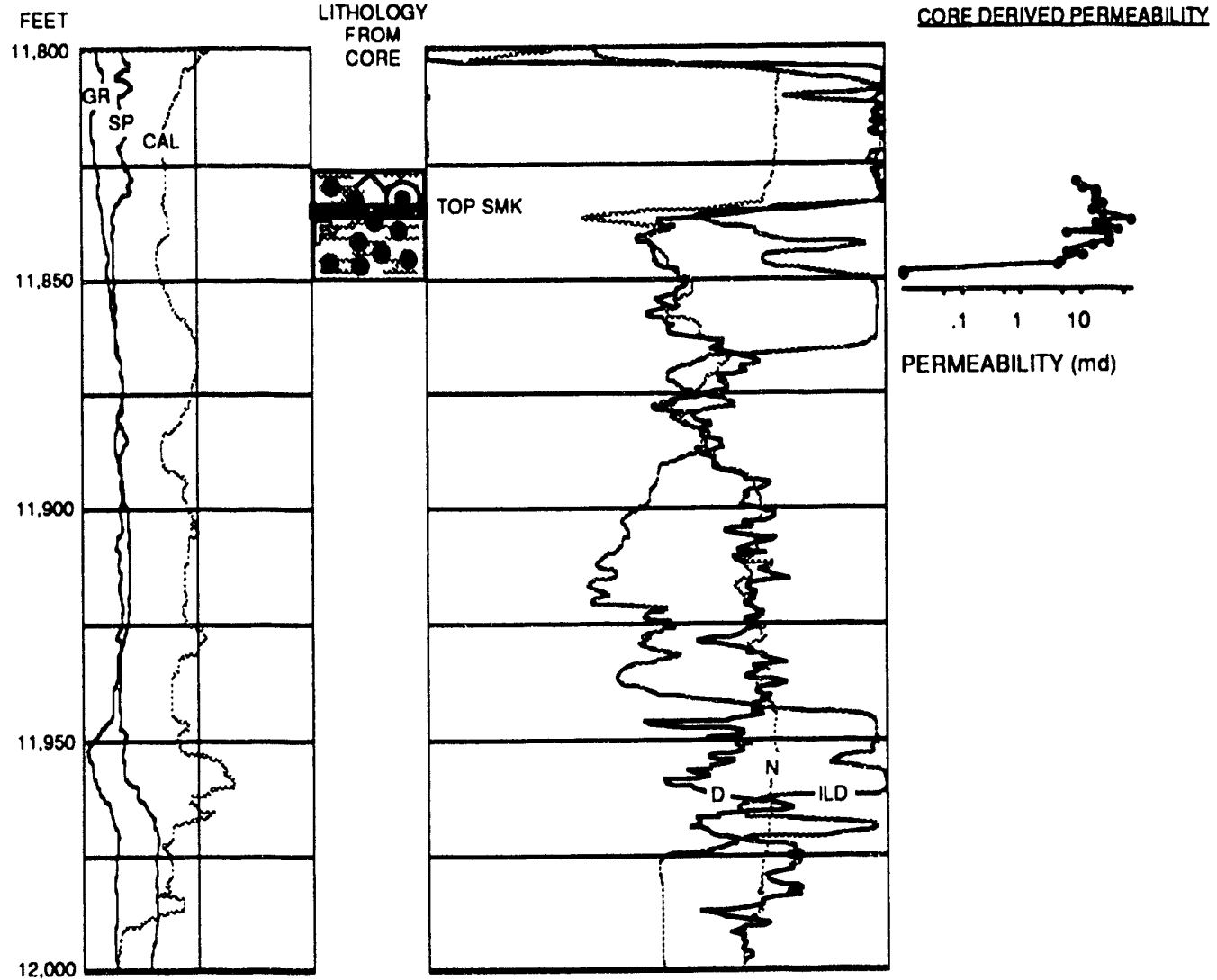

Figure BTN-3.--Well log correlated to lithology and permeability, Mclllwain 11-10 well, Permit No. 1818, Barrytown field, Alabama. 


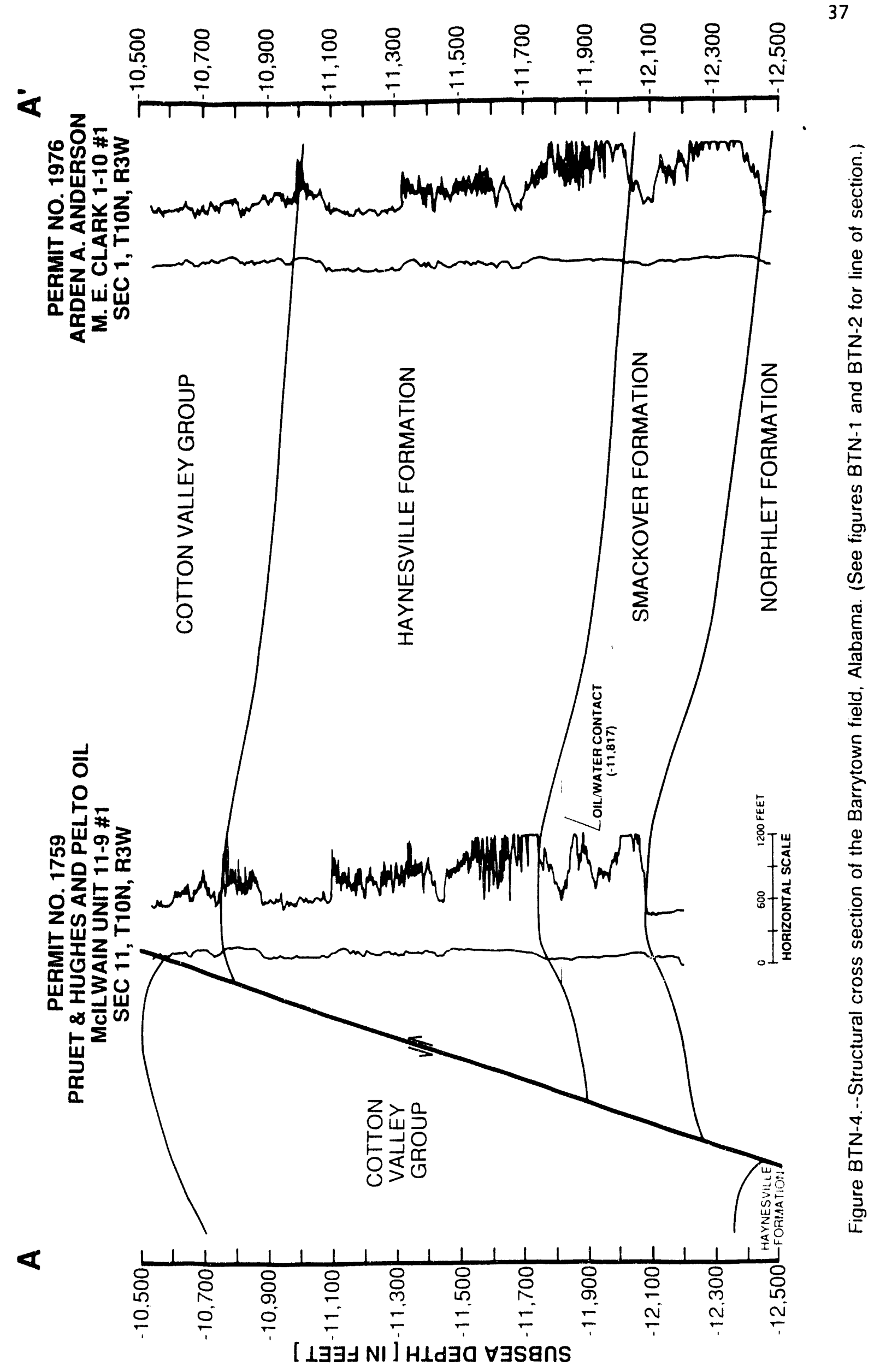




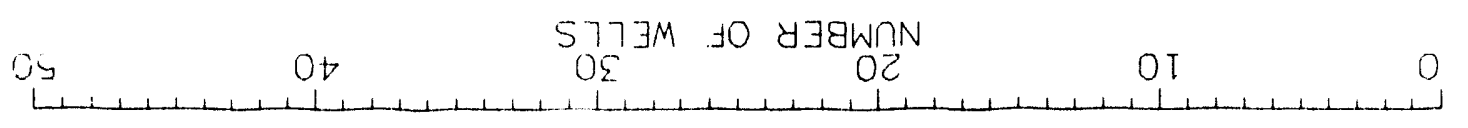

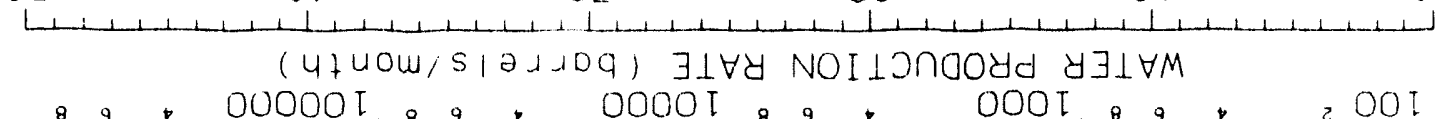

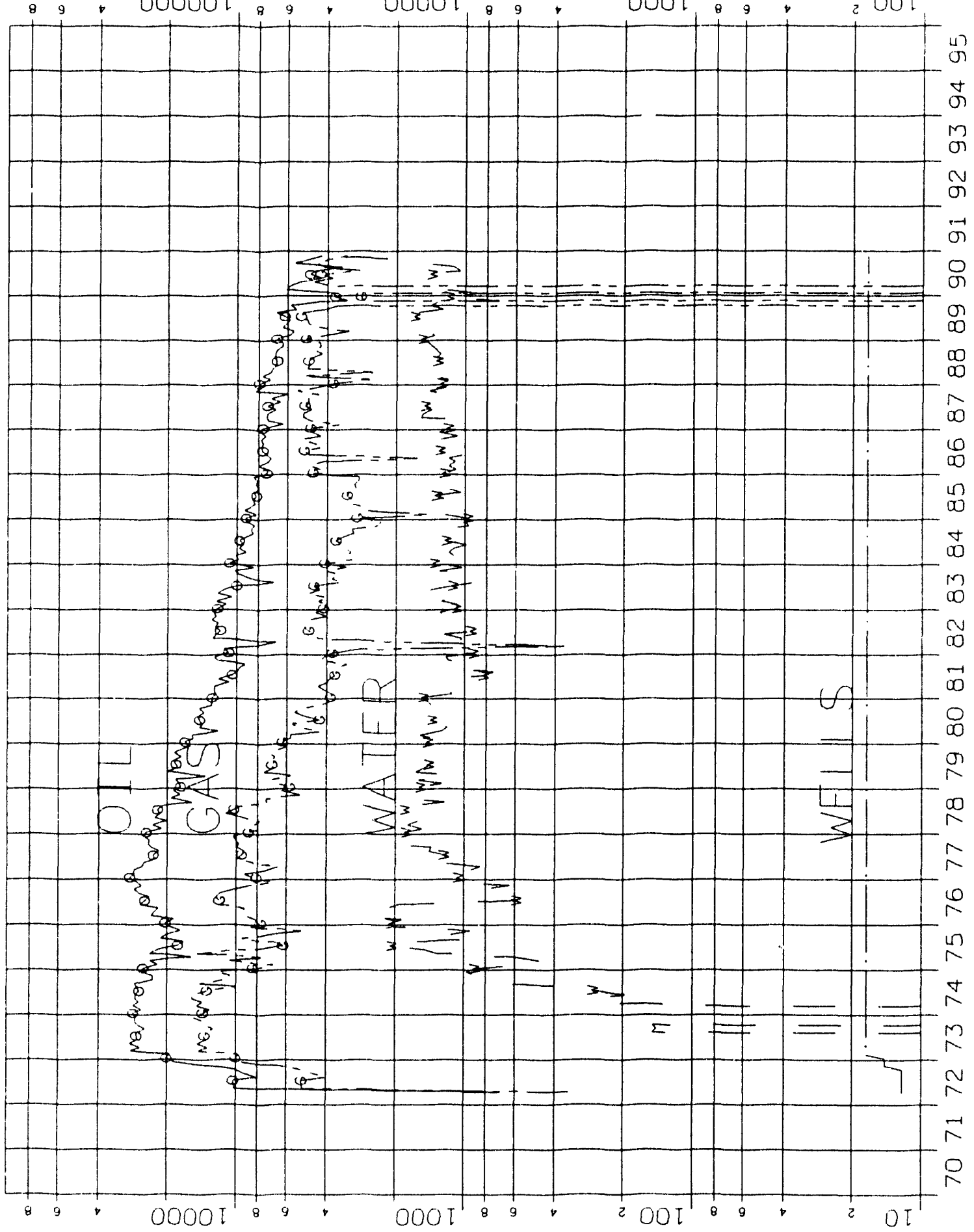

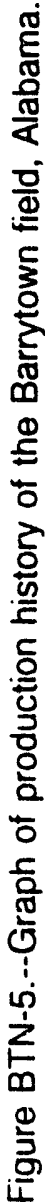

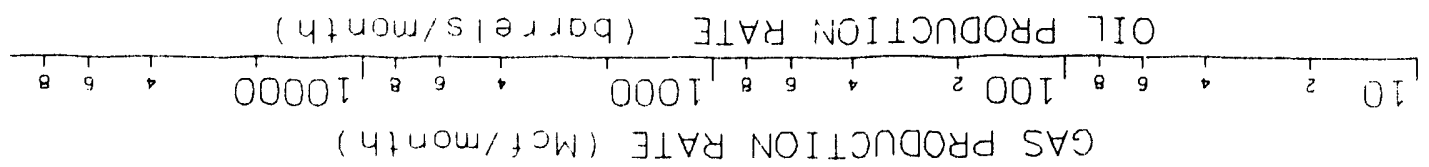


(a)

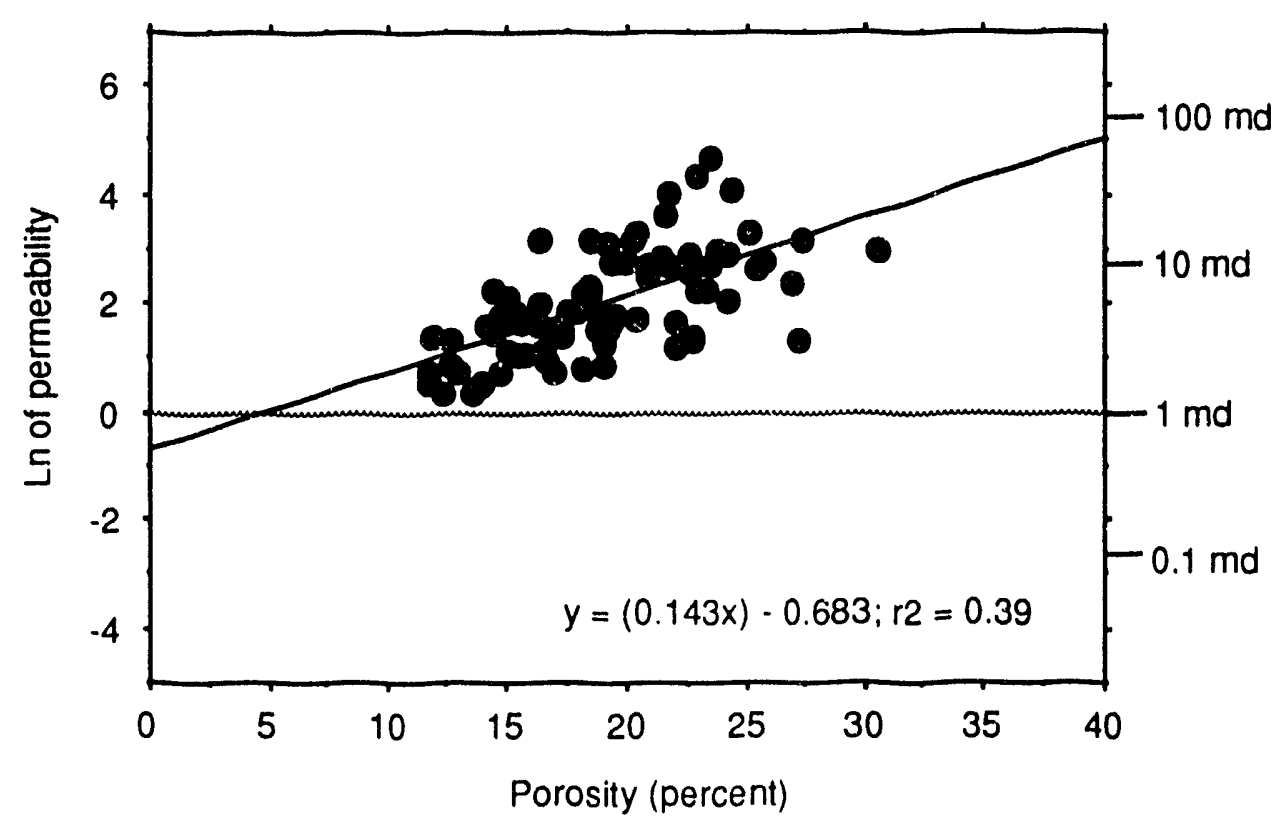

(b)

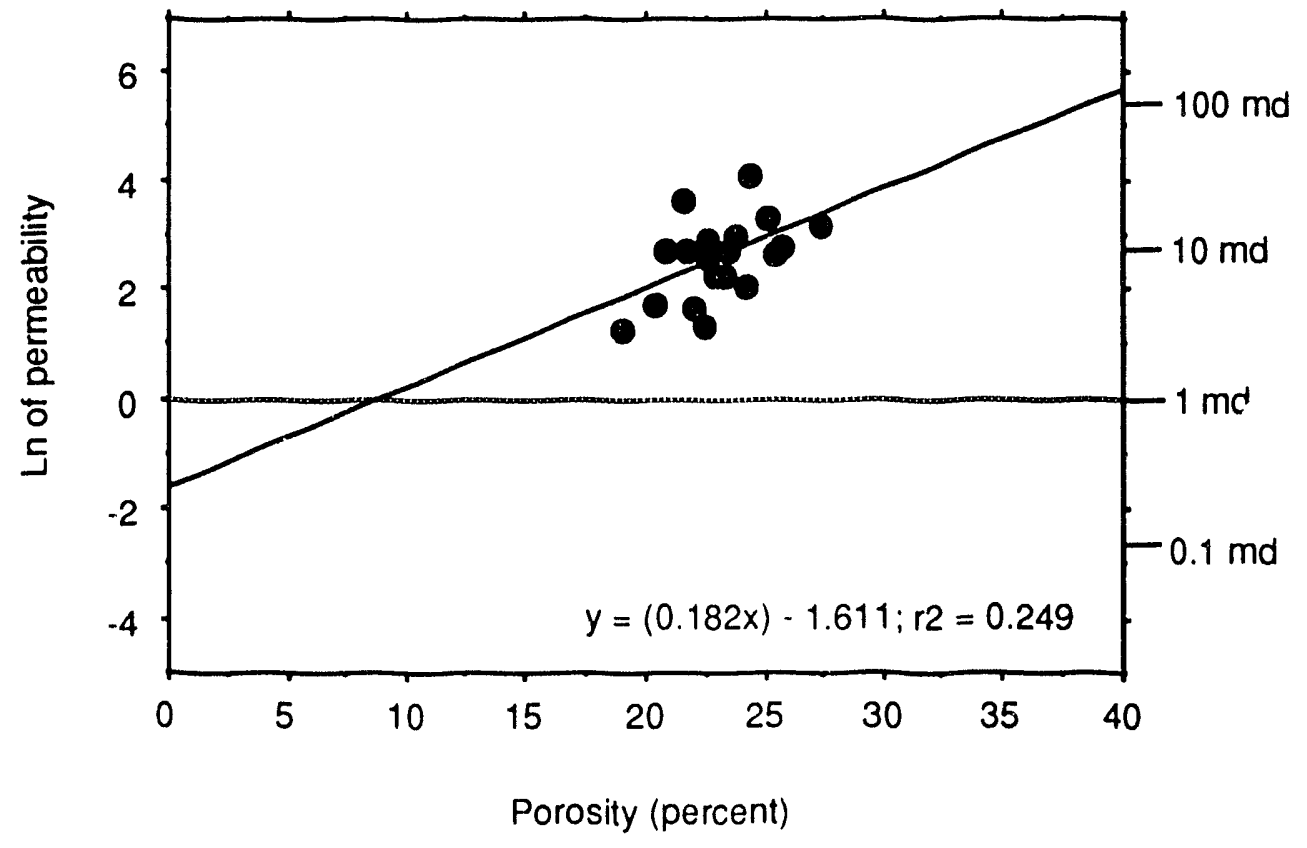

Figure BTN-6..-Porosity vs. natural log permeability plots. Barrytown field, Alabama. (a) Plot of two cores combined, and (b) plot of described core for Mclllwain 11-10 well, Permit No. 1818. Equations apply to regression lines. 
Table BTN-1.--Reservoir characterization sheet, Smackcver pool, Barrytown field, Choctaw County, Alabama

\section{Discovery well}

Operator: Pruet \& Hughes Co.

Permit number: 1696

Well Name: A.J. Phillips 12-2 \#1

Location: Sec. 12, T10N-R3W

Completion date: 03/25/72

Perforations: $11,830-11,840,11,848-11,8 € \mathrm{ft}$

Initial flow rate: 264 bopd, 132 Mcfd,

$$
1 / 4 \mathrm{ck}, 600 \mathrm{psi}
$$

Field data (as of 12/31/90)

Number \& wells within field !imits: 9

Producing wells in pool: 3

Production wells in field: 3

Shut-in/Temp. abandoned wells: 0

Plugged and abandoned wells: 4

Salt water disposal wells: 1

Enhanced recovery wells: 0

Dry holes: 0

Drilling wells: 1

Unit spacing ('dcres): 120

Total field area (acres): 840

Cumulative production

Oil (bbl): $3,171,350$

Gas (Mcf): 1,335,890

Water (bbl): $2,571,118$

\section{Reservoir data}

Trap type: Structural / stratigraphic Reservoir structure: Faulted anticline Proven productive area (acres): 554 Average net pay thickness (feet): 43 Hydrocarbon type: Oil

Oil gravity (API): 45 Initial resenoir pressure (psia): na Current reservoir pressure (psia): na Reservoir drive: Solution gas / water Type of enhanced recovery: none Mean porosity (core) (\%): 15.44 Porosity standard deviation (\%): 4.14 Maximum porosity (\%): 24.20 Minimum porosity (\%): 5.70 Number of porosity analyses: 48 Geometric mean perm (core) (md): 6.61 Maximum permeability (md): 109.00 Minimum permeability (md): 1.50 Number of permeability analyses: 38 Dykstra-Parsons coefficient: na 


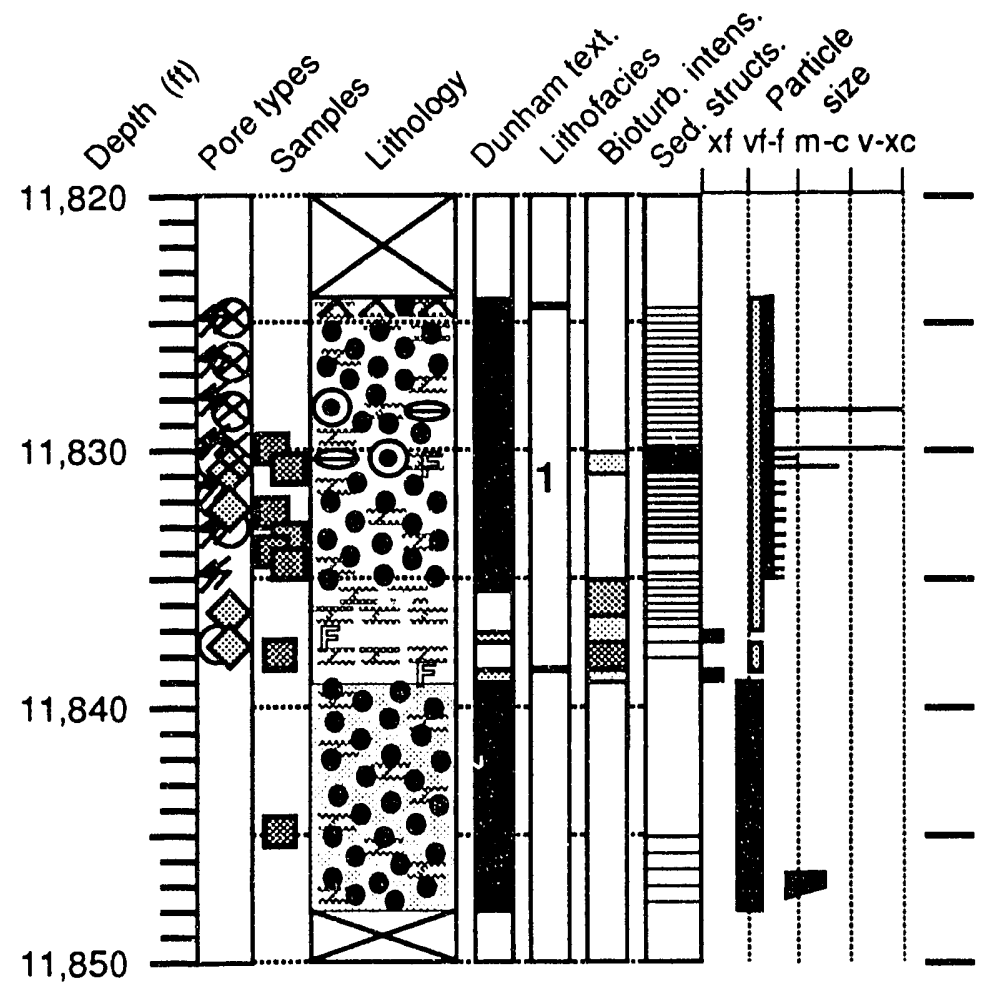

Figure BTN-7.--Detailed core log, Mcllwain 11-10 No. 1 well, Permit No. 1818, Barrytown field, Alabama. 
Table BTN-2.--Lithofacies description of core from Mcllwain 11-10 No. 1 well, Permit No. 1818, Barrytown field, Alabama (see figure BTN-7)

Lithofacies 1: Dolomitic pellet grainstone with minor crystalline dolostone

Pore types:

Moldic: $30 \%$

Fracture: $28 \%$

Intercrystalline: $25 \%$

Secondary Intraparticle: $17 \%$

Mean porosity (\%): 23.3

Maximum porosity (\%): 27.3

Minimum porosity (\%): 20.7

Porosity standard deviation (\%): 1.8

Number of analyses: 13

Geometric mean permeability (md): 16.65

Maximum permeability (md): 59.40

Minimum permeability (md): 5.4

Number of analyses: 13

Depositional Environment: Tidal flat, mostly subtidal.

Diagenesis: Early formation of lithified nodules and crusts, and the fracturing of these nodules or crusts, partial dolcmitization, minor leaching of particles.

Percent of reservoir: 100

Depth interval(s) (ft): $11,824-11,838.5$ 


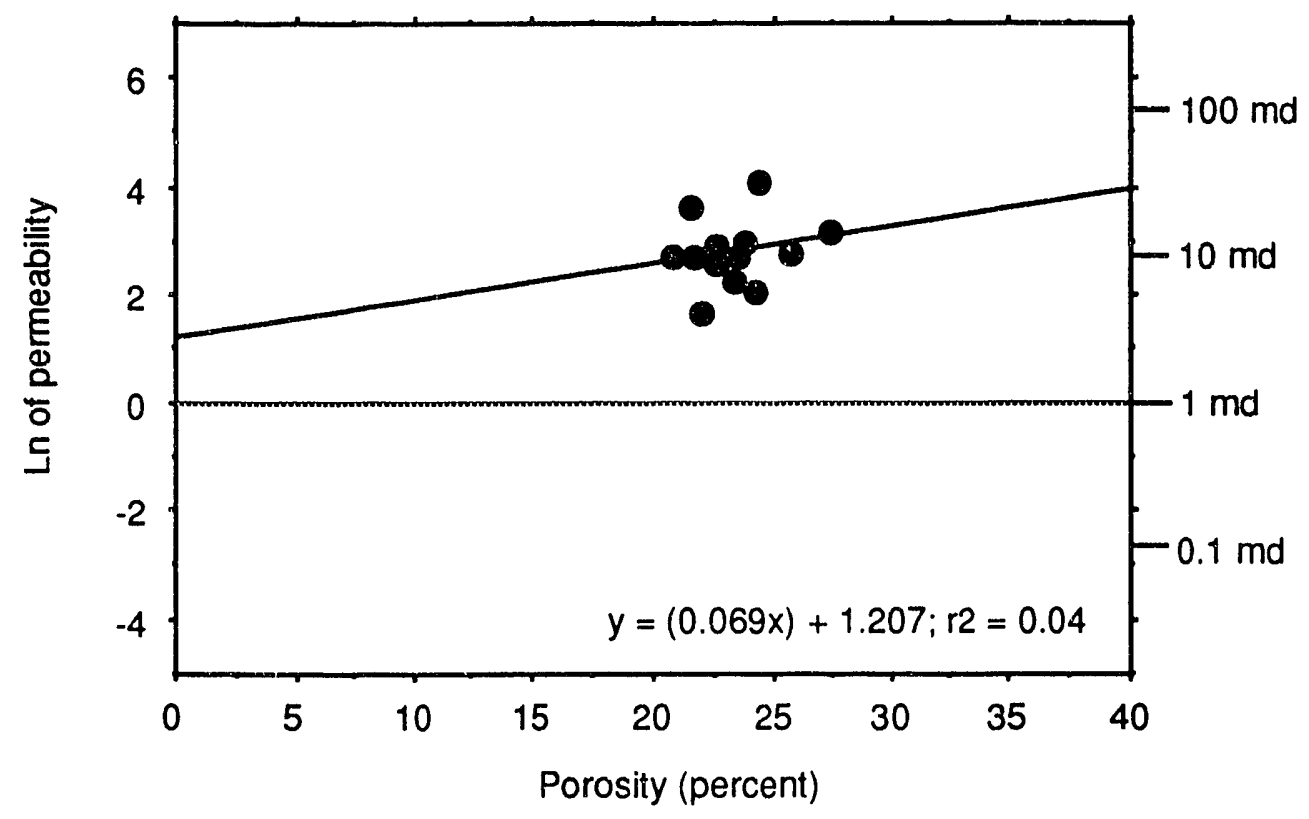

Figure BTN-8.--Porosity vs. natural log permeability plot for lithofacies 1, Mclliwain 11-10 No. 1 well, Permit No. 1818, Barrytown field, Alabama. Equation applies to regression line. (See table BTN-2 for descriptions of lithofacies. 


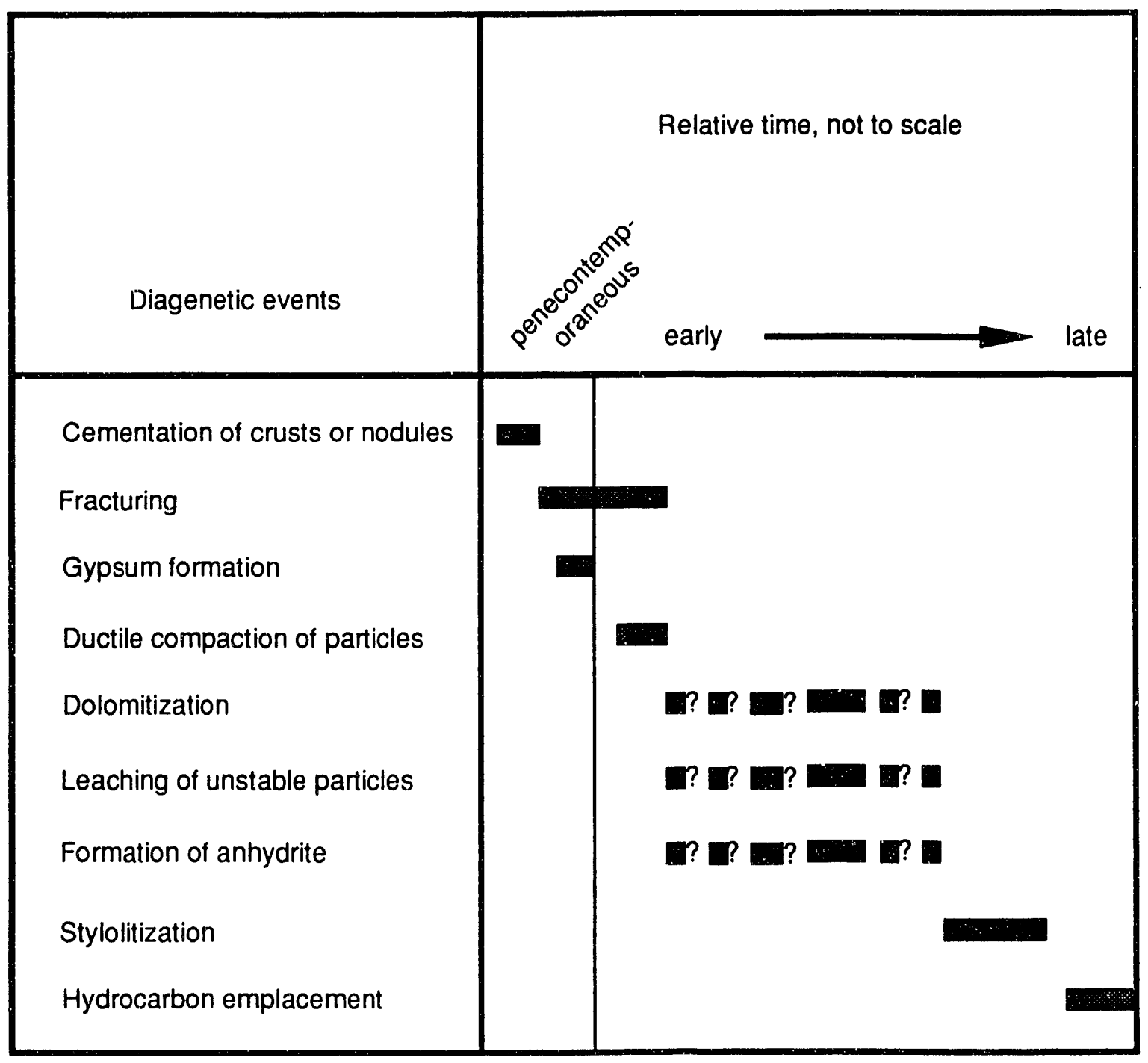

Figure BTN-9.--Paragenetic sequence, Mcllwain 11-10 No. 1 well, Permit No. 1818, Barrytown field, Alabama. 


\title{
BIG ESCAMBIA CREEK FIELD
}

\section{SMACKOVER GAS AND CONDENSATE POOL}

\author{
ESCAMBIA COUNTY, ALABAMA
}




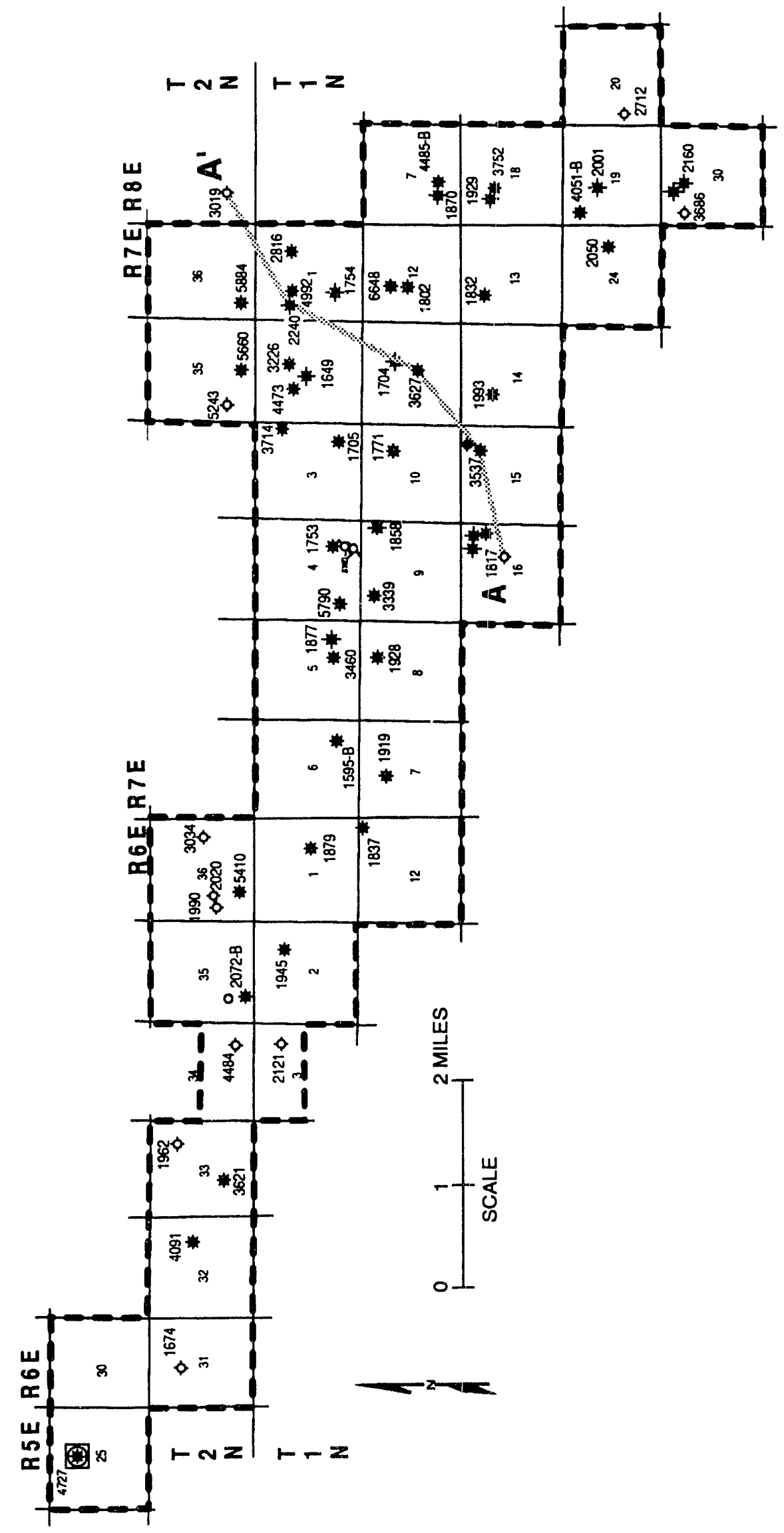

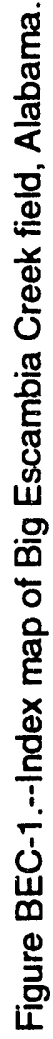




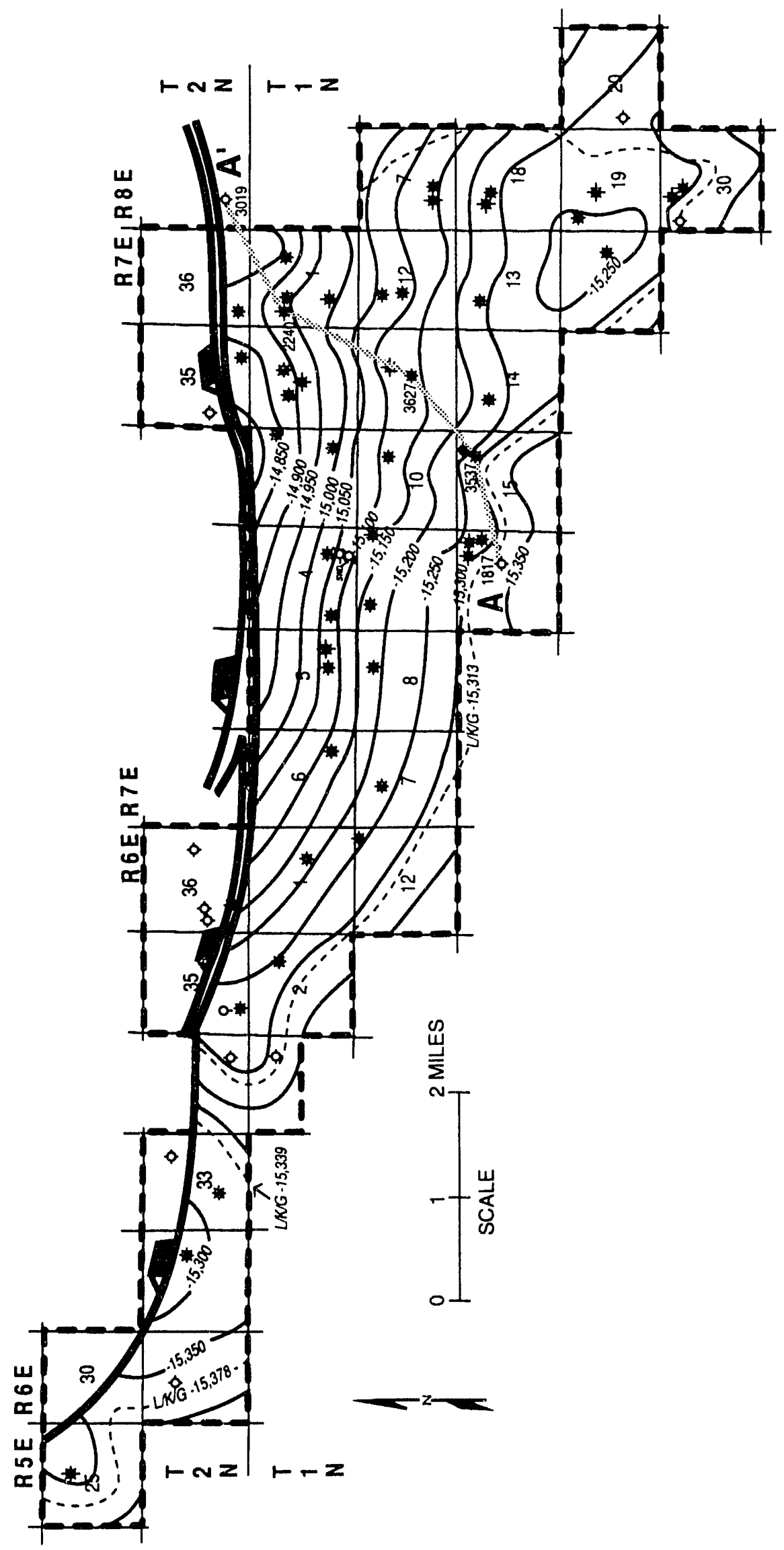

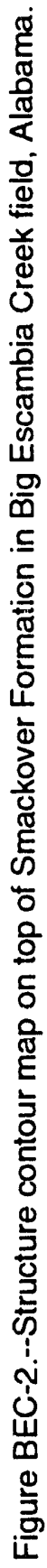




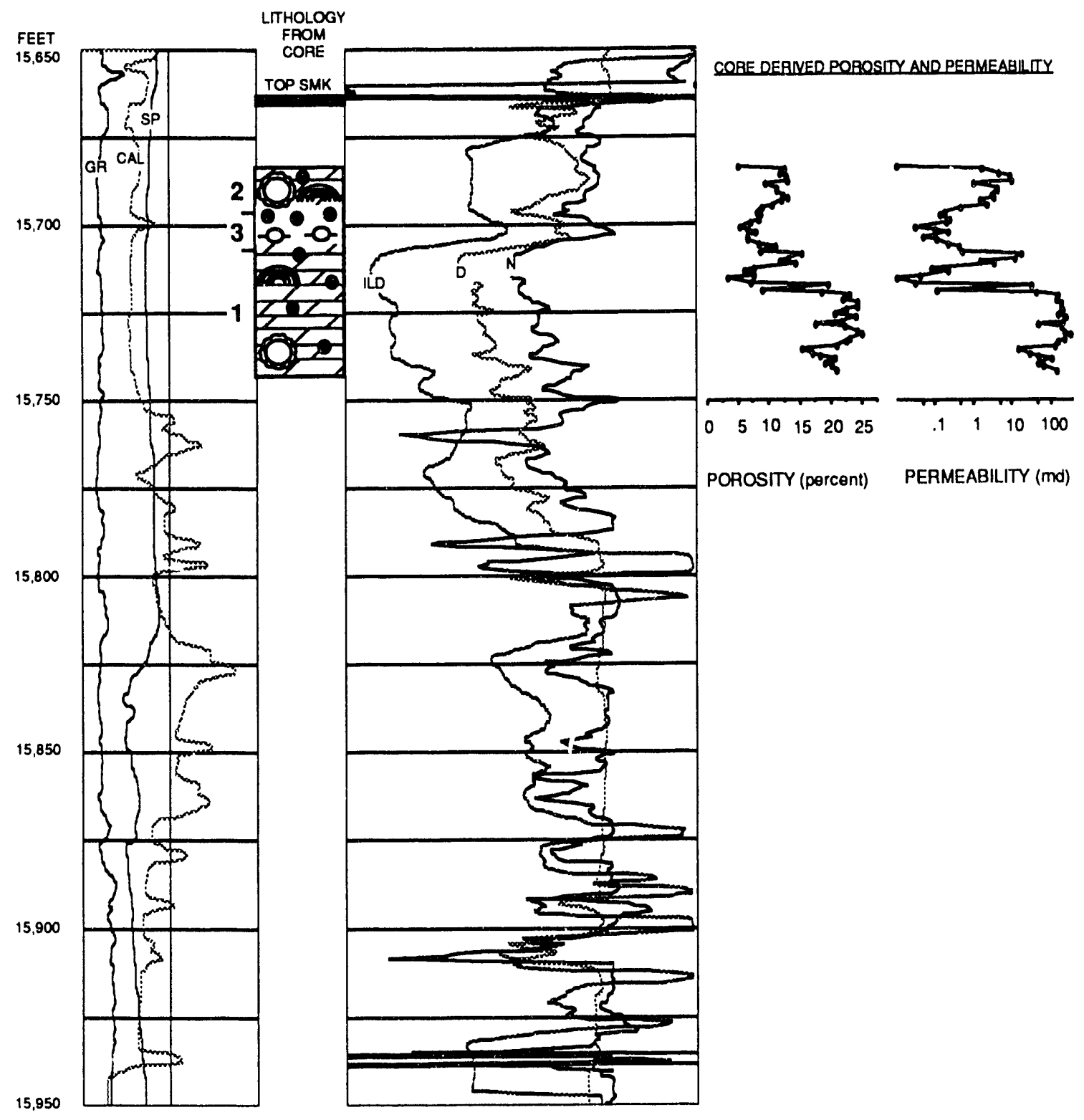

Figure BEC-3.--Well log correlated to lithology, porosity, and permeability, Smith 25-7 No. 1 well, Permit 4727, Big Escambia Creek field, Alabama. 


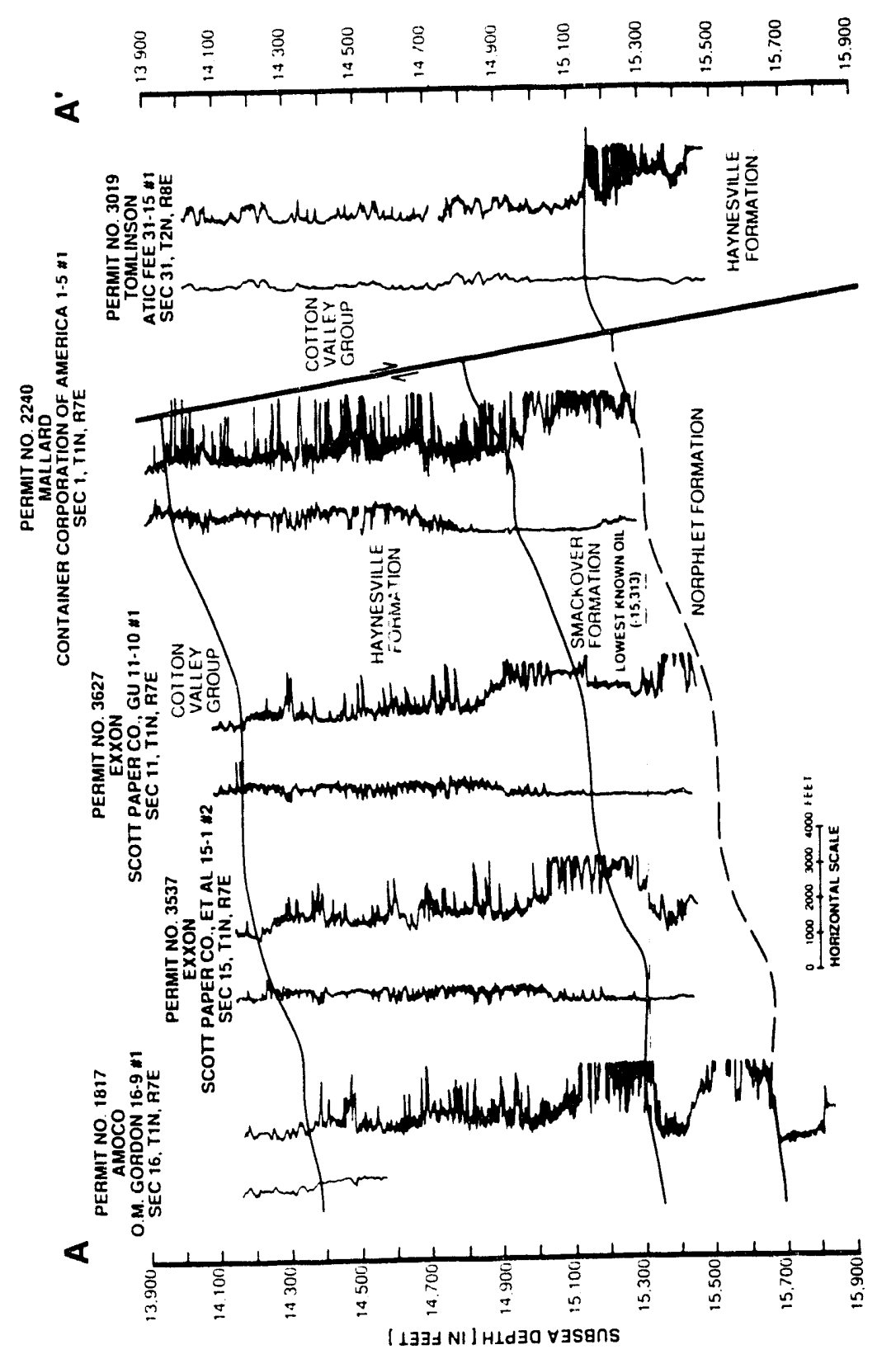

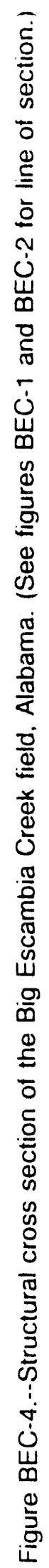




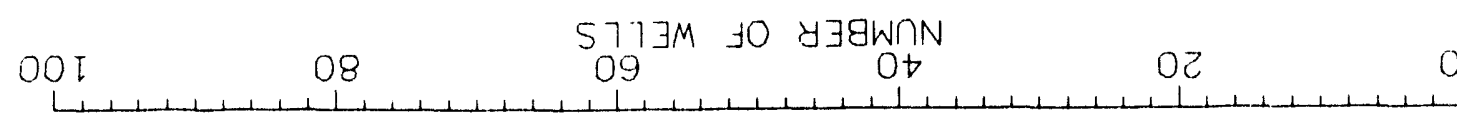

( $4+40 w / s \mid \partial \lambda .10 q) \quad \exists \perp \forall Y$ NOI $\perp$ JnoOdd $y \exists \perp \forall M$

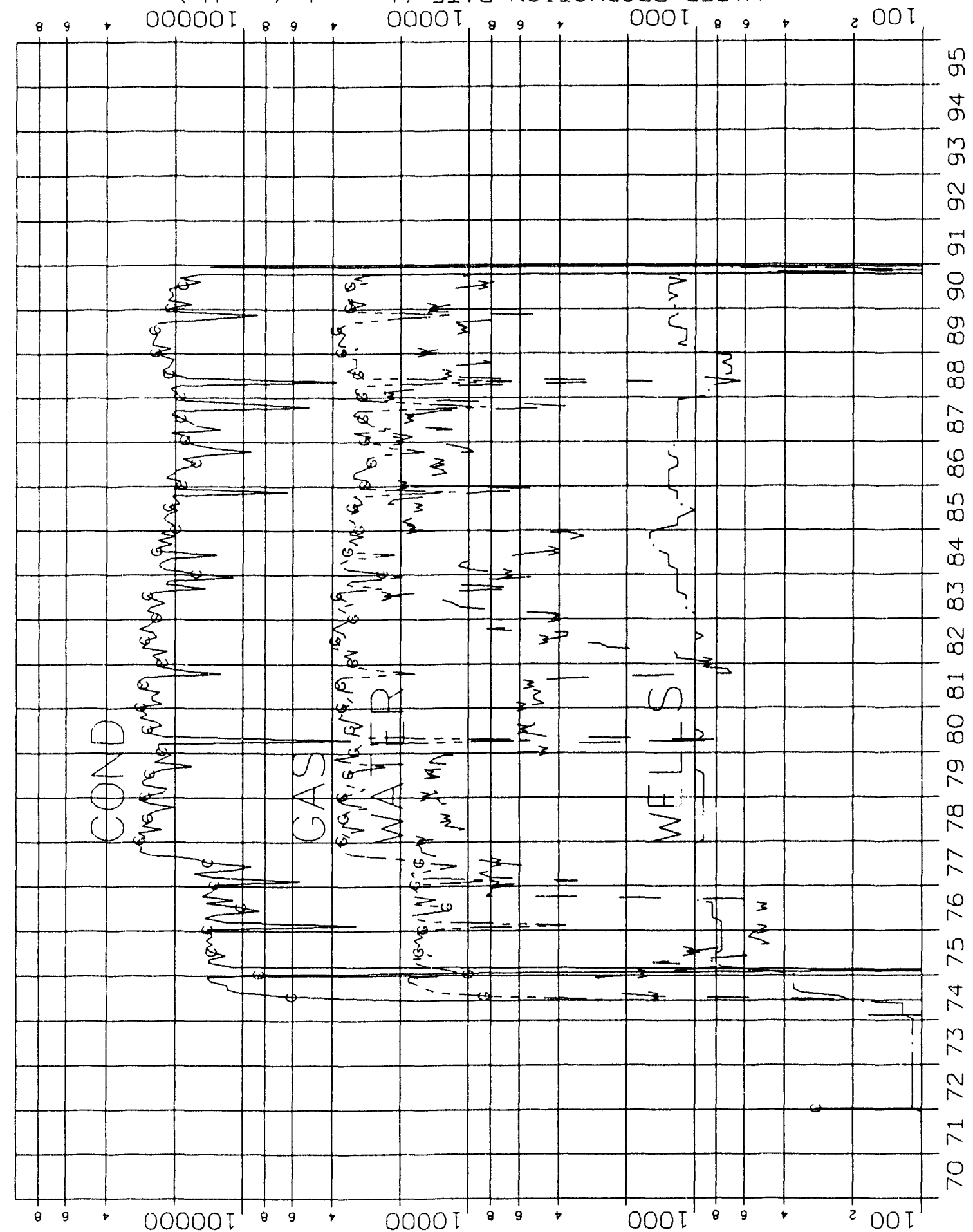

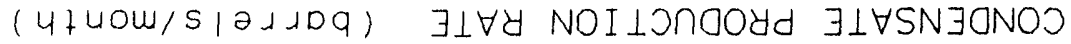

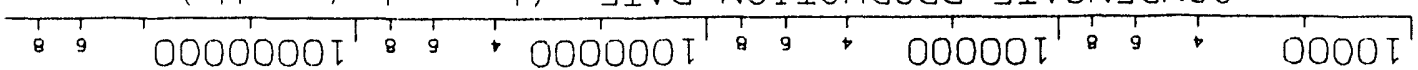

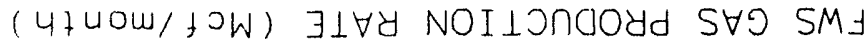


(a)

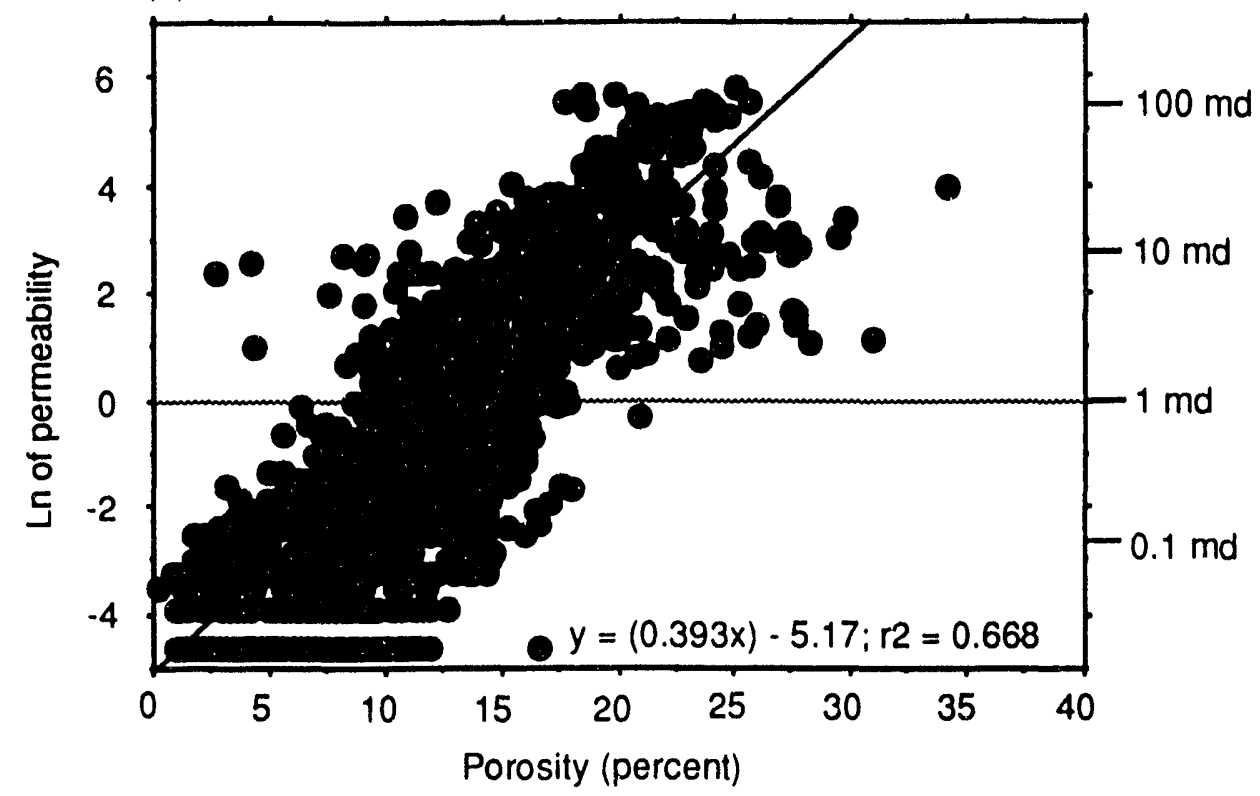

(b)

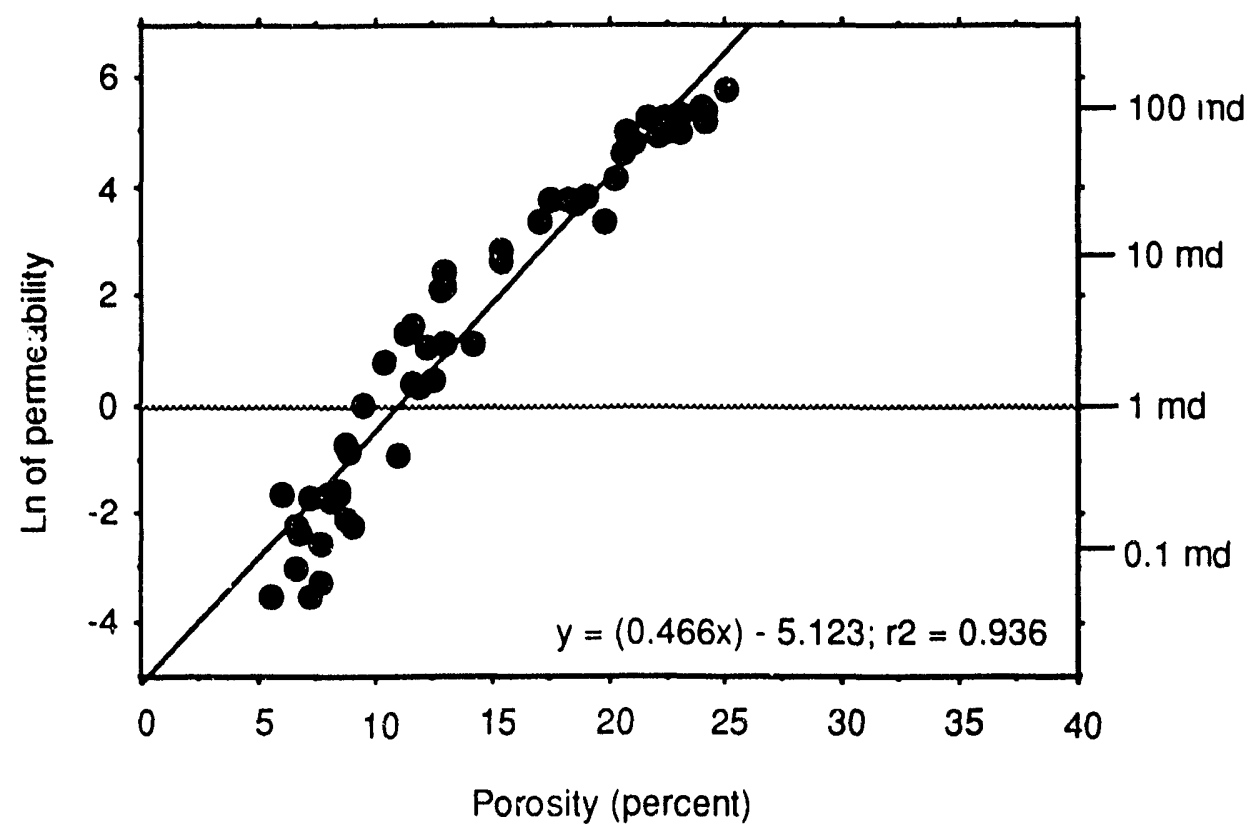

Figure BEC-6..-Porosity vs. natural log permeability plots, Big Escambia Creek field, Alabama. (a) Plot of 27 cores combined, and (b) plot of described core for Smith 25-7 No. 1 well, Permit No. 4727. Equations apply to regression lines. 
Table BEC-1.--Reservoir characterization sheet, Smackover pool, Big Escambia Creek field, Escambia County, Alabama

\section{Discovery well}

Operator: Mallard Exploration, Inc.

Permit number: 1649

Well Name: Int. Paper Co. et al Unit 2-6 \#1

Location: Sec. 2, T1N-R7E

Completion date: 12/17/71

Perforations: $15,090-15,106,15,142-15,178 \mathrm{ft}$

Initial flow rate: 332 bcpd, 5,891 mcfd,

17/64 ck, 3700 psi

Field data (as of 12/31/90)

Number of wells within field limits: 52

Producing wells in pool: 26

Production wells in field: 26

Shut-in/Temp. abandoned wells: 1

Plugged and abandoned wells: 19

Salt water disposal wells: 2

Enhanced recovery wells: 0

Dry holes: 4

Drilling wells: 0

Unit spacing (acres): 640

Total field area (acres): 20,480

Cumulative production

Condensate (bbl): $38,623,880$

Gas (mcf): 552,626,786

Water (bbl): 1,252,215

\section{Reservolr data}

Trap type: Structural / Stratigraphic

Reservoir structure: Faulted Monocline

Proven productive area (acres): 15,858

Average net pay thickness (feet): 63

Hydrocarbon type: Gas Condensate

Oil gravity (API): 46

Initial reservoir pressure (psia): 7,662

Current reservoir pressure (psia): 3,258

Reservoir drive: Depletion

Type of enhanced recovery: none

Mean porosity (core) (\%): 12.00

Porosity standard deviation: $\mathbf{5 . 2 0}$

Maximum porosity (\%): 34.10

Minimum porosity (\%): 0.20

Number of porosity analyses: 1,648

Geometric mean perm (core) (md): 0.64

Maximum permeability (md): 344

Minimum permeability (md): 0.01

Number of permeability analyses: 1,648

Dykstra-Parsons coefficient: na 


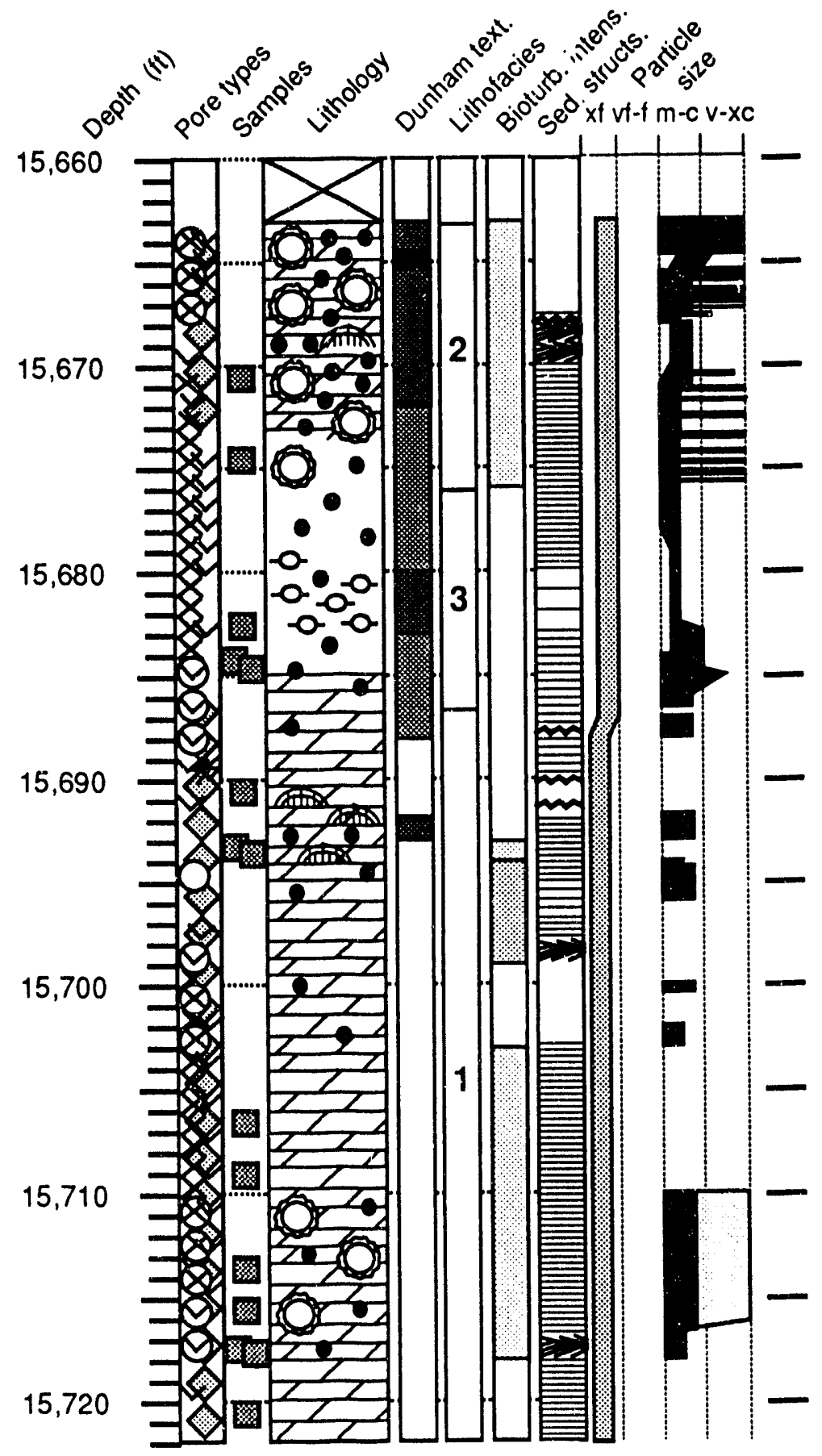

Figure BEC-7-.-Detailed core log, Smith 25-7 No. 1 well, Permit No. 4727, Big Escambia Creek field, Alabama. 
Table BEC-2.--Lithofacies description of core from Smith 25-7 No. 1 well, Permit No. 4727, Big Escambia Creek field, Alabama (see figure BEC-7)

Lithofacies Peloid dolowackestone

Pore types:

Intercrystalline: $65 \%$

Vuggy: $16 \%$

Secondary intraparticle: $10 \%$

Moldic: $8 \%$

Fracture: $1 \%$

Mean porosity (\%): 17.8

Maximum porosity (\%): 25.0

Minimum porosity (\%): 6.0

Porosity standard deviation (\%): 5.8

Number of analyses: 34

Geometric mean permeability (md): 21.82

Maximum permeability (md): 344.00

Minimum permeability (md): 0.03

Number of analyses: 34

Depositional Environment: Shallow subtidal restricted low-energy shelf, probably a sheltered lagoon behind a high-energy shoal.

Diagenesis: Dolomitization, leaching, late calcite cementation and lesser dolomite cementation in vugs (and molds). Pressure solution seems to predate at least some dolomitization, and follows fracture formation.

Percent of Reservoir: 61

Depth interval(s) (ft): $15,687-15,721.5$

Lithofacies 2: Oncoidal peloid dolopackstone/grainstone, dominated by thin shoaling-upward cycles

Pore types:

Intercrystalline: $35 \%$

Secondary intraparticle: $35 \%$

Vuggy: $19 \%$

Moldic: $11 \%$

Mean porosity (\%): 11.5

Maximum porosity (\%): 13.0

Minimum porosity (\%): 8.8

Porosity standard deviation (\%): 1.3

Number of analyses: 12 
Table BEC-2.--Lithofacies description of core from Smith 25-7 No. 1 well, Permit No. 4727, Big Escambia Creek field, Alabama (see figure BEC-7) -- Continued

Geometric mean permeability (md): 2.65

Maximum permeability $(\mathrm{md}): 9.20$

Minimum permeability (md): 0.45

Number of analyses: 12

Depositional Environment: Moderate energy shallow-marine restricted shelf, probably lower tidal flat in partially sheltered area, local beach development.

Diagenesis: Dolomitization, leaching, late calcite cementation and anhydrite cementation in molds and vugs. Pressure solution seems to predate at least some dolomitization.

Percent of re servoir: 22

Depth interval(s) (ft): $15,663-15,676$

Lithofacies 3: Partially dolomitized coated-grain peloid wackestone and packstone

Pore types:

Secondary intraparticle: $43 \%$

Vuggy: $27 \%$

Intercrystalline: $23 \%$

Moldic: $7 \%$

Mean porosity (\%): 7.7

Maximum porosity (\%): 11.0

Minimum porosity (\%): 5.4

Porosity standard deviation (\%): 1.5

Number of analyses: 11

Geometric mean permeability (md): 0.14

Maximum permeability (md): 0.43

Minimum permeability (md): 0.03

Number of analyses: 11

Depositional Environment: Low energy to moderate energy shallow marine restricted shelf, probable lagoon behind high-energy barrier (some Favreina pellets observed).

Diagenesis: Dolomitization, leaching, late calcite cementation in vugs.

Percent of reservoir: 17

Depth interval(s) (ft): $15,676-15,687$ 
(a)

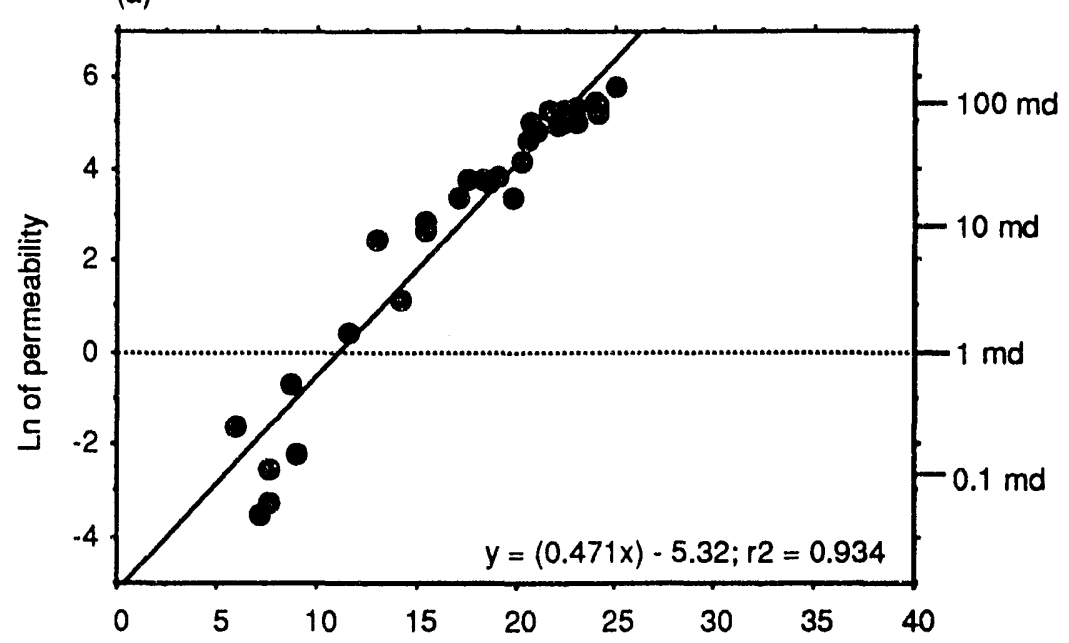

(b)

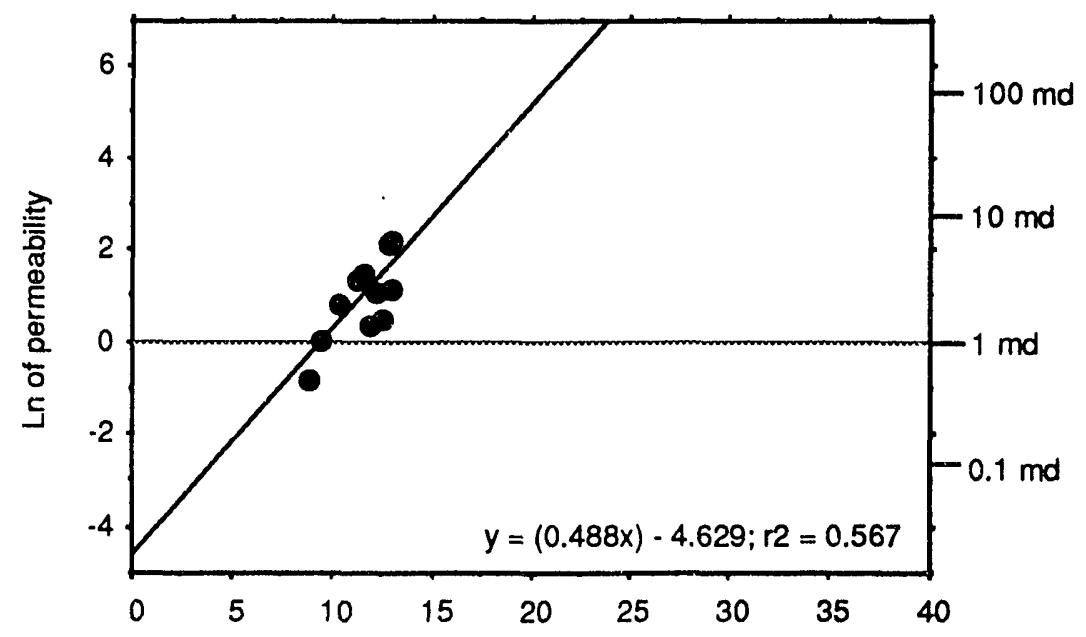

(c)

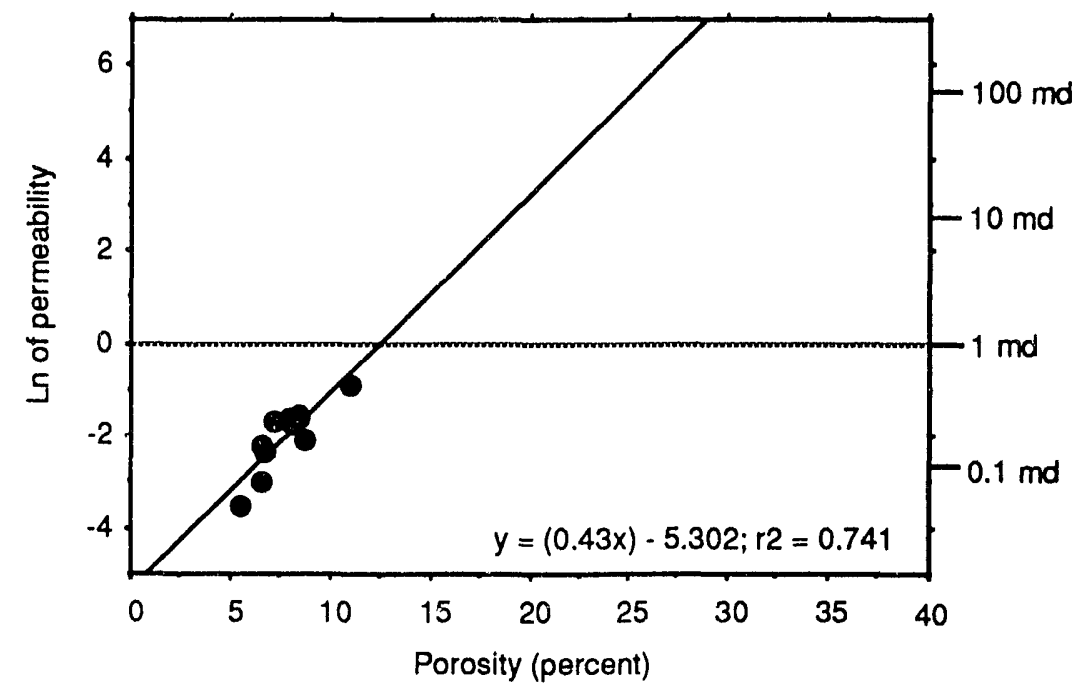

Figure BEC-8.--Porosity vs. natural log permeability plots for three lithofacies, Smith 25-7 No. 1 well, Permit No. 4727 Big Escambia Creek field, Alabama. (a) Lithofacies 1, (b) lithofacies 2, (c) lithofacies 3. Equations for regression lines are printed for each lithofacies. (See table BEC-2 for descriptions of lithofacies.) 


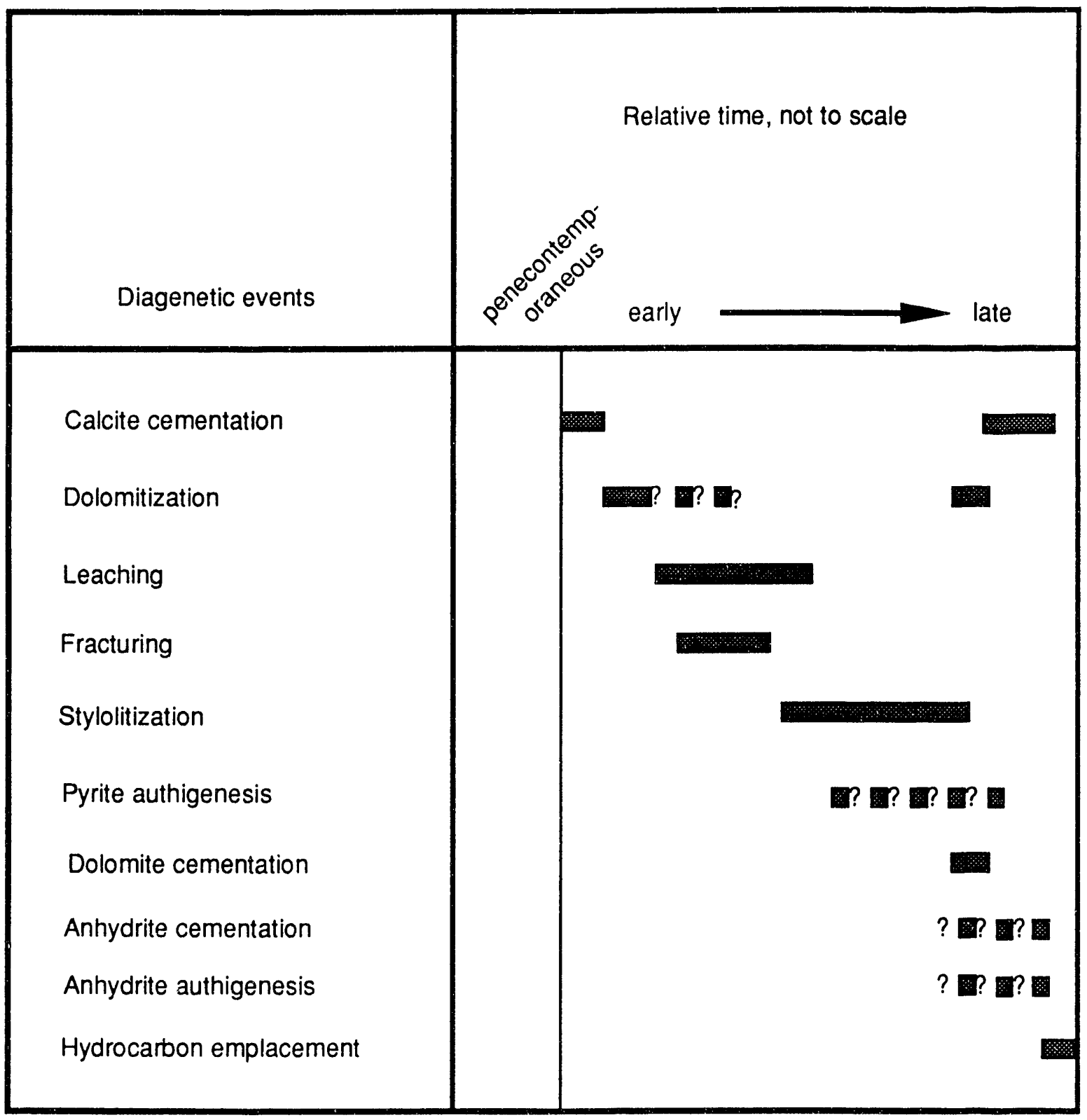

Figure BEC-9.--Paragenetic sequence, Smith 25-7 No. 1 well, Permit No. 4727, Big Escambia Creek field, Alabama. 


\section{BLACKSHER FIELD}

\section{SMACKOVER OIL POOL}

BALDWIN COUNTY, ALABAMA 


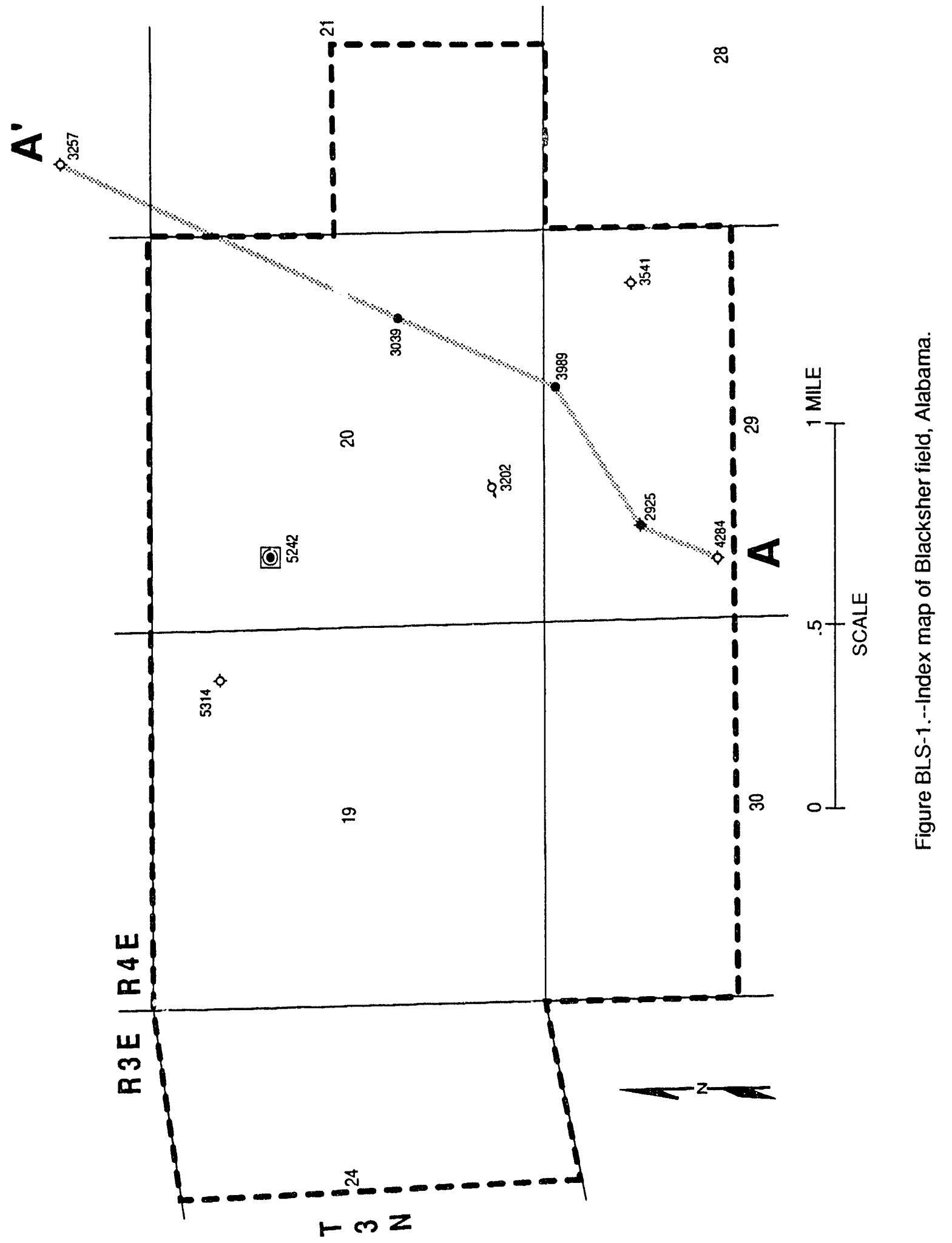


60

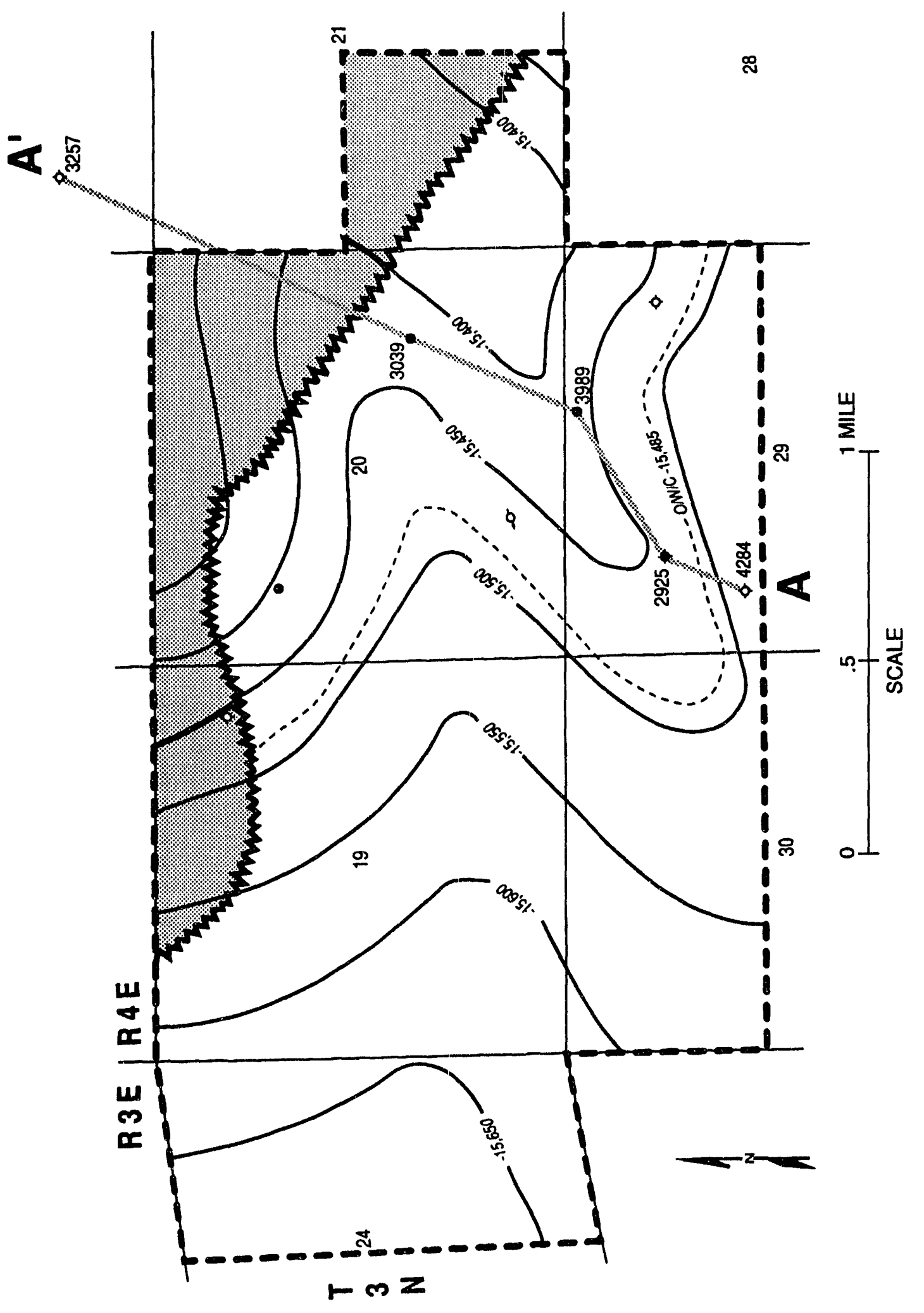

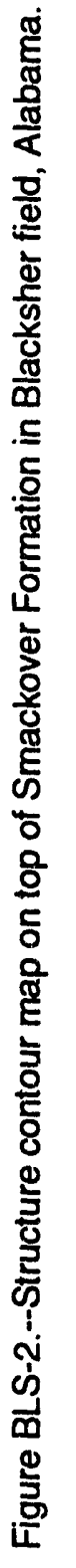




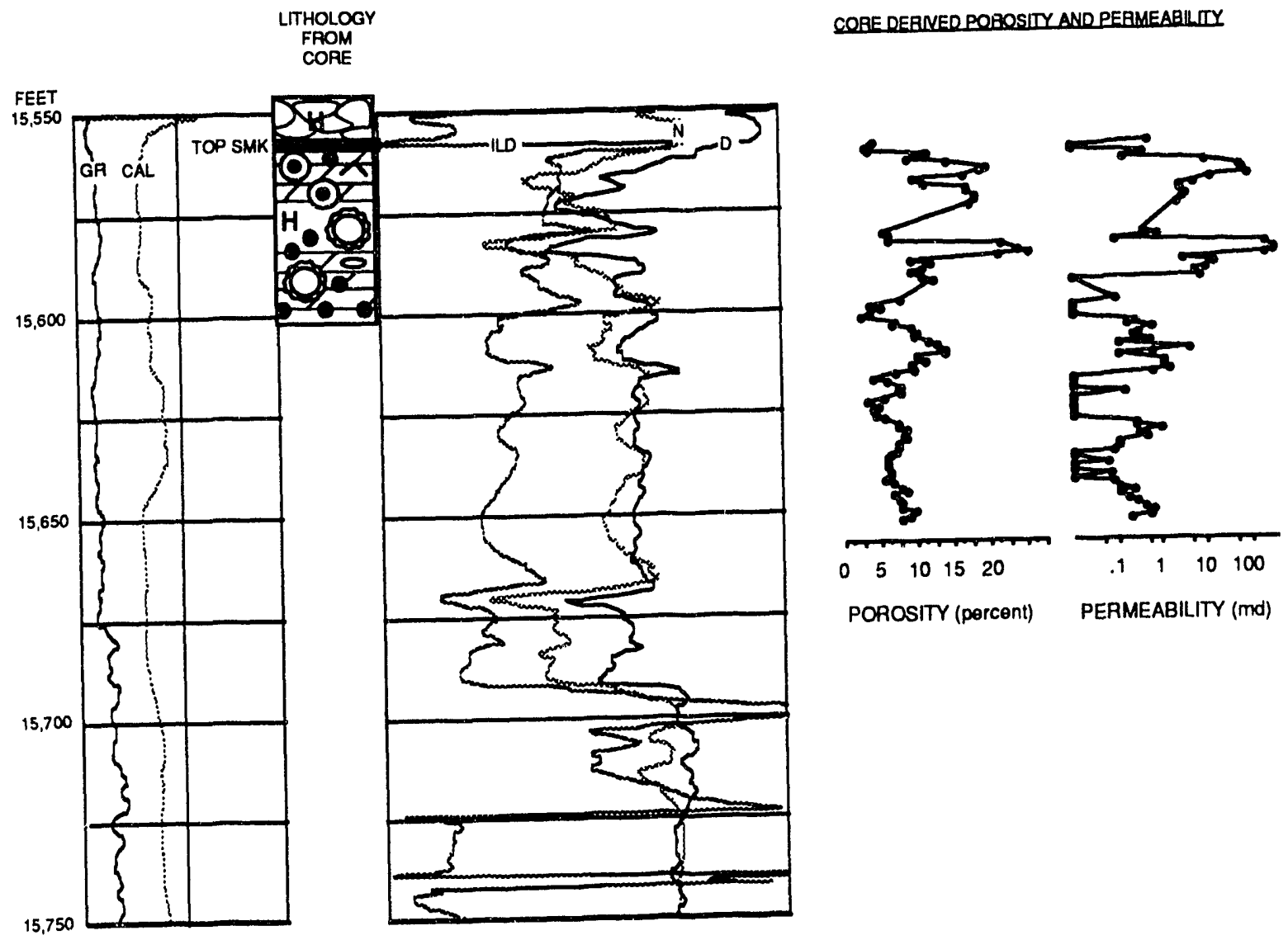

Figure BLS-3.--Well log correlated to lithology, porosity, and permeability, International Paper Co. 20-5 No. 1 well, Permit No. 5242, Blacksher field, Alabama. 


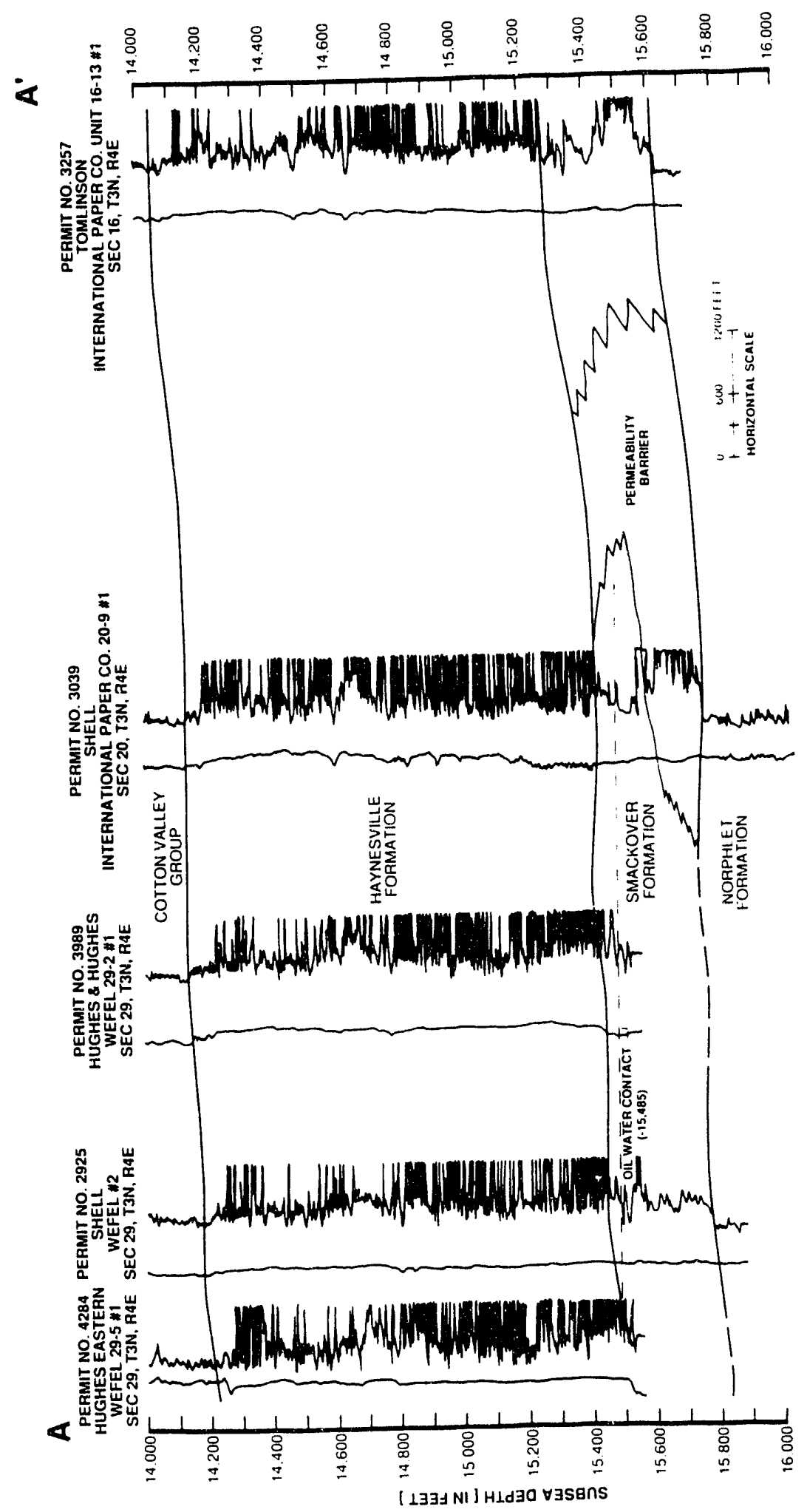

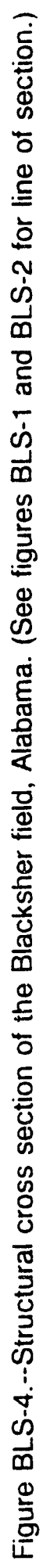



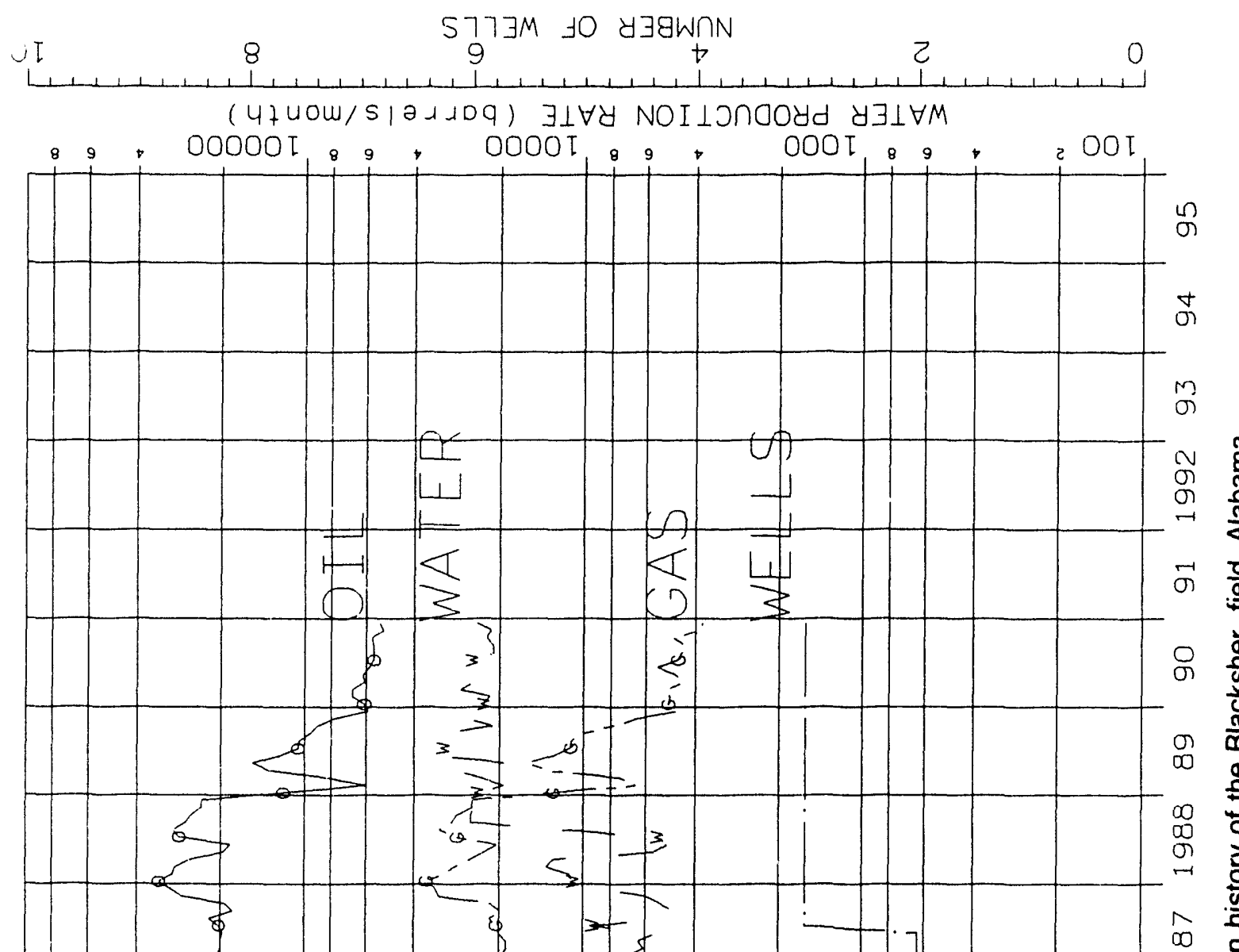

$\infty$
$\infty$
$\infty$
$\infty$
-1
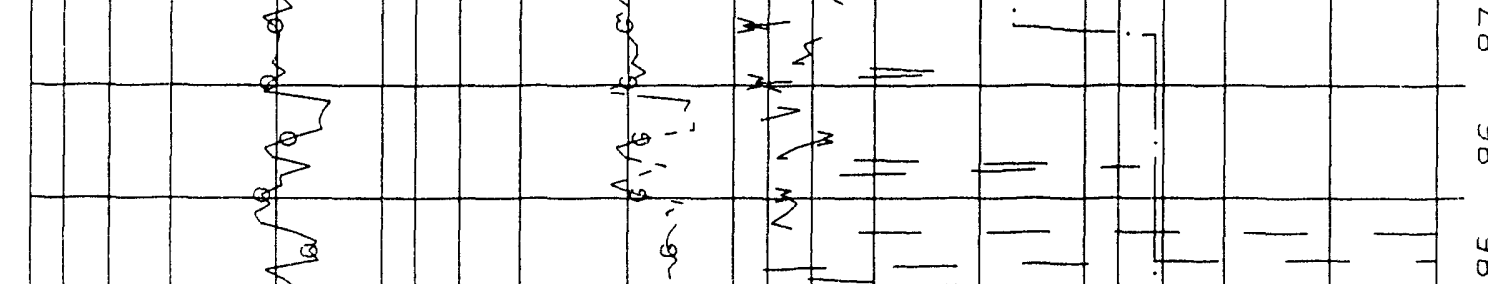

$\infty$
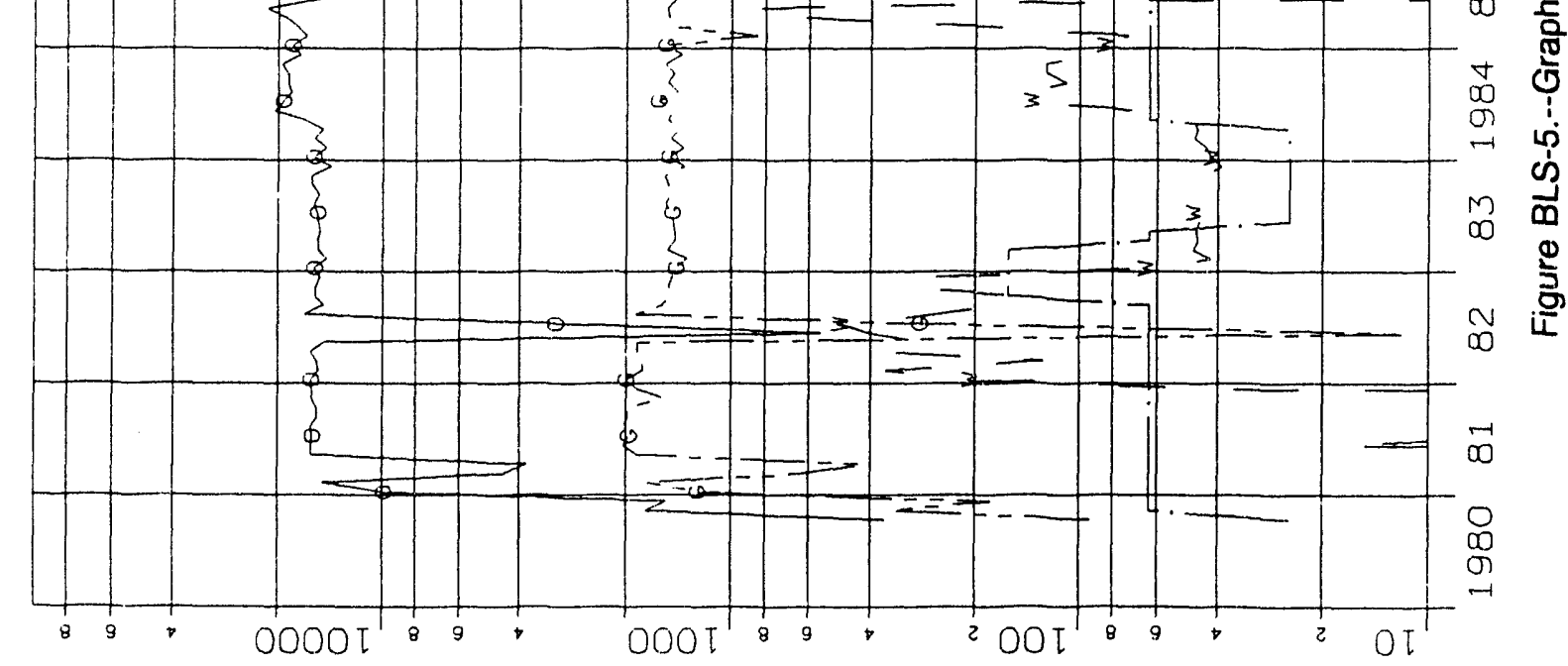

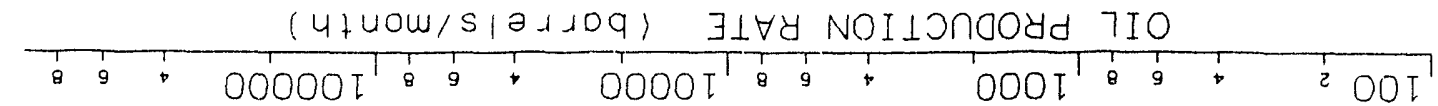

( utuow/ fOW) $\exists \perp \forall y$ NOI $\perp$ InoOyd $S \forall O$ 
(a)

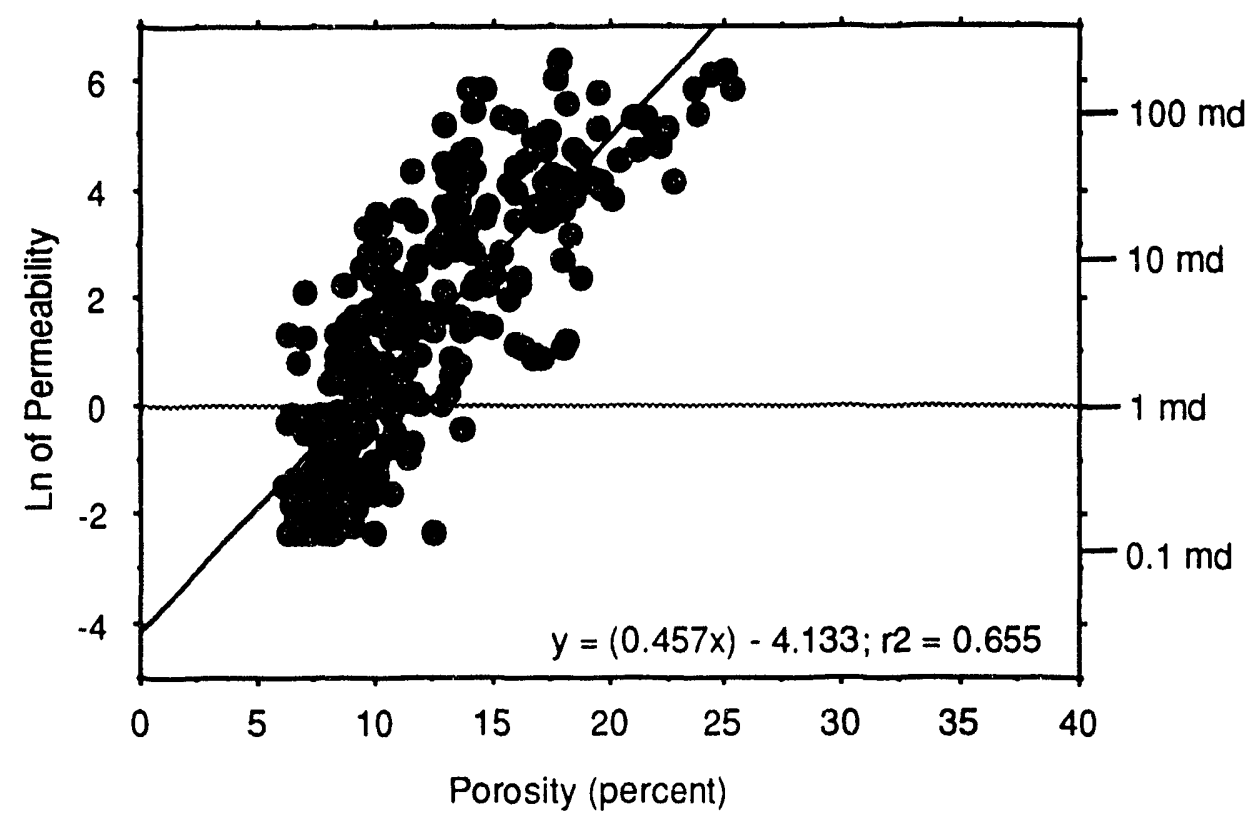

(b)

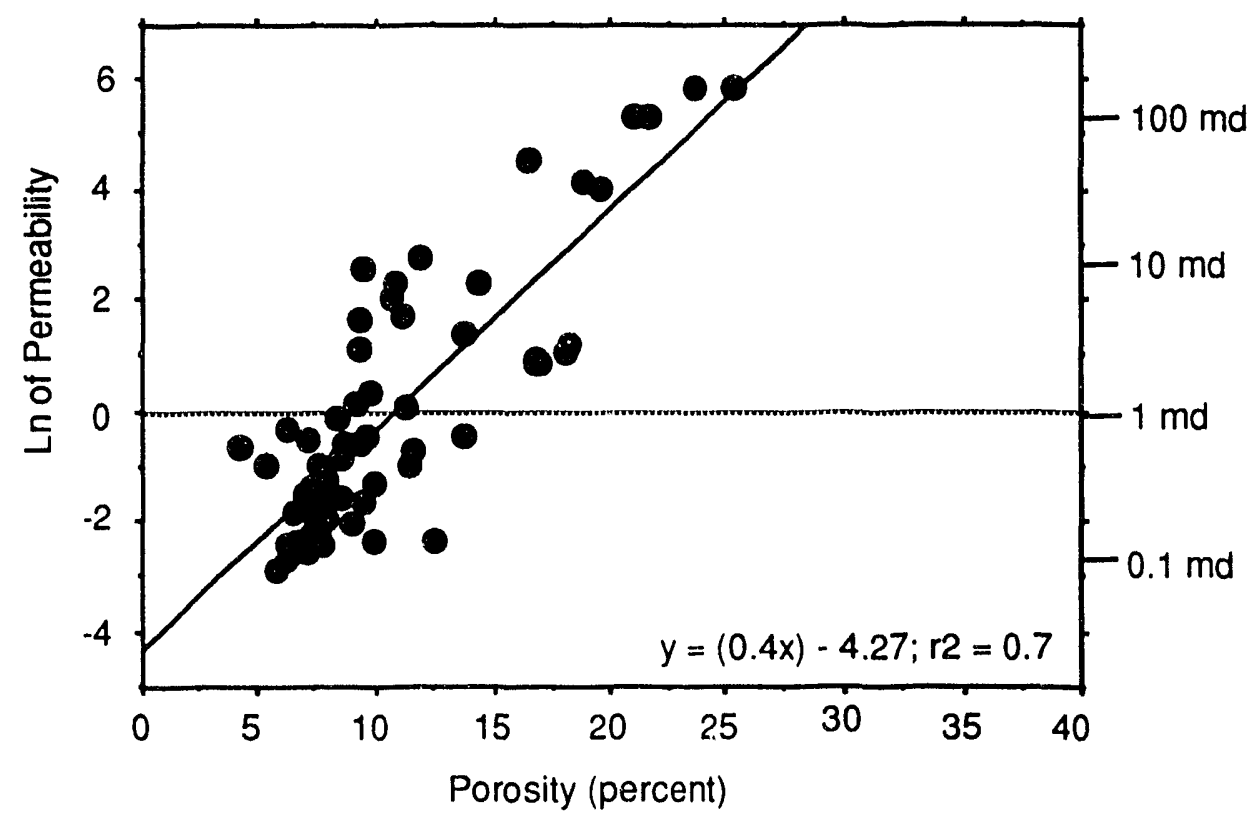

Figure BLS-6.--Porosity vs. natural log permeability plots, Blacksher figld, Alabama. (a) Plot of eight cores combined, and (b) plot of described core for International Paper Co. 20-5 No. 1 well, Permit No. 5242. Equations apply to regression lines. 
Table BLS-1.--Reservoir characterization sheet, Smackover pool, Blacksher field, Baldwin County, Alabama

\section{Discovery well}

Operator: Shell Oil Co.

Permit number: 2925

Well Name: Wefel \#2

Location: Sec. 29, T3N-R4E

Completion date: $07 / 27 / 80$

Perforations: $15,585-15,600,15,617-15,624 \mathrm{ft}$

Initial flow rate: 120 bopd, $173 \mathrm{Mcfd}$,

24/64 ck, 329 psi

Field data (as of $12 / 31 / 90$ )

Number of wells within field limits: 8

Producing wells in pool: 3

Production wells in field: 3

Shut-in/Temp. abandoned wells: 0

Plugged and abandoned wells: 4

Salt water disposal wells: 1

Enhanced recovery wells: 0

Dry holes: 0

Drilling wells: 0

Unit spacing (acres): 160

Total field area (acres): 2,400

Cumulative production

Oil (bbl): 1,897,279

Gas (Mcf): $1,879,390$

Water (bbl): 955,084

\section{Reservoir data}

Trap type: Structural / stratigraphic

Reservoir structure: Anticline

Proven productive area (acres): 1,123

Average net pay thickness (feet): 12

Hydrocarbon type: Oil

Oil gravity (API): 43

Initial reservoir pressure (psia): 8,015

Current reservoir pressure (psia): na

Reservoir drive: Solution gas / water

Type of enhanced recovery: none

Mean porosity (core) (\%): 11.60

Porosity standard deviation (\%): 4.30

Maximum porosity (\%): 25.30

Minimum porosity (\%): 6.10

Number of porosity analyses: 294

Geometric mean perm (core) (md): 3.29

Maximum permeability (md): 627.00

Minimum permeability (md): 0.10

Number of permeability analyses: 294

Dykstra-Parsons coefficient: na 


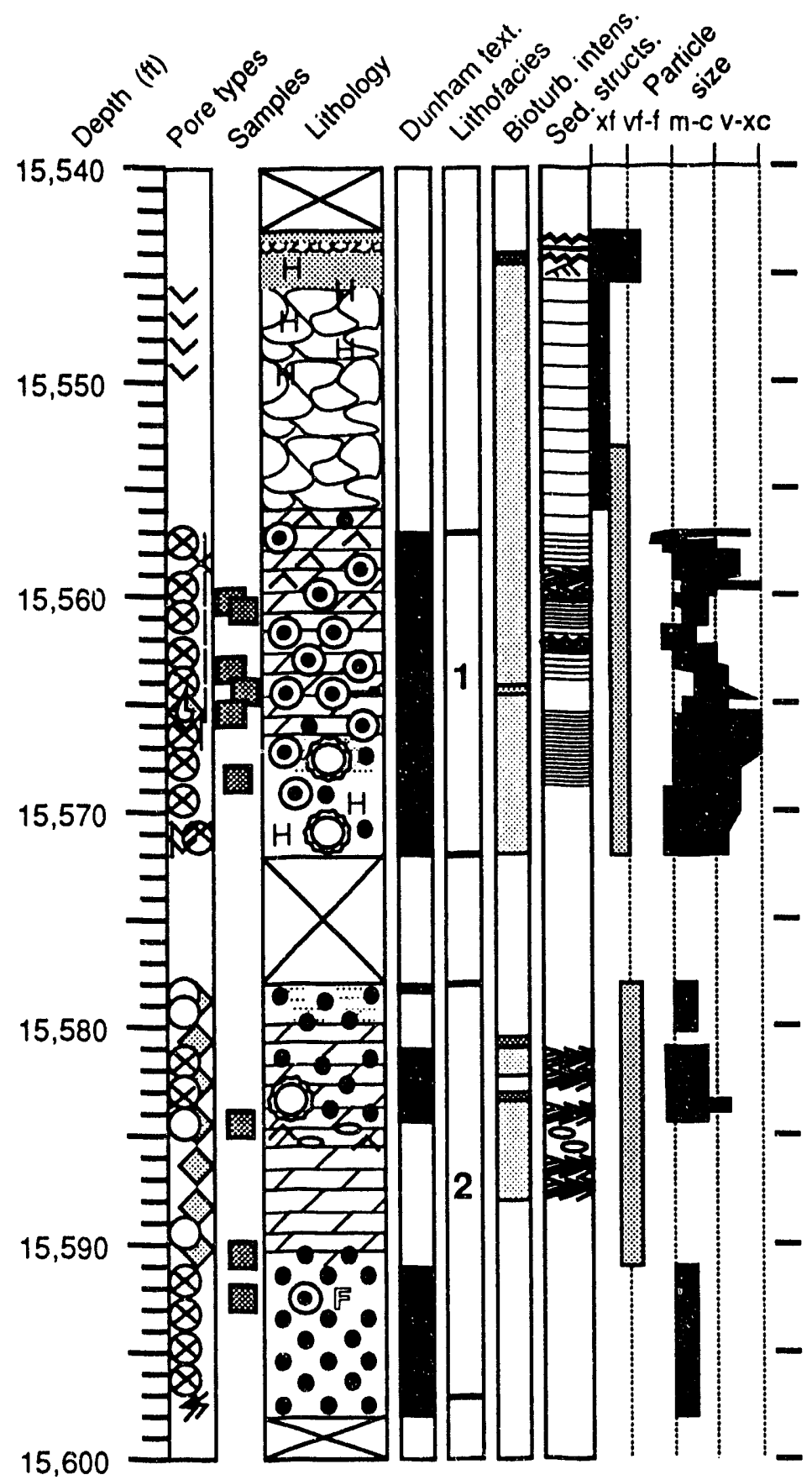

Figure BLS-7.--Detailed core log, International Paper Co. 20-5 No. 1 well, Permit No. 5242, Blacksher field, Alabama. 
Table BLS-2.--Lithofacies description of core from International Paper Co. 20-5 No. 1 well, Permit No. 5242, Blacksher field, Alabama (see figure BLS-7)

Lithofacies 1: Nonskeletal (ooid-dominated) dolograinstone and dolomitic grainstone

Pore types:

Secondary intraparticle: $49 \%$

Moldic: $29 \%$

Interparticle: $18 \%$

Vuggy: $4 \%$

Mean porosity (\%): 15.1

Maximum porosity (\%): 19.6

Minimum porosity (\%): 8.9

Porosity standard deviation (\%): 3.7

Number of analyses: 13

Geometric mean permeability (md): 5.33

Maximum permeability (md): 94.80

Minimum permeability (md): 0.14

Number of analyses: 13

Depositional Environment: High-energy beach with dune-filled runnel in upper part and soil horizon in lower part. Beach deposits overlie a shallow brine pond, and underlie thick brine-pond deposits.

Diagenesis: Early carbonate pore-lining cementation, particle dissolution, pervasive dolomitization, replacement of carbonate by anhydrite, formation of anhydrite cement.

Percent of reservoir: 44

Depth interval(s) (ft): $15,557-15,572$

Lithofacies 2: Peloid dolograinstone and peloid grainstone; crystalline dolostone; oncoidal fenestral peloid grainstone.

Pore types:

Intercrystalline: $51 \%$

Moldic: $25 \%$

Secondary intraparticle: $15 \%$

Fracture: $8 \%$

Mean porosity (\%): 15.0

Maximum porosity (\%): 25.3

Minimum porosity (\%): 6.2

Porosity standard deviation (\%): 7.0

Number of analyses: 10 
Table BLS-2.--Lithofacies description of core from International Paper Co. 20-5 No. 1 well, Permit No. 5242, Blacksher field, Alabama (see figure BLS-7) -- Continued

Geometric mean permeability (md): 25.14

Maximum permeability (md): 353.00

Minimum permeability (md): 0.77

Number of analyses: 10

Depositional Environment: Barrier complex with both subtidal (cross-laminated) and supratidal (fenestral) elements. On top of this barrier developed the brine pond overlain by the beach deposits of lithofacies 1 .

Diagenesis: Pervasive dolomitization of upper part. Anhydrite is abundant as replacive laths and nodules, displacive nodules, and as pore-filling cement. Anhydrite formation was followed by minor dolomitization of anhydrite.

Percent of reservoir: 56

Depth interval(s) (ft): $15,578-15,597$ 
(a)

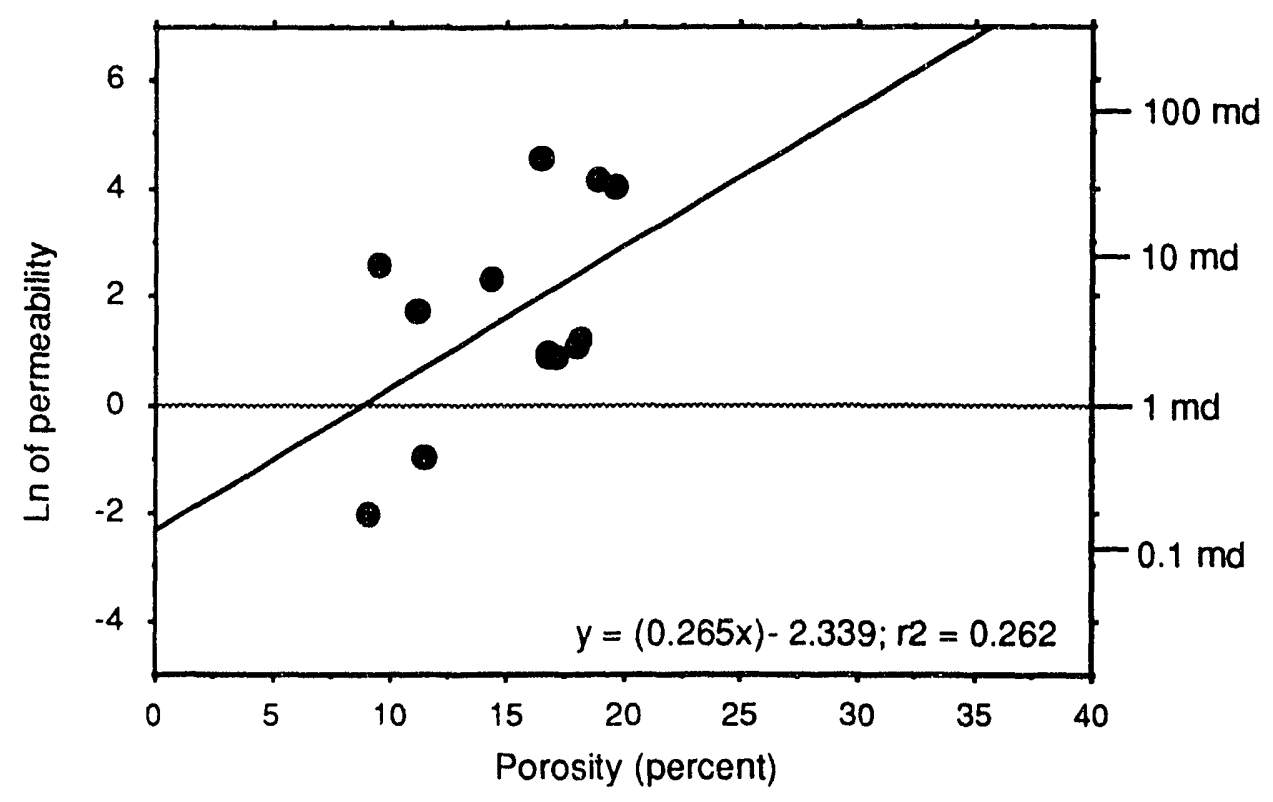

(b)

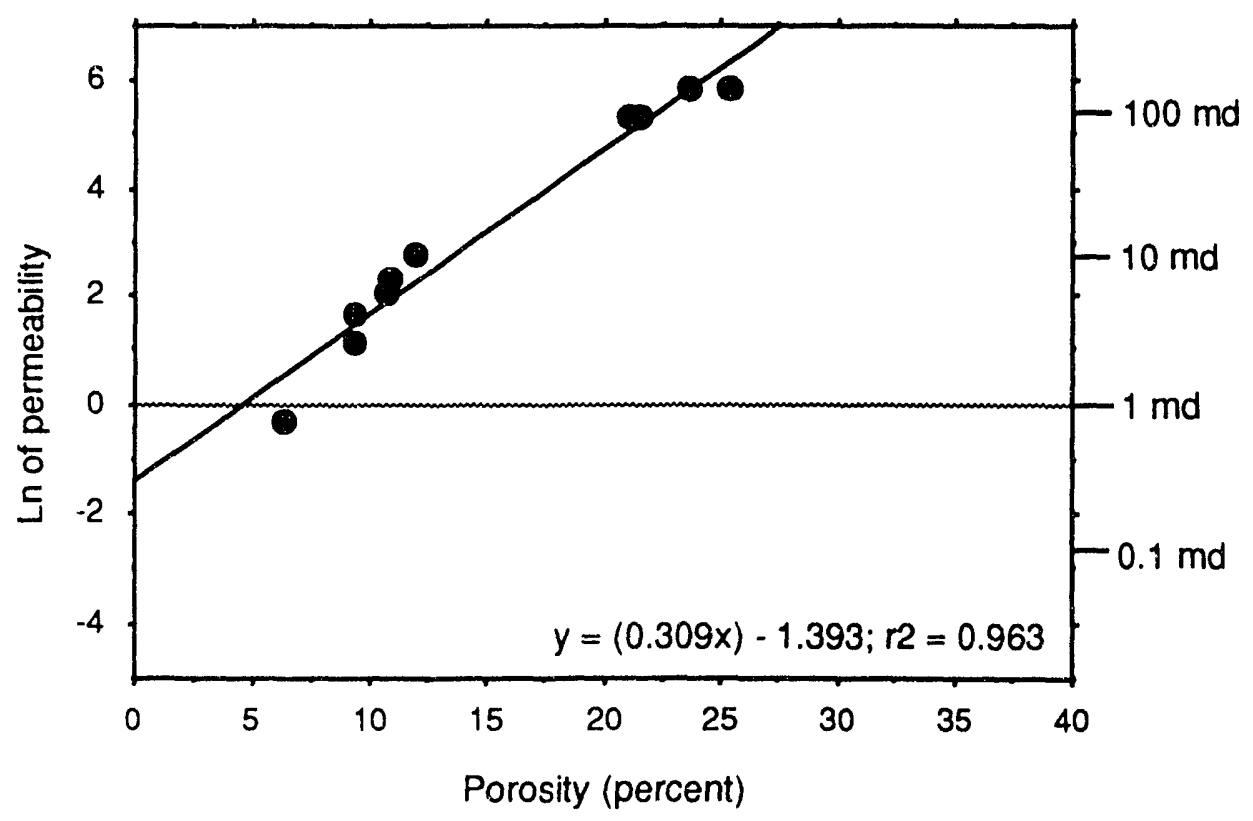

Figure BLS-8.--Porosity vs. natural log permeability plots for lithofacies, International Paper Co. 20-5 No. 1 well, Permit No. 5242, Blacksher field, Alabama. (a) Lithofacies 1 and (b) lithofacies 2. Equations for regression lines are printed for each lithofacies. (See table BLS-2 for descriptions of lithofacies.) Data set excludes all samples with porosity values and permeability values below reservoir cutoffs at $6 \%$ and $01.1 \mathrm{md}$, respectively. 


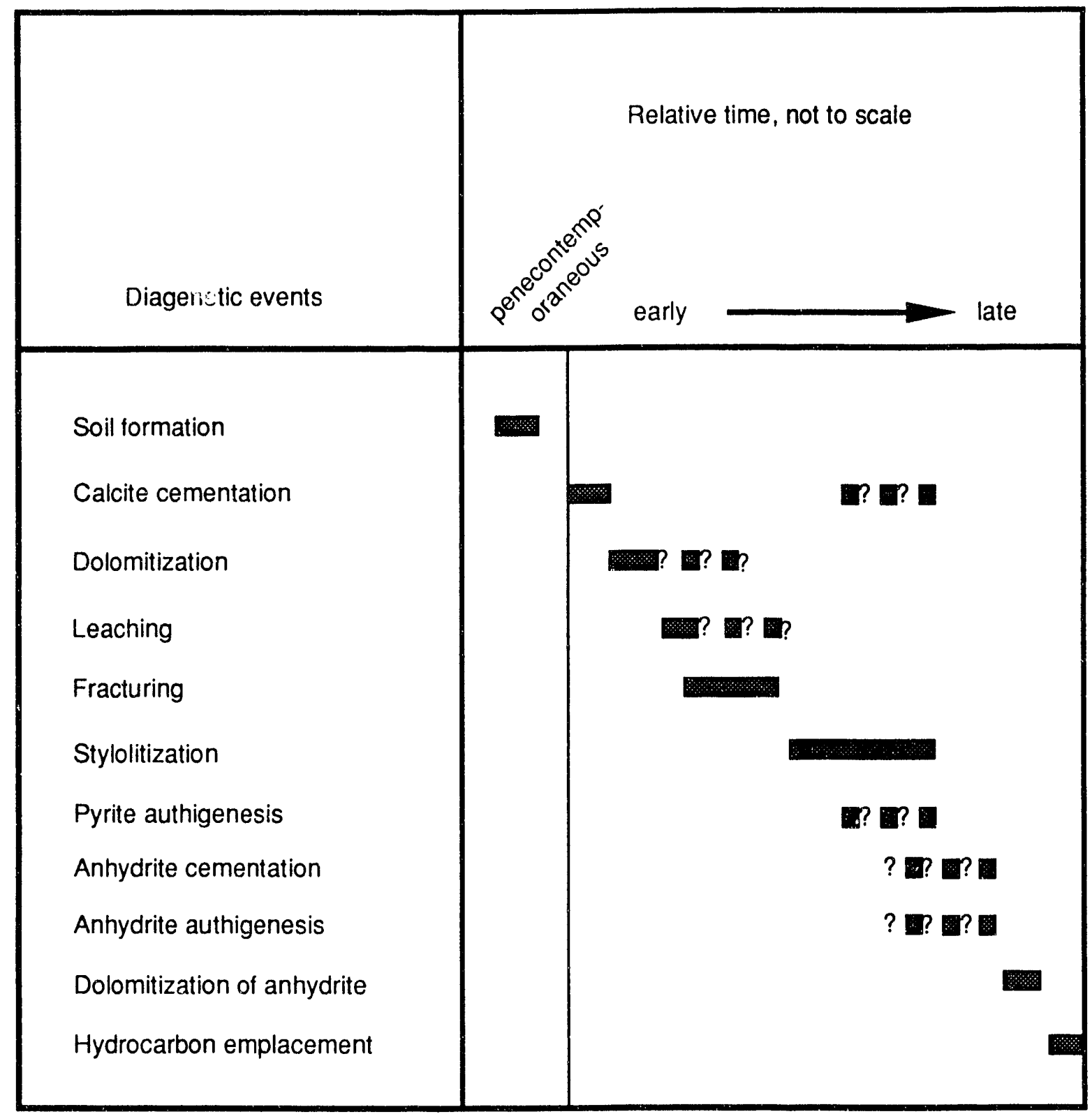

Figure BLS-9.--Paragenetic sequence, International Paper Co. 20-5 No. 1 well, Permit No. 5242, Blacksher field, Alabama. 


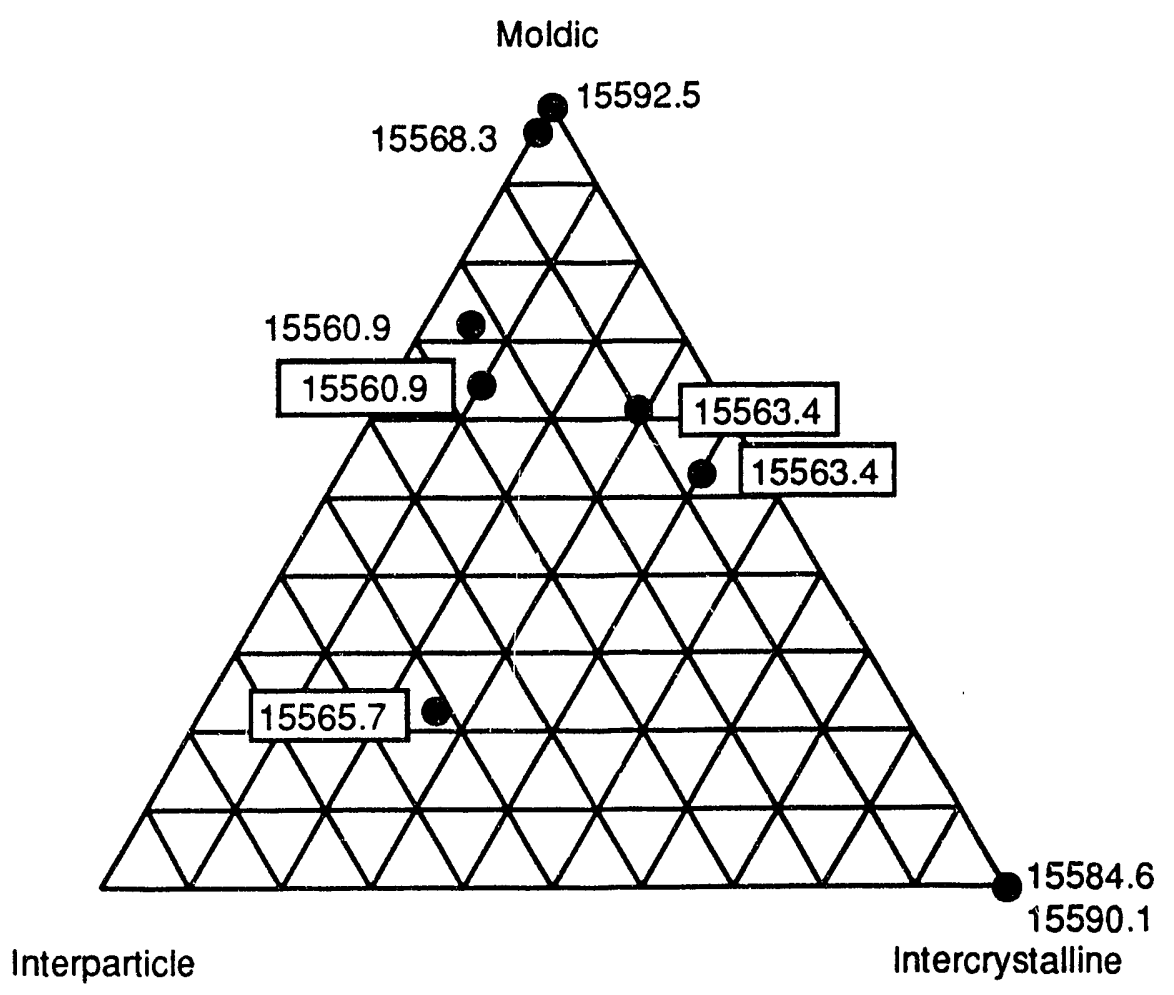

Figure BLS-10.--Ternary diagram of pore types, International Paper Co. 20-5 No. 1 well, Permit No. 5242, Blacksher field, Alabama. Percentages of moldic pores indicated. Sample depths are indicated to nearest 0.1 foot. 


\section{BROKEN LEG CREEK FIELD}

\section{SMACKOVER OIL POOL}

ESCAMBIA COUNTY, ALABAMA 
73

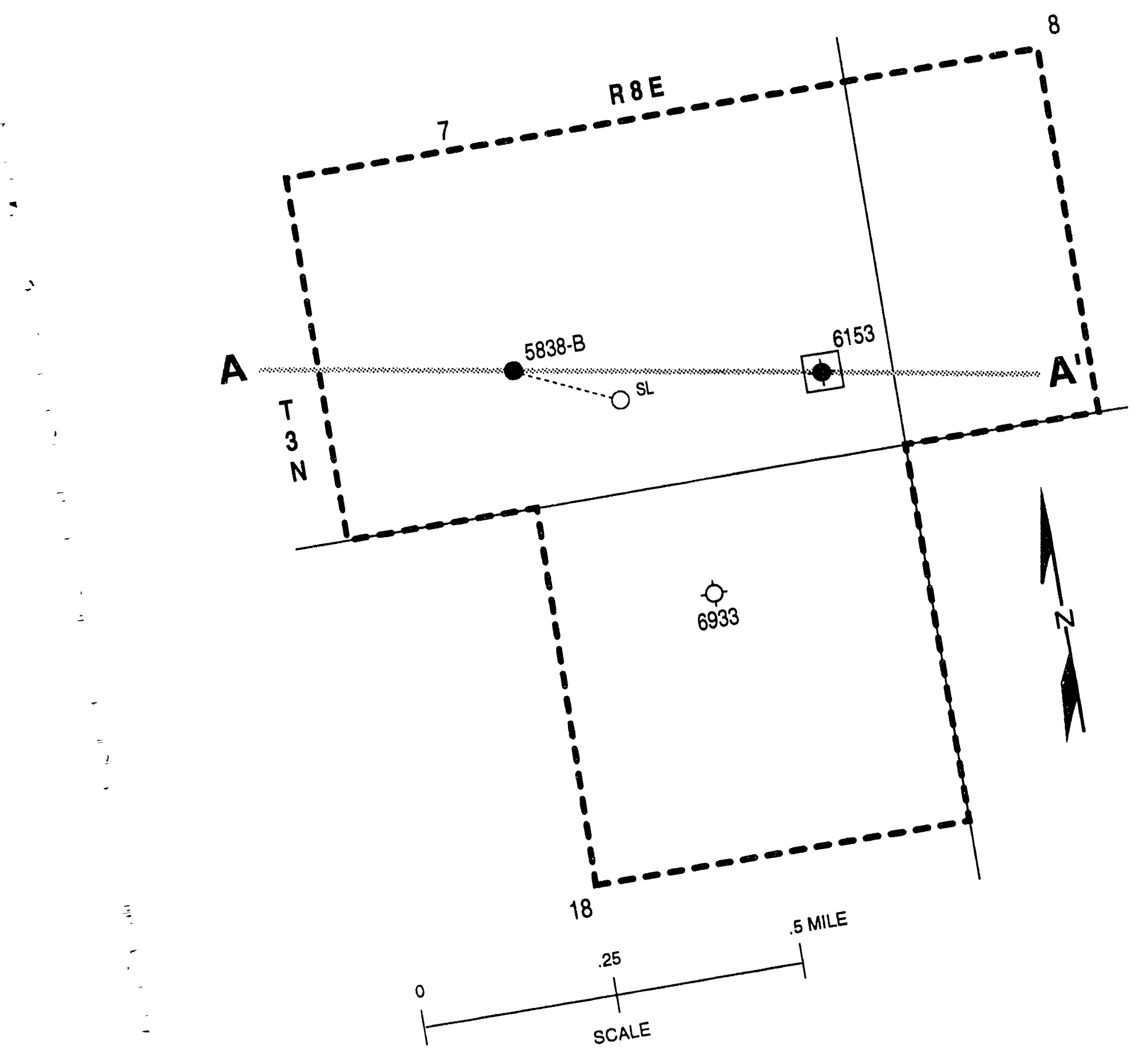

Figure BLC-1.--Index map of Broken Leg Creek field, Alabama 


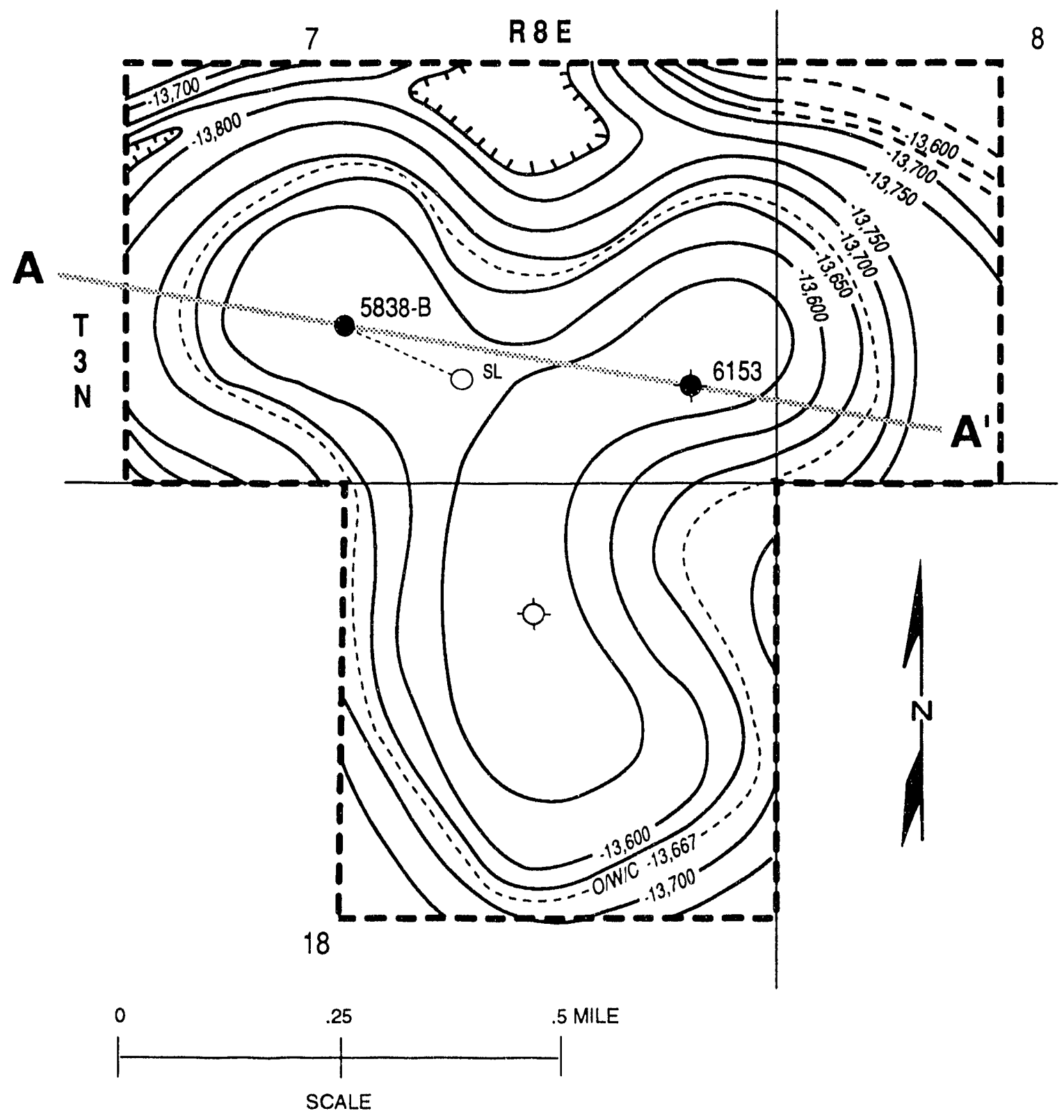

Figure BLC-2.--Structure contour map on top of Smackover Formation in Broken Leg Creek field, Alabama. 


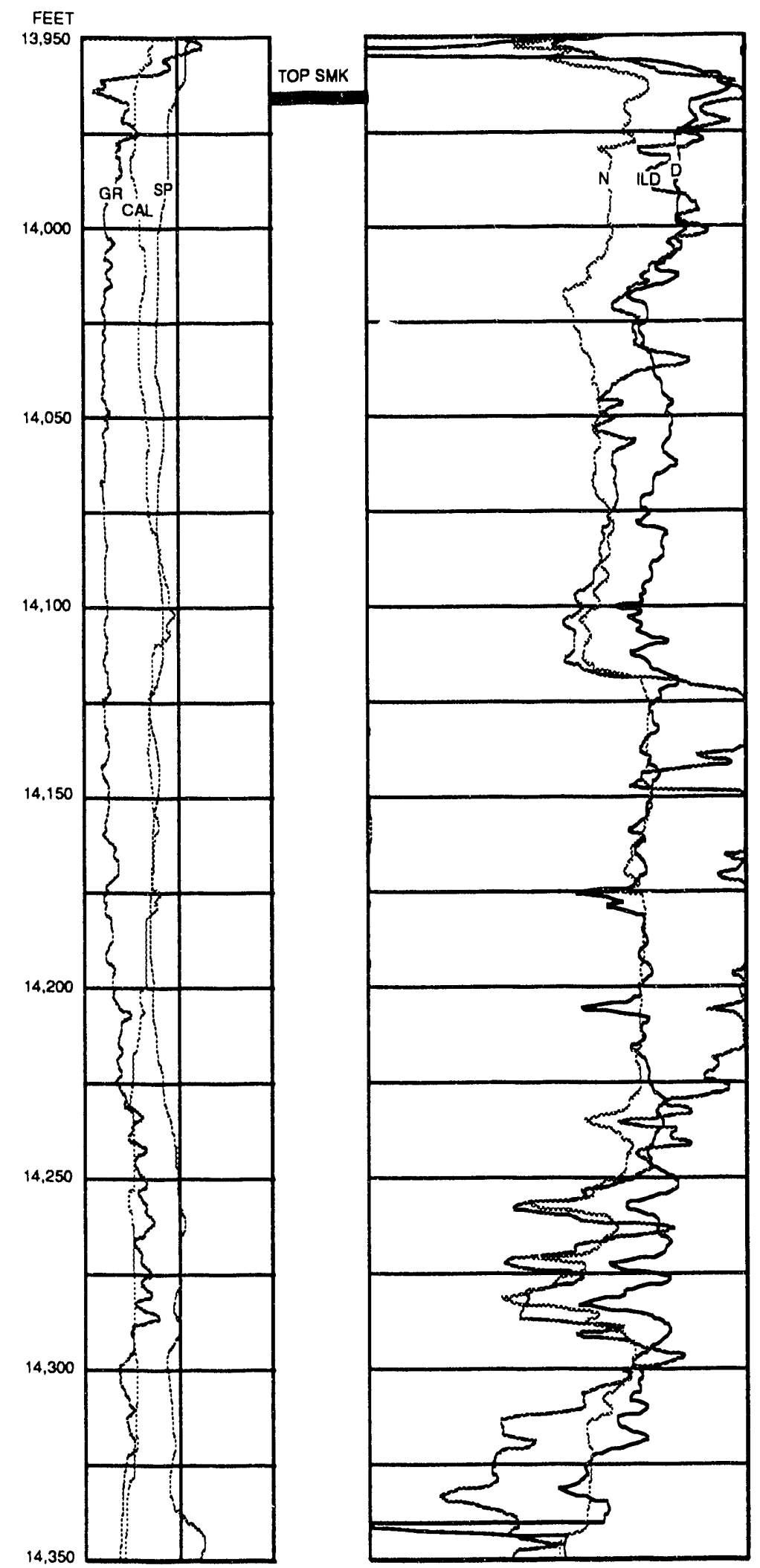

Figure BLC-3.--Well log, Hawkins 7-16 No. 1 well, Permit No. 6153-B, Broken Leg Creek field, Alabama. 


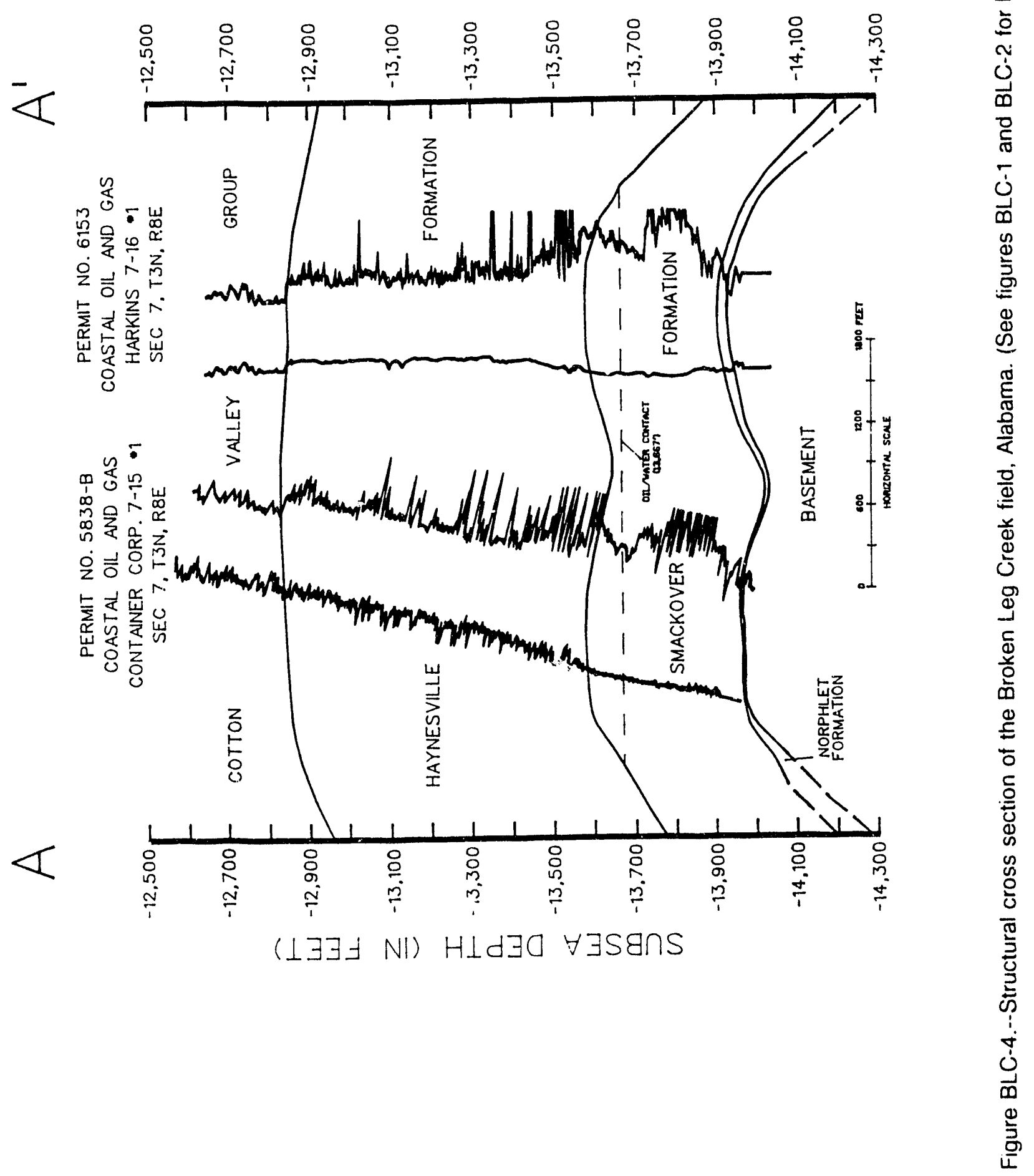



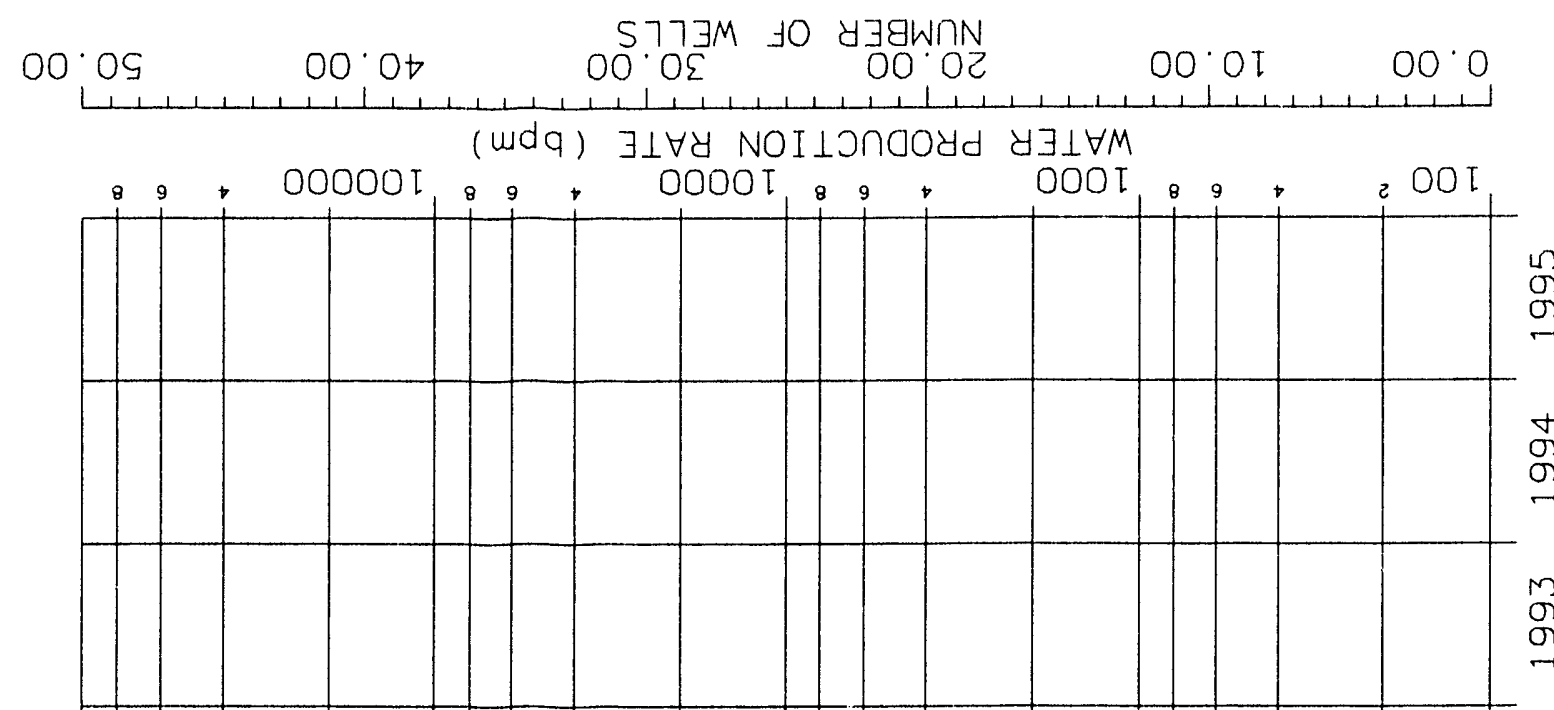

$\underset{\substack{\text { O } \\ \sim}}{\sim}$

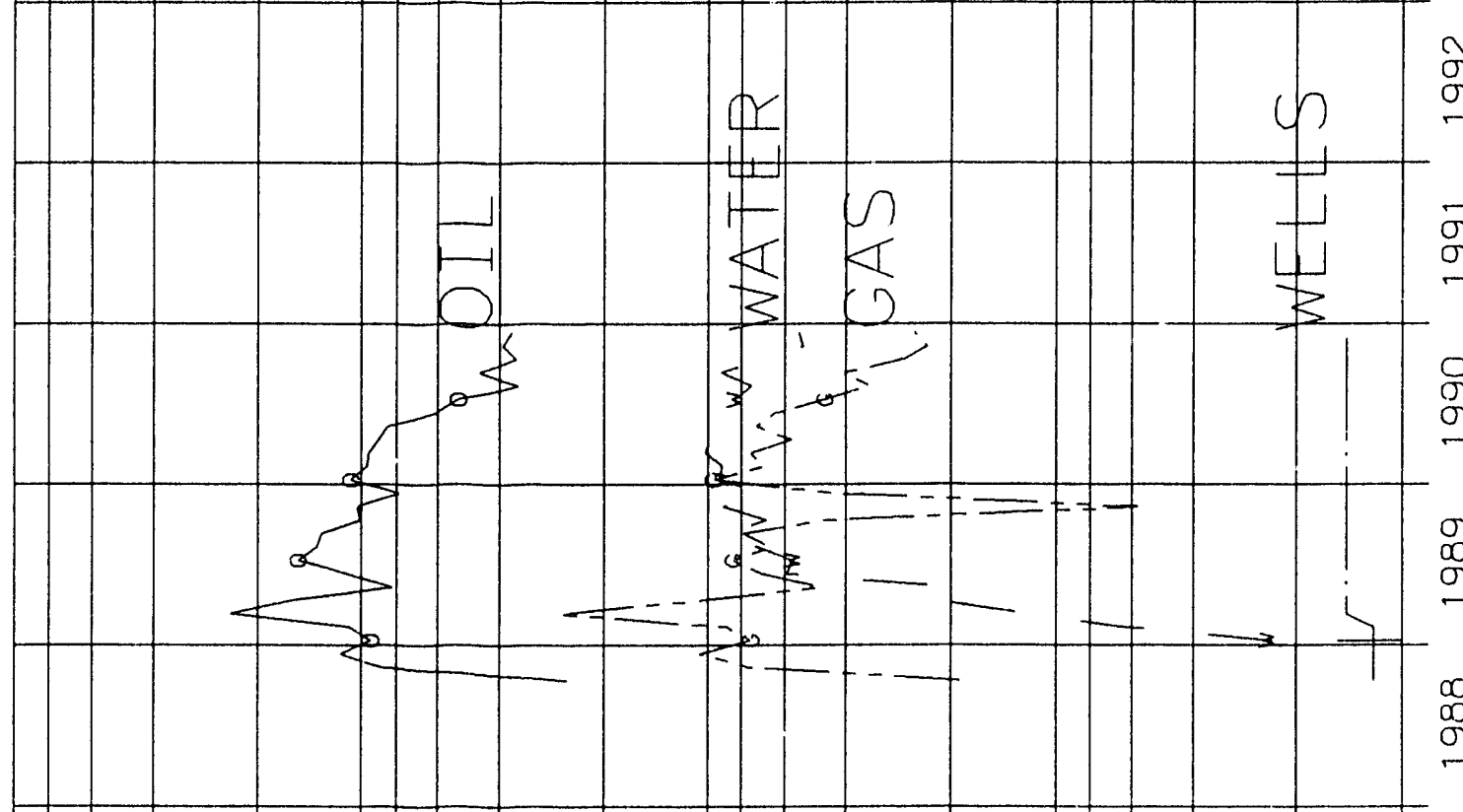

$\begin{array}{ll}\sim & \\ \sigma & 0 \\ \sigma & 0\end{array}$

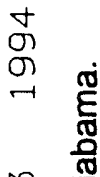

M $\frac{1}{\alpha}$

$\rightarrow$

$\stackrel{0}{\underline{0}}$

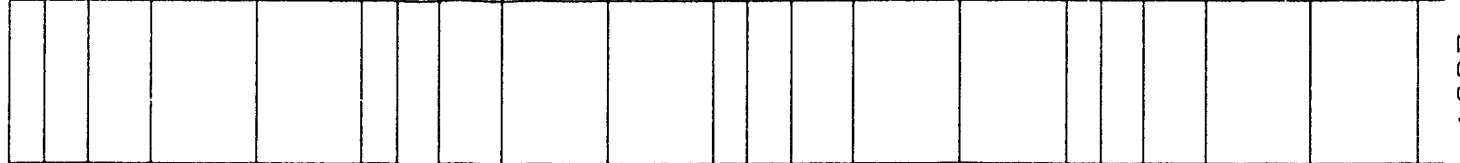

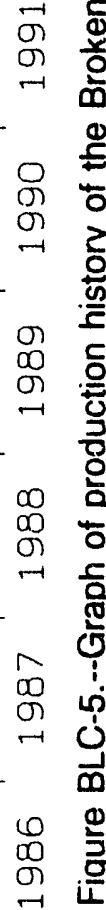

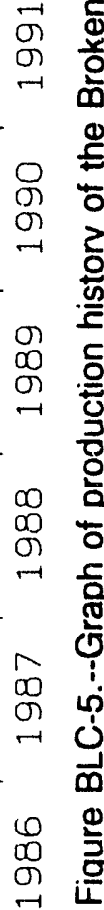

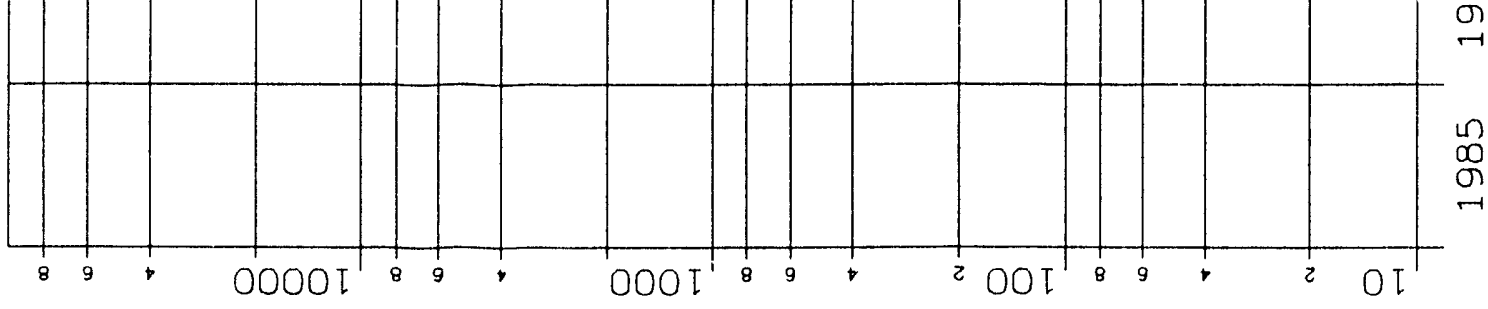

$\underset{\substack{n \\ \infty}}{\infty}$

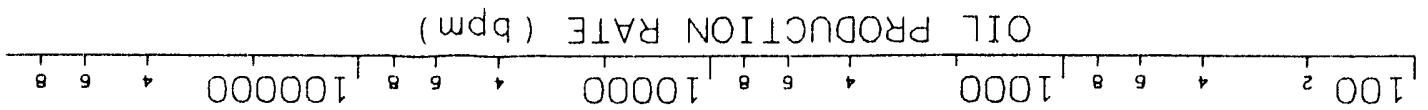

( 4 tuOW/fOSW) $\exists \perp \forall Y$ NOI IOnOOYd $5 \forall 0$ 


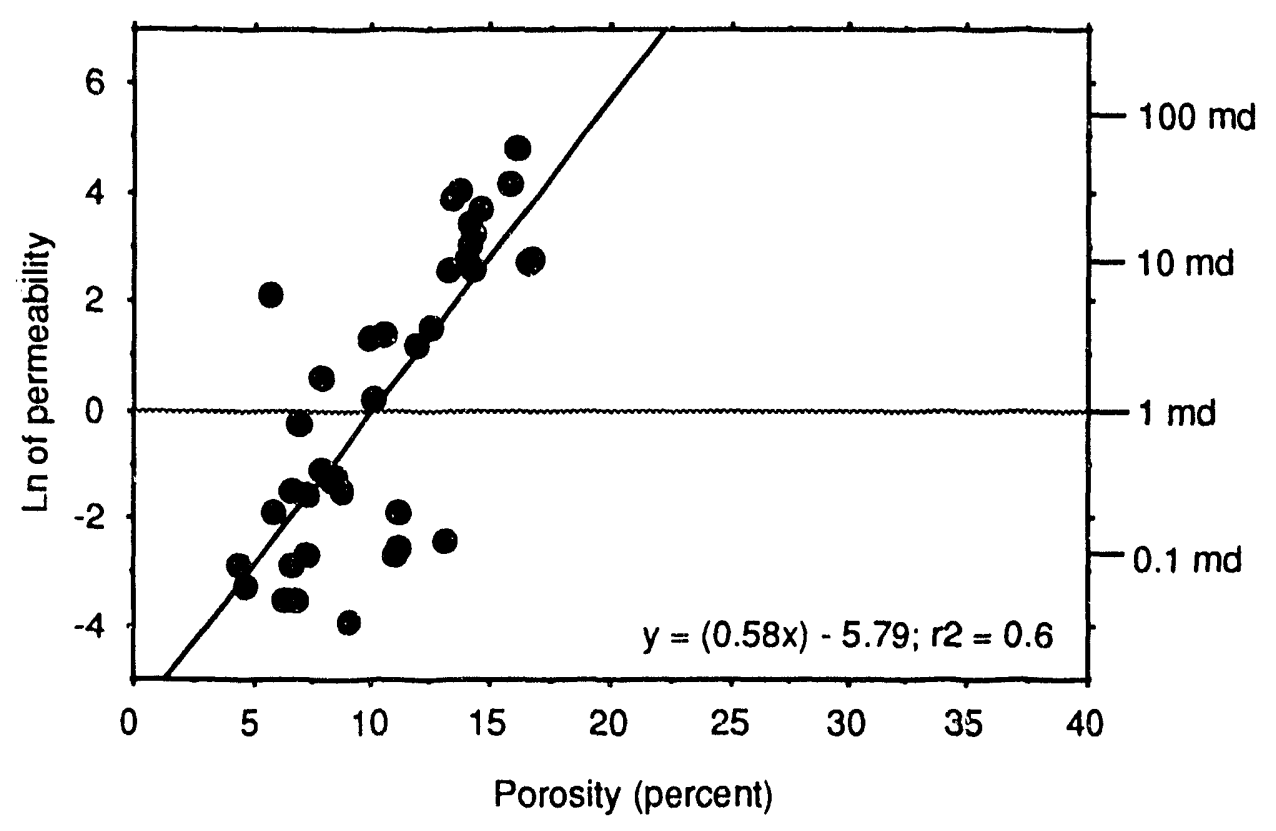

Figure BLC-6.--Porosity vs. natural log permeability plot of one core, Broken Leg Creek field, Alabama. Equation applies to regression line. 
Table BLC-1.--Reservoir characterization sheet, Smackover pool, Broken Leg Creek field, Escambia County, Alabama

\section{Discovery well}

Operator: Coastal Oil \& Gas Corp.

Permit number: 5838-B

Well Name: Container Corp. 7-15 \#1

Location: Sec. 7, T3N-R8E

Completion date: 10/07/88

Perforations: $14,067-14,108 \mathrm{ft}$

Initial flow rate: 792 bopd, 779 Mcfd,

14/64 ck, 2,440 psi

\section{Fleld data (as of $12 / 31 / 90$ )}

Number of wells within field limits: 3

Producing wells in pool: 2

Production wells in field: 2

Shut-in/Temp. abandoned wells: 0

Plugged and abandoned wells: 1

Salt water disposal weils: 0

Enhanced recovery wells: 0

Dry holes: 0

Drilling wells: 0

Unit spacing (acres): 160

Total field area (acres): 480

Cumulative production

Oil (bbl): 249,838

Gas (MCf): 180,916

Water (bbl): 155,512

\section{Reservoir data}

Trap type: Structural

Reservoir structure: Anticline

Proven productive area (acres): 263

Average net pay thickness (feet): 26

Hydrocarbon type: Oil

Oil gravity (API): 41

Initial resenvoir pressure (psia): 6,725

Current reservoir pressure (psia): $\sim 5,000$

Resenoir drive: Solution gas / water

Type of enhanced recovery: none

Mean porosity (core) (\%): 9.53

Porosity standard deviation (\%): 3.91

Maximum porosity (\%): 16.50

Minimum porosity (\%): 2.60

Number of porosity analyses: 47

Geometric mean perm (core) (md): 1.32

Maximum permeability (md): 0.02

Minimum permeability (md): 0.02

Number of permeability analyses: 39

Dykstra-Parsons coefficient: na 


\section{BUCATUNNA CREEK FIELD}

SMACKOVER OIL POOL

CHOCTAW COUNTY, ALABAMA 


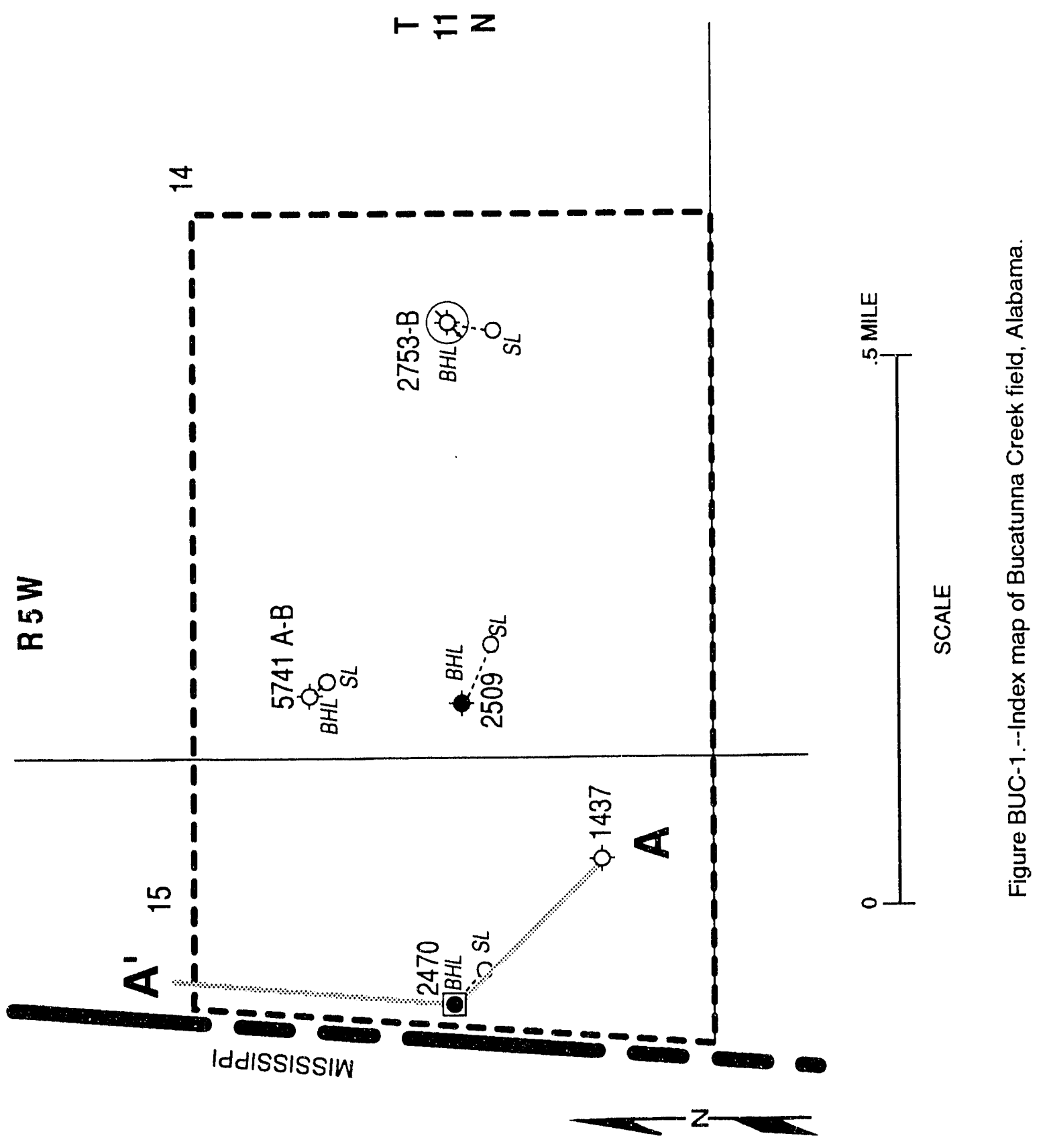




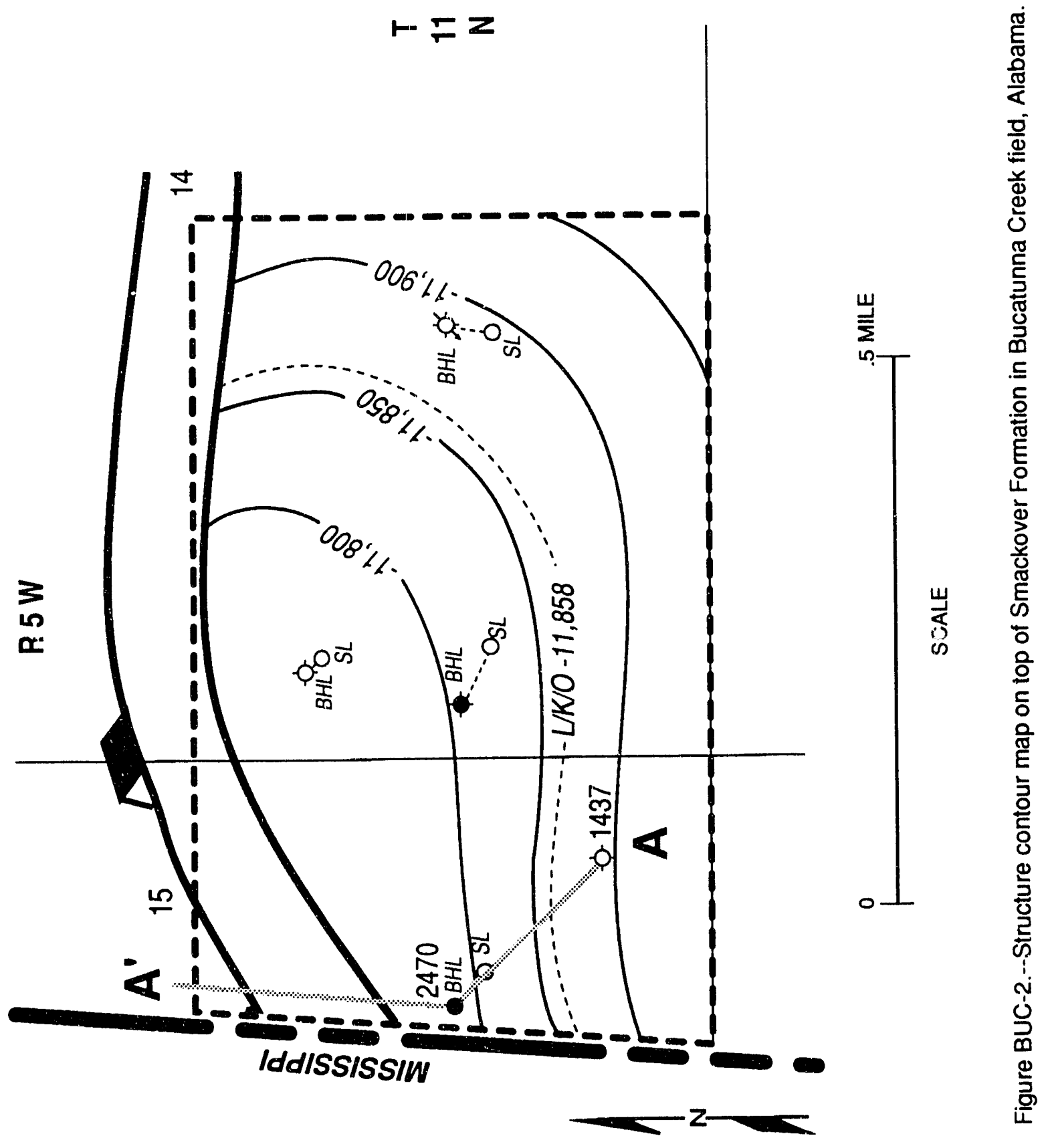




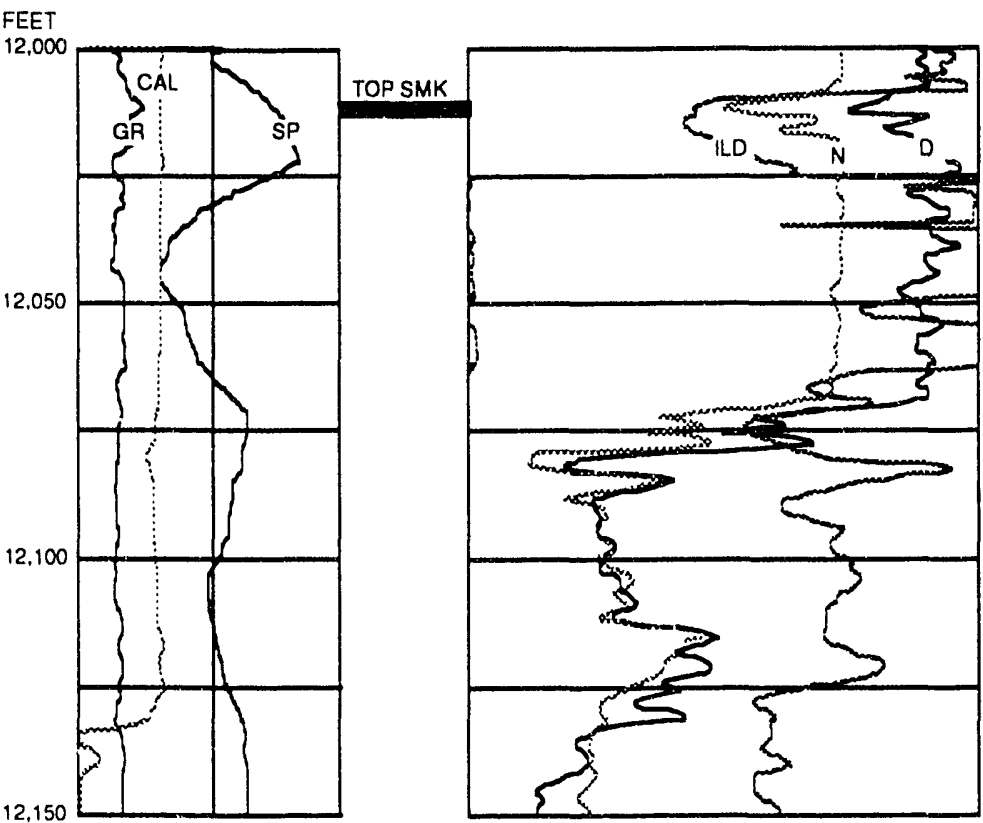

Figure BUC-3.--Well log, A. G. Harrell No. 1 well, Permit No. 2470, Bucatunna Creek field, Alabama. 
\&
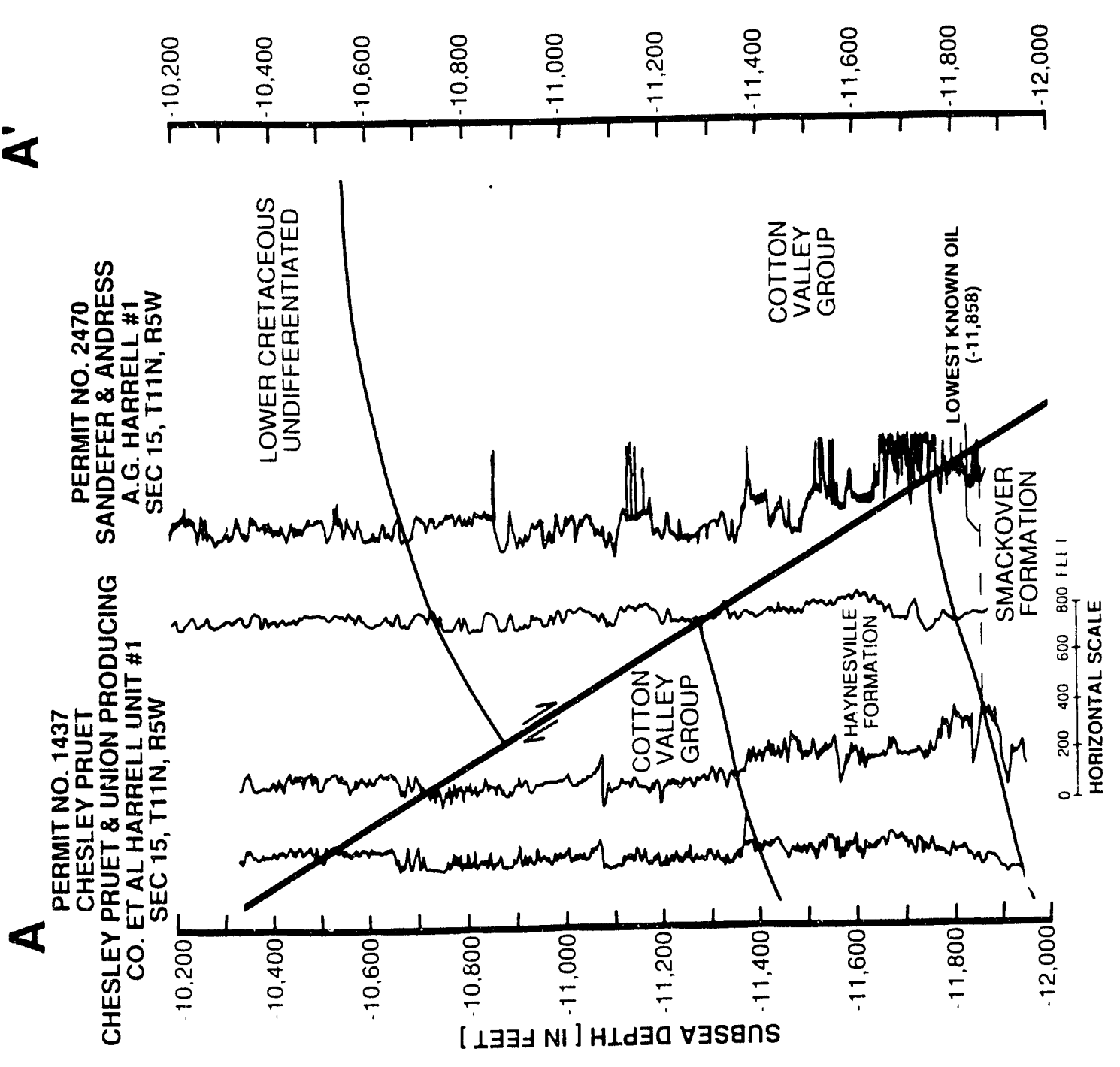


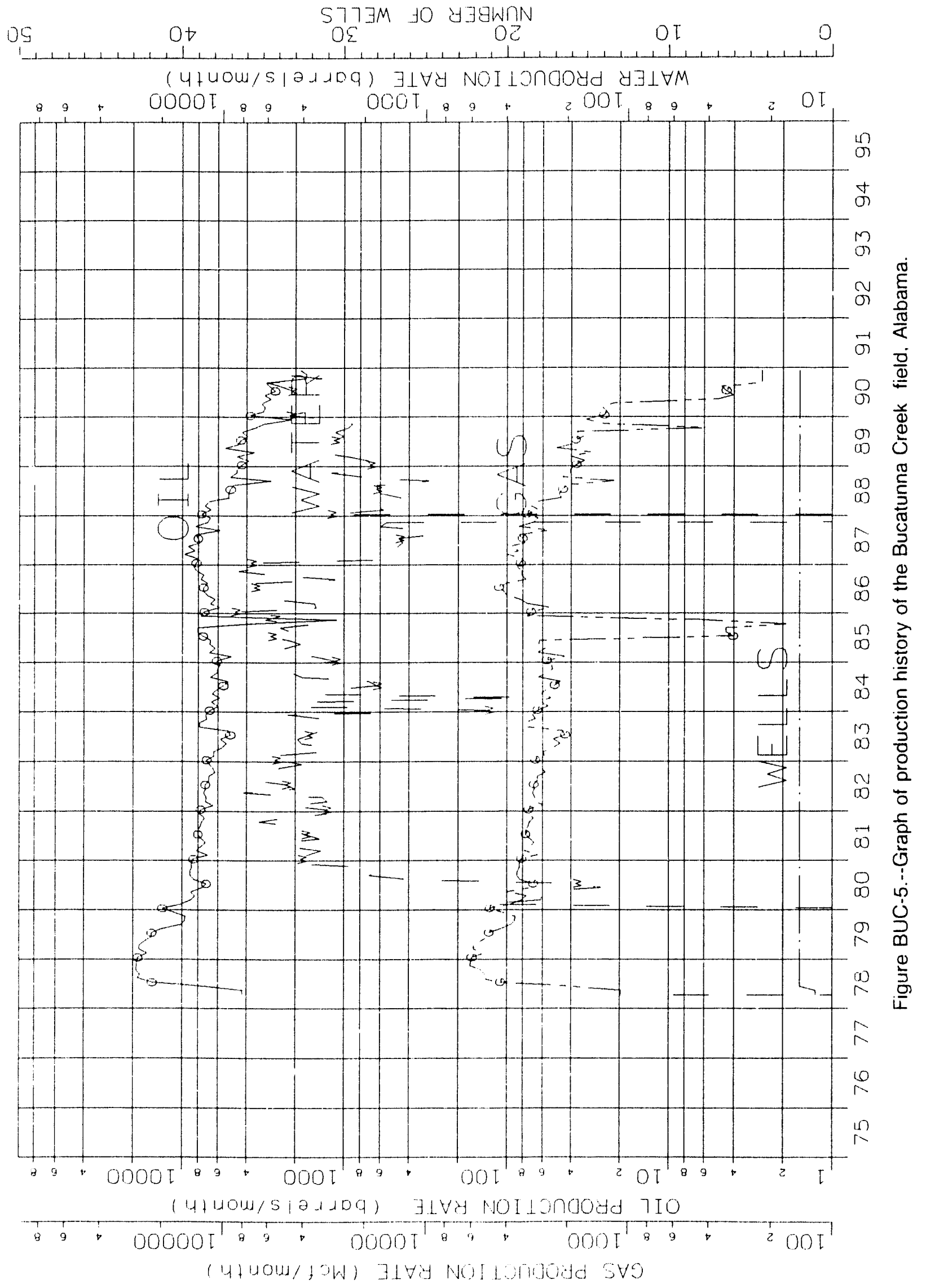


(a)

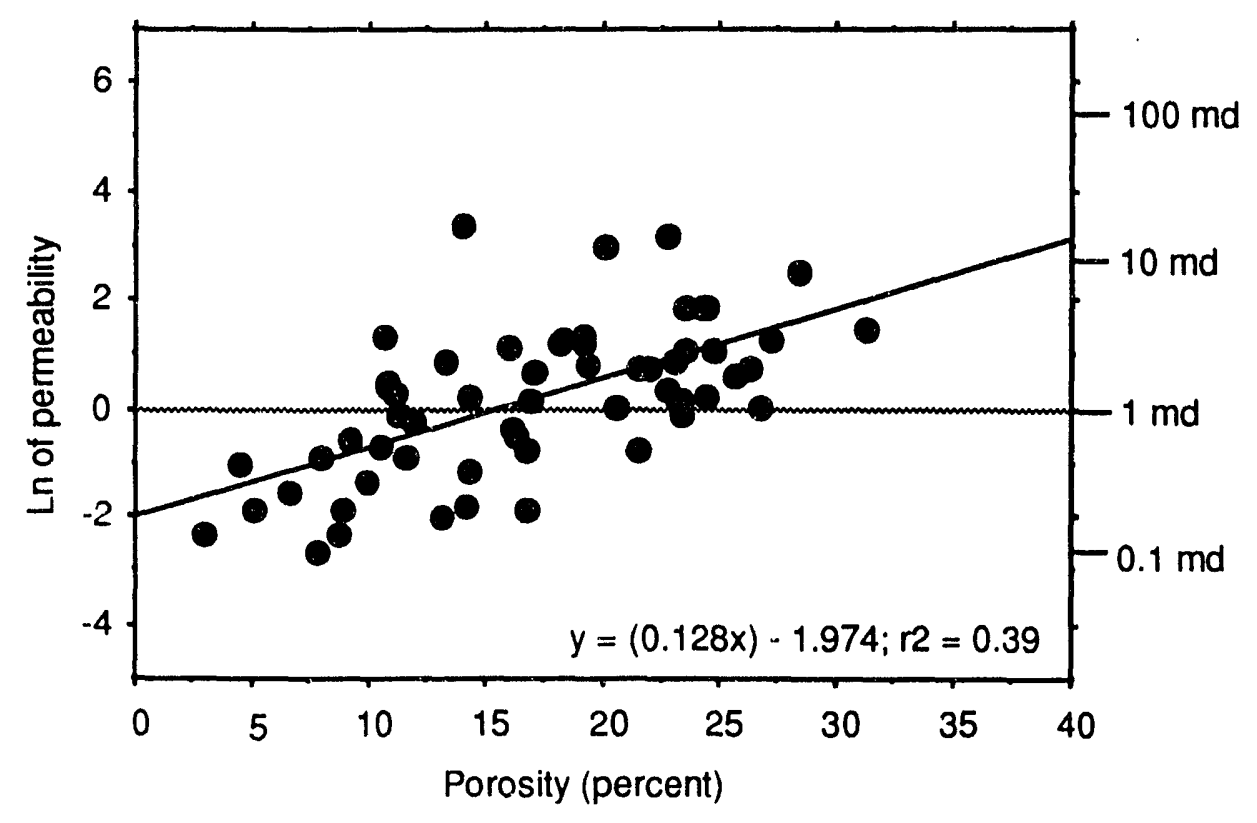

(b)

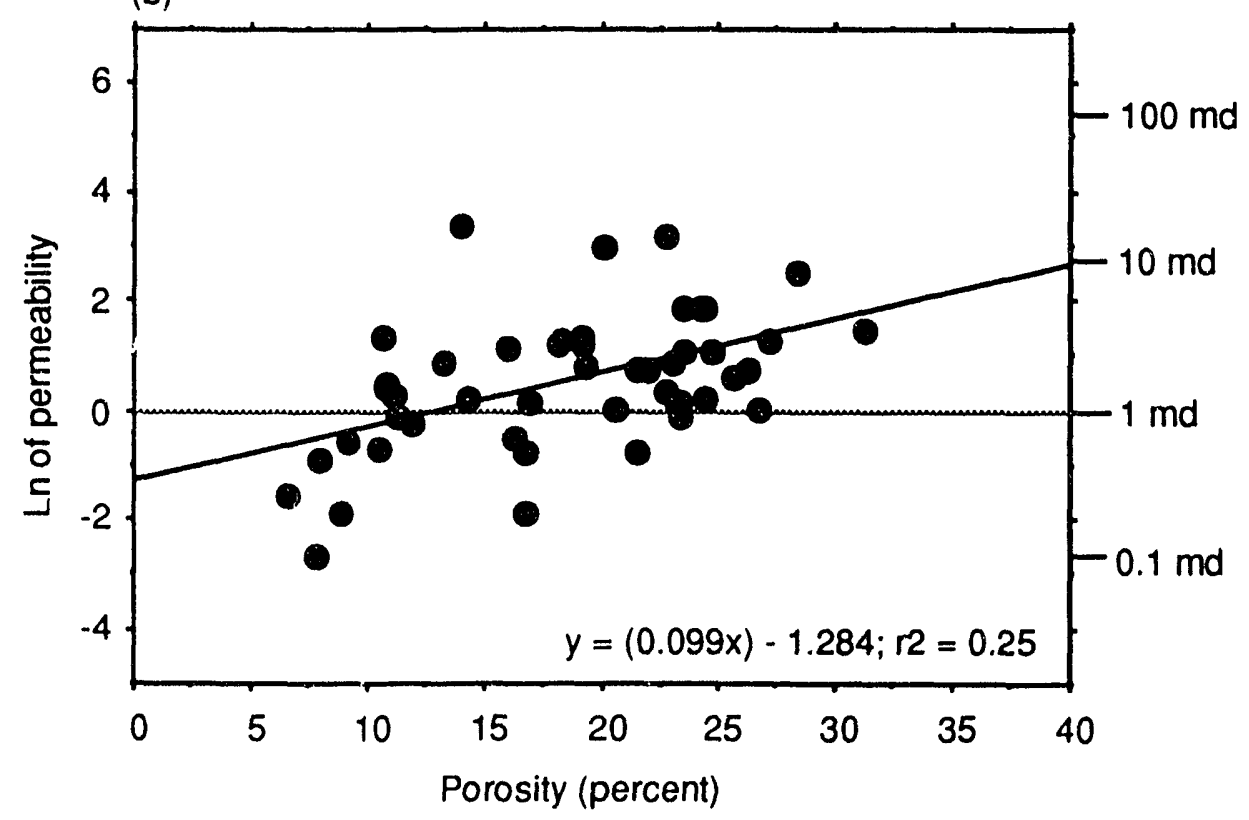

Figure BUC-6.--Porosity vs. natural log permeability plots, Bucatunna Creek field, Alabama. (a) Plot of two cores combined, and (b) plot of described core for Johnson Unit 14-14 No. 1 well, Permit No. 2753-B. Equations apply to regression lines. 
Table BUC-1.--Reservoir characterization sheet, Smackover pool, Bucatunna Creek field, Choctaw County, Alabama

\section{Discovery well}

Operator: Sandefer \& Andress, Inc.

Permit number: 2470

Vvell Name: A. G. Harrel \#1

Location: Sec. 15, T11N-R5W

Completion date: $3 / 31 / 78$

Perforations: $12,071-12,100 \mathrm{ft}$

Initial flow rate: 338 bopd, 99 Mcfd,

12/64 ck, 775 psi

Field data (as of 12/31/90)

Number of wells within field limits: 6

Producing wells in pool: 1

Production wells in field: 1

Shut-in/Temp. abandoned wells: 0

Plugged and abandoned wells: 2

Salt water disposal wells: 1

Enhanced recovery wells: 0

Dry holes: 2

Drilling wells: 0

Unit spacing (acres): 80

Total field area (acres): -240

Cumulative production

Condensate (bbl): $1,134,435$

Gas (Mcf): 425,410

Water (bbl): 461,027

\section{Reservoir data}

Trap type: Structural

Reservoir structure: Faulted anticline

Proven productive area (acres): 126

Average net pay thickness (feet): 45

Hydrocarbon type: Oil

Oil gravity (API): 36.6

Initial reservoir pressure (psia): 5,596

Current reservoir pressure (psia): 3,285

Reservoir drive: Solution gas / water

Type of enhanced recovery: none

Mean porosity (core) (\%): 17.00

Porosity standard deviation (\%): 6.80

Maximum porosity (\%): 31.20

Minimum porosity (\%): 2.90

Number of porosity analyses: 59

Geometric mean perm (core) (md): 1.23

Maximum permeability (md): 30.60

Minimum permeability (md): 0.07

Number of permeability analyses: 59

Dykstra-Parsons coefficient: na 


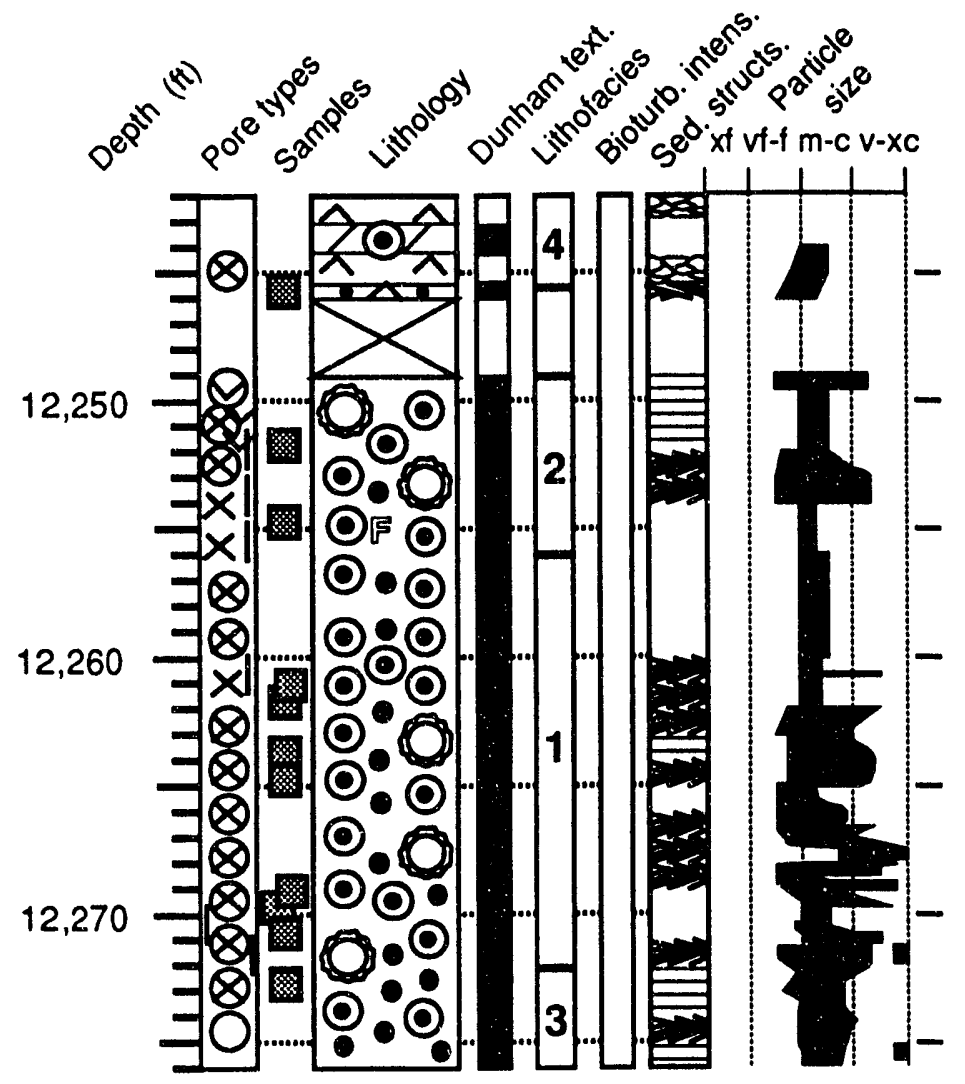

Figure BUC-7.--Detailed core log, Johnson Unit 14-14 No. 1 well, Permit No. 2753, Bucatunna Creek field. Alabama. 
Table BUC-2.--Lithofacies description of core from Johnson Unit 14-14 No. 1 well, Permit No. 2753, Bucatunna Creek field, Alabama (see figure BUC-7)

Lithofacies 1: Oncoidal, pelletal, and oolitic grainstone

Pore types:

Secondary intraparticle: $52 \%$ (iicluding all 3 particle types: oncoids, pellets, ooids)

Particle moldic: $48 \%$ (all 3 particle types)

Vuggy: trace

Mean porosity (\%): 19.2

Maximum porosity (\%): 24.3

Minimum porosity (\%): 10.6

Porosity standard deviation (\%): 3.8

Number of analyses: 25

Geometric mean permeability $(\mathrm{md}): 2.39$

Maximum permeability (md): 30.60

Minimum permeability (md): 0.16

Number of analyses: 25

Depositional Environment: Flood-tidal delta, periodically inactive, with resultant growth of abundant oncoids.

Diagenesis: The core is brown in color and was interpreted as dolostone in the coreanalysis report. Actually, dolomite composes $<10$ percent of this lithofacies. Early marine rim cement forms a rigid framework in much of this lithofacies, but interparticle interpenetration and porosity occlusion by overcompaction are important locally, and in the uppermost 4 feet of this lithofacies. Late pressure solution formed stylolites and associated replacive anhydrite, including a $2-\mathrm{cm}$ stylocumulate, without substantial porosity reduction. Leaching of unstable particles generated the pore system during or after the major episode of compaction.

Percent of reservoir: 52

Depth interval(s) (ft): 12,256-12,272

Lithofacies 2: Ooid grainstone

Pore types:

Secondary intraparticle: $45 \%$

Interparticle: $40 \%$

Moldic: $5 \%$

Solution-modified: $5 \%$

Vuggy: $5 \%$

Intercrystalline: trace

Fracture: trace

Mean porosity: 10.1 
Table BUC-2.--Lithofacies description of core from Johnson Unit 14-14 No. 1 well, F'ermit No. 2753, Bucatunna Creek field, Alabama (see figure BUC-7) -- Continued

Maximum porosity: 11.9

Minimum porosity: 7.7

Porosity standard deviation: 1.8

Number of analyses: 5

Geometric mean permeability $(\mathrm{md}): 0.42$

Maximum permeability (md): 1.61

Minimum permeability (md): 0.07

Number of analyses: 5

Depositional Environment: Flood-tidal delta.

Diagenesis: Reservoir originally resembled that of lithofacies 1, but substantial amounts of primary interparticle porosity have been preserved in lithofacies 2 . In addition, this lithofacies has been strongly overprinted by stylolitization, dissolution (mostly fabric selective) and growth of replacive anhydrite laths and stylocumulates. Early overcompaction was more extensive than in lithofacies 1. Early formation of micritic meniscus cement indicates a brief period of subaerial exposure, probably before deposition of the overlying strata of lithofacies 4 , which were deposited in a coastal sabkha. Formation of this early cement was followed by precipitation of marine-phreatic aragonitic rim cement which left many pores still open but which destroyed interparticle pore throats.

Percent of Reservoir: 23

Depth interval(s) (ft): $12,249-12,256$

Lithofacies 3: Oolitic pellet grainstone and pelletal ooid grainstone

Pore types:

Pelmoldic: $50 \%$

Oomoldic: $45 \%$

Interparticle: $5 \%$

Mean porosity (\%): 25.2

Maximum porosity (\%): 31.2

Minimum porosity (\%): 18.1

Porosity standard deviation (\%): 4.1

Number of analyses: 8

Geometric mean permeability (md): 2.94

Maximum permeability (md): 12.80

Minimum permeability (md): 0.91

Number of analyses: 8 
Table BUC-2.--Lithofacies description of core from Johnson Unit 14-14 No. 1 well, Permit No. 2753, Bucatunna Creek field, Alabama (see figure BUC-7) -- Continued

Depositional Environment: Backshoal subtidal lagoon grading up into washover or floodtidal delta.

Diagenesis: Early marine carbonate rim cementation was followed by slight local overcompaction, pore-filling carbonate cementation, and preservation of minor interparticle porosity at the base of the reservoir. Subsequent leaching of particles generated the present reservoir pore system; minor dolomitization and growth of replacive anhydrite laths did not materially affect the pore system.

Percent of Reservoir: 13

Depth interval(s) (ft): $12,272-12,276$

Lithofacies 4: Silty anhydritic ooid dolograinstone

Pore types:

Oomoldic: dominant ${ }^{*}$

Pelmoldic: minor

Secondary intraparticle: minor

*Accurate percentages indeterminable.

Mean porosity (\%): 13.0

Maximum porosity (\%): 24.3

Minimum porosity (\%): 7.9

Porosity standard deviation (\%): 7.6

Number of analyses: 4

Geometric mean permeability (md): 0.95

Maximum permeability (md): 6.60

Minimum permeability (md): 0.41

Number of analyses: 4

Depositional Environment: Tidal flat/coastal sabkha.

Diagenesis: Early diagenesis included local overcompaction with particle deformation (flattening); generation of the pore system consisted of pervasive dolomitization of cement and of some particles, followed by leaching of nondolomitized particles.

Subsequent growth of replacive nodular anhydrite, and anhydrite cementation in some oomolds, partially occluded the resenvoir; subhorizontal nodules composed of euhedral dolomite crystals and very small anhydrite laths in subequal proportions may be caliche crusts.

Percent of Reservoir: 12, but includes intercalated nodular anhydrite

Depth interval(s) (ft): $12,242-12,246$ 


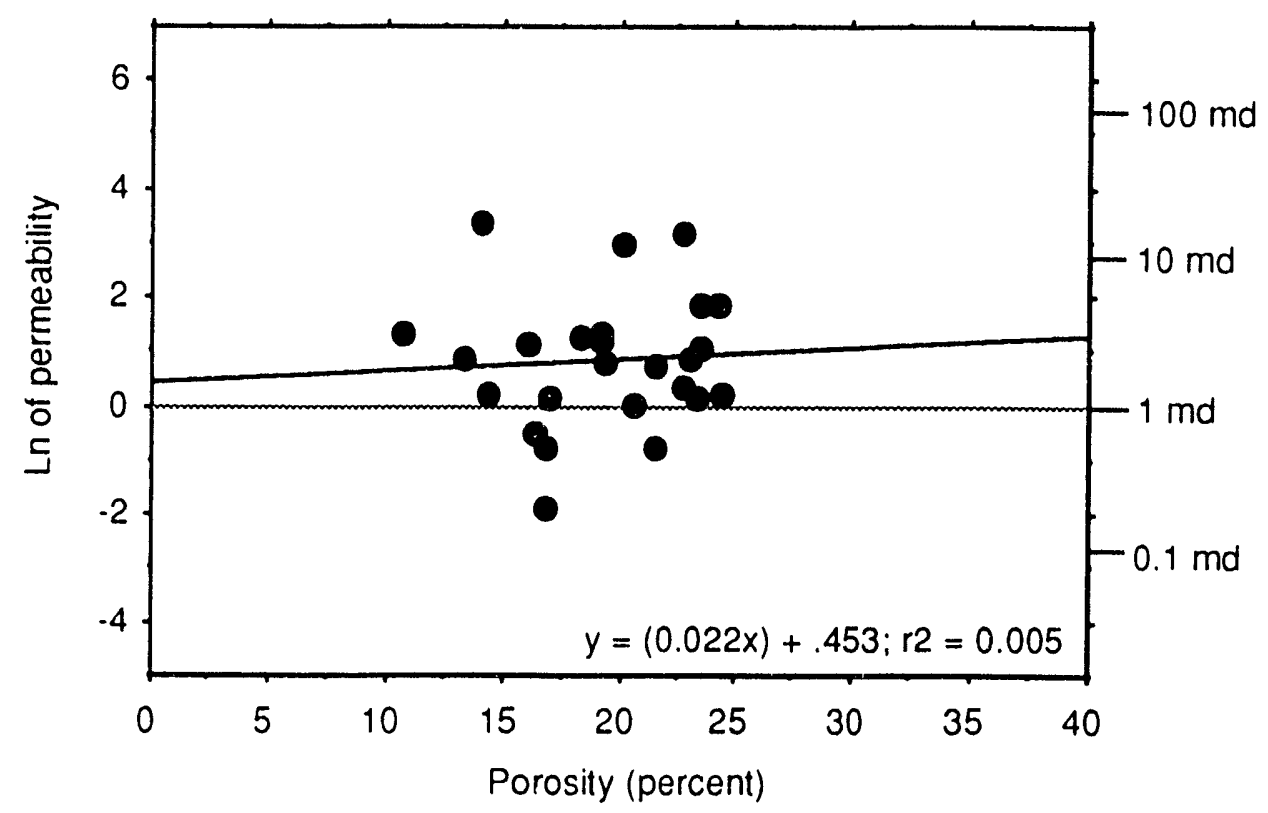

Figure BUC-8.--Porosity vs, natural log permeability plot for lithofacies 1, Johnson Unit 14-14 No. 1 well, Permit No. 2753-B. Bucatunna Creek field, Alabama. The other three lithofacies were represented by too few samples to yield interpretable graphs. Equation applies to regression line. (See table BUC-2 for descriptions of lithofacies.) Data set excludes all samples with porosity values and permeability values below reservorr cutotts at $6 \%$ and $0.1 \mathrm{md}$, respectively. 


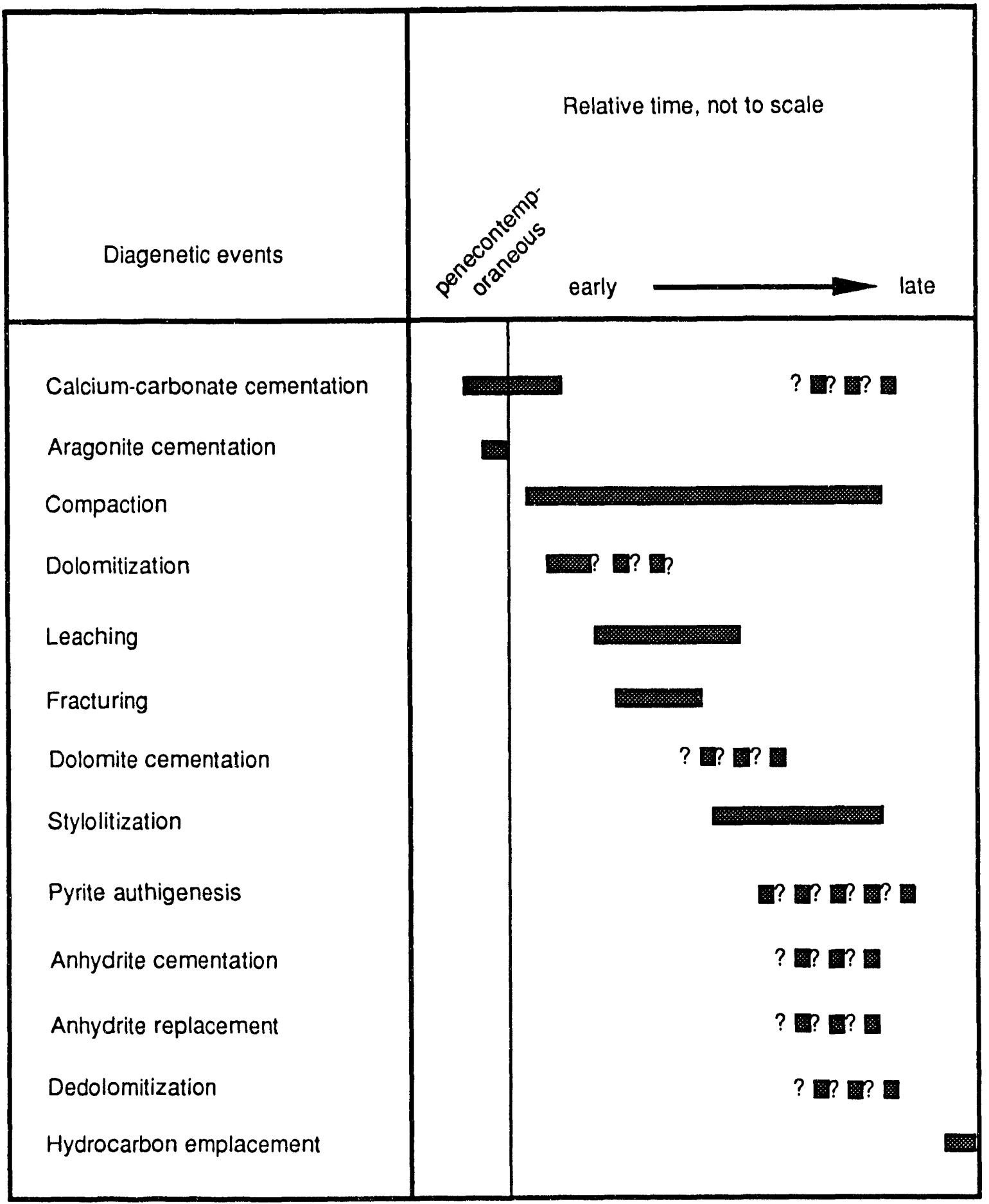

Figure BUC-9.--Paragenetic sequence, Johnson Unit 14-14 No. 1 well, Permit No. 2753, Bucatunna Creek field, Alabama. 


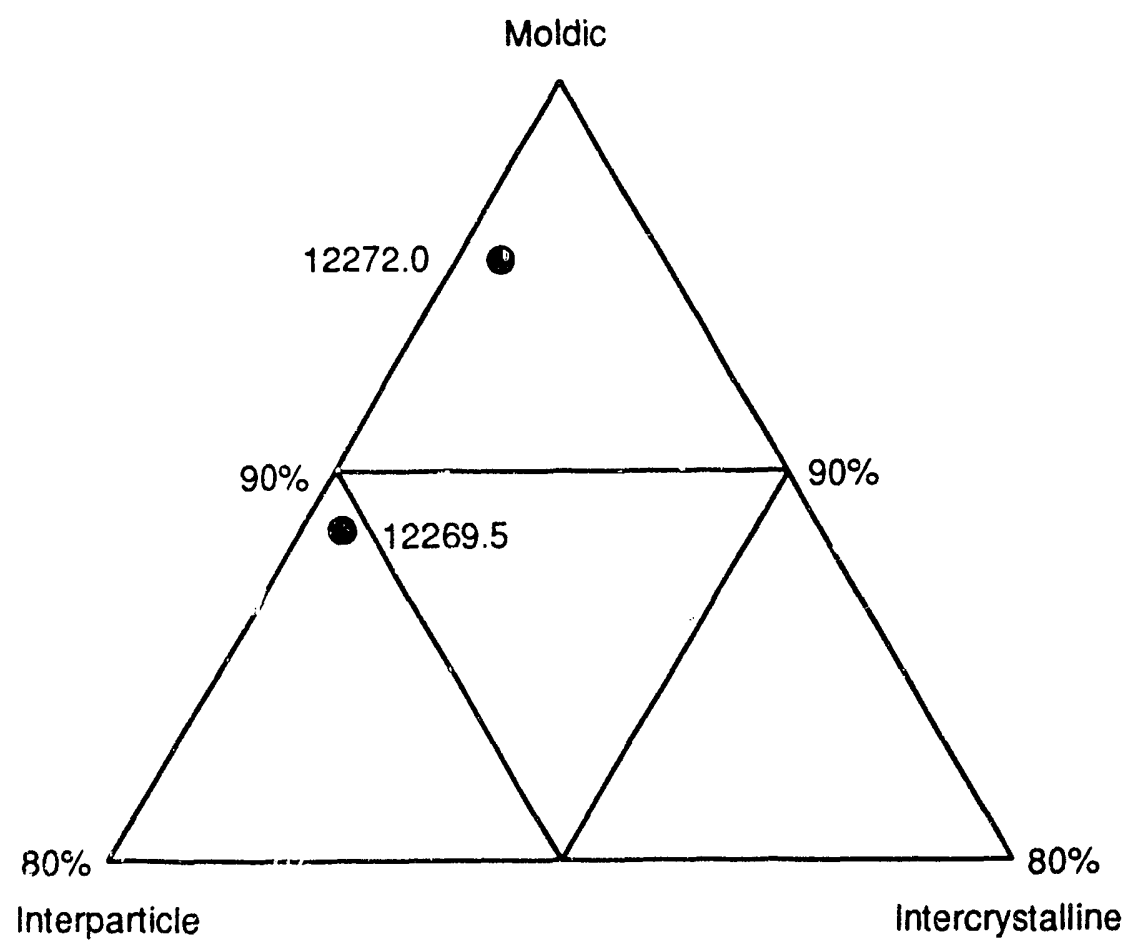

Figure BUC-10.--Ternary diagram of pore types, Johnson Unit 14-14 No. 1 well, Permit No. 2753, Bucatunna Creek field, Alabama. Percentages of moldic pores indicated.

Sample depths are indicated to nearest 0.1 foot. 
BURNT CORN CREEK FIELD

SMACKOVER OIL POOL

ESCAMBIA COUNTY, ALABAMA 


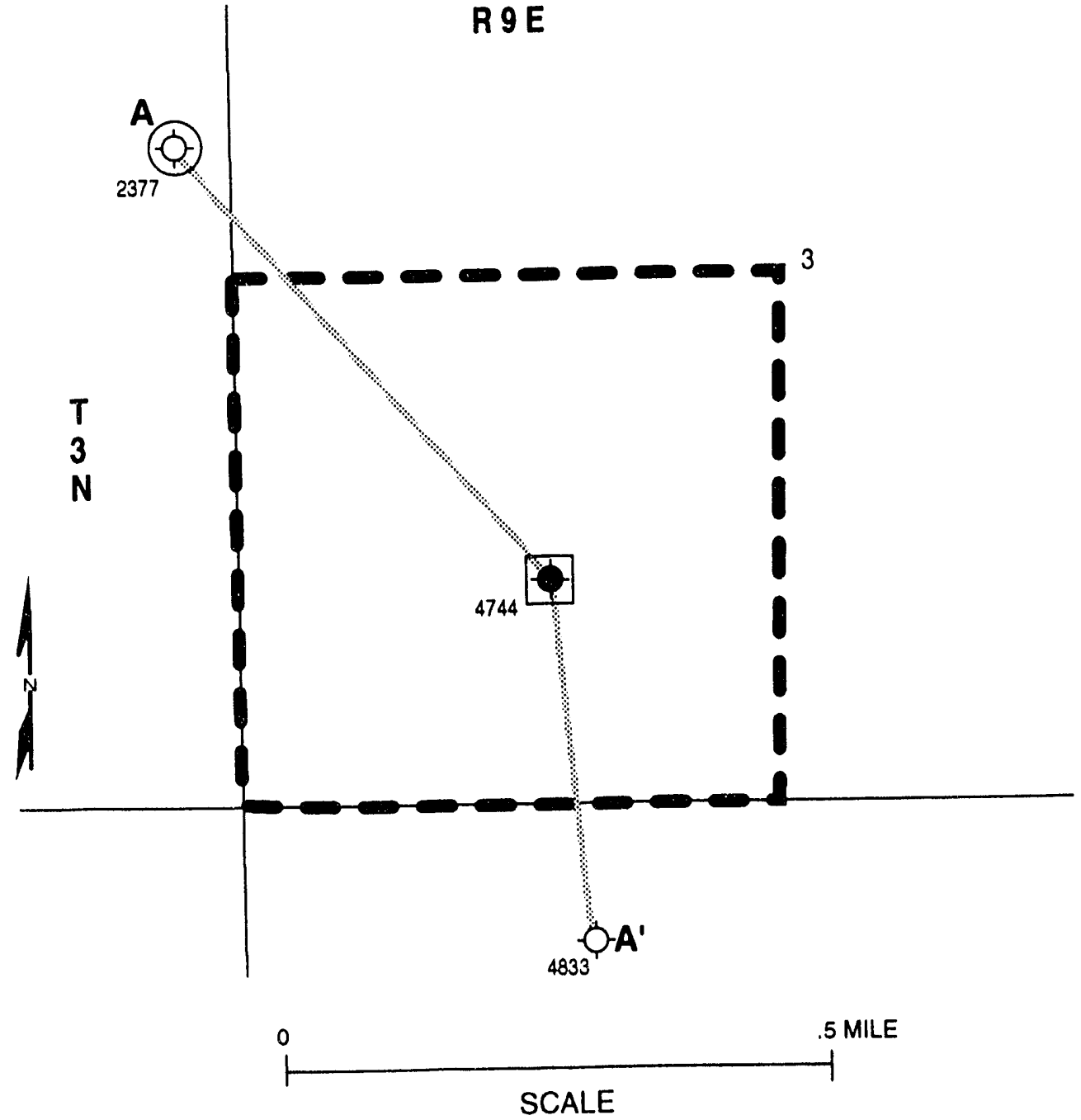

Figure BCC-1.--Index map of Burnt Corn Creek field, Alabama. 


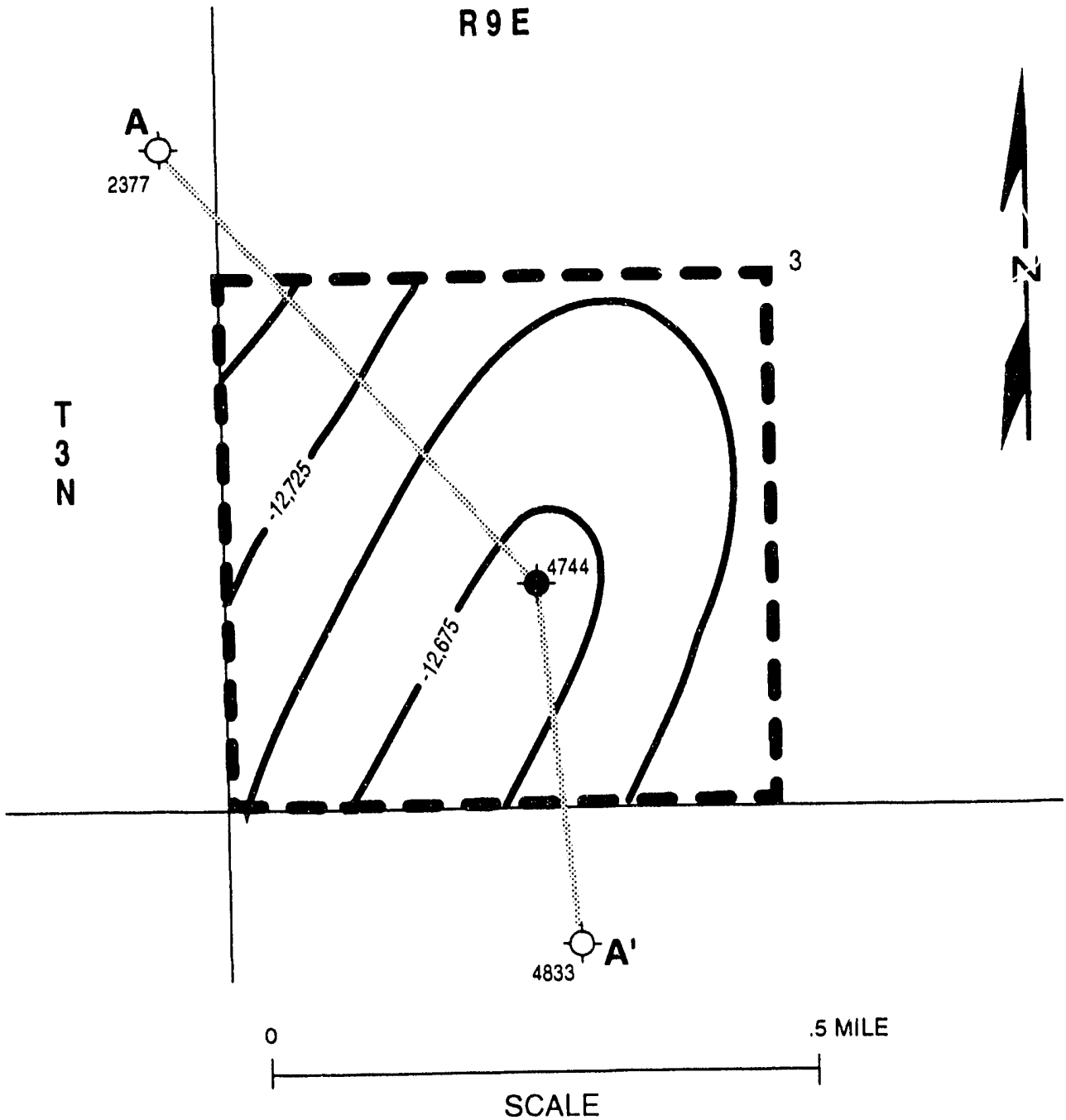

Figure BCC-2.--Structure contour map on top of Smackover Formation in Burnt Corn Creek field, Alabama. 


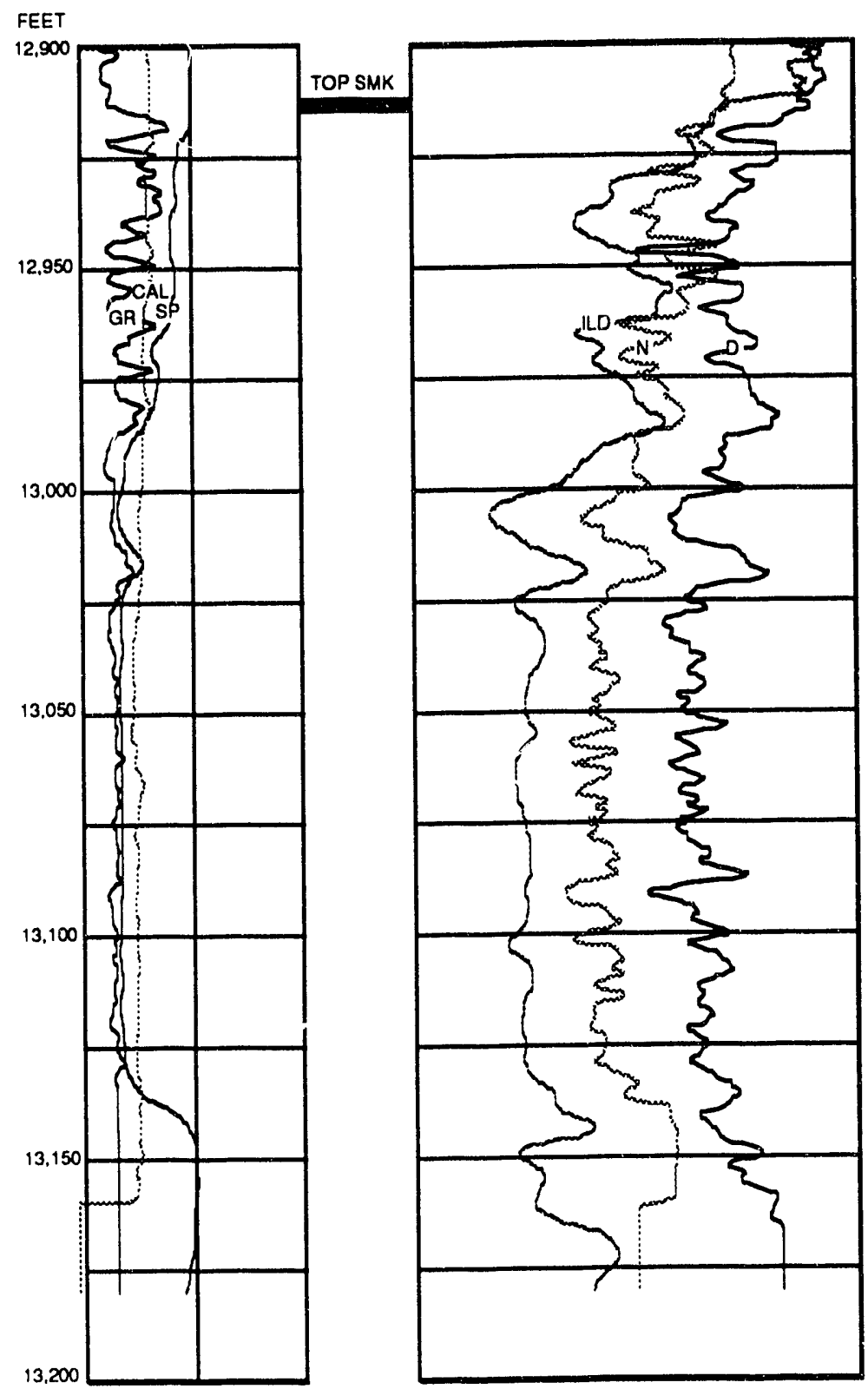

Figure BCC-3.--Well log, A.J. Smith 3-14 No. 1 well, Permit No. 4744 , Burnt Corn Creek field, Alabama. 


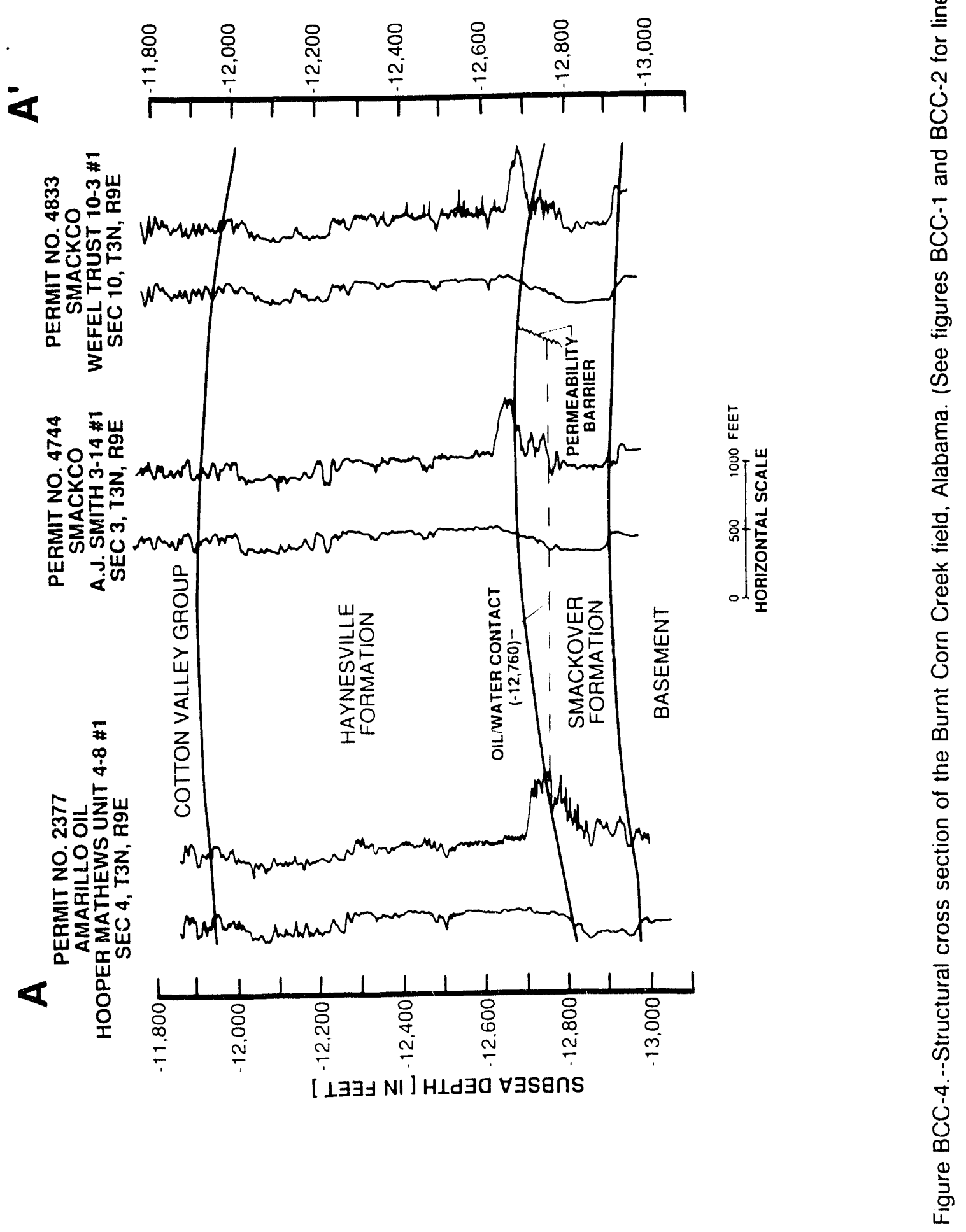




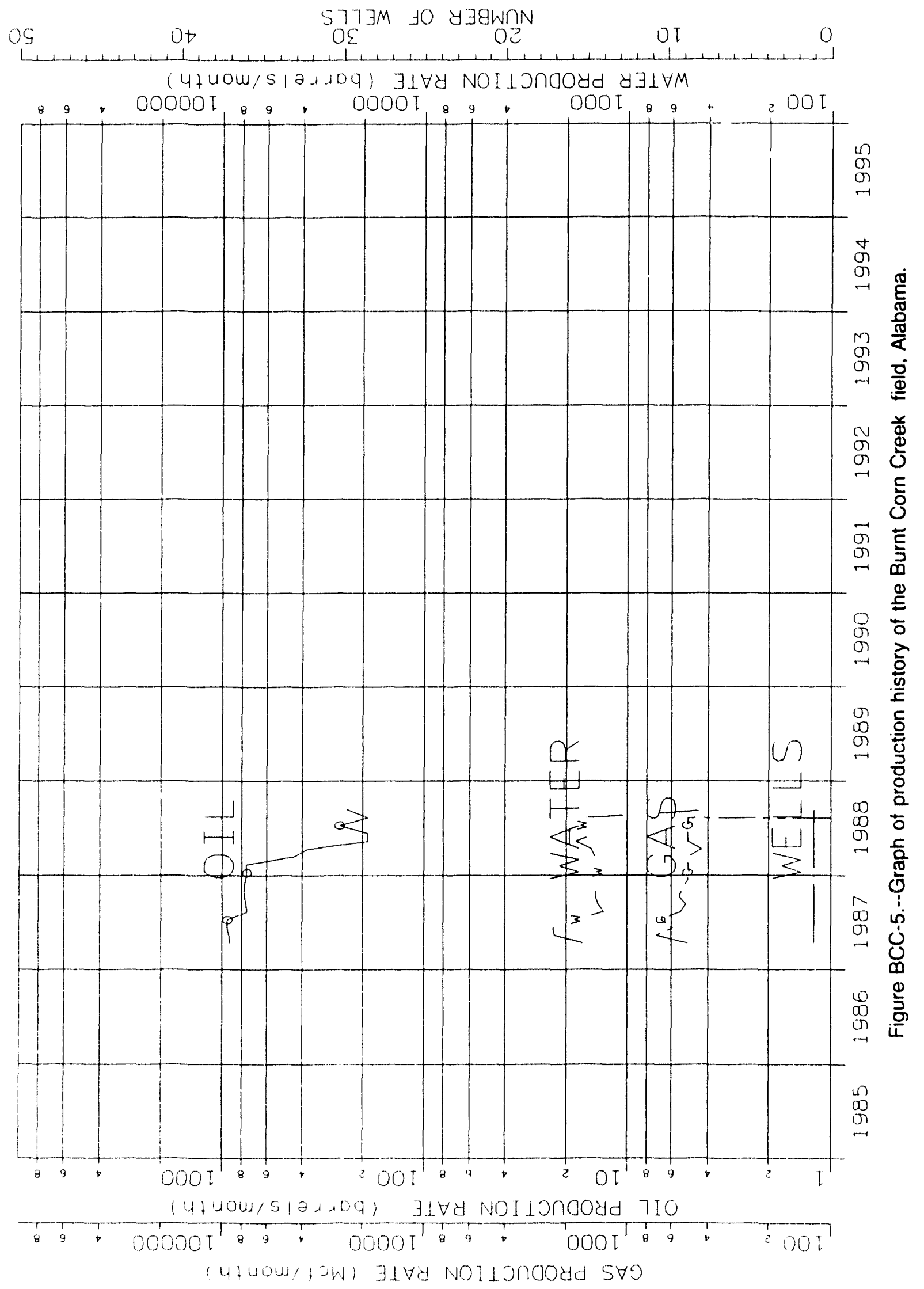


Table BCC-1.--Reservoir characterization sheet, Smackover pool, Burnt Corn Creek field, Escambia County, Alabama

\section{Discovery well}

Operator: Smackco, Ltd.

Permit number: 4744

Well Name: A.J. Smith 3-14 \#1

Location: Sec. 3, T3N-R9E

Completion date: $11 / 06 / 85$

Perforations: $12,920-12,980 \mathrm{ft}$

Initial flow rate: 120 bopd, 135 Mcfd, 18/64 ck, 255 psi

Field data (as of $12 / 31 / 90$ )

Number of wells within field limits: 1

Producing wells in pool: 0

Production wells in field: 0

Shut-in/Temp. abandoned wells: 0

Plugged and abandoned wells: 1

Salt water disposal wells: 0

Enhanced recovery wells: 0

Dry holes: 0

Drilling wells: 0

Unit spacing (acres): 160

Total field area (acres): 160

Cumulative production

Oil (bbl): 10,911

Gas (Mcf): 9,038

Water (bbl): 27,710

\section{Reservoir data}

Trap type: Stuctural / stratigraphic

Reservoir structure: Anticline

Proven productive area (acres): 162

Average net pay thickness (feet): na

Hydrocarbon type: Oil

Oil gravity (API): 49

Initial reservoir pressure (psia): 6,123

Current reservoir pressure (psia): 5,909

Reservoir drive: Solution gas / water

Type of enhanced recovery: none

Mean porosity (core) (\%): na

Porosity standard deviation (\%): na

Maximum porosity (\%): na

Minimum porosity (\%): na

Number of porosity analyses: na

Geometric mean perm (core) (md): na

Permeability standard deviation (\%): na

Maximum permeability (md): na

Minimum permeability (md): na

Number of permeability analyses: na

Dykstra-Parsons coefficient: na 


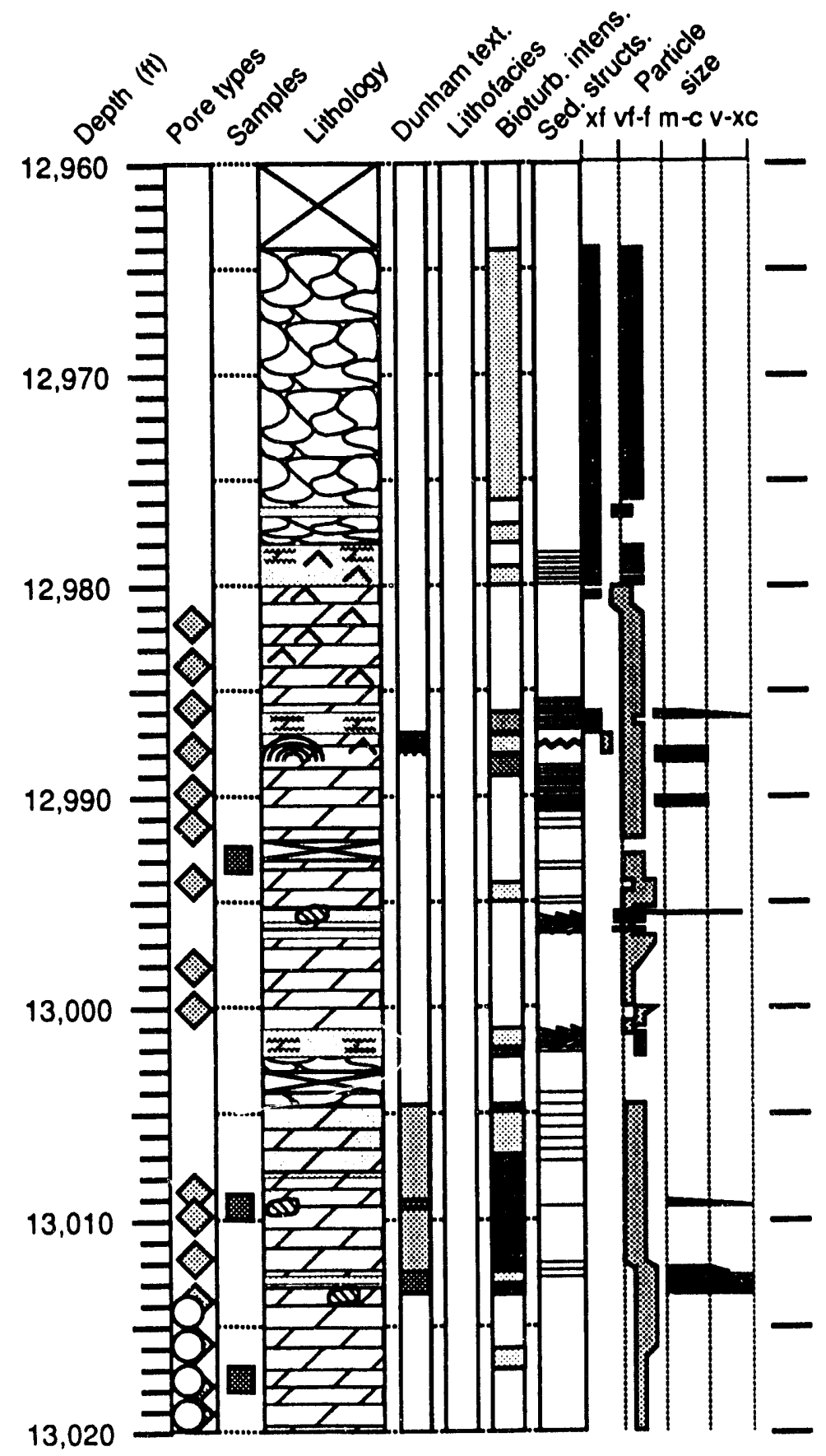

Figure BCC-6.--Detailed core log, Hooper Mathews 4-8 No. 1 well, Permit No. 2377, Burnt Corn Creek field, Alabama. 
Table BCC-2.--Lithofacies description of core from Hooper Mathews 4-8 No. 1 well, Permit No. 2377. Bumt Corn Creek field, Alabama (see figure BCC-7)

Lithofacies 1: Very fine to fine planar-s dolostone (hypidiotopic dolostone)

Pore types:

Intercrystalline: $55 \%$

Outsize: $45 \%$

Depositional Environment: Subtidal flat.

Diagenesis: Pervasive and fabric destructive dolomitization is the most obvious diagenetic process. Uncommon and small fractures are filled with anhydrite cement. Late calcite cement fills a few intercrystalline pores locally.

Percent of reservoir: 100

Depth interval(s) (tt): $13,013.5-13,020$ 


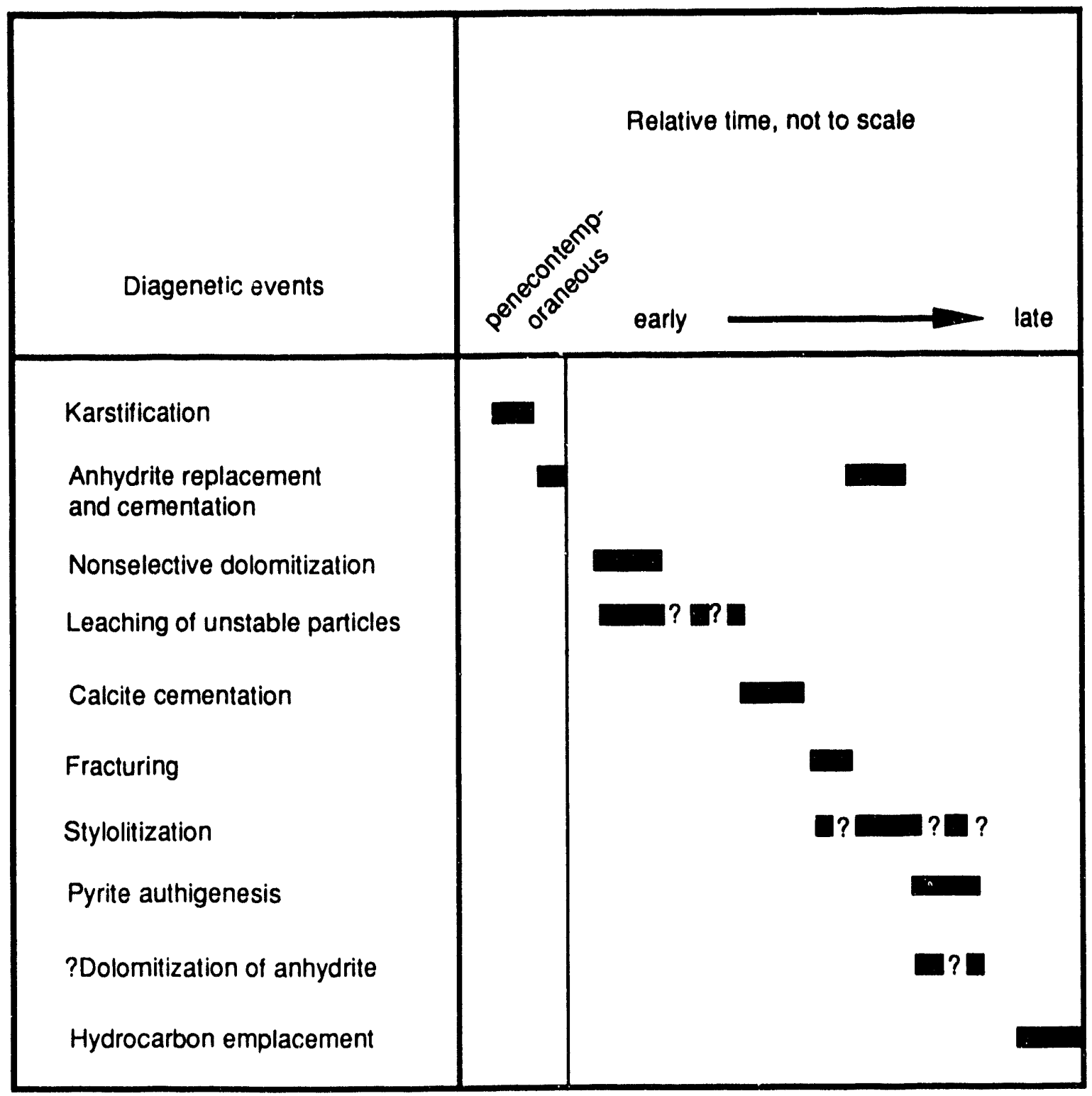

Figure BCC-7.--Paragenetic sequence, Hooper Mathews 4-8 No. 1 well, Permit No. 2377, Burnt Corn Creek field, Alabama. 


\section{CHAPPELL HILL FIELD}

SMACKOVER OIL POOL

CHOCTAW COUNTY, ALABAMA 


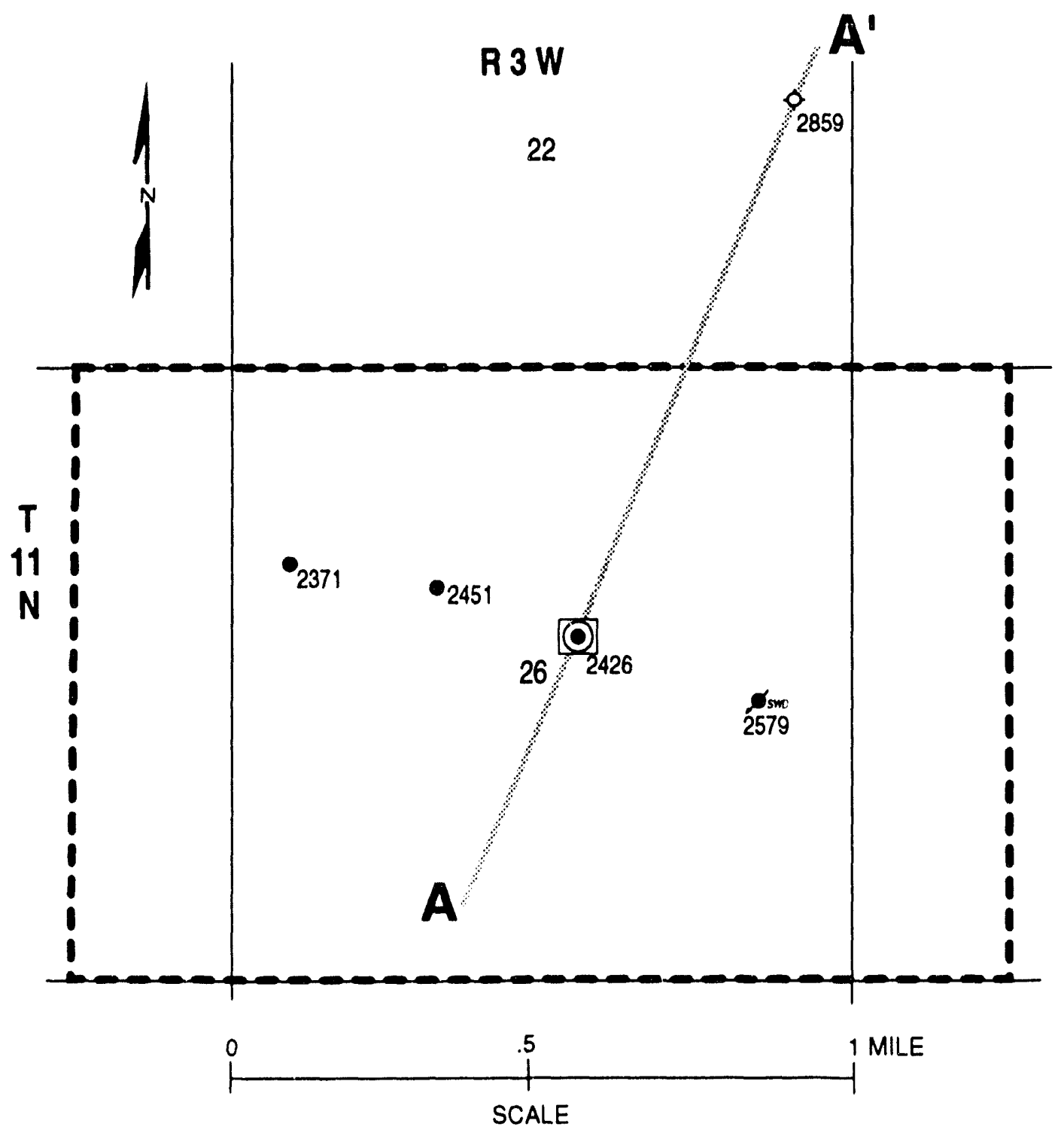

Figure $\mathrm{CH} \cdot 1 .--$ Index map of Chappell Hill field, Alabama. 


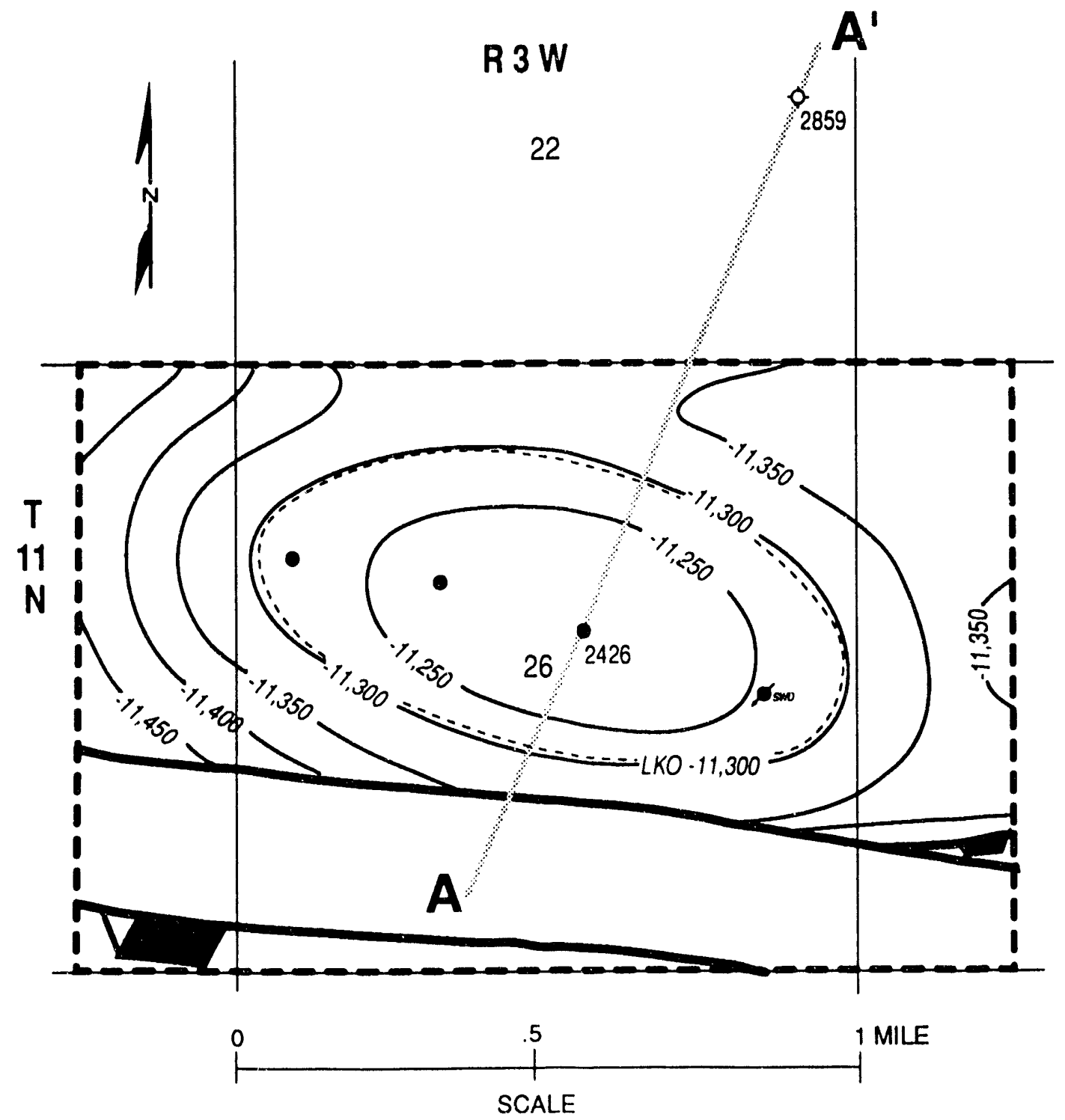

Figure $\mathrm{CH}-2$.--Structure contour map on top of Smackover Formation in Chappell Hill field, Alabama. 
FEET

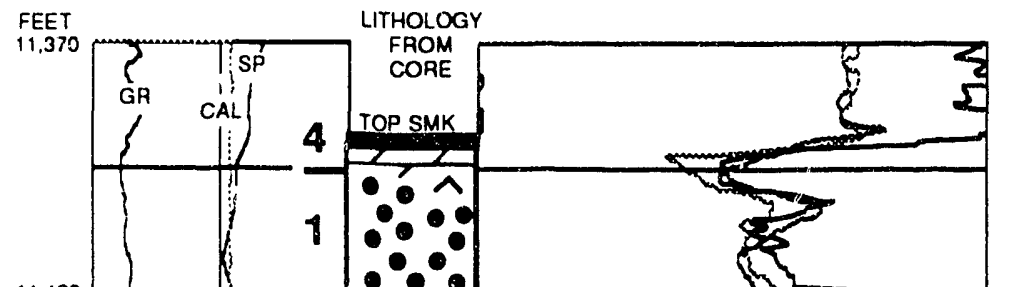

$11,420+1$

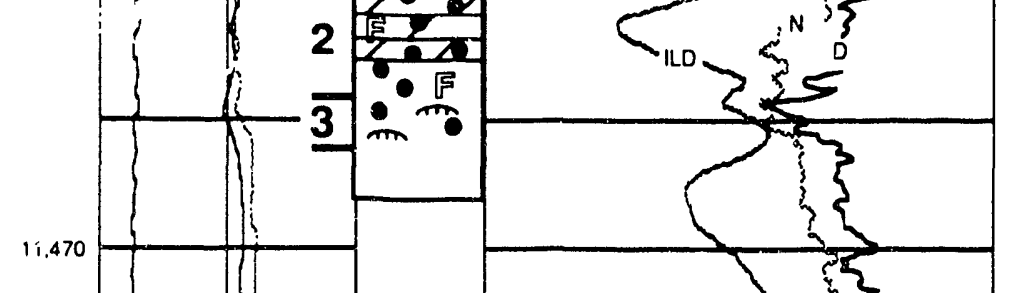

.
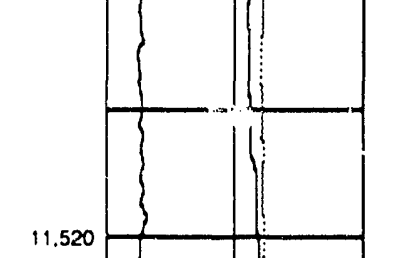

11,520
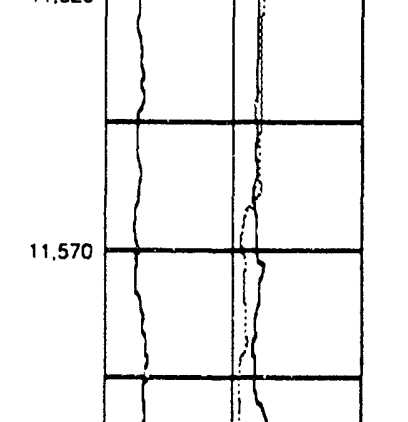

11.20
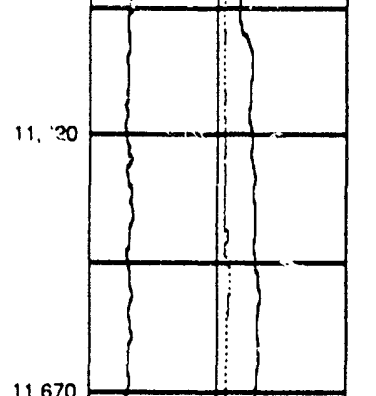

11,670
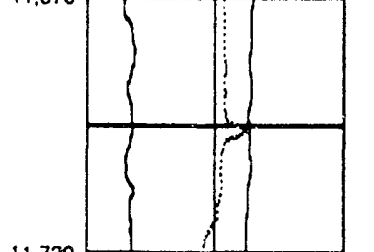

11,720

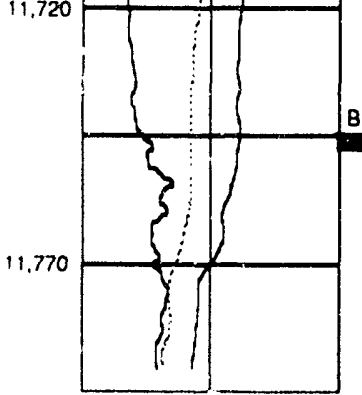

BंSE SMK

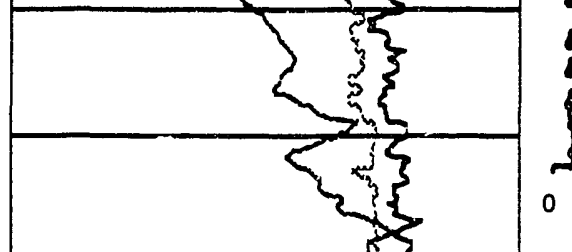

$5 \times$

$3\}$

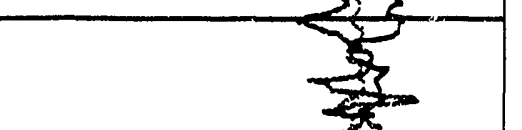

CORE DERIVEDPOROSITY AND PEBMEABULITY
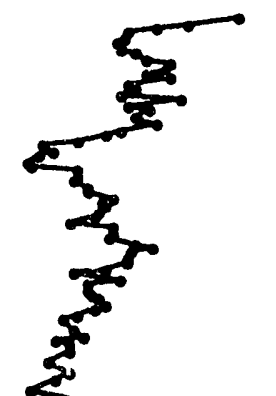

$\sum_{1}^{\infty}$

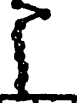

$\begin{array}{lllllllll}0 & 5 & 15 & 25 & 35 & .1 & 1 & 10 & 100\end{array}$

POROSITY (percent)

PERMEABILITY (md)

Figure $\mathrm{CH}-3$.--Well log correlated to lithology, porosity, and permeability, Bolinger 26-7 No. 1 well, Permit No. 2426, Chappell Hill field: Alabama. 


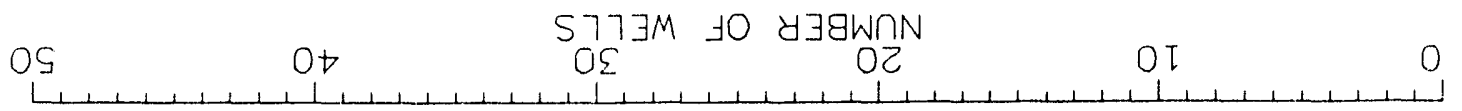

( $4+40 m / s \mid \partial \perp \lambda D$ ) $\exists \perp \forall y$ NOI $\perp$ OnoOyd $\forall \exists \perp \forall M$

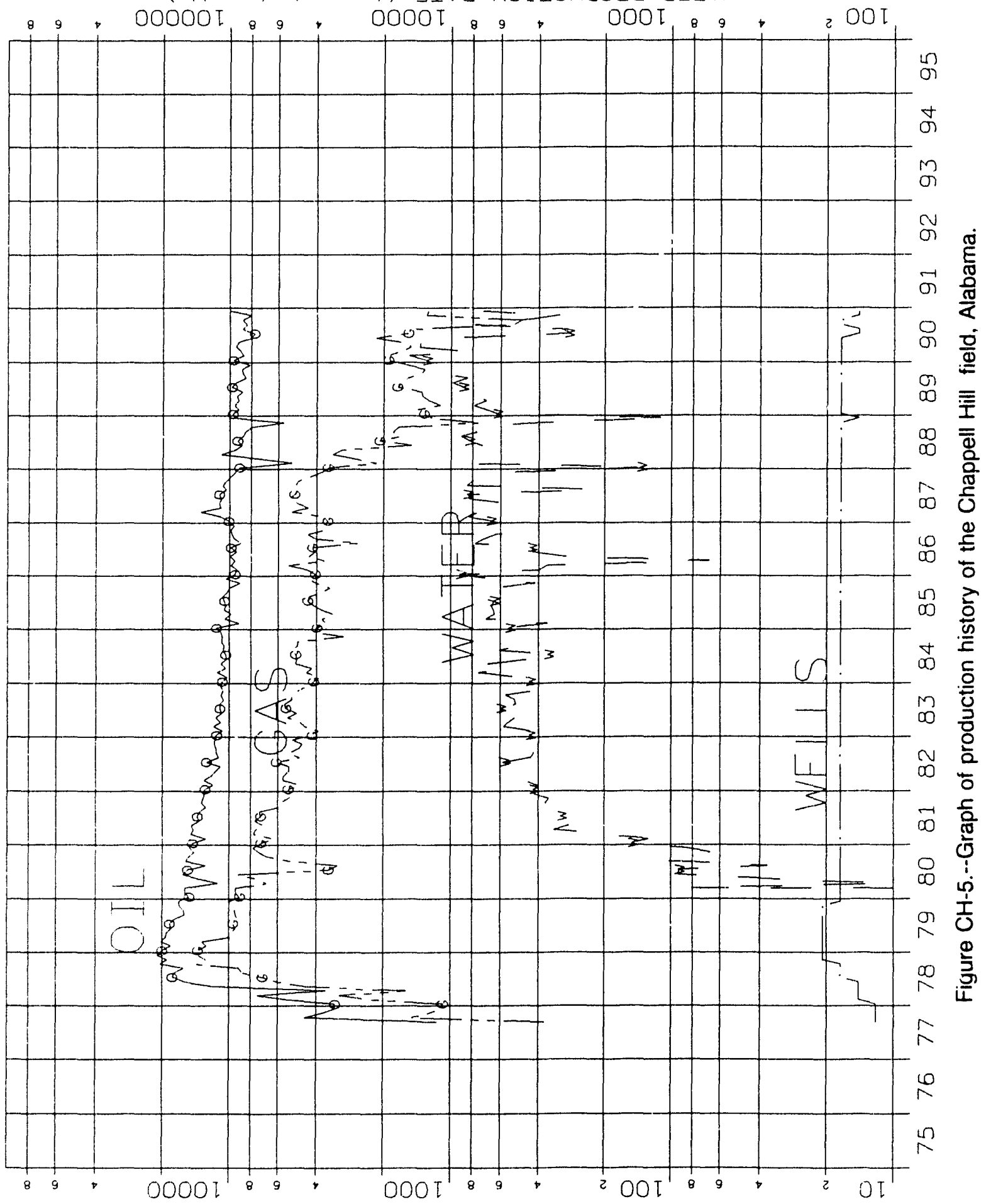

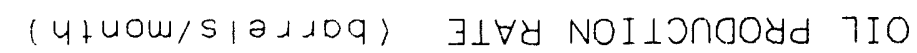

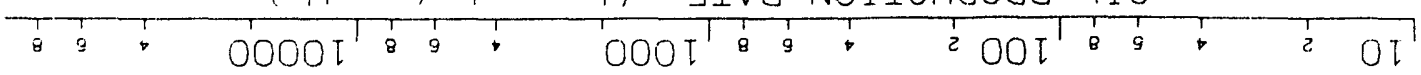

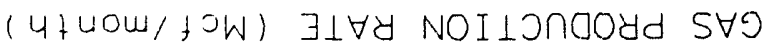



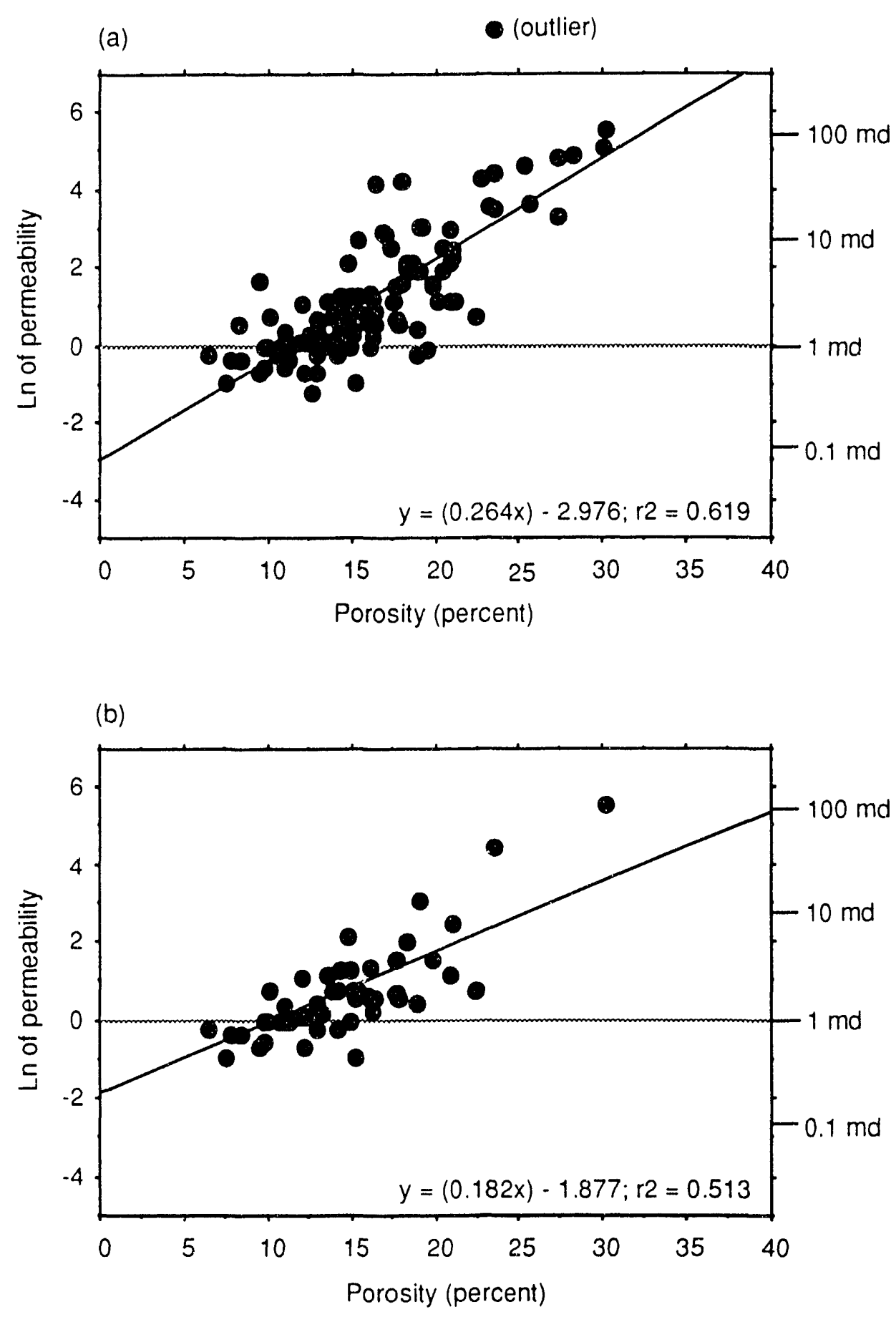

Figure $\mathrm{CH}-6$.--Porosity vs. natural log permeability plots, Chappell Hill field, Alabama. (a) Plot of three cores combined, and (b) plot of described core for Bolinger 26-7 No. 1 well, Permit No. 2426. Equations apply to regression lines. 
Table CH-1.--Reservoir characterization sheet, Smackover pool, Chappell Hill field, Choctaw County, Alabama

\section{Discovery well}

Operator: Midroc Oil Co. - H.V. Watkins, Jr.

Permit number: 2371

Well Name: Jenkins 26-5 \#1

Location: Sec. 26, T11N-R3W

Completion date: 09/18/77

Perforations: $11,412-11,422 \mathrm{ft}$

Initial flow rate: 125 bopd, 16/64 ck,

$$
160 \mathrm{psi}
$$

Field data (as of 12/31/90)

Number of wells within field limits: 4

Producing wells in pool: 3

Production wells in field: 3

Shut-in/Temp. abandoned wells: 0

Plugged and abandoned wells: 0

Salt water disposal wells: 1

Enhanced recovery wells: 0

Dry holes: 0

Drilling wells: 0

Unit spacing (acres): 120

Total field area (acres): 960

Cumulative production

Oil (bbl): 1,808,901

Gas (Mcf): 764,644

Water (bbl): 721,390

\section{Reservoir data}

Trap type: Stuctural

Reservoir structure: Faulted anticline

Proven productive area (acres): 256

Average net pay thickness (feet): 33

Hydrocarbon type: Oil

Oil gravity (API): 38

Initial reservoir pressure (psia): 5,178

Current reservoir pressure (psia): 3,451

Reservoir drive: Solution gas / water

Type of enhanced recovery: none

Mean porosity (core) (\%): 16.20

Porosity standard deviation (\%): 4.93

Maximum porosity (\%): 30.10

Minimum porosity (\%): 6.40

Number of porosity analyses: 109

Geometric mean perm (core) (md): 3.64

Maximum permeability (md): $3,605.00$

Minimum permeability (md): 0.3

Number of permeability analyses: 109

Dykstra-Parsons coefficient: na 


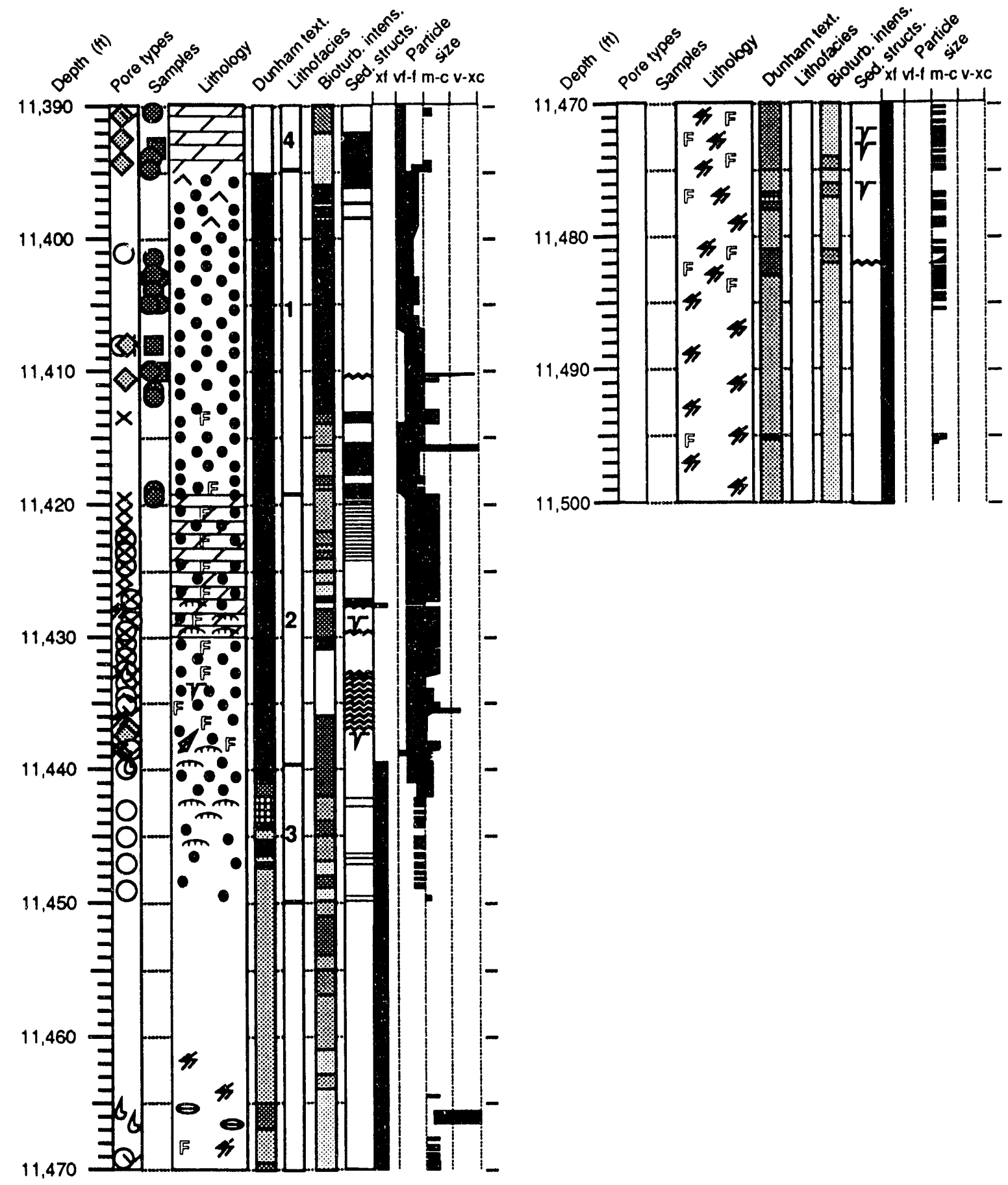

Figure $\mathrm{CH}-7$.--Detailed core log, Bolinger 26-7 No. 1 well, Permit No. 2426, Chappell Hill field, Alabama. 
Table CH-2.-- Lithofacies description of core from Bolinger 26-7 No. 1 well, Permit No. 2426, Chappell Hill field, Alabama (see figure $\mathrm{CH}-7$ )

Lithofacies 1: Pellet grainstone

Pore types:

Moldic: major*

Intercrystalline: major

Interpanticle: minor-major

Secondary intraparticle: minor

"Accurate percentages indeterminable.

Mean porosity (\%): 16.7

Maximum porosity (\%): 22.4

Minimum porosity (\%): 12.3

Porosity standard deviation (\%): 2.8

Number of analyses: 19

Geometric mean permeability (md): 2.11

Maximum permeability $(\mathrm{md}): 11.80$

Minimum permeability (md): 0.40

Number of analyses: 19

Depositional Environment: Restricted lagoon.

Diagenesis: Minor early dolomitization, growth of leniıcular gypsum in upper part, fair preservation of primary fabric.

Percent of reservoir: 41

Depth interval(s) (ft): $11,395-11,419$

Lithofacies 2: Favreina-bearing small-pellet grainstone and Favreina-bearing small-pellet dolograinstone

Pore types:

Moldic: $43 \%$

Secondary intraparticle: $36 \%$

Intercrystalline: $8 \%$

Vuggy: $7 \%$

Fracture: $4 \%$

Cement moldic: $2 \%$

Mean porosity (\%): 12.7

Maximum porosity (\%): 18.3

Minimum porosity $(\%): 7.5$

Porosity standard deviation (\%): 2.7 
Table CH-2.-- Lithofacies description of core from Bolinger 26-7 No. 1 well, Permit No. 2426 , Chappell Hill field, Alabama (see figure $\mathrm{CH}-7$ ) -- Continued

Number of analyses: 17

Geometric mean permeability (md): 1.38

Maximum permeability (md): 7.50

Minimum permeability (md): 0.40

Number of analyses: 17

Depositional environment: Tidal flat.

Diagenesis: Pore system created by simultaneous dolomitization and leaching before deep burial. Fluids may have moved downward or laterally and may have been of mixed origin (mixingzone dolomitization).

Percent of Reservoir: 33

Depth interval(s) (ft): $11,419-11,439.5$

Lithofacies 3: Pellet packstone-grainstone

Pore Types:

Moldic: $100 \%$

Mean porosity (\%): 10.2

Maximum porosity (\%): 13.9

Minimum porosity (\%): 6.4

Porosity standard deviation (\%): 2.1

Number of analyses: 11

Geometric mean permeability (md): 1.10

Maximum permeability (md): 3.00

Minimum permeability (md): 0.50

Number of analyses: 11

Depositional environment: Shallow lagoon, increasing restriction upward.

Diagenesis: Leaching and associated minor dolomitization created the pore system.

Percent of reservoir: 18

Depth interval(s) (ft): $11,439.5-11,450$ 
Table CH-2.-- Lithofacies description of core from Bolinger 26-7 No. 1 well, Permit No. 2426, Chappell Hill field, Alabama (see figure CH-7) -- Continued

Lithofacies 4: Very finely crystalline dolostone

Pore types:

Intercrystalline: $70 \%$

Vuggy: $30 \%$

Mean porosity (\%): 20.5

Maximum porosity (\%): 30.1

Minimum porosity (\%): 14.8

Porosity standard deviation (\%): 6.4

Number of analyses: 5

Geometric mean permeability (md): 24.38

Maximum permeability (md): 265.00

Minimum permeability (md): 2.20

Number of analyses: 5

Depositional environment: Tidal flat.

Diagenesis: Early, pervasive dolomitization.

Percent of reservoir: 8

Depth interval(s): $11,390-11,395$ 
(a)

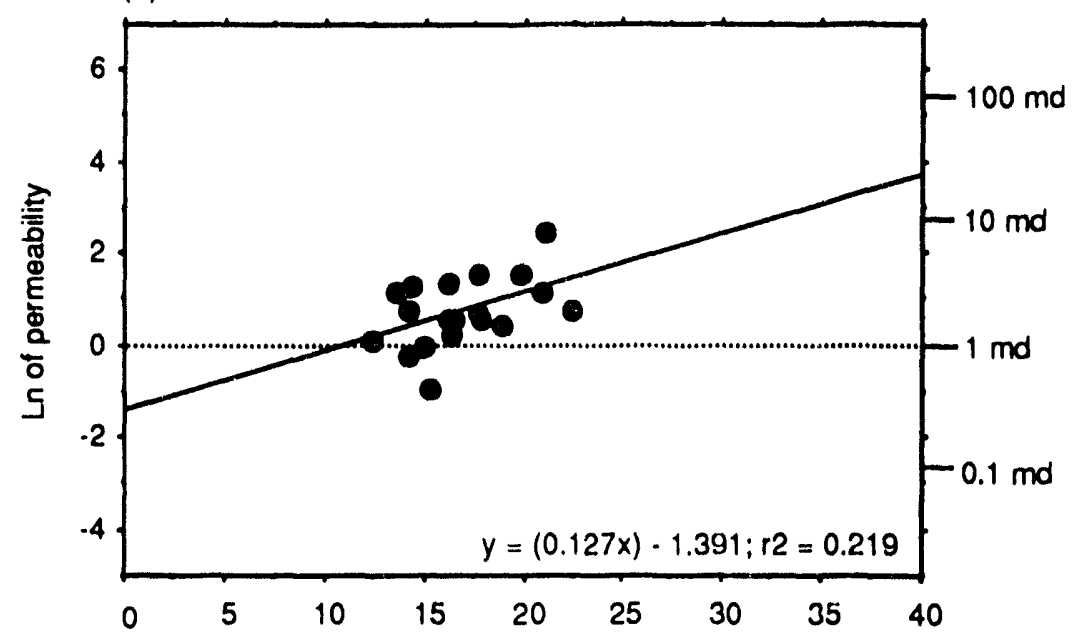

(b)

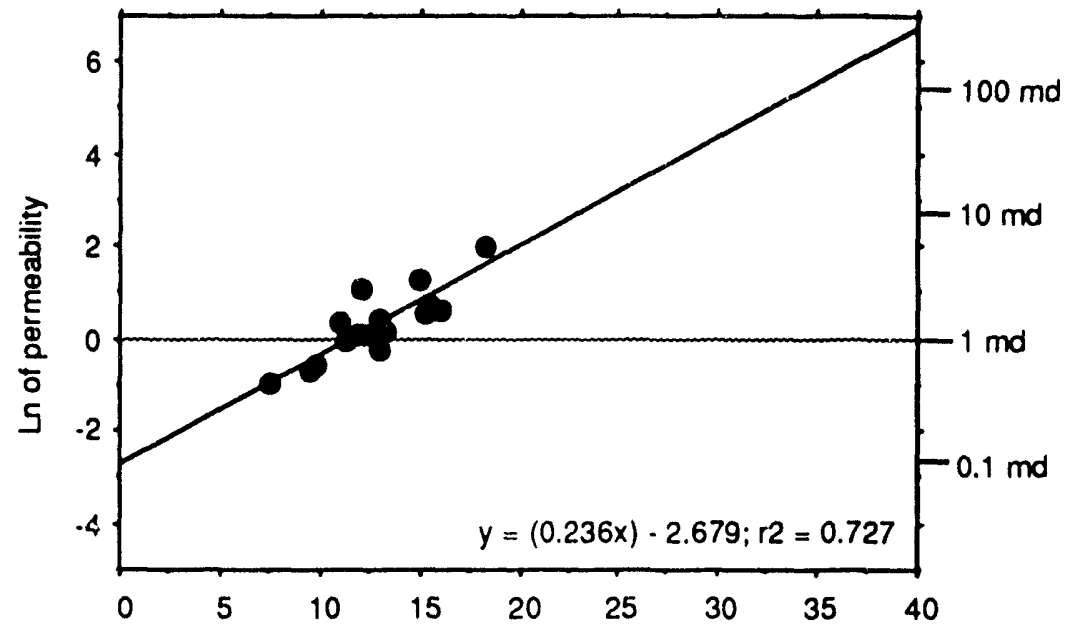

(c)

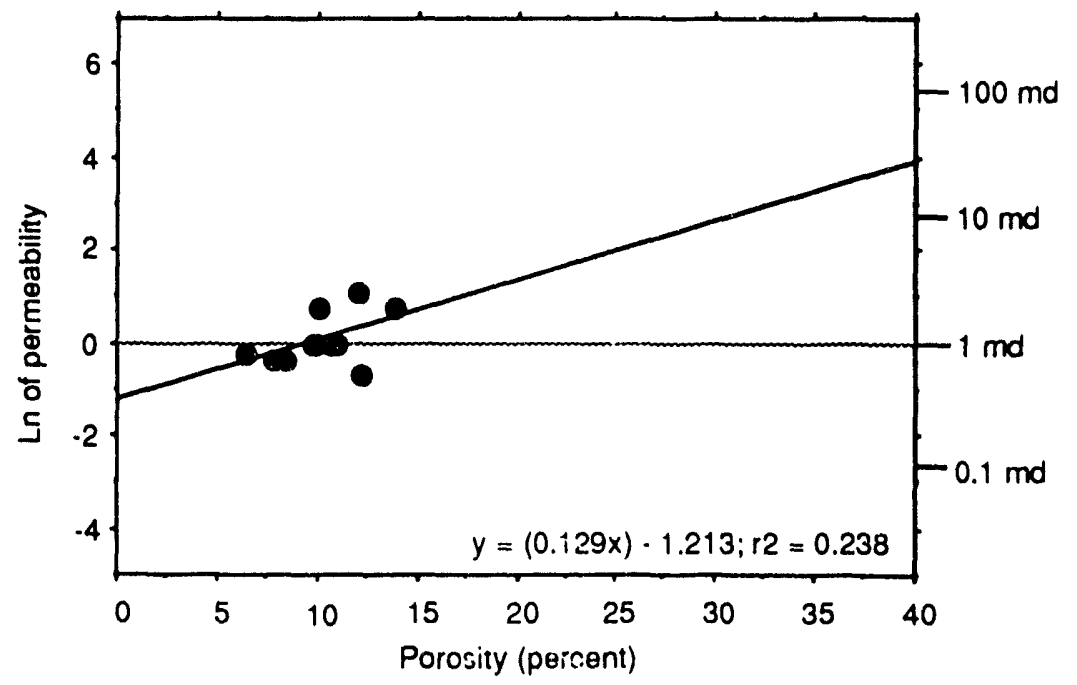

Figure $\mathrm{CH}-8$.-. Porosity vs. natural log permeability plots for lithofacies. Bolinger 26-7 No. 1 well, Permit No. 2426, Chappell Hill field, Alabama. (a) Lithofacies 1, (b) lithofacies 2, and (c) lithofacies 3. Equations for regression lines are printed for each lithofacies. (See table $\mathrm{CH}-2$ for descriptions of lithofacies.) 


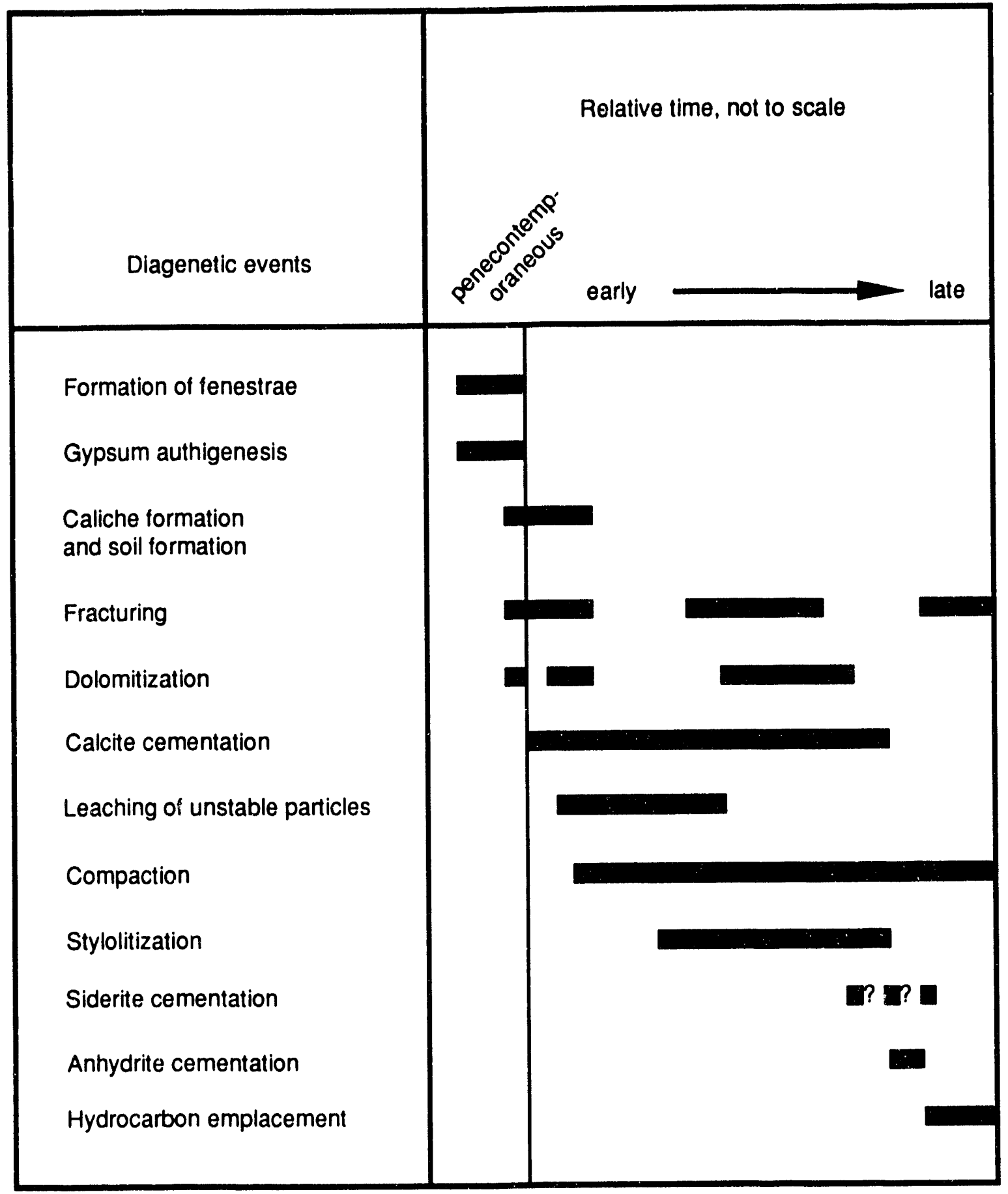

Figure $\mathrm{CH}-9$. .-Paragenetic sequence, Bolinger 26-7 No. 1 well, Permit No. 2426, Chappell Hill field, Alabama. 


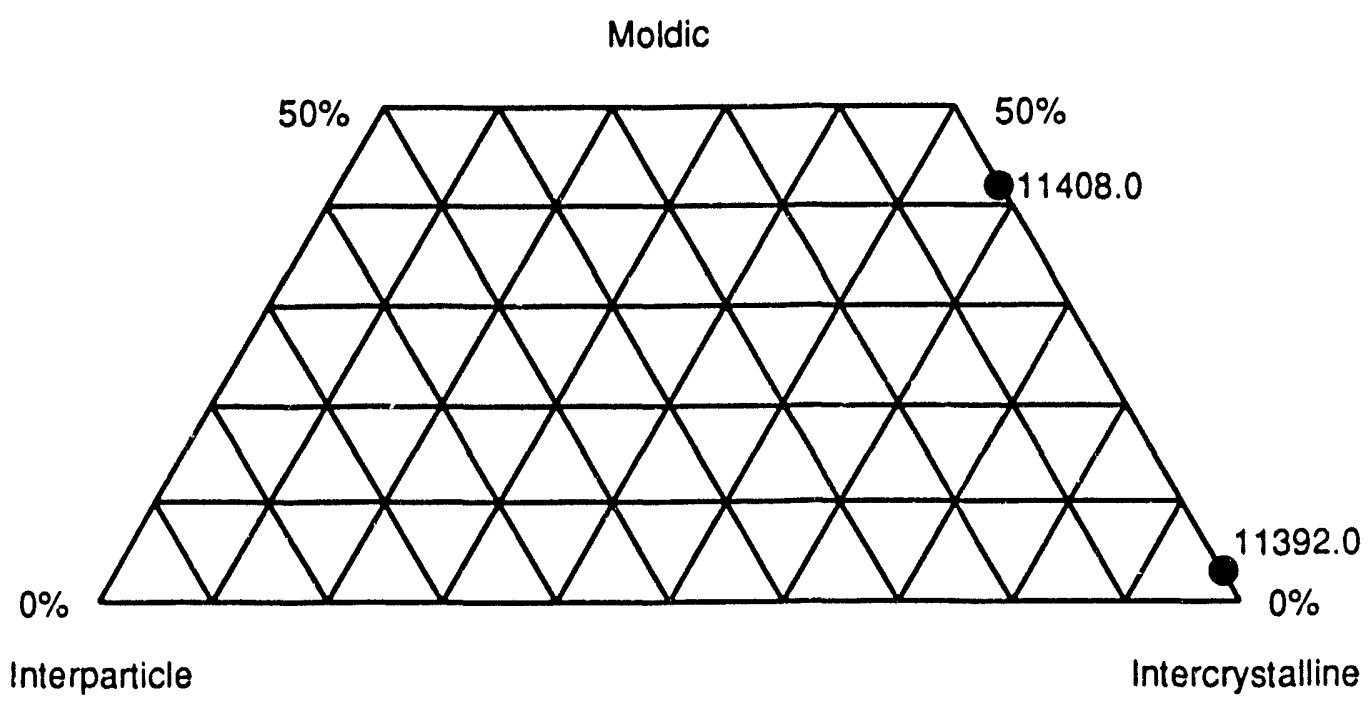

Figure $\mathrm{CH}-10 .--$ Ternary diagram of pore types, Bolinger 26-7 No. 1 well, Permit No. 2426, Chappell Hill field, Alabama. Percentages of moldic pores indicated. Sample depths are indicated to nearest 0.1 foot. 
CHATOM FIELD

SMACKOVER GAS AND CONDENSATE POOL

WASHINGTON COUNTY, ALABAMA 


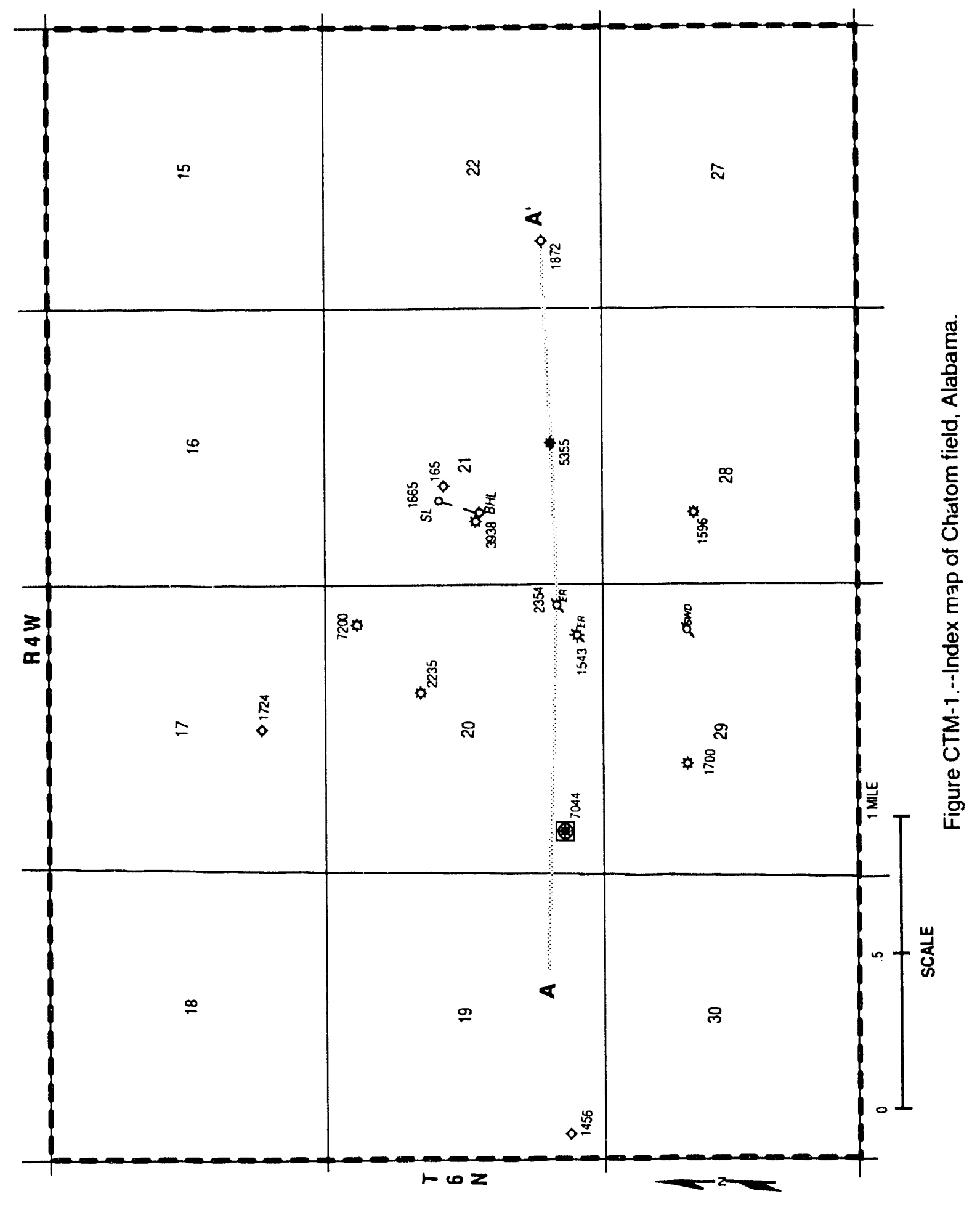




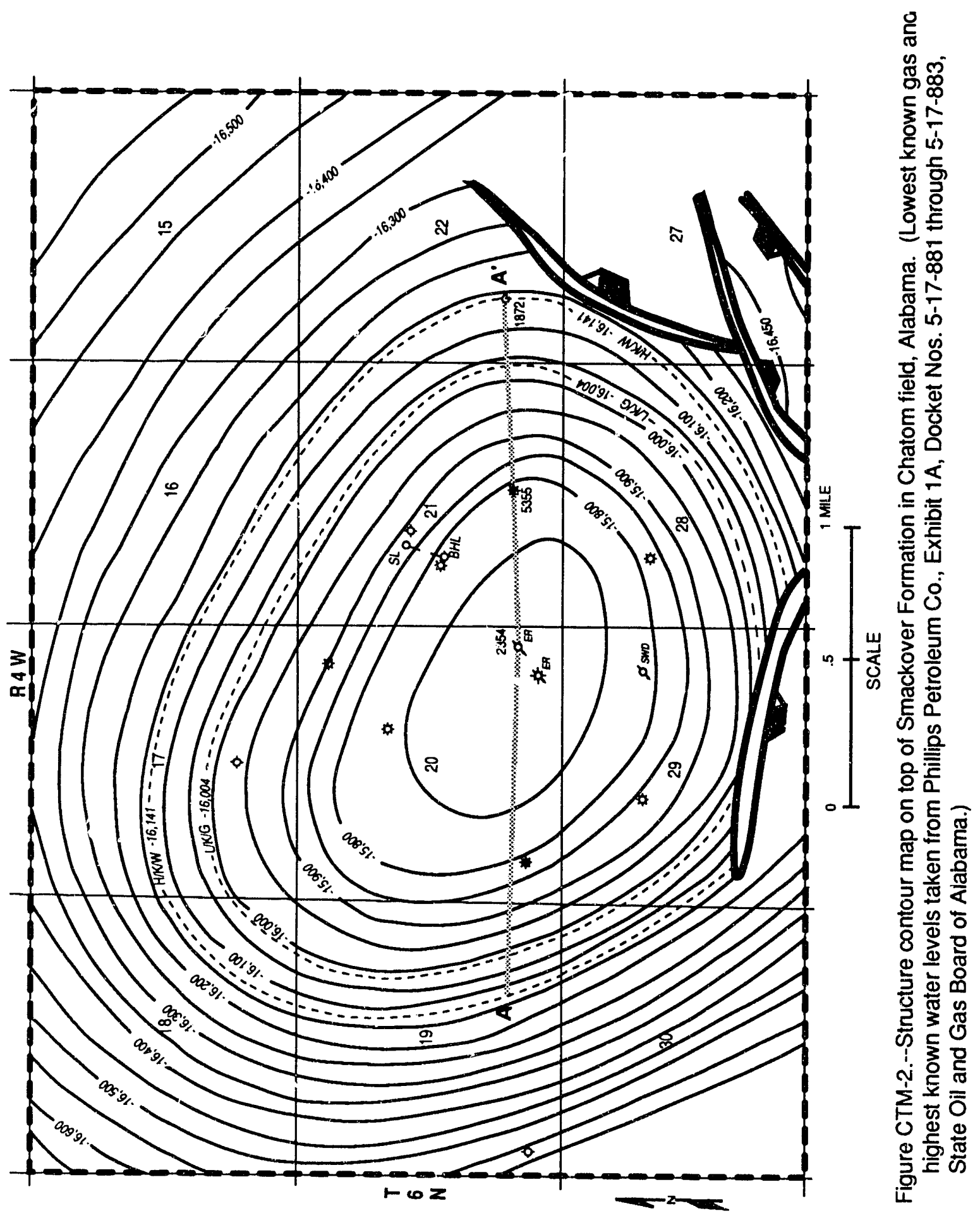




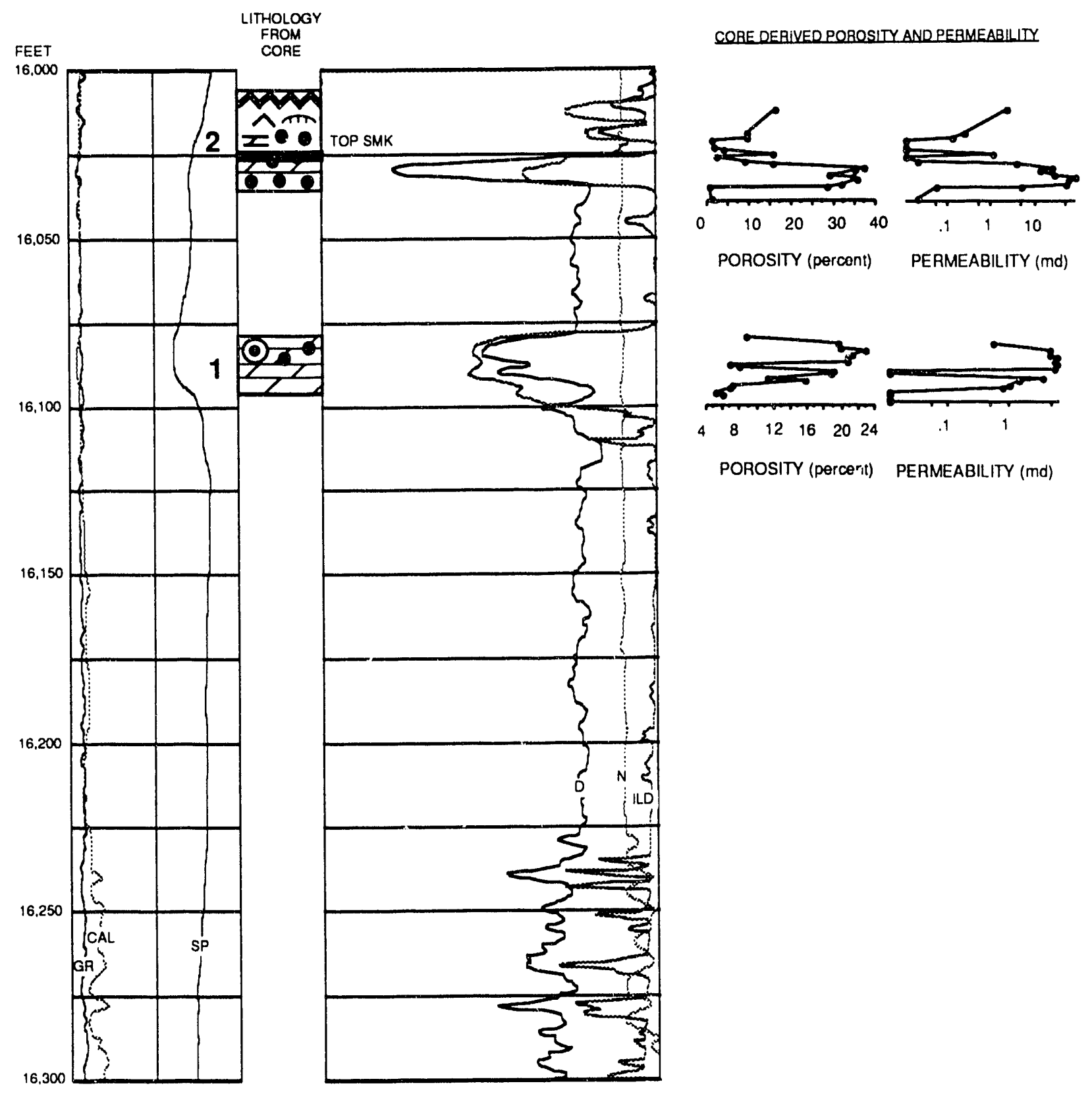

Figure CTM-3,--Well log correlated to lithology, porosity, and permeability, Chatom Unit 20-14 No. 1-04 well, Permit No. 7044, Chatom field, Alabama. 

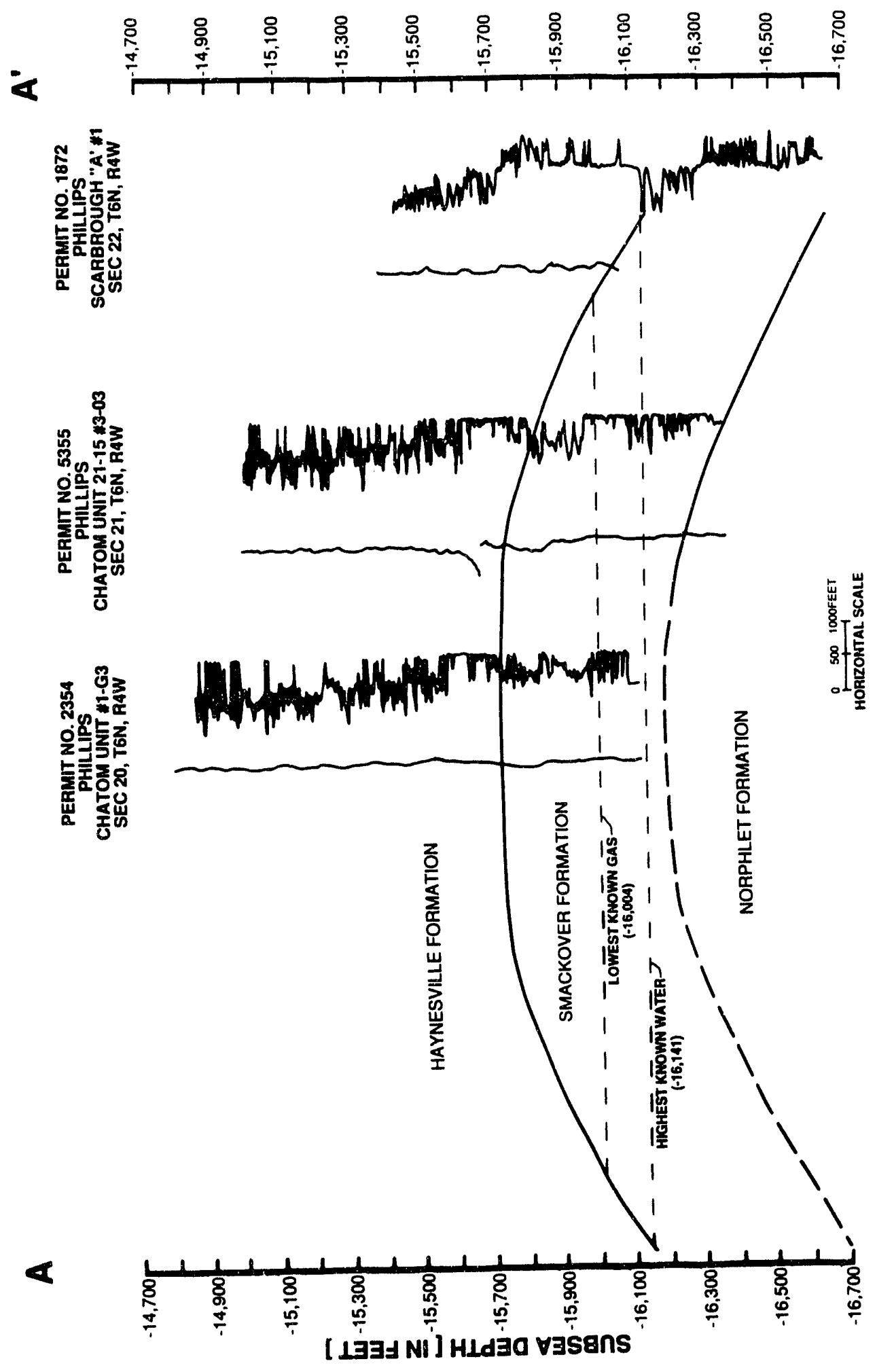

8̊

ह

옹

응

兴

든

온은

둥우

竎

哭

\&

今

妾

苋究

흐

ฐํํำ

范

ร

芹施

ธ్

喜要

कं क

हี

而

은

등

ธิ 을

흔

兄

ㅎํㅁ

호

造

号

잉

एँ

岂

के

.

过 

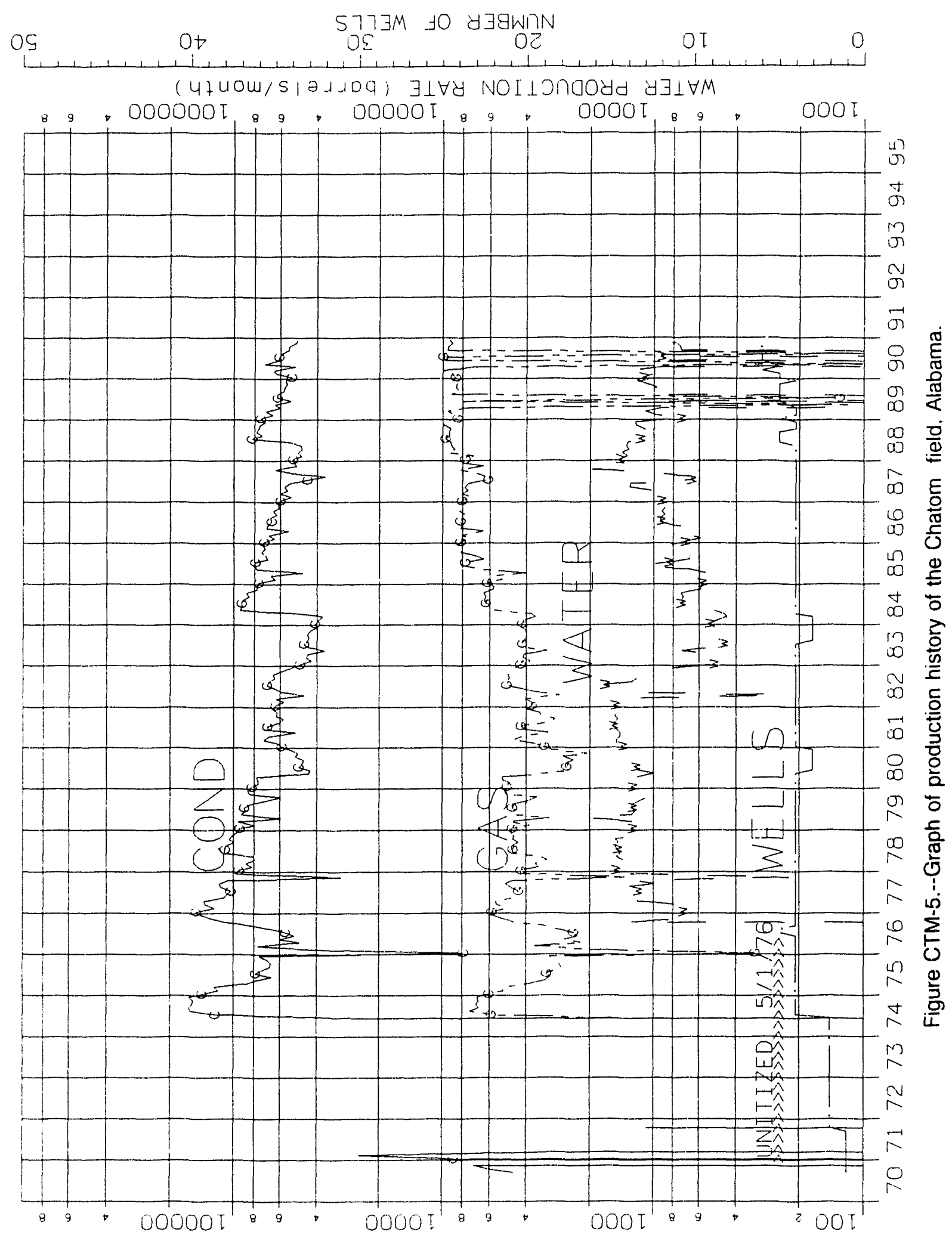

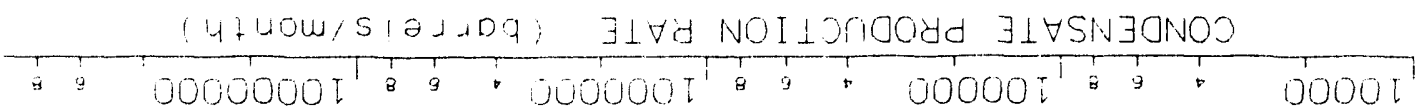

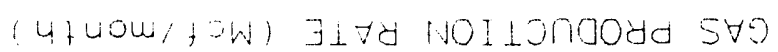


(a)

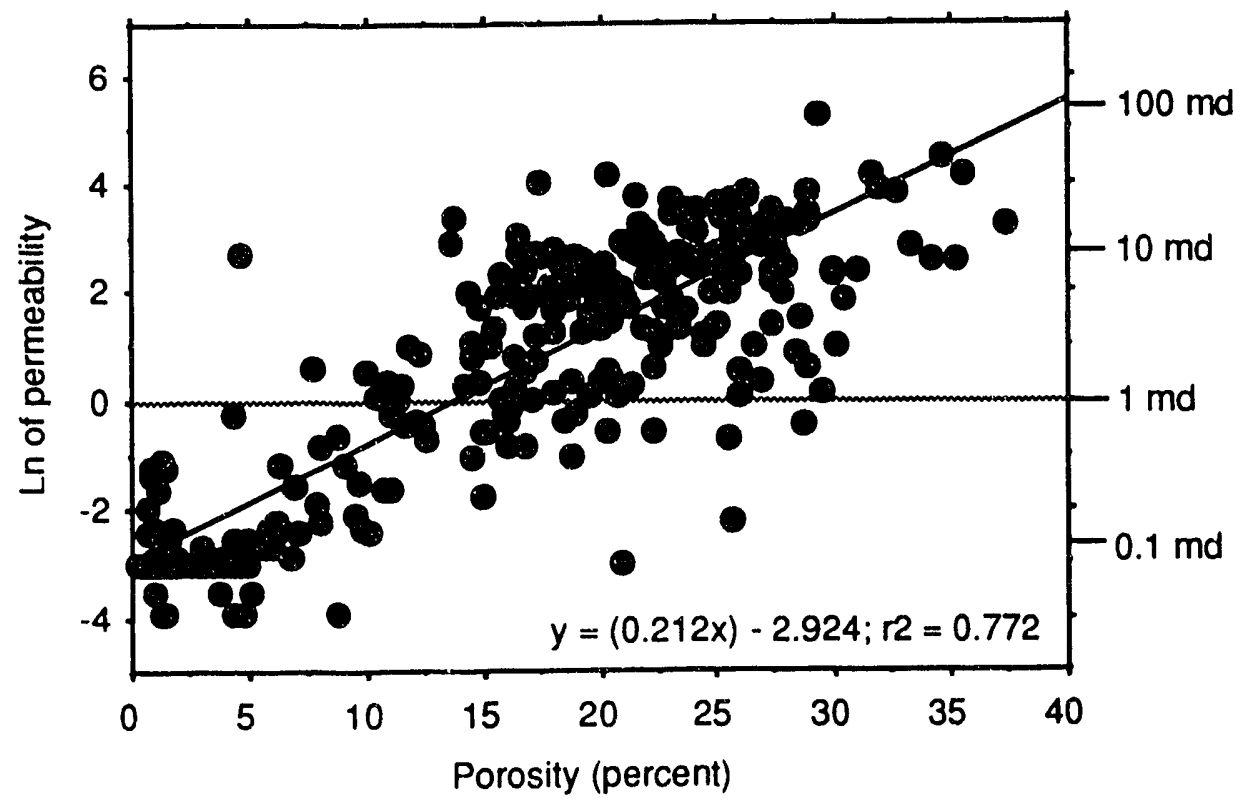

(b)

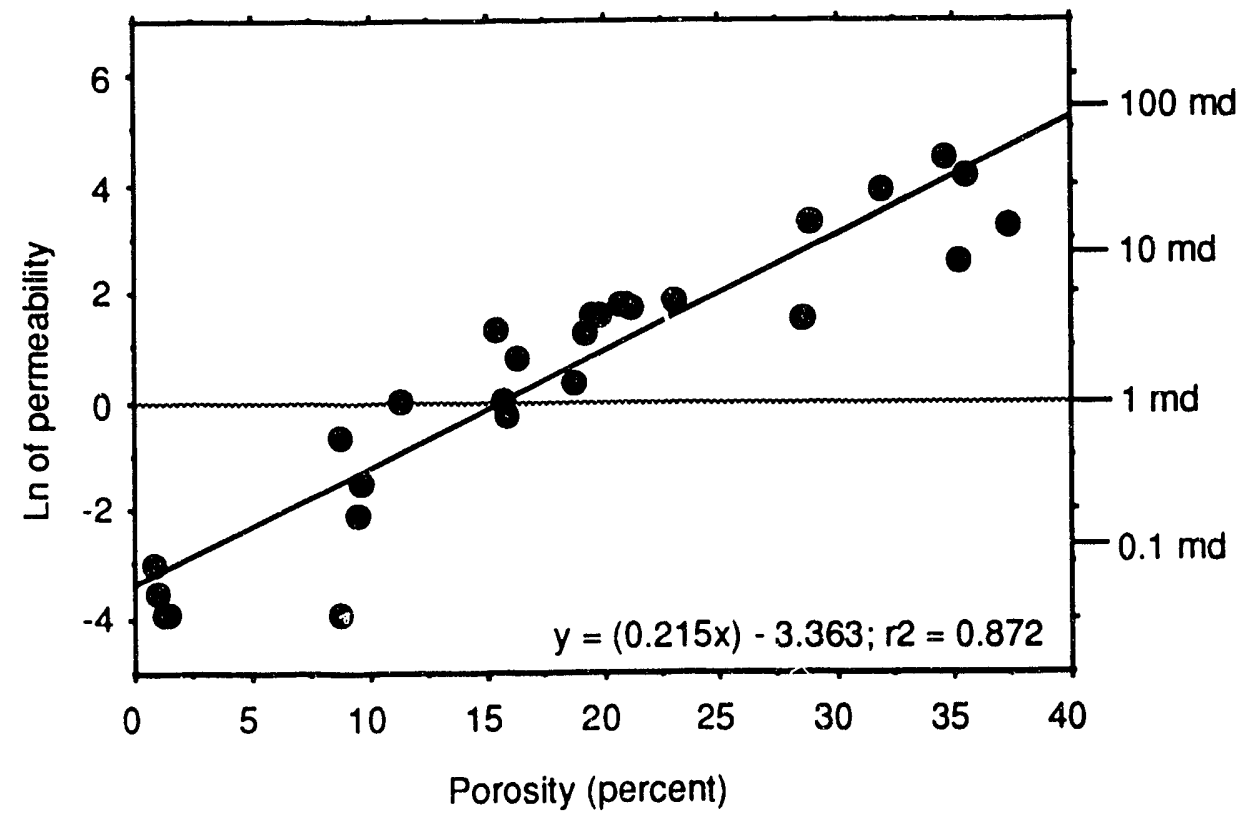

Figure CTM-6.--Porosity vs. natural log permeability plots, Chatom field, Alabama. (a) Plot of five cores combined, and (b) plot of described core for Chatom Unit 20-14 No. 1-04 well, Permit No. 7044. Equations apply to regression lines. 
Table CTM-1.--Reservoir characterization sheet, Smackover pool, Chatom field, Washington County, Alabama

\section{Discovery well}

Operator: Phillips Petroleum Co.

Permit number: 1543

Well Name: Williams "AA" \#1

Location: Sec. 20, T6N-R4W

Completion date: 08/12/70

Perforations: $15,999-16,114 \mathrm{ft}$

Initial flow rate: $988 \mathrm{bcpd}, 4,029 \mathrm{Mcfd}$,

$$
\text { 24/64 ck, 1,933 psi }
$$

\section{Field data (as of 12/31/90)}

Number of wells within field limits: 14

Producing wells in pool: 6

Production wells in field: 6

Shut-in/Temp. abandoned wells: 0

Plugged and abandoned wells: 3

Salt water disposal wells: 1

Enhanced recovery wells: 2

Dry holes: 2

Drilling wells: 0

Unit spacing (acres): Unitized

Total field area (acres): 7,680

Cumulative production

Condensate (bbl): 14,212,601

Gas (Mcf): 109,780,337

Water (bbl): 963,358

\section{Reservoir data}

Trap type: Structural

Reservoir structure: Anticline

Proven productive area (acres): 2,080

Average net pay thickness (feet): 56

Hydrocarbon type: Gas condensate

Oil gravity (API): 55

Initial reservoir pressure (psia): 7,903

Current reservoir pressure (psia): na

Reservoir drive: Depletion

Type of enhanced recovery: Gas injection

Mean porosity (core) (\%): 14.70

Porosity standard deviation (\%): 10.20

Maximum porosity (\%): 37.20

Minimum porosity (\%): 0.13

Number of porosity analyses: 331

Geometric mean perm (core) (md): 1.21

Maximum permeability (md): 196.00

Minimum permeability (md): 0.02

Number of permeability analyses: 331

Dykstra-Parsons coefficient: na 


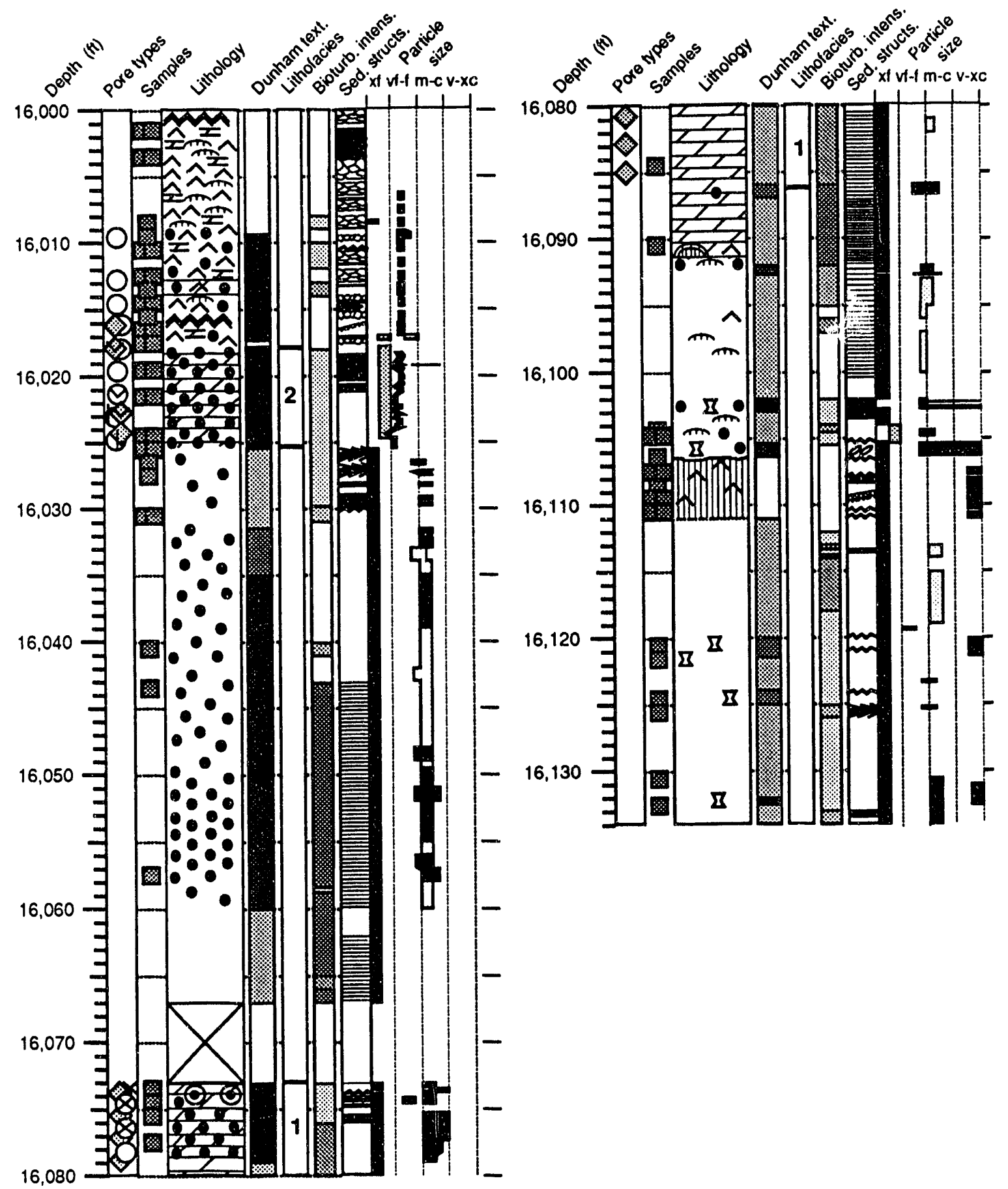

Figure CTM-7.--Detailed core log, Chatorn Unit 20-14 No. 1 1-04, Permit No. 7044, Chatom field, Alabama. 
Table CTM-2.--Lithofacies description of core from Chatom Unit 20-14 No. 1-04 well, Permit No. 7044, Chatom field, Alabama (see figure CTM-7)

Lithofacies 1: Pelmoldic and crystalline dolostone

Pore types:

Intercrystalline: $62 \%$

Moldic: $22 \%$

Secondary intraparticle: $16 \%$

Mean porosity (\%): 18.0

Maximum porosity (\%): 22.9

Minimum porosity $(\%): 8.7$

Porosity standard deviation (\%): 4.4

Number of analyses: 11

Geometric mean permeability (md): 2.83

Maximum permeability (md): 6.58

Minimum permeability (md): 0.55

Number of analyses: 11

Depositional environment: Shallowing upward shallow subtidal lagoon to ooid shoal.

Diagenesis: Dolomitization and leaching, porosity occlusion by anhydrite and calcite cements.

Percent of resenoir: 62

Depth interval(s) (ft): $16,073-16,086$

Lithofacies 2: Pellet dolograinstone

Pore types:

Moldic: $90 \%$

Intercrystalline: $10 \%$

Mean porosity (\%): 28.4

Maximum porosity (\%): 37.2

Minimum porosity (\%): 8.7

Porosity standard deviation (\%): 10.6

Number of analyses: 8

Geometric mean permeability (md): 11.13

Maximum permeability (md): 88.00

Minimum permeability (md): 0.02

Number of analyses: 8 
Table CTM-2.--Lithofacies description of core from Chatom Unit 20-14 No. 1-04 well, Permit No. 7044, Chatom field, Alabama (see figure CTM-7) -. Continued

Depositional environment: Microtidal flat.

Diagenesis: Dolomitization and leaching.

Percent of reservoir: 38

Depth interval(s) (ft): $16,018-16,025.5$ 
(a)

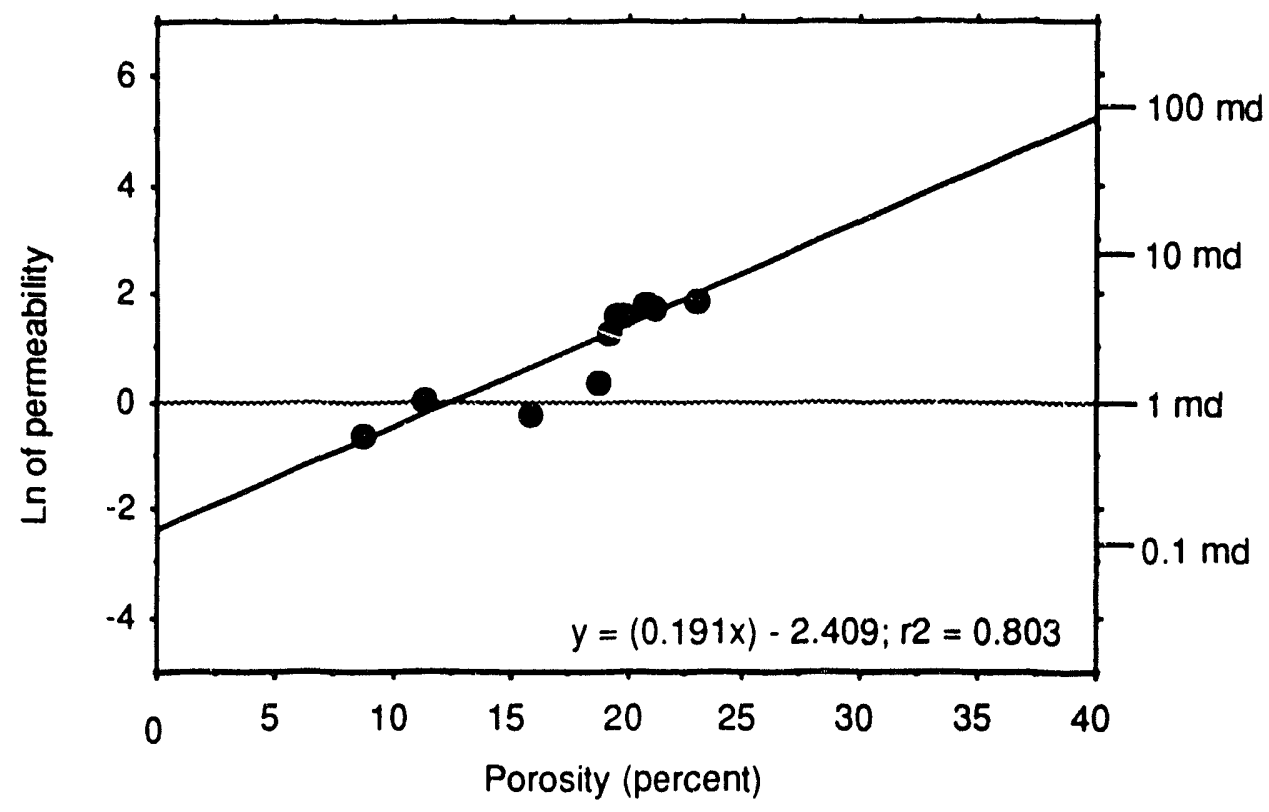

(b)

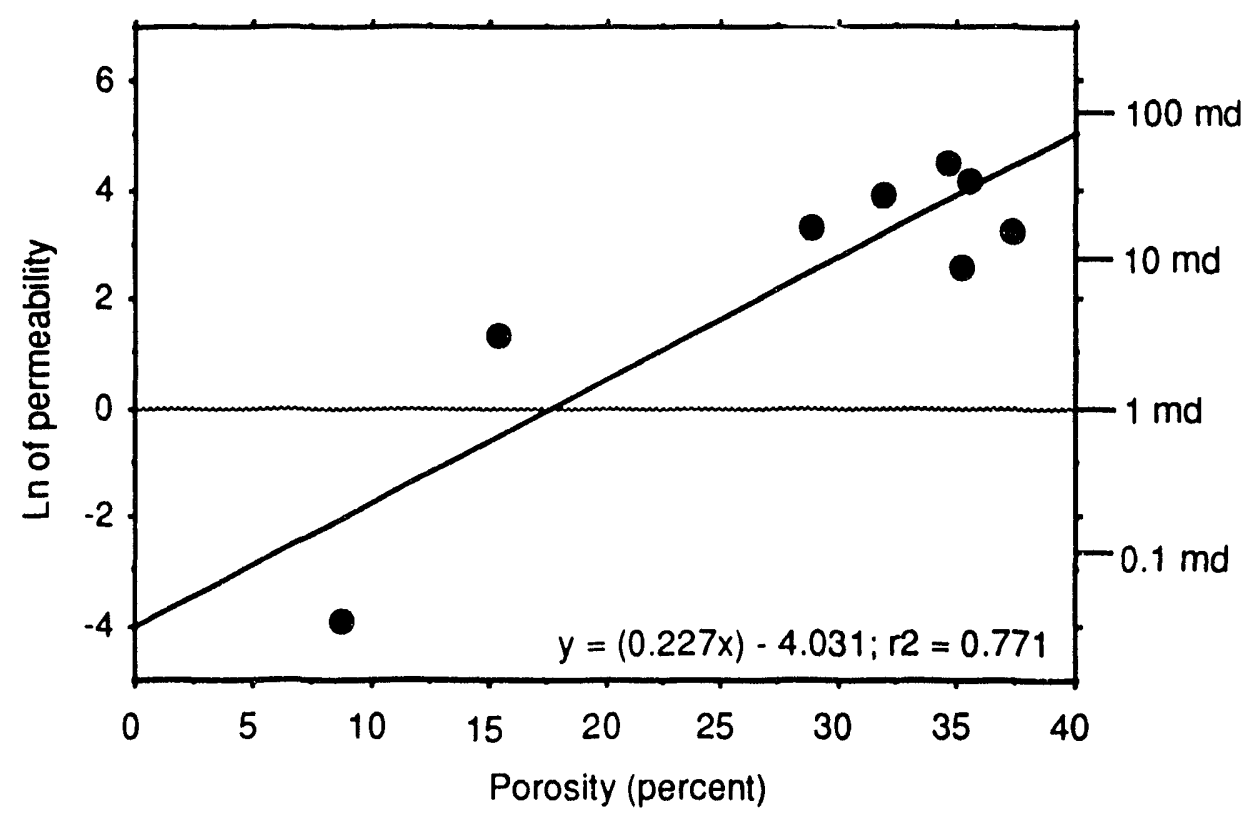

Figure CTM-8.--Porosity vs. natural log permeability plots for two lithofacies, Chatom Unit 20-14 No. 1 04 well, Permit No. 7044, Chatom field, Alabama. (a) Lithofacies 1, and (b) lithofacies 2. Equations for regression lines are printed for each lithofacies. (See table CTM-2 for descriptions of lithofacies.) Data set excludes all samples with porosity values and permeability values below reservoir cutoffs at $6 \%$ and $0.1 \mathrm{md}$, respectively. 


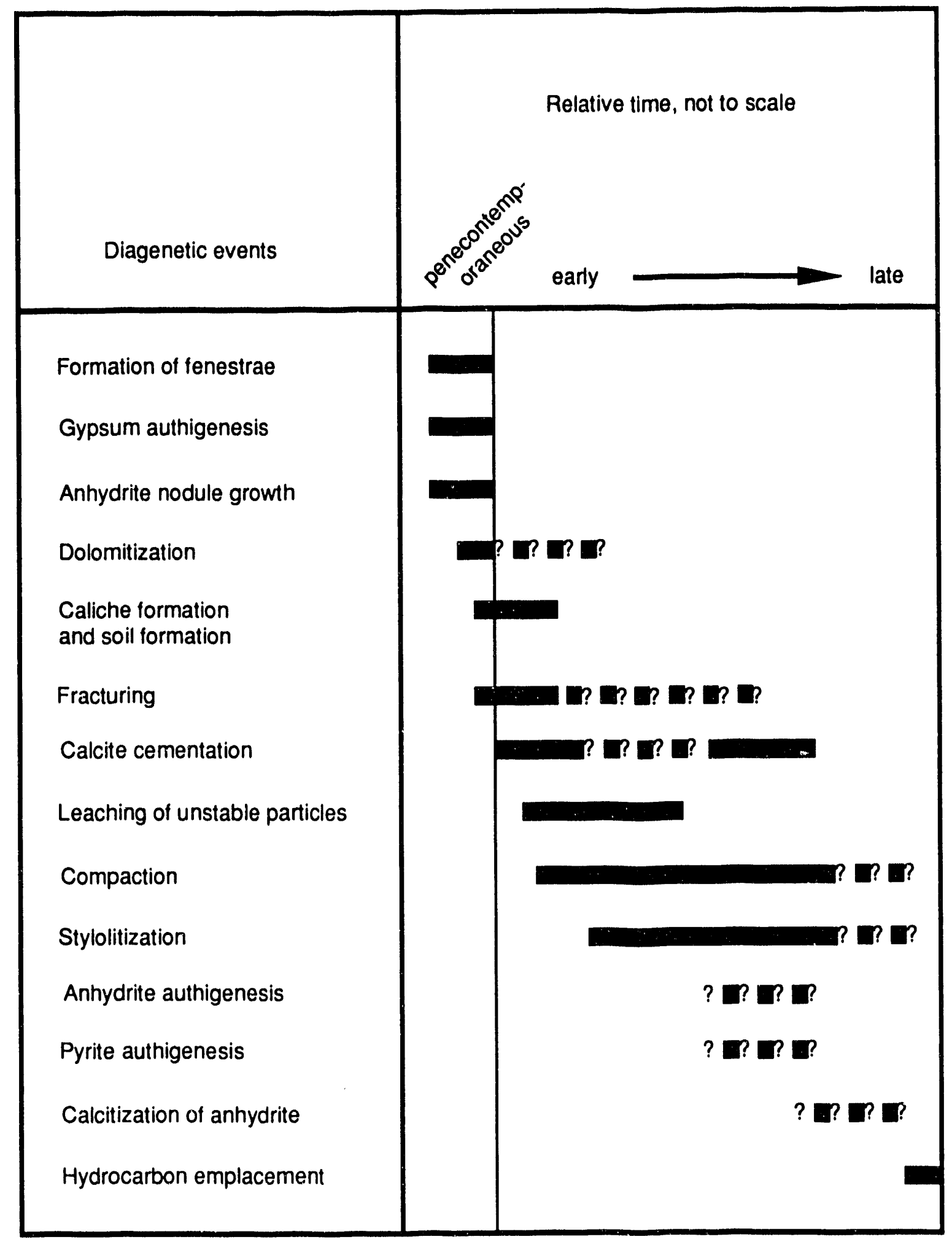

Figure CTM-9.--Paragenetic sequence, Chatom Unit 20-14 No. 1-04 well, Permit No. 7044, Chatom field, Alabama. 


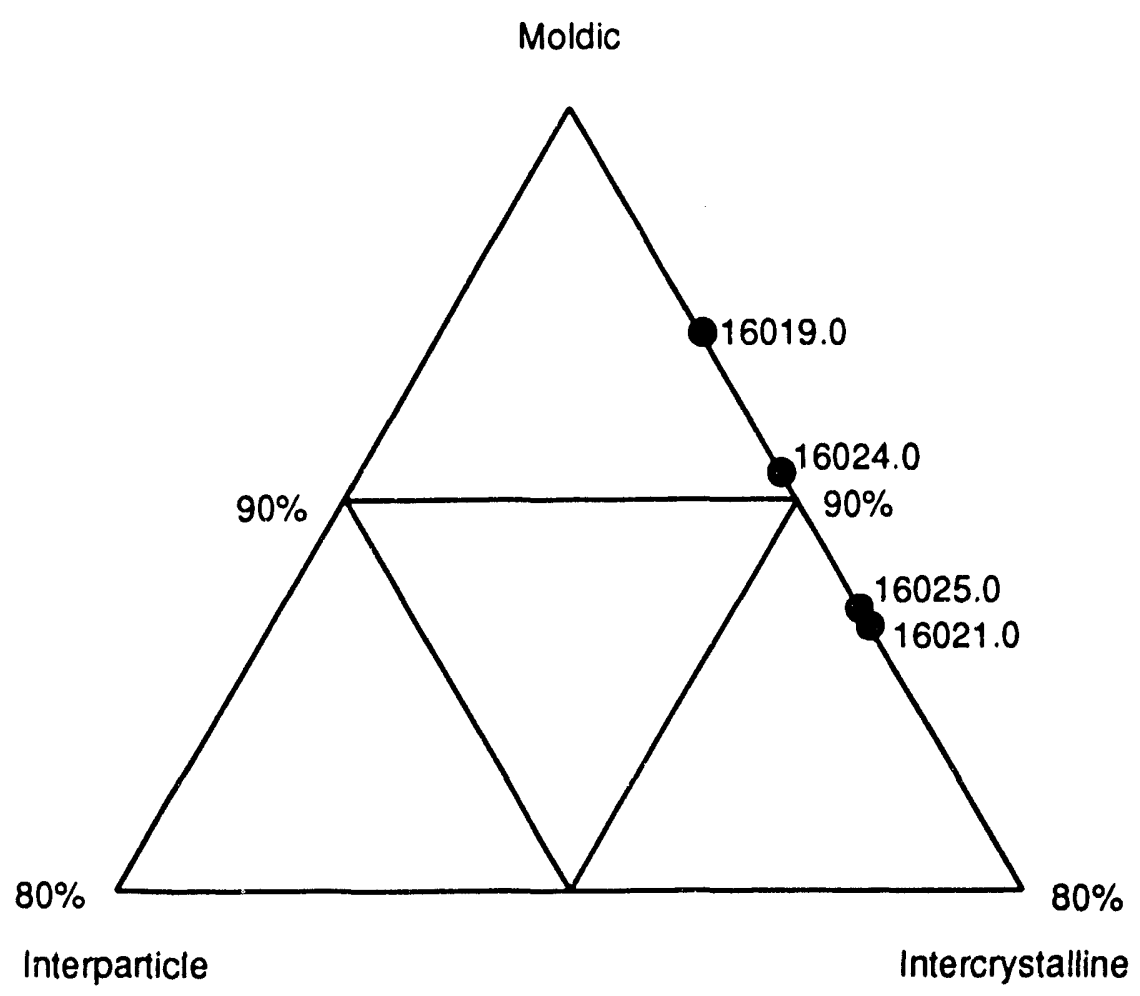

Figure CTM-10.--Ternary diagram of pore types, Chatom Unit 20-14 No. 1-04 well, Permit No. 7044, Chatom field, Alabama. Percentages of moldic pores indicated. Sample depths are indicated to nearest 0.1 foot. 
CHOCTAW RIDGE FIELD

\section{SMACKOVER OIL POOL}

CHOCTAW COUNTY, ALABAMA 


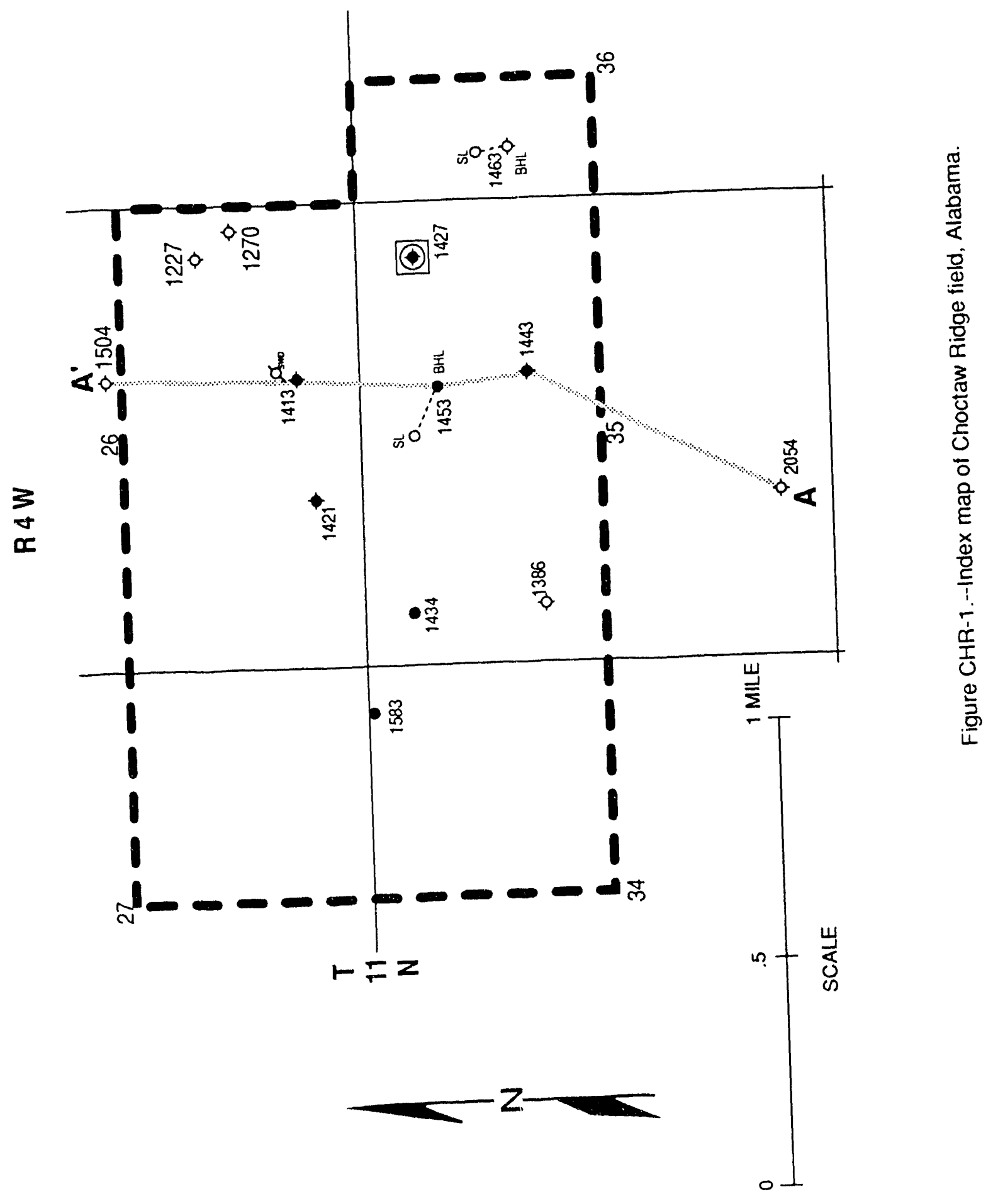




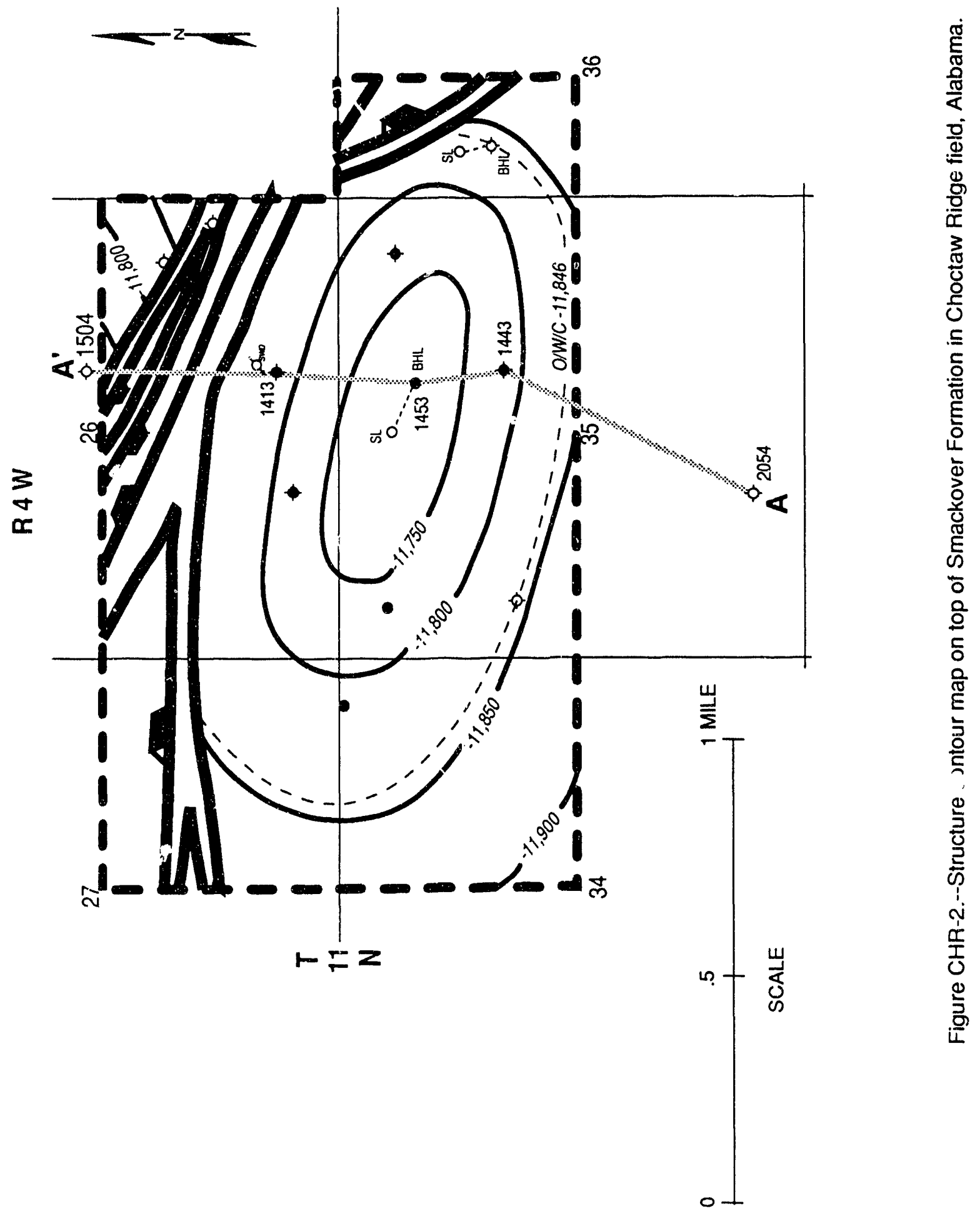




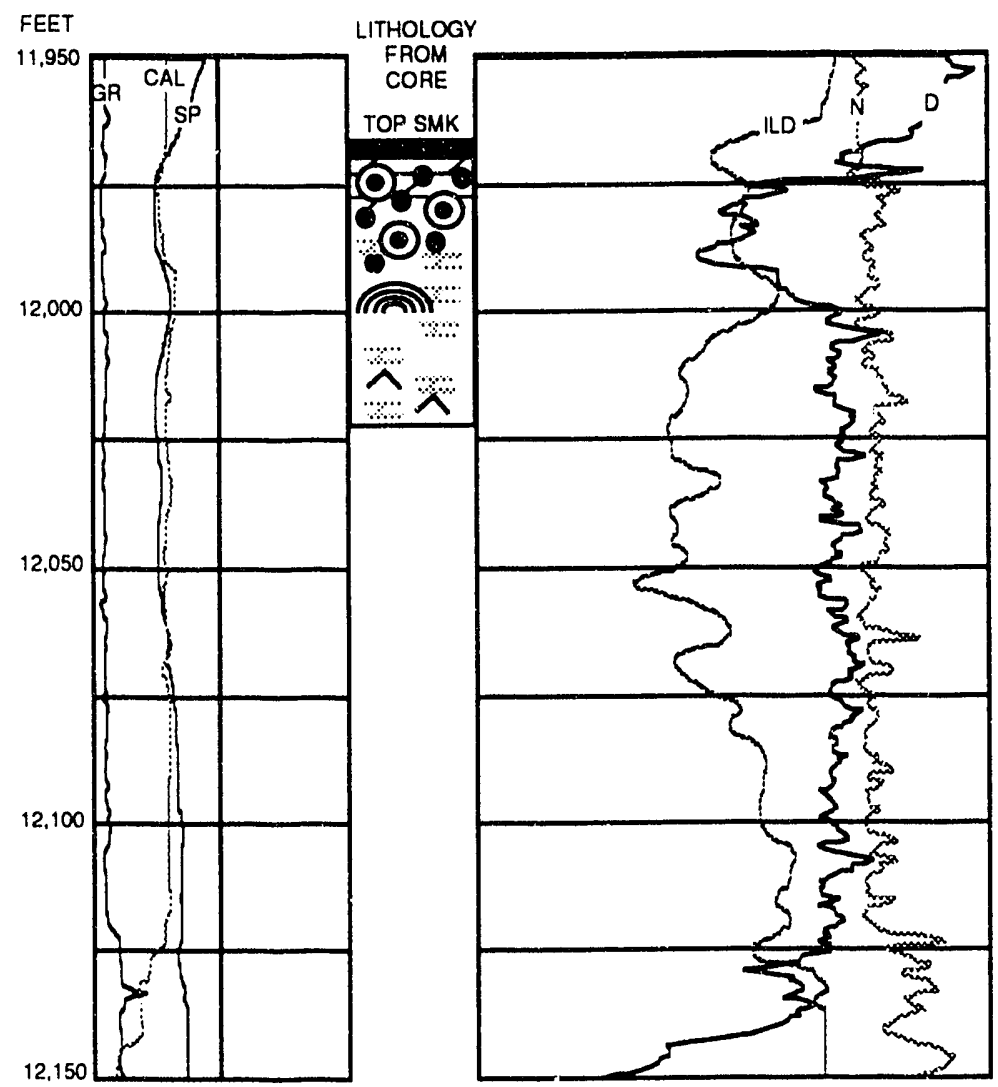

Figure CHR-3.--Well log correlated to lithology, Rentz-Trice Unit 35-1 well, Permit No. 1427, Choctaw Ridge field, Alabama. 


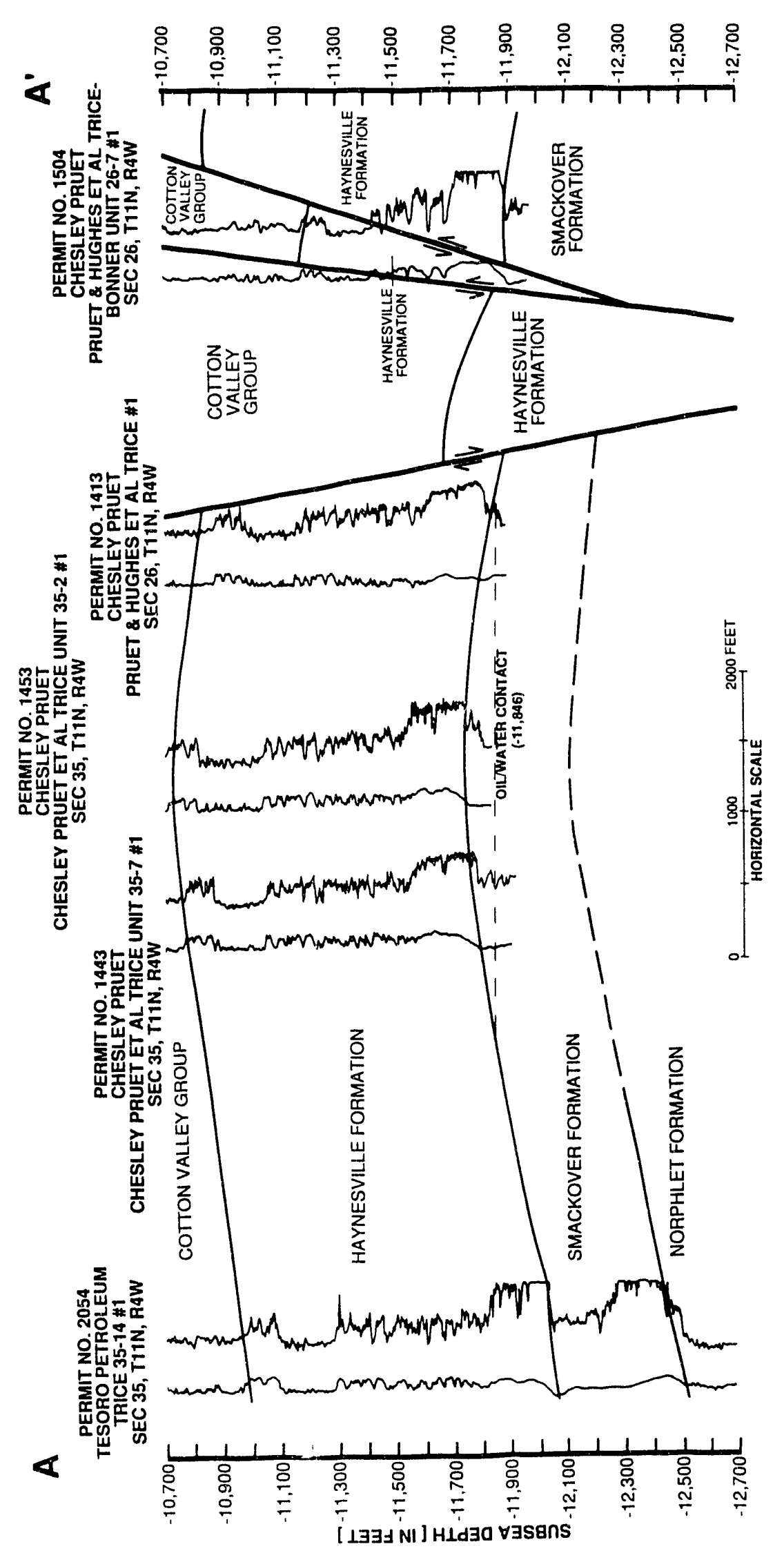

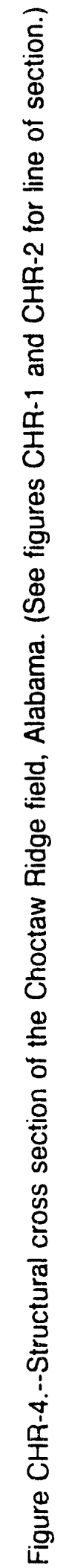




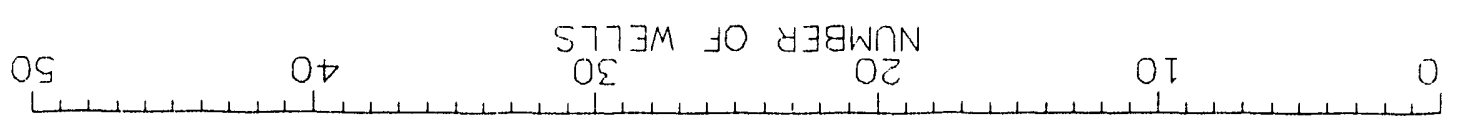

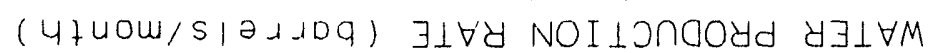
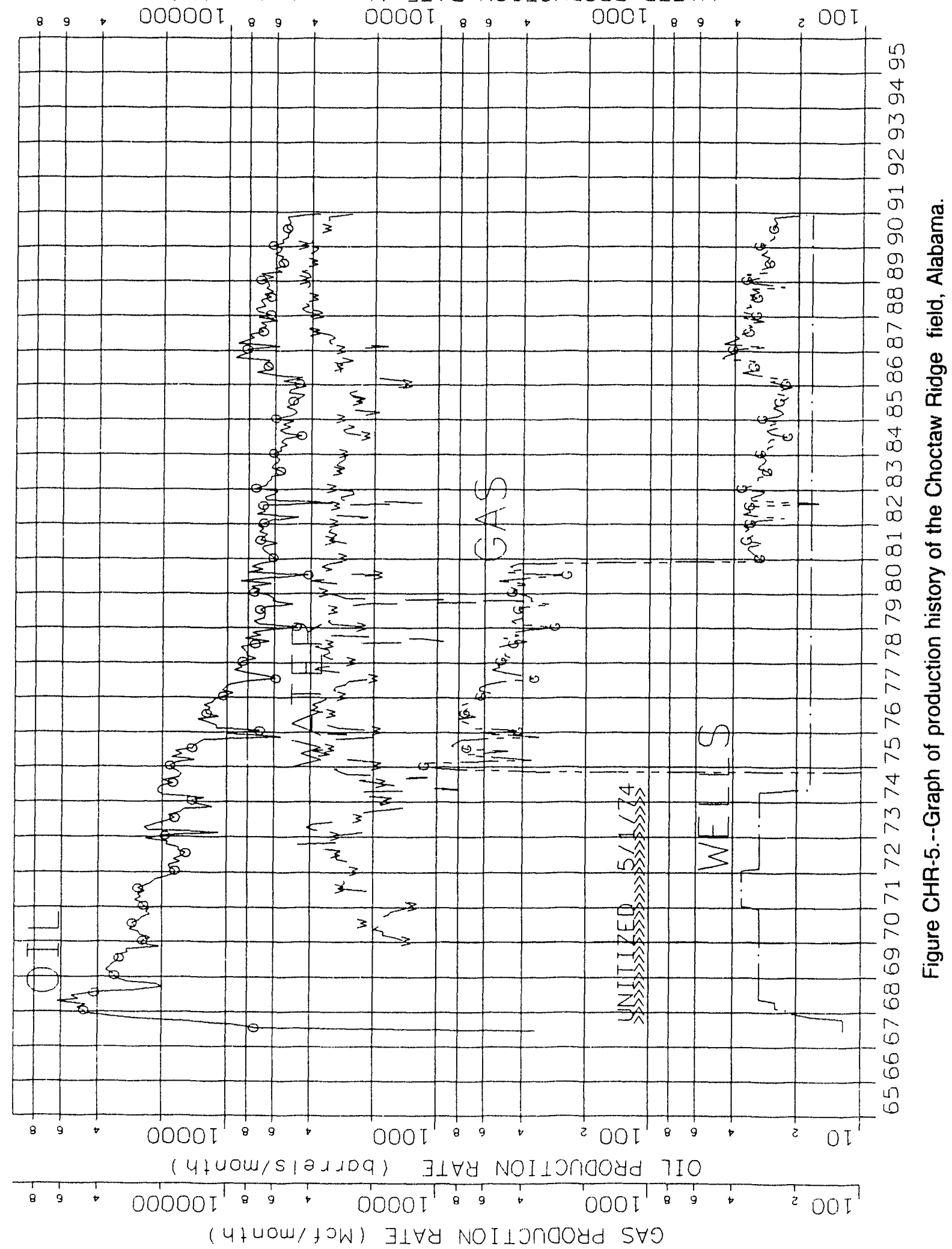


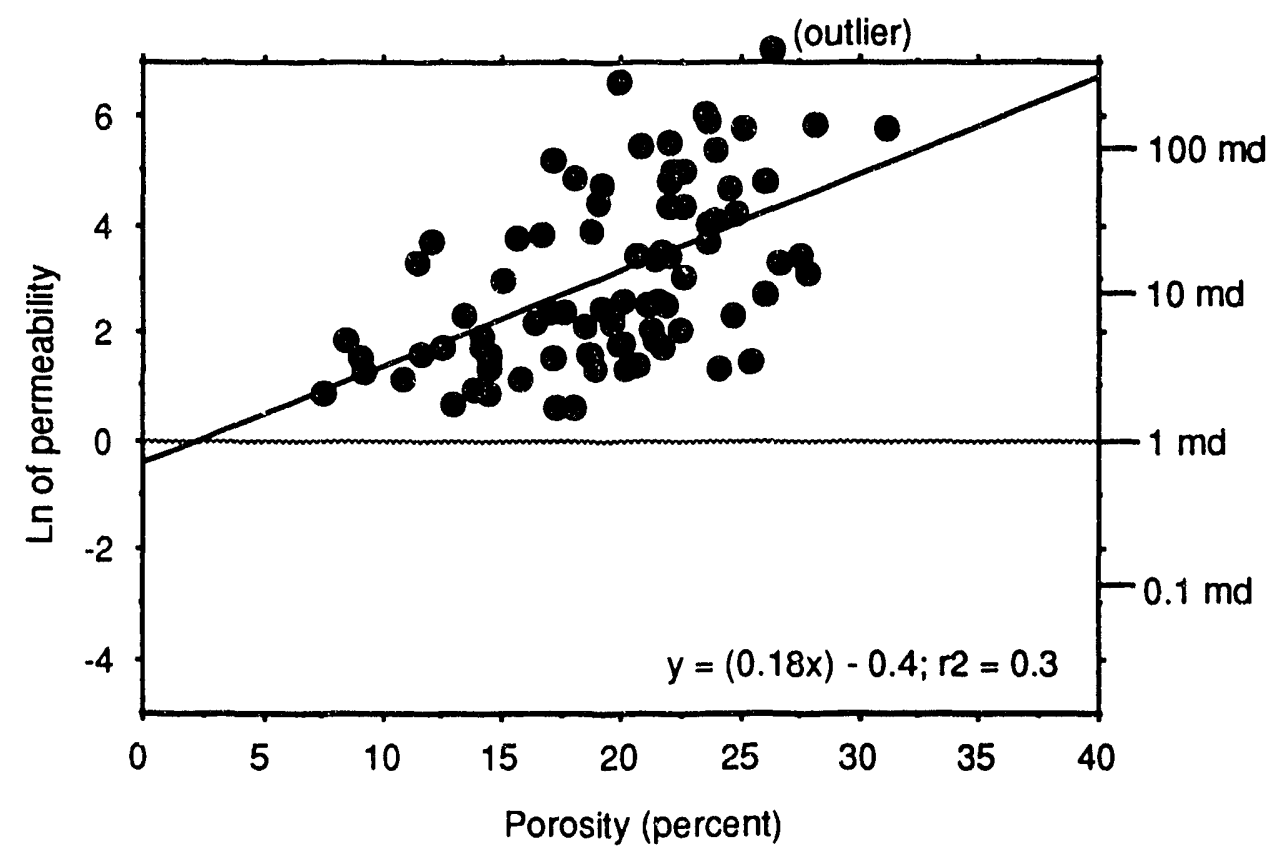

Figure CHR-6.--Porosity vs. natural log permeability plot of five cores combined, Choctaw Ridge field, Alabama. Equation applies to regression line. 
Table CHR-1.--Reservoir characterization sheet, Smackover pool, Choctaw Ridge field, Choctaw County, Alabama

\section{Discovery well}

Operator: Pruet \& Hughes Co.

Permit number: 1413

Well Name: Trice \#1

Location: Sec. 26, T11N-R4W

Completion date: 06/19/67

Perforations: $11,940-11,952,11,963-11,964 \mathrm{ft}$

Initial flow rate: 840 bopd, 558 Mcfd,

$$
1 / 4 \mathrm{ck}, 1,500 \mathrm{psi}
$$

\section{Field data (as of $12 / 31 / 90$ )}

Number of wells within field limits: 12

Producing wells in pool: 3

Production wells in field: 3

Shut-in/Temp. abandoned wells: 0

Plugged and abandoned wells: 5

Salt water disposal wells: 1

Enhanced recovery wells: 0

Dry holes: 3

Drilling wells: 0

Unit spacing (acres): Unitized

Total field area (acres): 1,040

Cumulative production

Oil (bbl): $3,608,435$

Gas (MCf): $1,853,154$

Water (bbl): 74,593

\section{Reservoir data}

Trap type: Structural

Reservoir structure: Faulted anticline

Proven productive area (acres): 549

Average net pay thickness (feet): 22

Hydrocarbon type: Oil

Oil gravity (API): 41

Initial reservoir pressure (psia): 5,650

Current reservoir pressure (psia): na

Reservoir drive: Solution gas / water

Type of enhanced recovery: none

Mean porosity (core) (\%): 19.39

Porosity standard deviation (\%): 4.95

Maximum porosity (\%): 31.10

Ninimum porosity (\%): 7.50

Numisei úi púrosity analyses: 87

Geometric mean perm (core) (md): 21.44

Maximum permeability (md): 1410.00

Minimum permeability (md): 1.90

Number of permeability analyses: 87

Dykstra-Parsons coefficient: na 


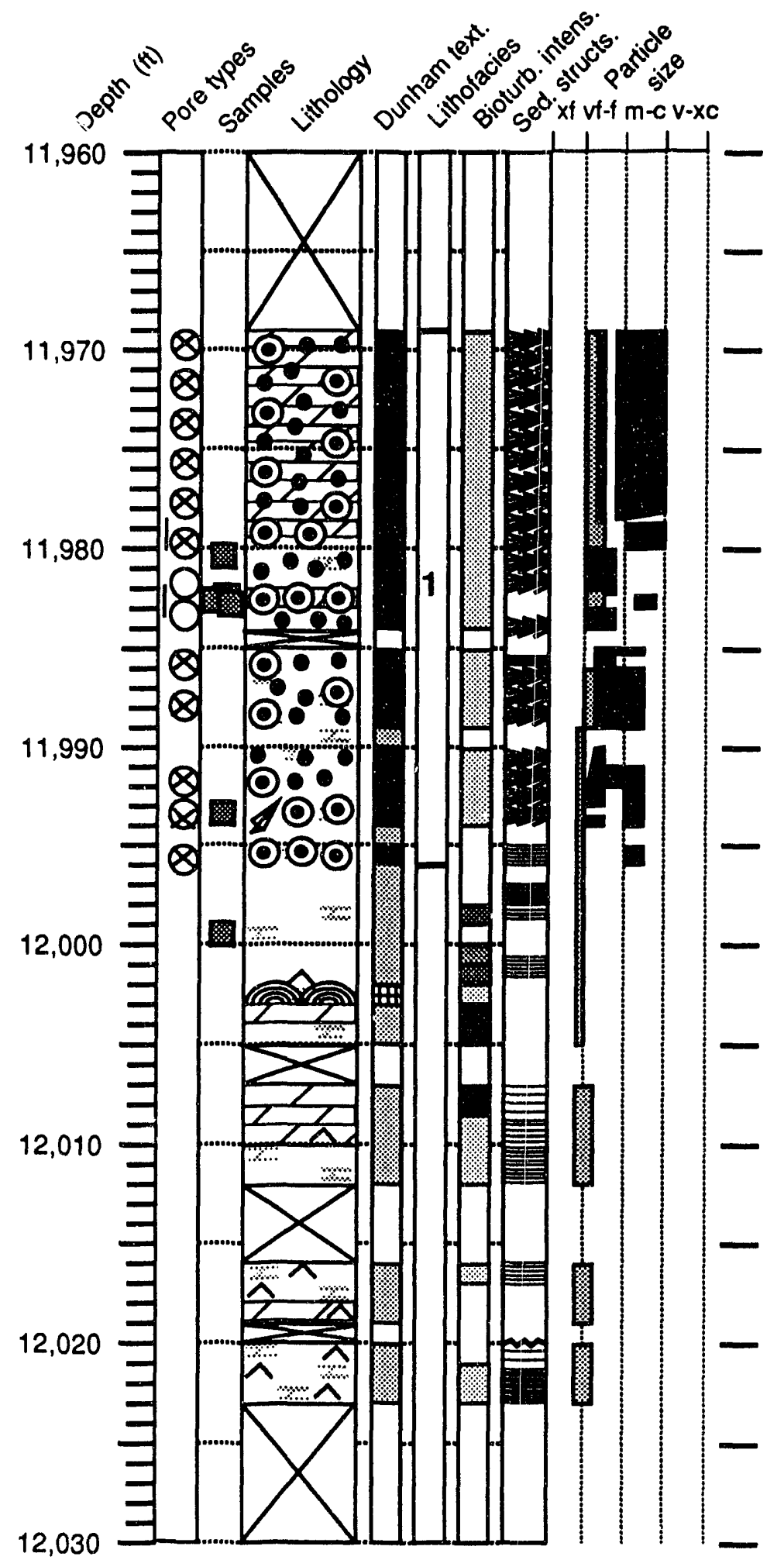

Figure CHR-7.--Detailed core log, Rentz-Trice Unit 35-1 well, Permit No. 1427, Choctaw Ridge field, Alabama. 
Table CHR-2.--Lithofacies description of core from Rentz-Trice Unit 35-1 No. 5 well, Permit No. 1427, Choctaw Ridge field, Alabama (see figure CHR-7)

Lithofacies 1: Oolitic and pelletal dolomitic grainstone and dolograinstone

Pore types:

Moldic: $61 \%$

Secondary Intraparticle: $36 \%$

Interparticle: $3 \%$

Depositional Environment: High-energy subtidal shoal.

Diagenesis: Minor penecontemporaneous gypsum formation was followed by interparticle calciumcarbonate cementation. Next, partial fabric-selective dolomitization and particle dissolution created the secondary pore system that dominates the reservoir. Several episodes of fracturing enhanced reservoir permeability. Stylolitization, anhydrite replacement and cementation, and dedolomitization also affected the reservoir.

Percent of reservoir: 100

Depth interval(s) (ft): $11,969-11,996$ 


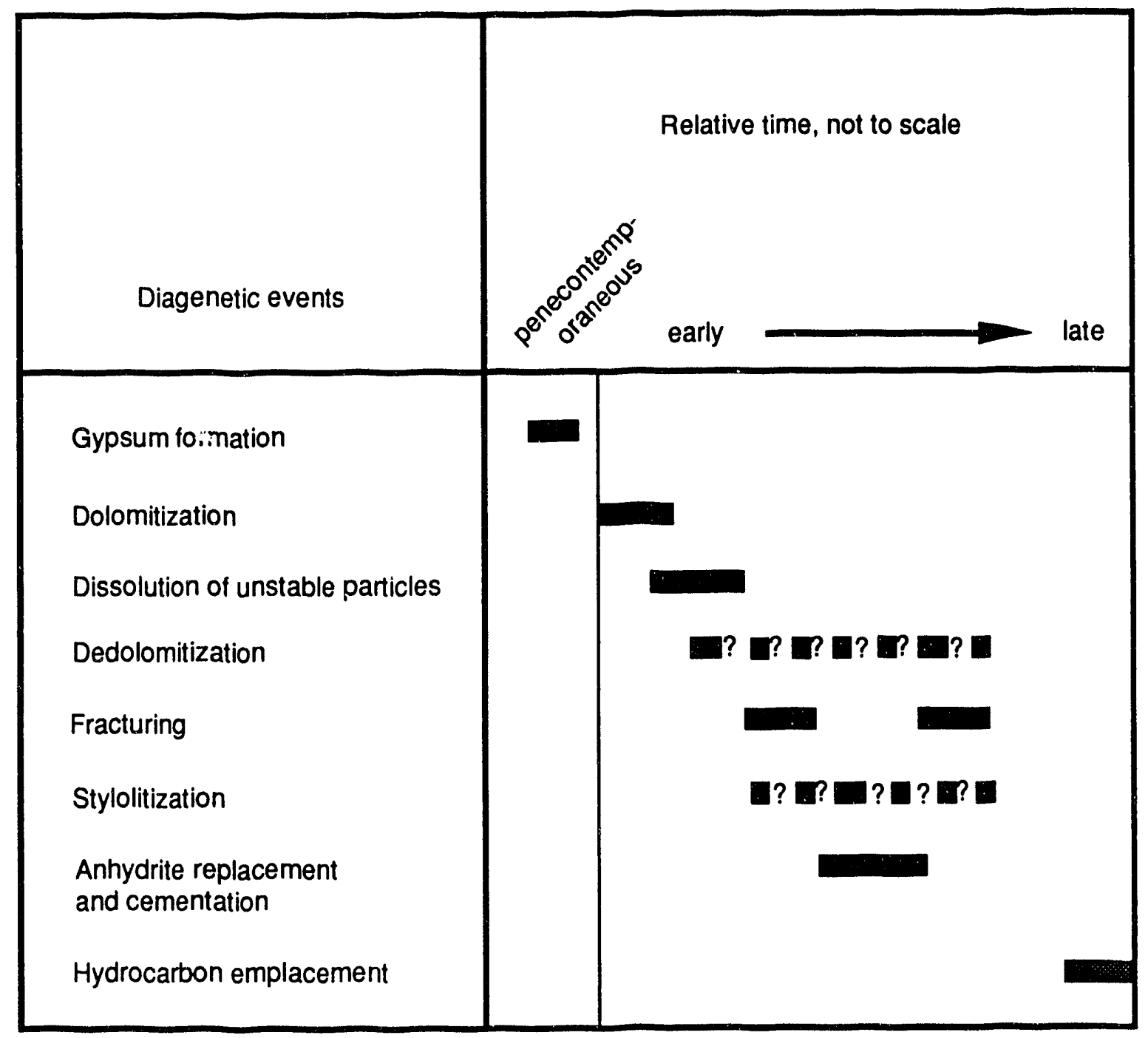

Figure CHR-8.--Paragenetic sequence, Rentz-Trice Unit 35-1 No. 1 well, Permit No. 1427, Choctaw Ridge field, Alabama. 
CHUNCHULA FIELD

\section{SMACKOVER GAS AND CONDENSATE POOL MOBILE COUNTY, ALABAMA}




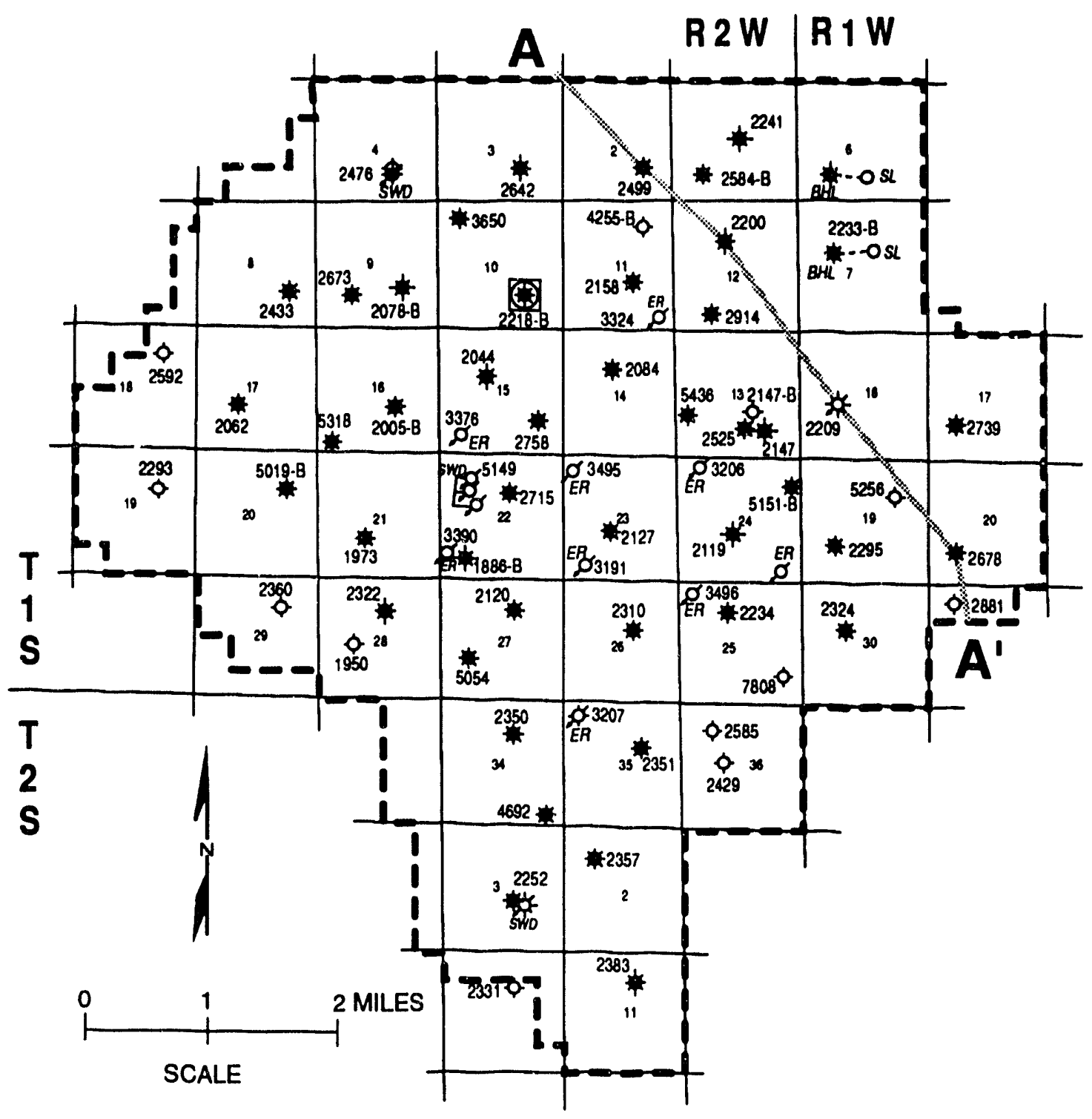

Figure CHU-1.--Index map of Chunchula field, Alabama. 


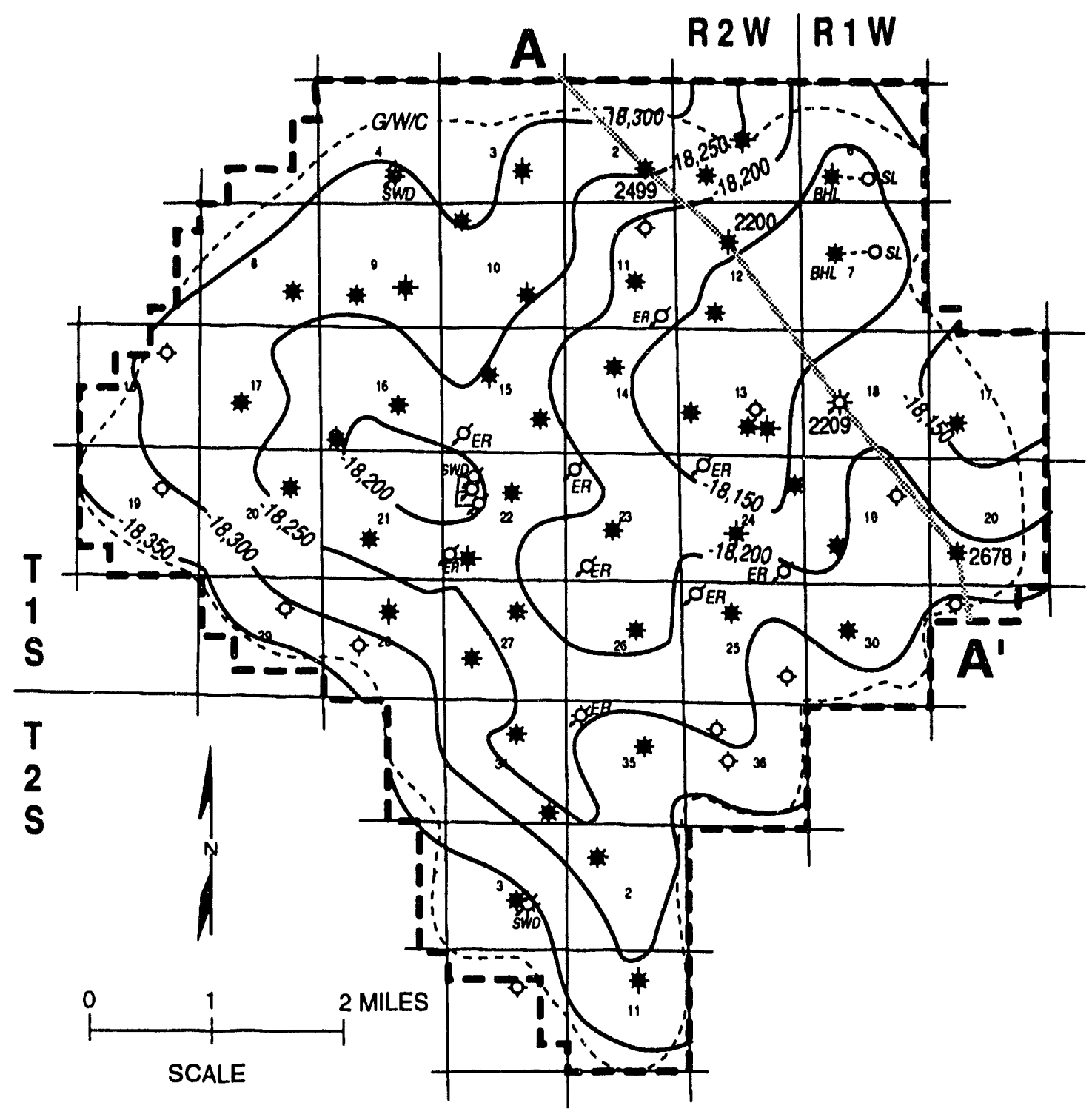

Figure CHU-2.--Structure contour map on top of Smackover Formation in Chunchula field, Alabama. 


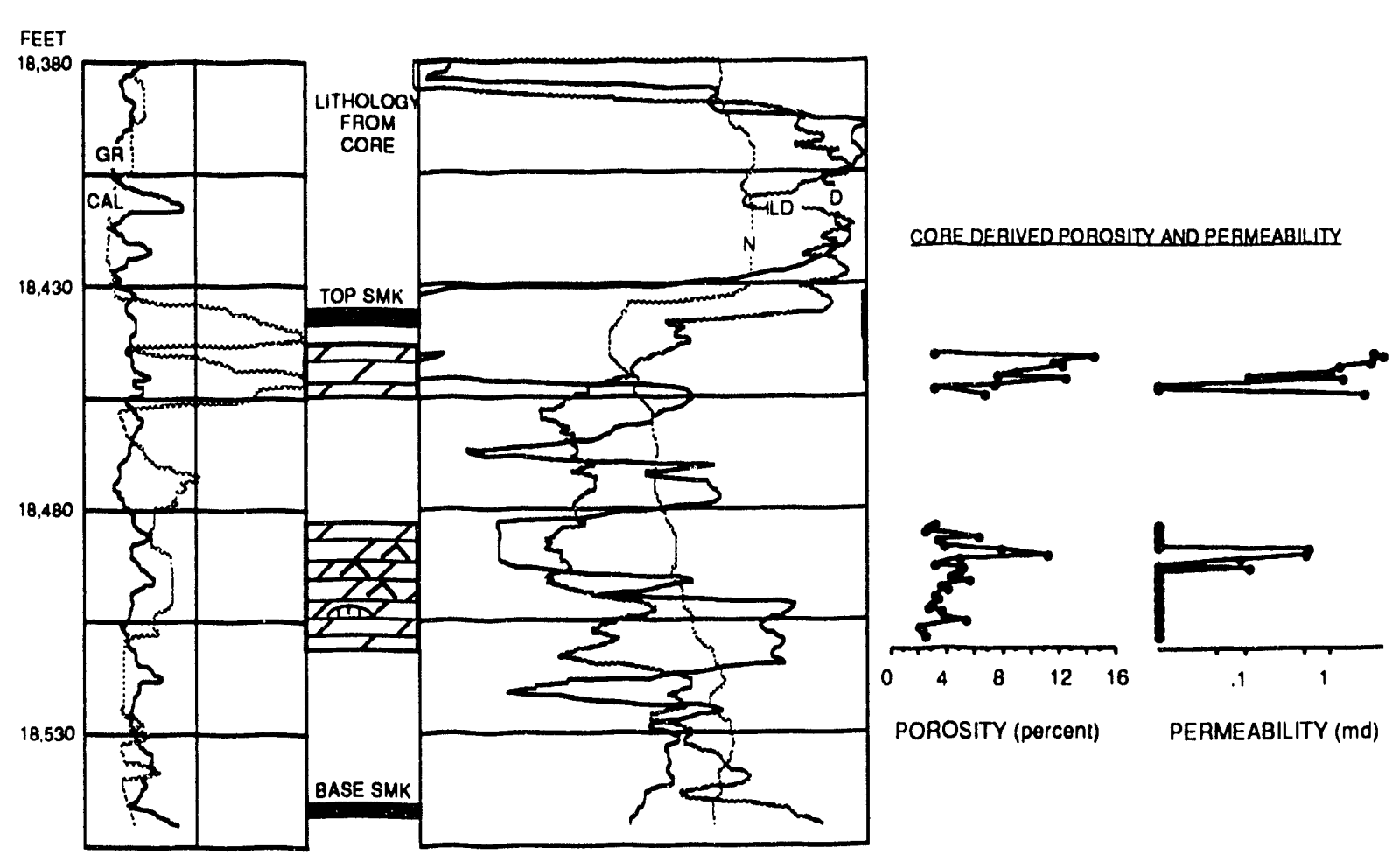

Figure CHU-3.--Well log correlated to lithology, porosity, and permeability, Annie M. Hill et al. 10-10 No. 1 well, Permit No. 2218, Chunchula field, Alabama. 


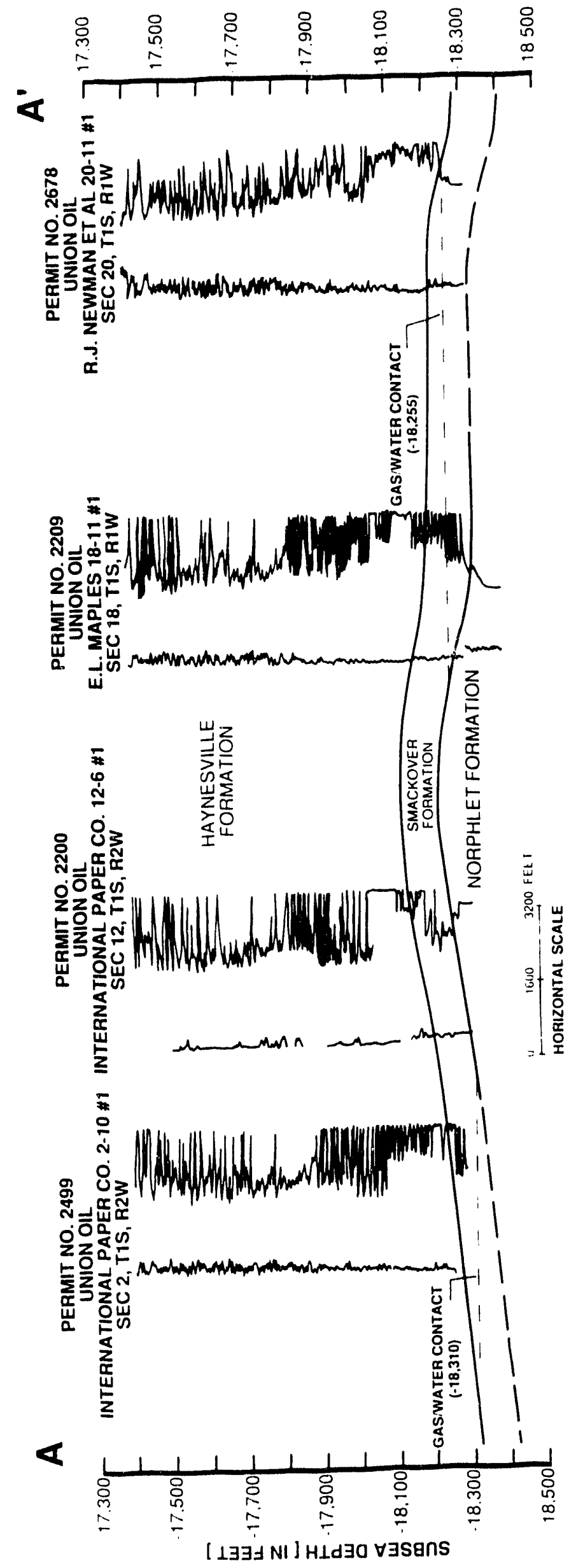



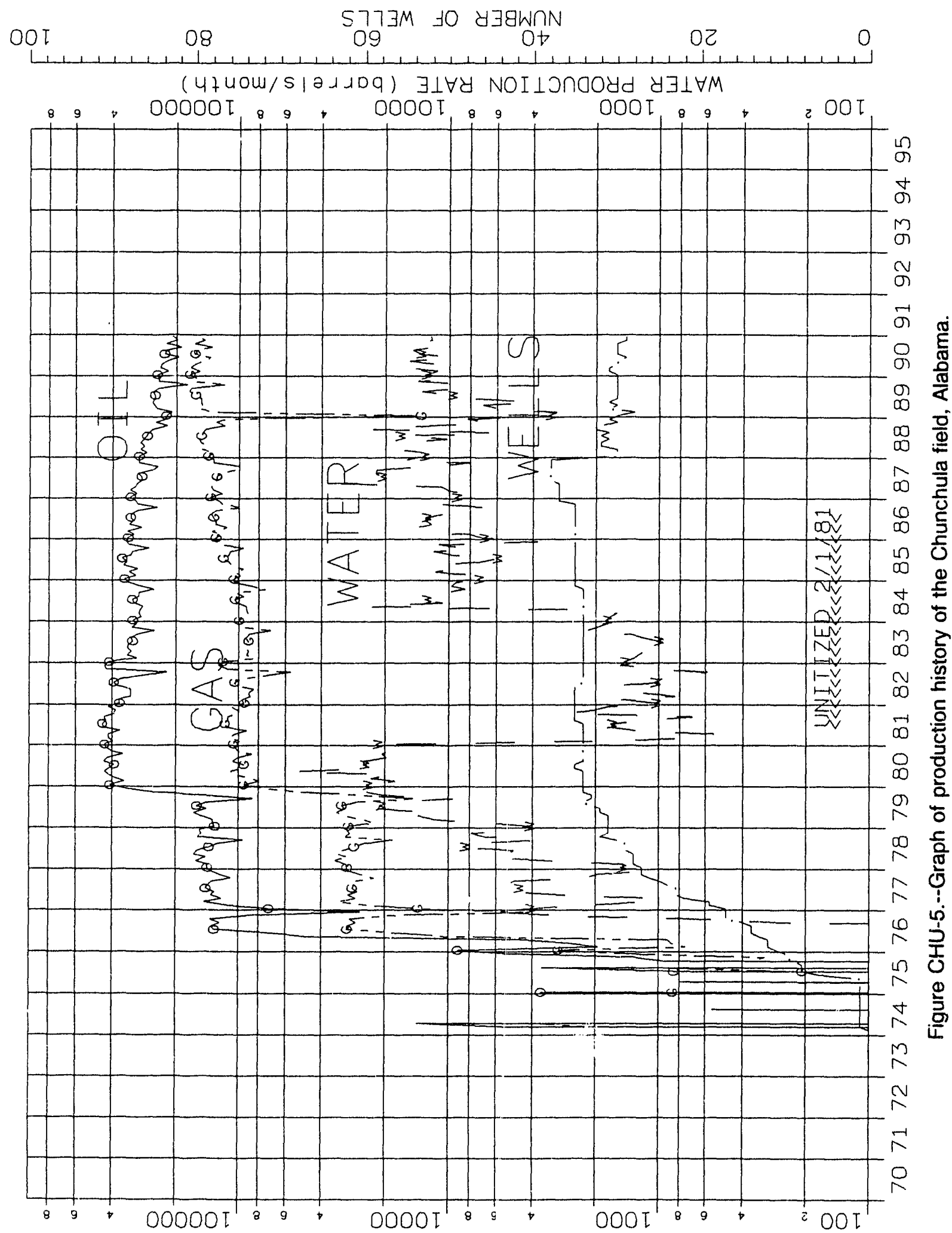

\footnotetext{
( $4+$ uow/S $\mid \partial \lambda \lambda D q) \quad \exists \perp \forall y$ NOI $\perp$ OnoOyd $7 I O$

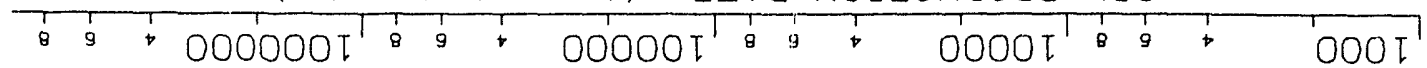

(4tuow/fOW) $\exists \perp \forall y$ NOI IOnOOUd SHO SMJ
} 
(a)

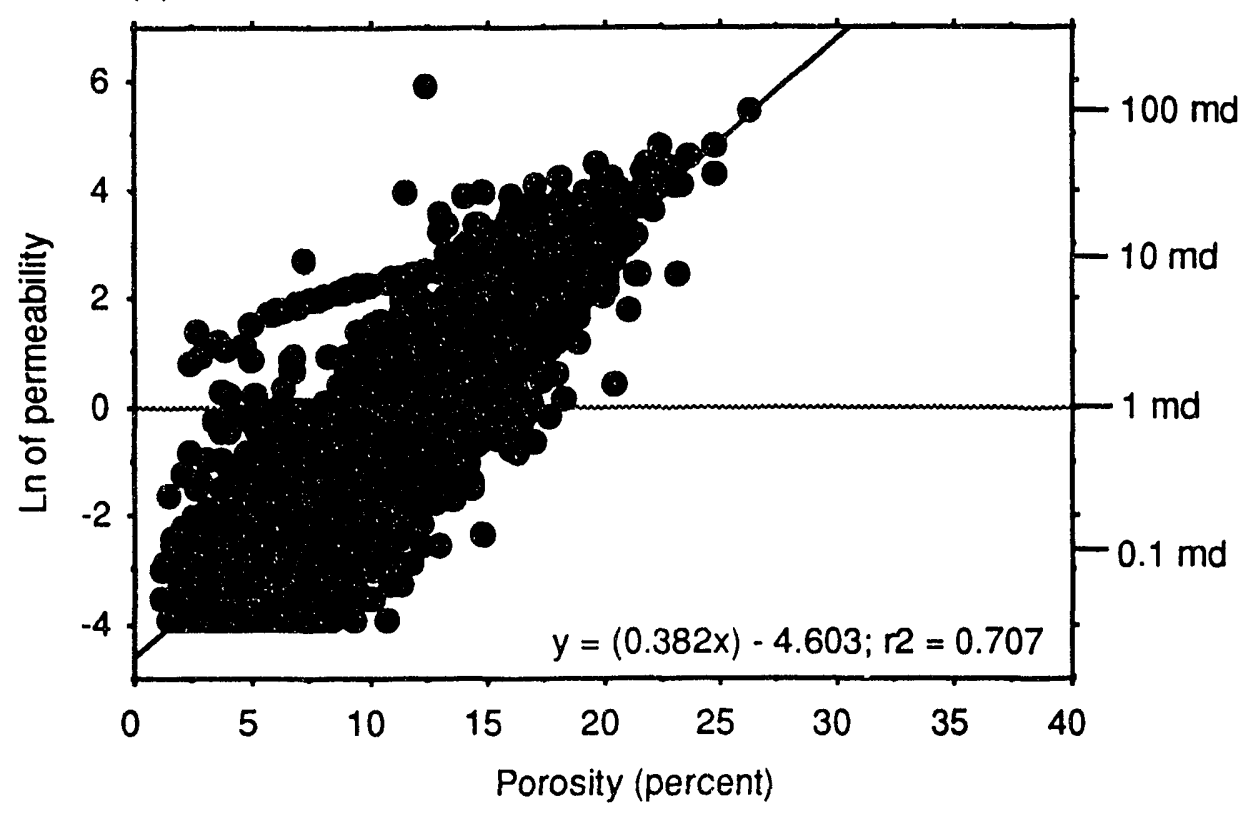

(b)

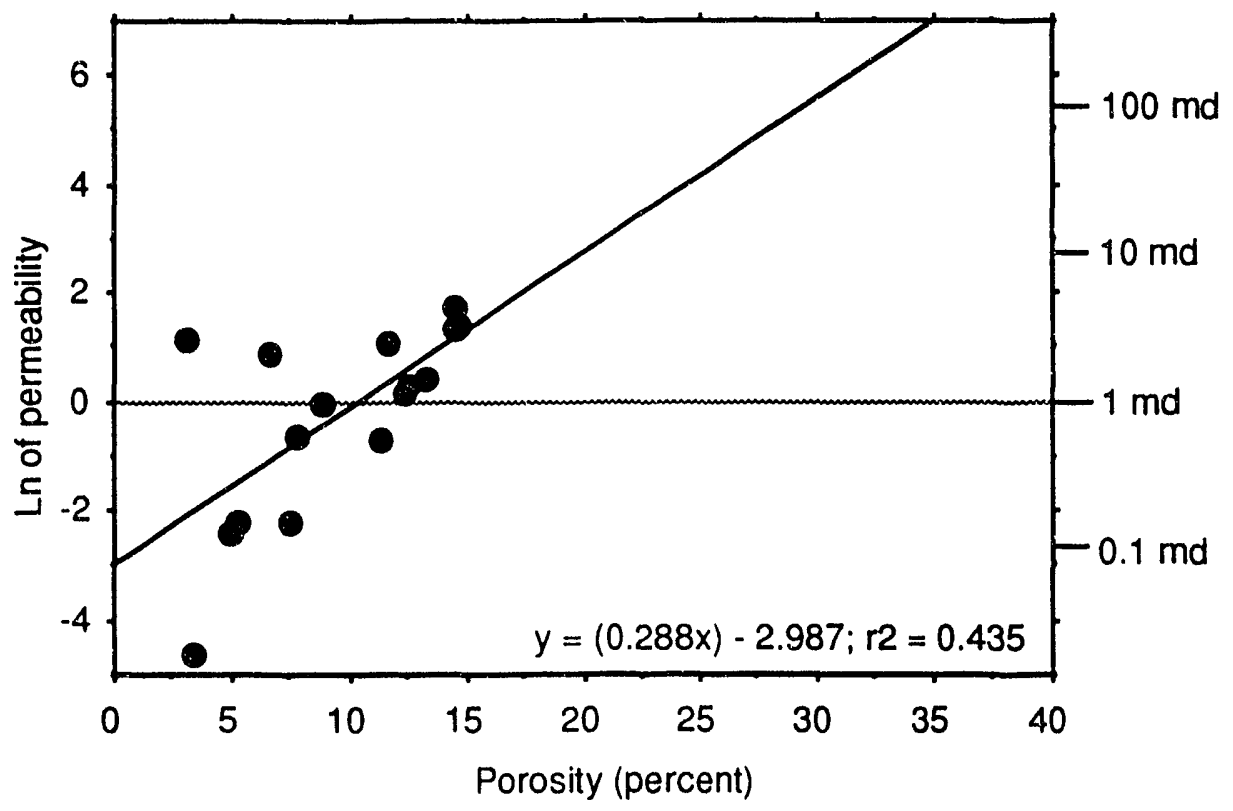

Figure CHU-6.--Porosity vs. natural log permeability plot, Chunchula field, Alabama. (a) Plot of 65 cores combined, and (b) plot of described core for Annie M. Hill et al. No. 1 well, Permit No. 2218. Equations apply to regression lines. 
Table CHU-1.--Reservoir characterization sheet, Smackover pool, Chunchula field, Mobile County, Alabama

\section{Discovery well}

Operator: Union Oil Co. of California

Permit number: 1886

Well Name: I.P.C 22-13 \#1

Location: Sec. 22, T1S-R2W

Completion date: 01/04/74

Perforations: $18,421-18,438 \mathrm{ft}$

Initial flow rate: 1,158 bopd, $2,650 \mathrm{Mcfd}$, $16 / 64 \mathrm{ck}, 2,475 \mathrm{psi}$

\section{Field data (as of 12/31/90)}

Number of wells within field limits: 73

Producing wells in pool: 38

Production wells in field: 38

Shut-in/Temp. abandoned wells: 2

Plugged and abandoned wells: 18

Salt water disposal wells: 6

Enhanced recovery wells: 9

Dry holes: 0

Drilling wells: 0

Unit spacing (acres): Unitized

Total field area (acres): 25,820

Cumulative production

Oil (bbl): 46,959,081

Gas (Mcf): 162,390,935

Water (bbl): $1,571,354$

\section{Reservoir data}

Trap type: Structural / stratigraphic

Reservoir structure: Anticline

Proven productive area (acres): 22,113

Average net pay thickness (feet): 34

Hydrocarbon type: Oil

Oil gravity (API): 60

Initial reservoir pressure (psia): 9,255

Current reservoir pressure (psia): 4,317

Reservoir drive: Depletion

Type of enhanced recovery: Gas injection

Mean porosity (core) (\%): 10.90

Porosity standard deviation (\%): 4.60

Maximum porosity (\%): 26.20

Minimum porosity (\%): 1.10

Number of porosity analyses: 2,396

Geometric mean perm (core) (md): 0.65

Maximum permeability (md): 392.00

Minimum permeability (md): 0.02

Number of permeability analyses: 2,396

Dykstra-Parsons coefficient: na 


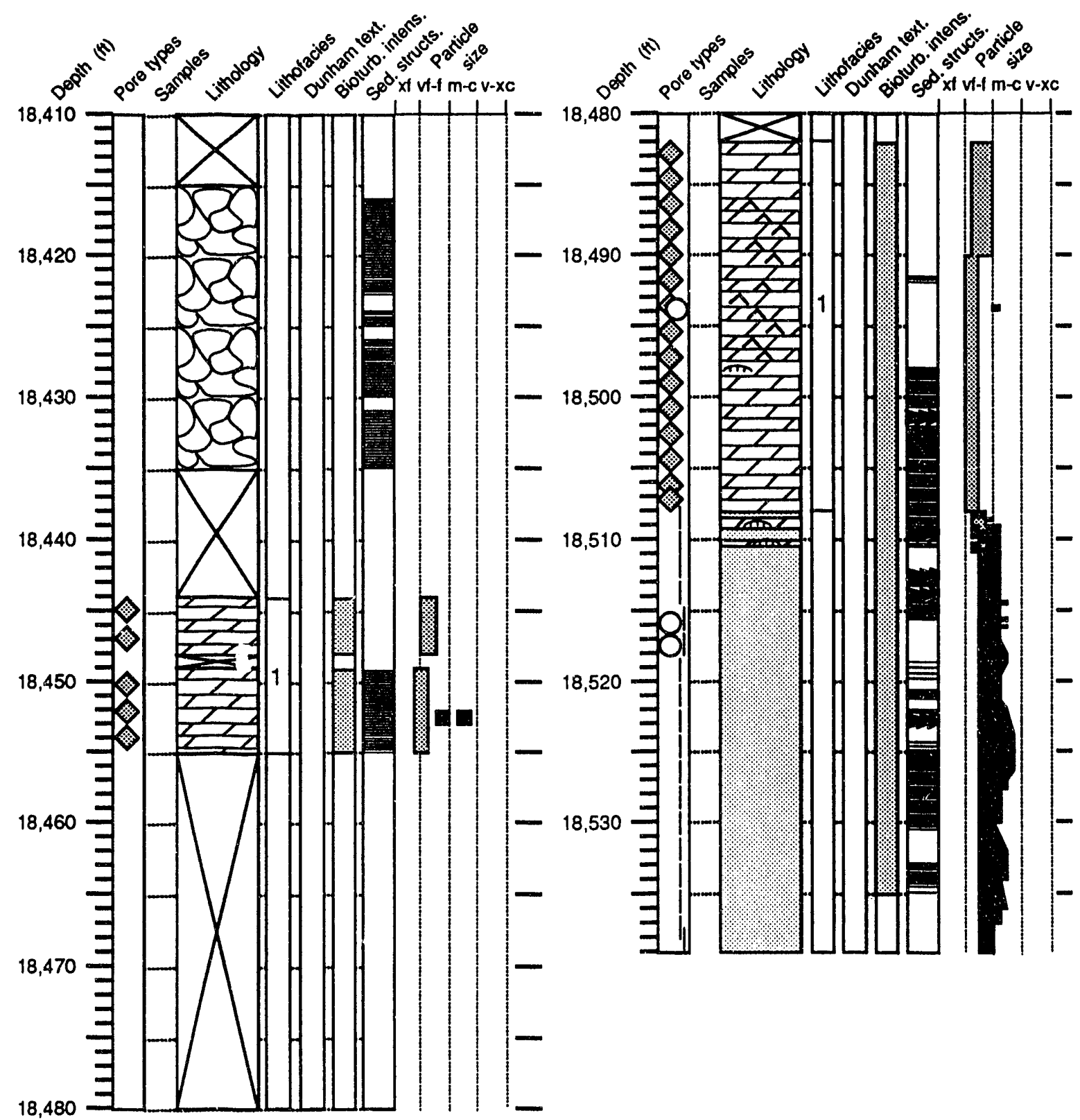

Figure CHU-7.--Detailed core log, Annie M. Hill et al. 10-10 No. 1 well, Permit No. 2218, Chunchula field, Alabama. 
Table CHU-2.--Lithofacies description of core from Annie M. Hill et al. 10-10 No. 1 well, Permit No. 2218, Chunchula field, Alabama (see figure CHU-7)

Lithofacies 1: Crystalline dolostone, locally anhydritic

Pore types:

Intercrystalline: $99 \%$

Moldic: $1 \%$

Mean porosity (\%): 9.9

Maximum porosity (\%): 14.6

Minimum porosity (\%): 3.1

Porosity standard deviation (\%): 3.9

Number of analyses: 15

Geometric mean permeability (md): 1.04

Maximum permeability (md): 5.90

Minimum permeability $(\mathrm{md}): 0.09$

Number of analyses: 15

Depositional Environment: Shallow subtidal marine and/or peritidal hypersaline.

Diagenesis: Early growth of anhydrite nodules and replacement laths, pervasive dolomitization that was not controlled by pre-existing rock fabric.

Percent of reservoir: 100

Depth interval(s) (ft): $18,444-18,508$ 


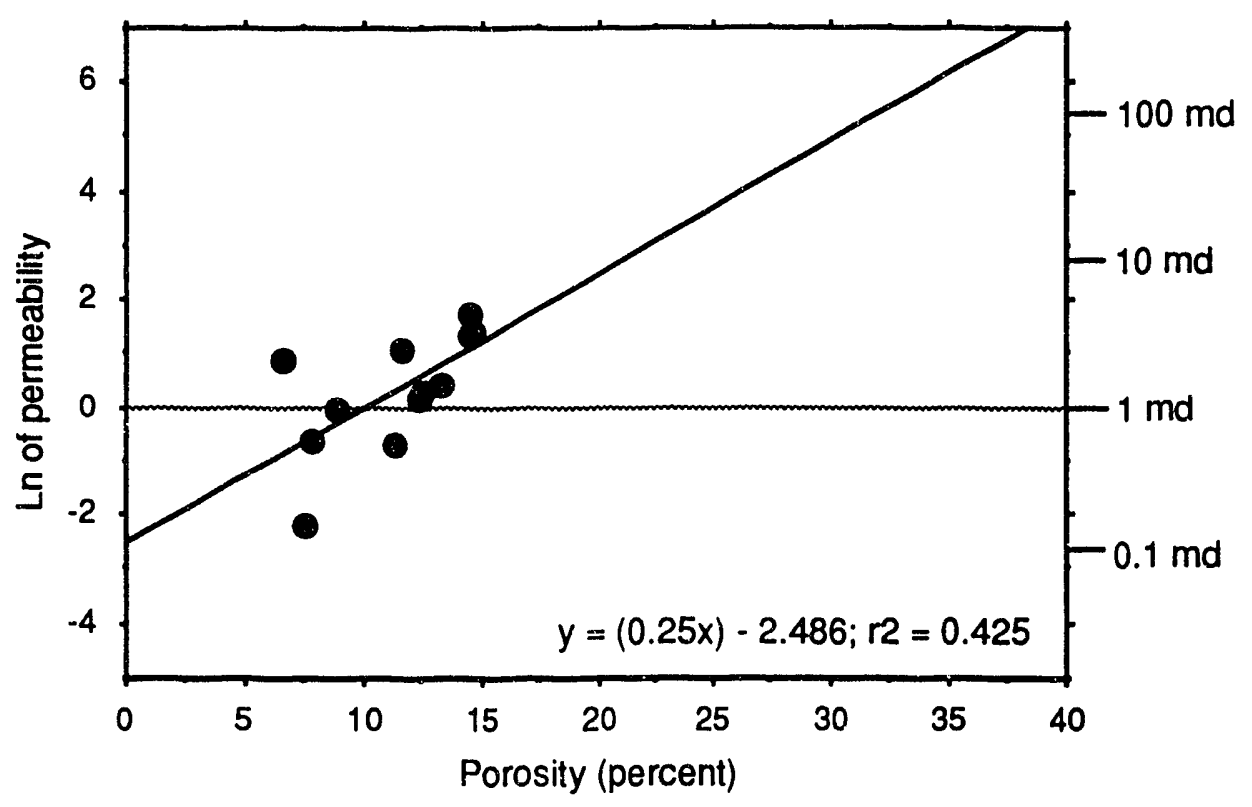

Figure CHU-8.--Porosity vs. natural $\log$ permeability plot for lithofacies 1, Annie M. Hill et al. 10-10 No. 1 well, Permit No. 2218, Chunchula field, Alabama. Equation applies to regression line. (See table CHU-2 for description of lithofacies.) Data set excludes all samples with porosity values and permeability values below reservoir cutoffs at $6 \%$ and $0.1 \mathrm{md}$, respectively. 


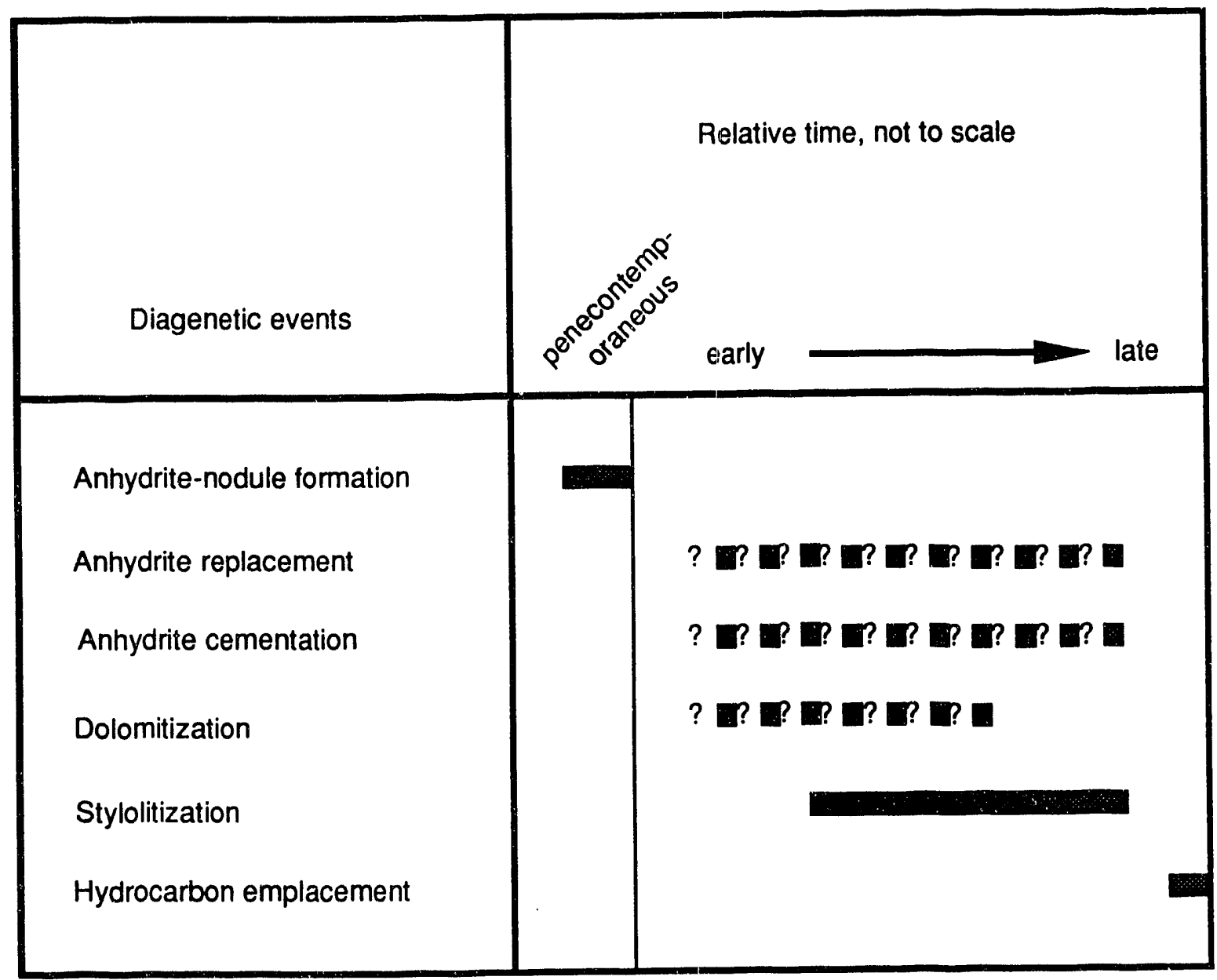

Figure CHU-9.--Paragenetic sequence, Annie M. Hill et al. 10-10 No. 1 well, Permit No. 2218, Chunchula field, Alabama. 


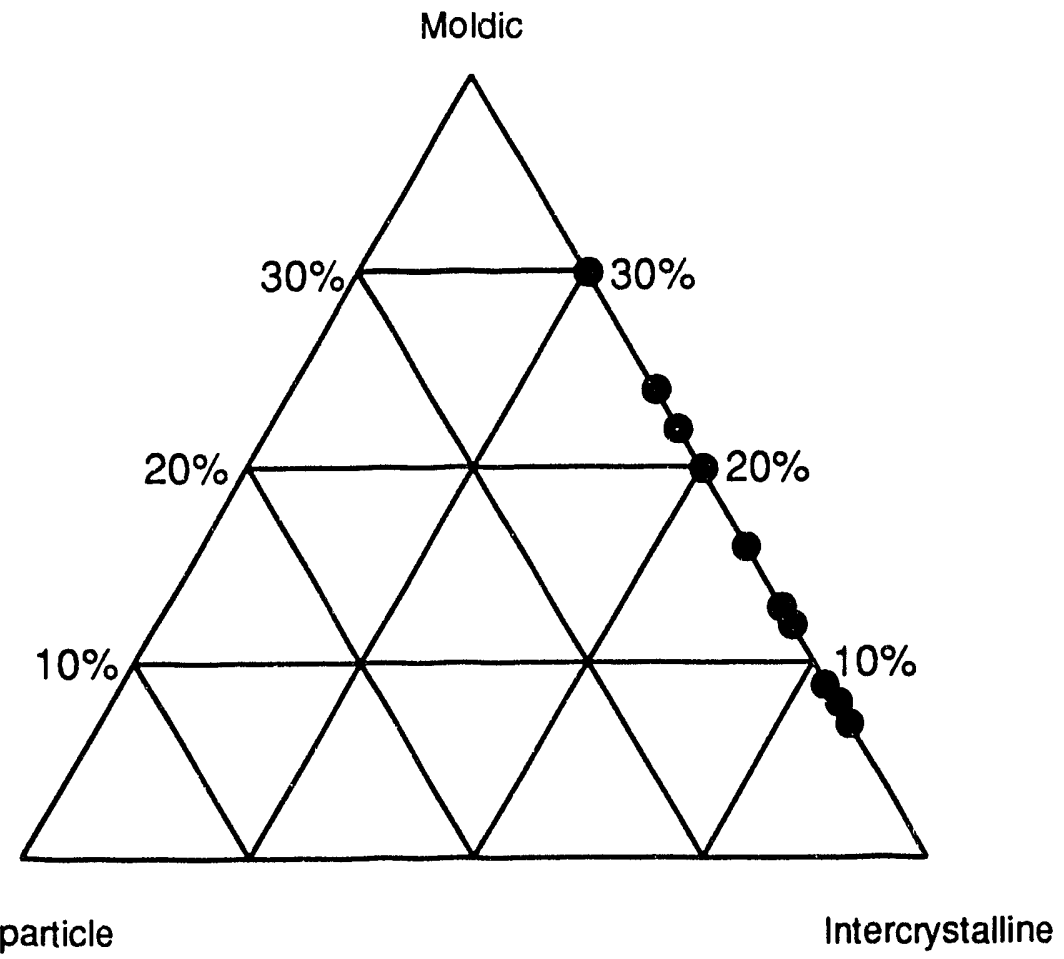

Figure CHU-10.--Ternary diagram of pore types, samples from several wells, Chunchula field, Alabama. Percentages of moldic pores indicated. 


\section{COLD CREEK FIELD}

\section{SMACKOVER OIL POOL}

\section{MOBILE COUNTY, ALABAMA}




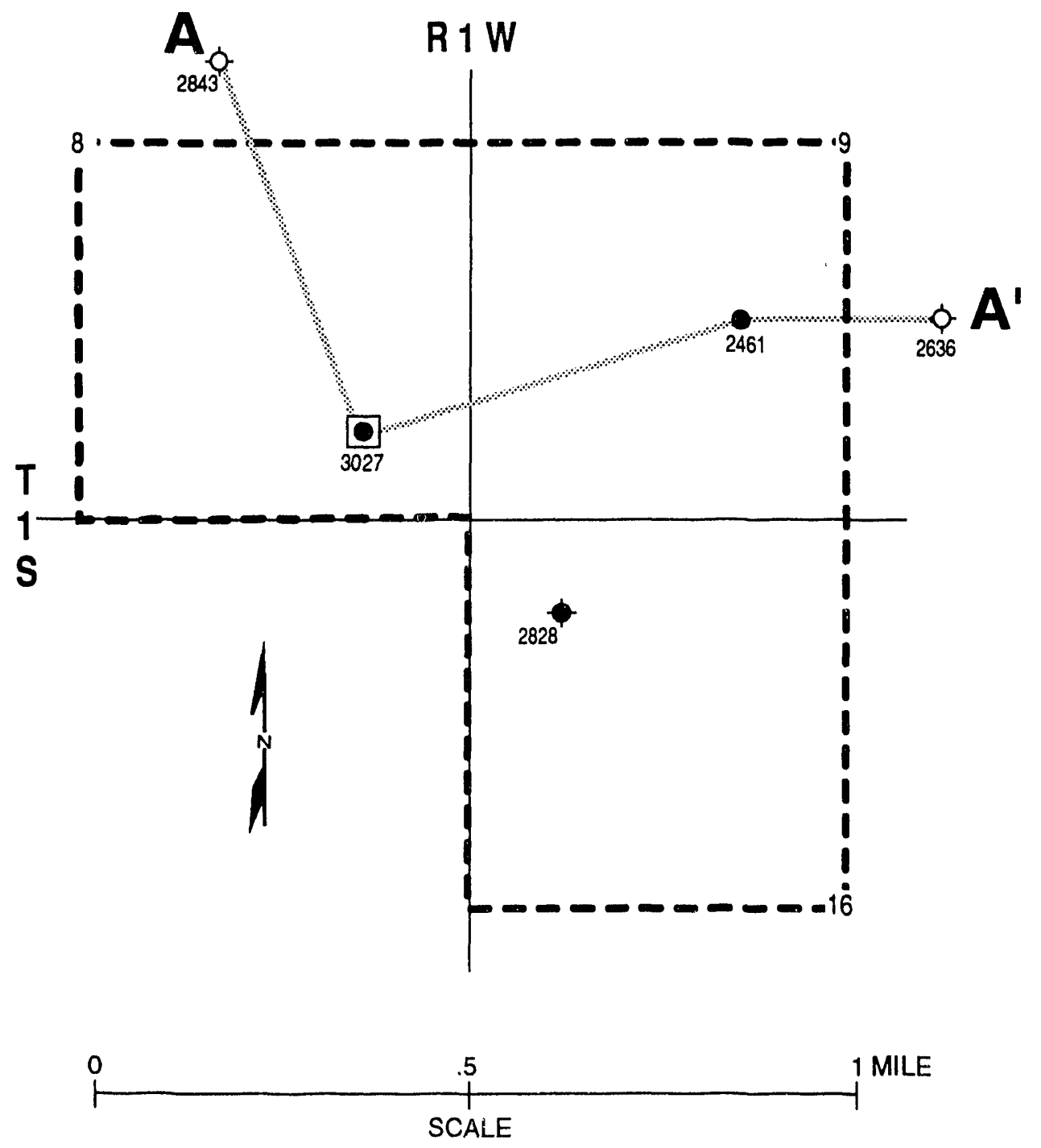

Figure CC-1.--Index map of Cold Creek field, Alabama. 

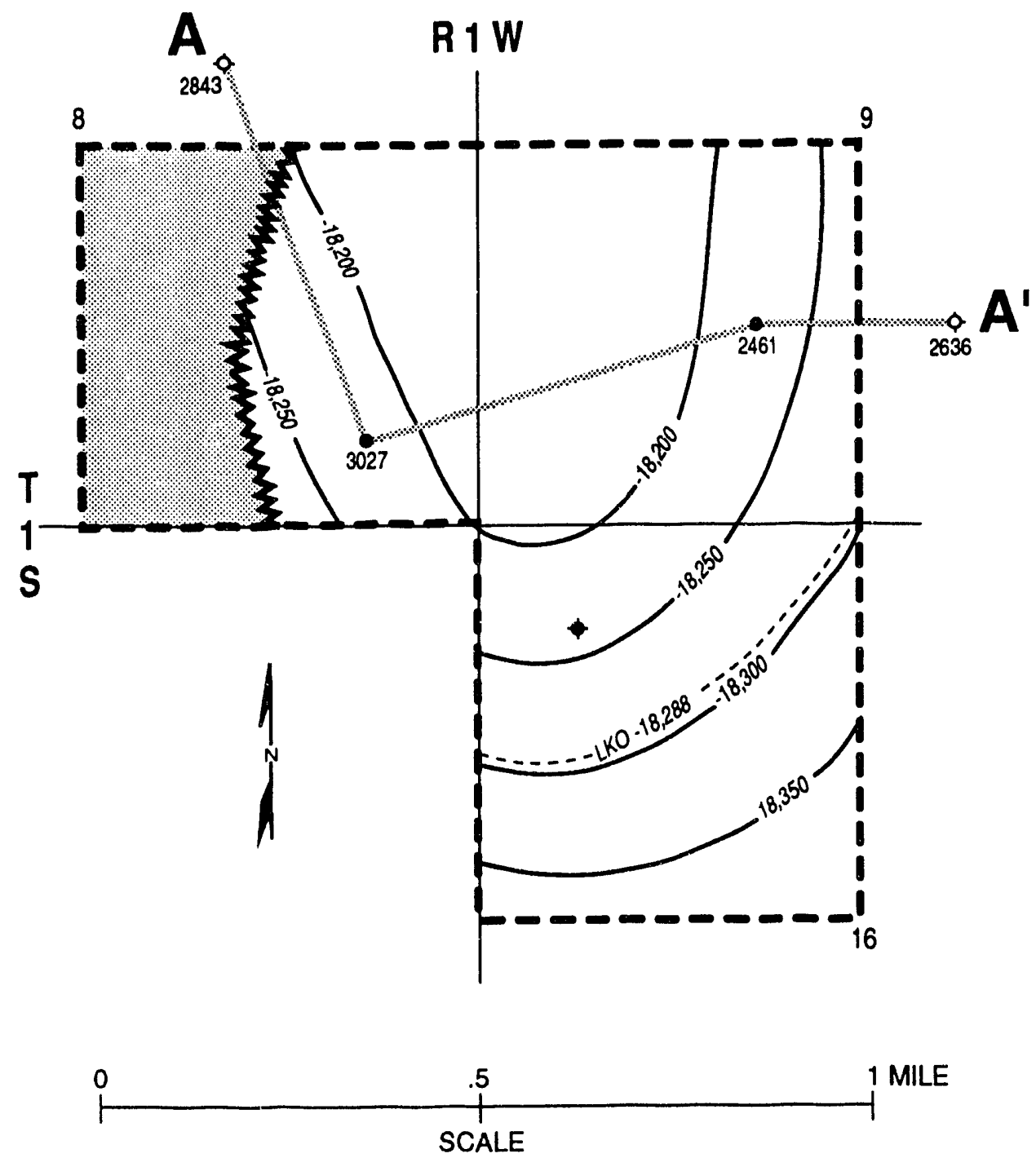

Figure CC-2.--Structure contour map on top of Smackover Formation in Cold Creek field, Alabama. 


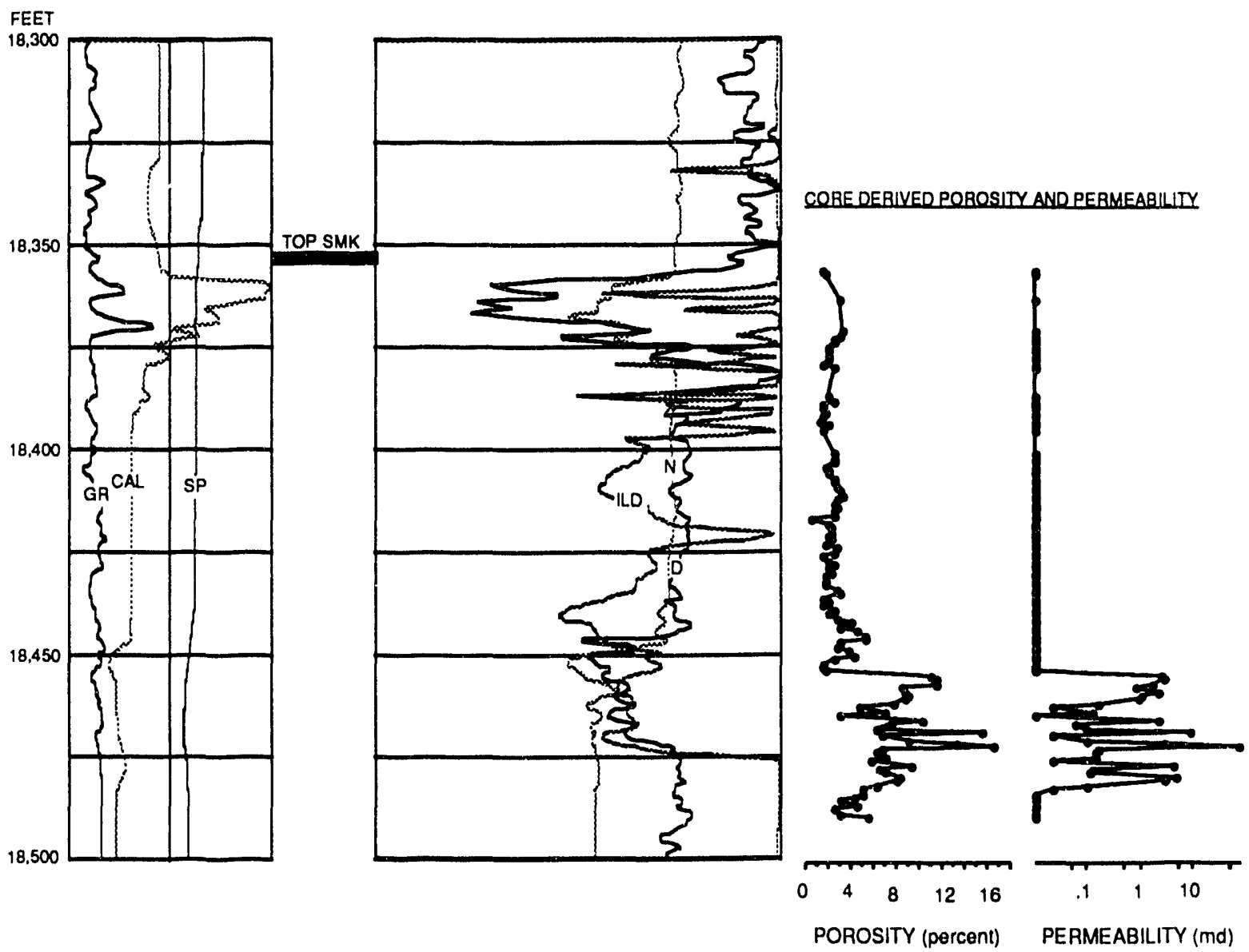

Figure CC-3.--Well log correlated to porosity and permeability, C. P. Newman et al. 8-16 No. 1 well, Permit No. 3027, Cold Creek field, Alabama. 


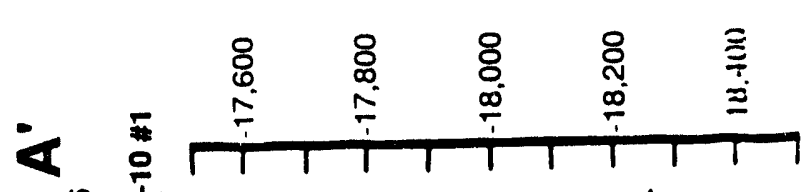

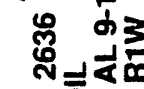

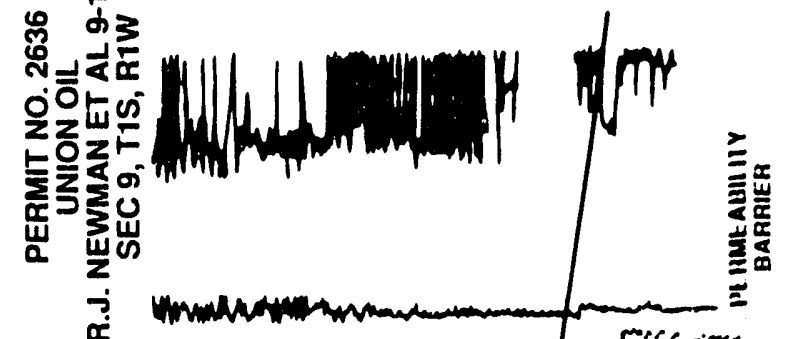

ฮ્.

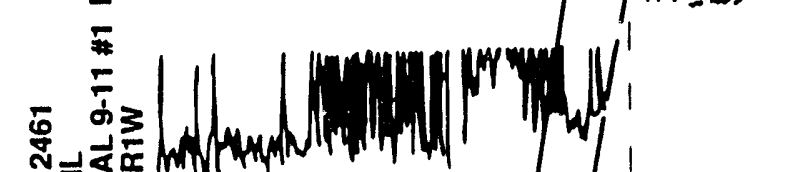



ن

음

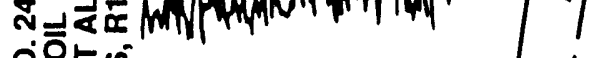
운다

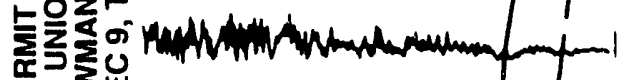

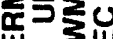

㟧

$\underset{\dot{x}}{\dot{x}}$

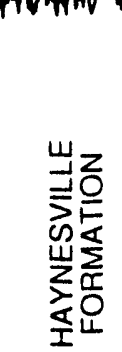

䔲

孚|을

¿̇

옴

ळ

宽

\section{㟒}

点음

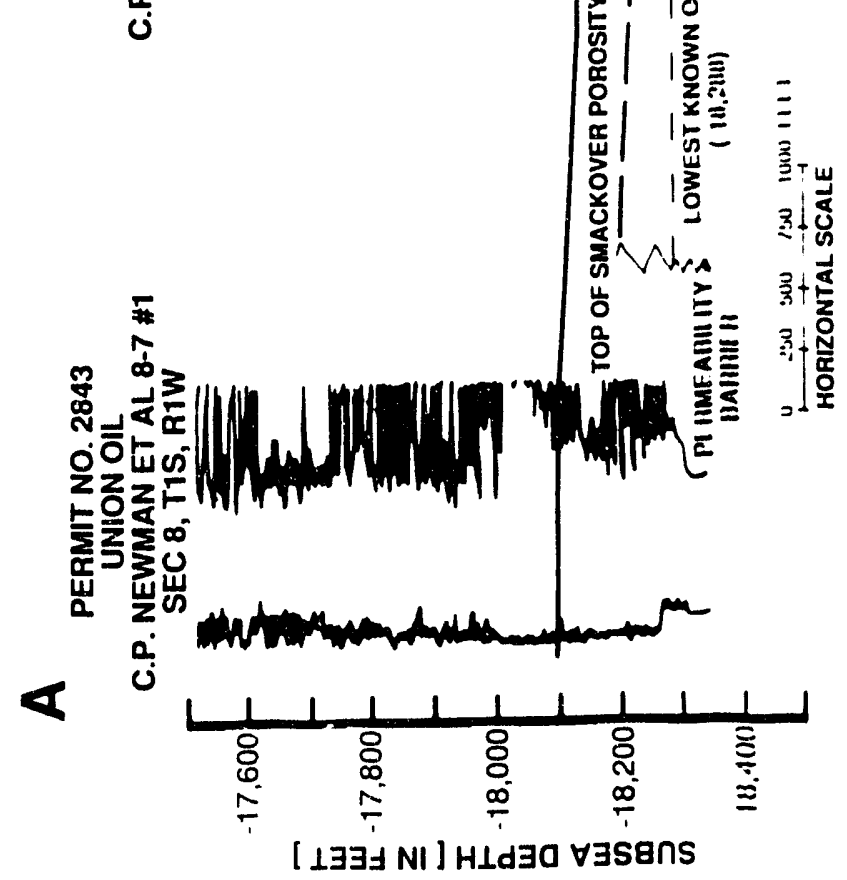

응

$\stackrel{\oplus}{\risingdotseq}$

ธ

은

o

ญ्.

$\frac{0}{0}$

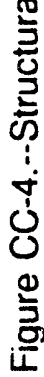




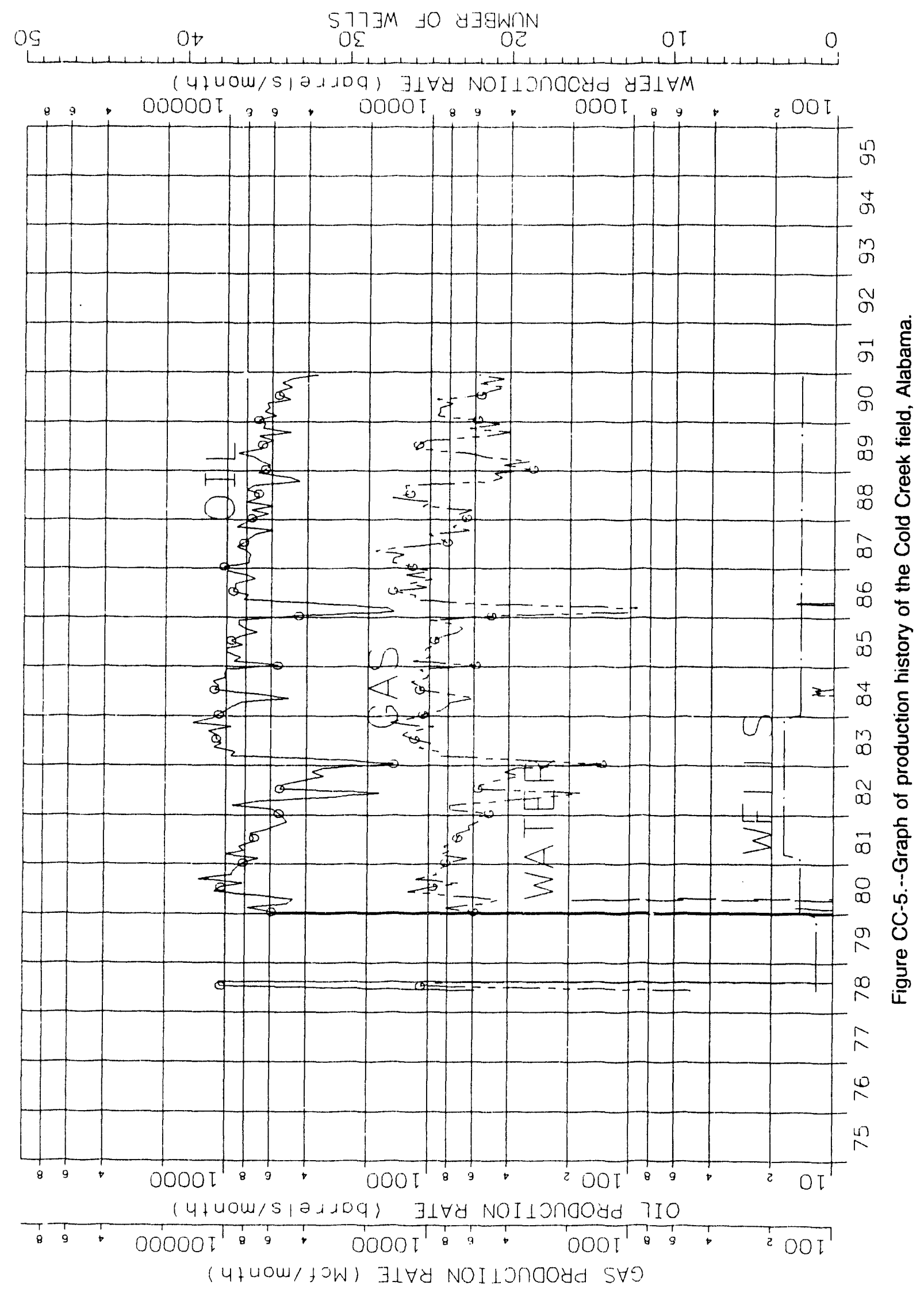


(a)

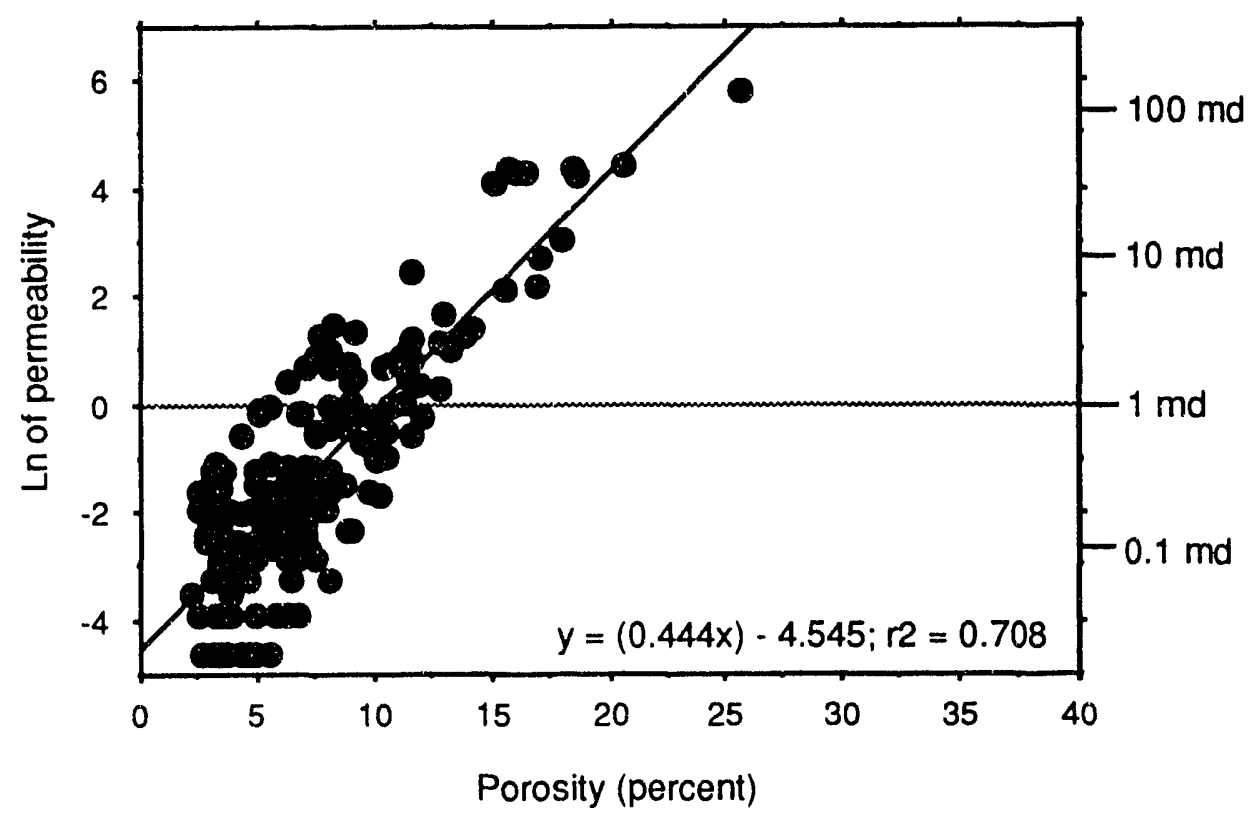

(b)

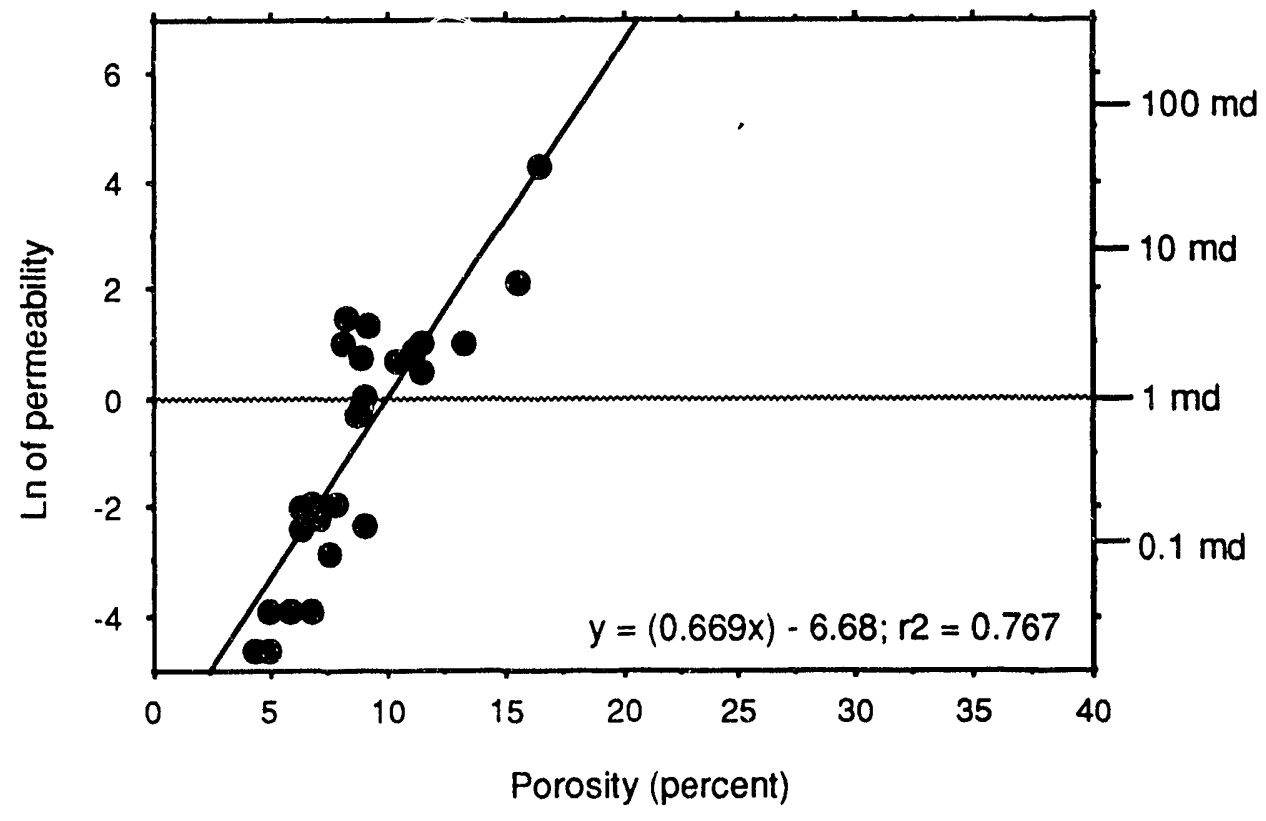

Figure CC-6.--Porosity vs. natural log permeability plots, Cold Creek field, Alabama. (a) Plot of three cores combined, and (b) plot of described core for C. P. Newman et al. 8-16 No. 1 well, Permit No. 3027. Equations apply to regression lines. 
Table CC-1.--Reservoir characterization sheet, Smackover pool, Cold Creek field, Mobile County, Alabama

\section{Discovery well}

Operator: Union Oil Co. of California

Permit number: 2461

Well Name: R.J. Newman et al 9-11 \#1

Location: Sec. 9, T1S-R1W

Completion date: $04 / 18 / 78$

Perforations: $18,425-18,443 \mathrm{ft}$

Initial flow rate: 500 bopd, 320 Mcfd,

14/64 ck, 810 psi

Field data (as of 12/31/90)

Number of wells within field limits: 3

Producing wells in pool: 2

Production wells in field: 2

Shut-in/Temp. abandoned wells: 0

Plugged and abandoned wells: 1

Salt water disposal wells: 0

Enhanced recovery wells: 0

Dry holes: 0

Drilling wells: 0

Unit spacing (acres): 160

Total field area (acres): 480

Cumulative production

Oil (bbl): 999,846

Gas (Micf): 1,111,743

Water (bbl): j,499

\section{Reservoir data}

Trap type: Structural / stratigraphic

Reservoir structure: Anticline

Proven productive area (acres): 625

Average net pay thickness (feet): 20

Hydrocarbon type: Oil

Oil gravity (API): 59

Initial reservoir pressure (psia): 8,911

Current reservoir pressure (psia): 4,827

Reservoir drive: Solution gas

Type of enhanced recovery: na

Mean porosity (core) (\%): 4.25

Porosity standard deviation (\%): 3.51

Maximum porosity (\%): 25.50

Minimum porosity (\%): 0.50

Number of porosity analyses: 512

Geometric mean perm (core) (md): 0.26

Maximum permeability (md): 327.00

Minimum permeability (md): 0.01

Number of permeability analyses: 201

Dykstra-Parsons coefficient: na 
COPELAND FIELD

SMACKOVER GAS AND CONDENSATE POOL

WASHINGTON COUNTY, ALABAMA 


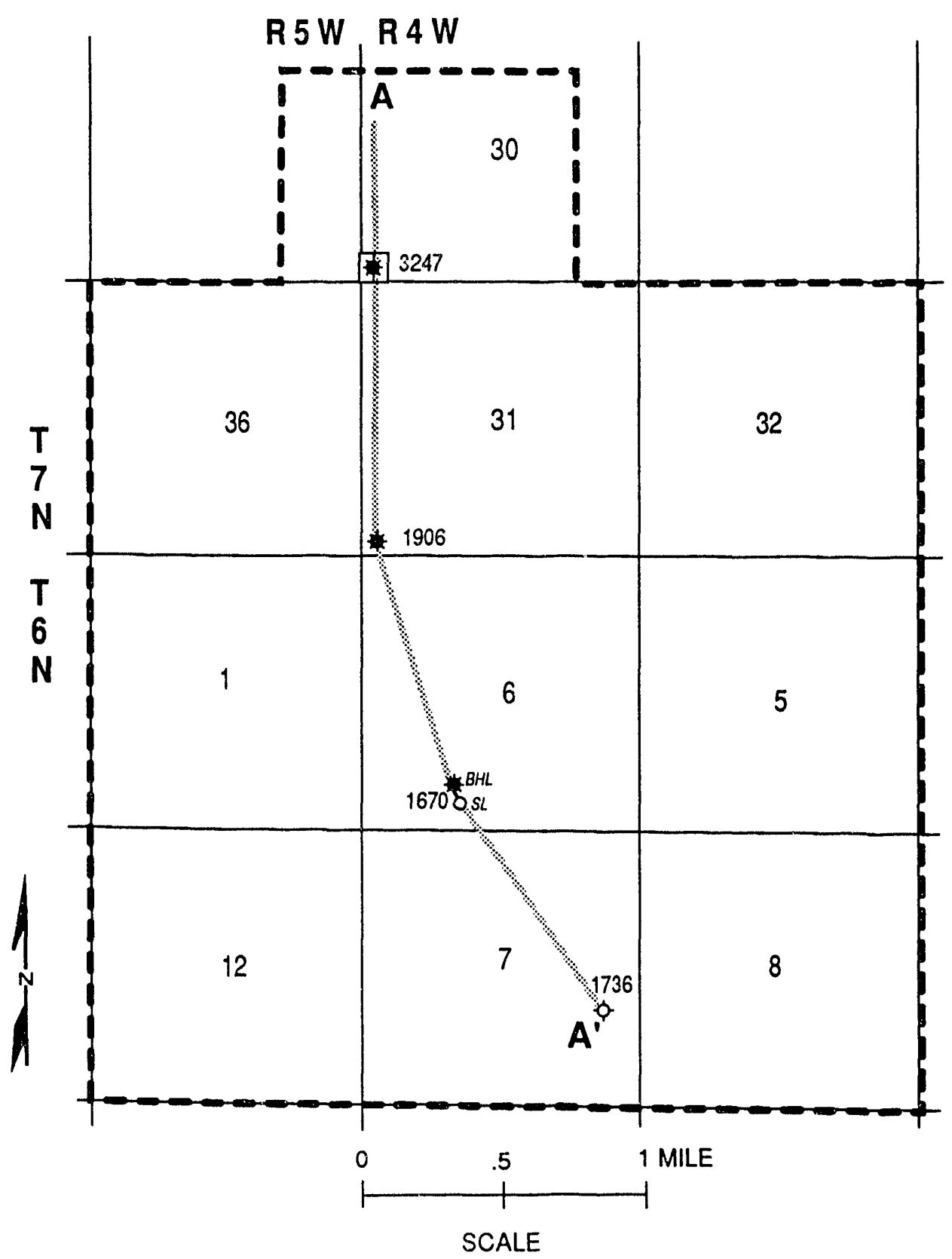

Figure CPL-1.--Index map of Copeland field, Alabama. 


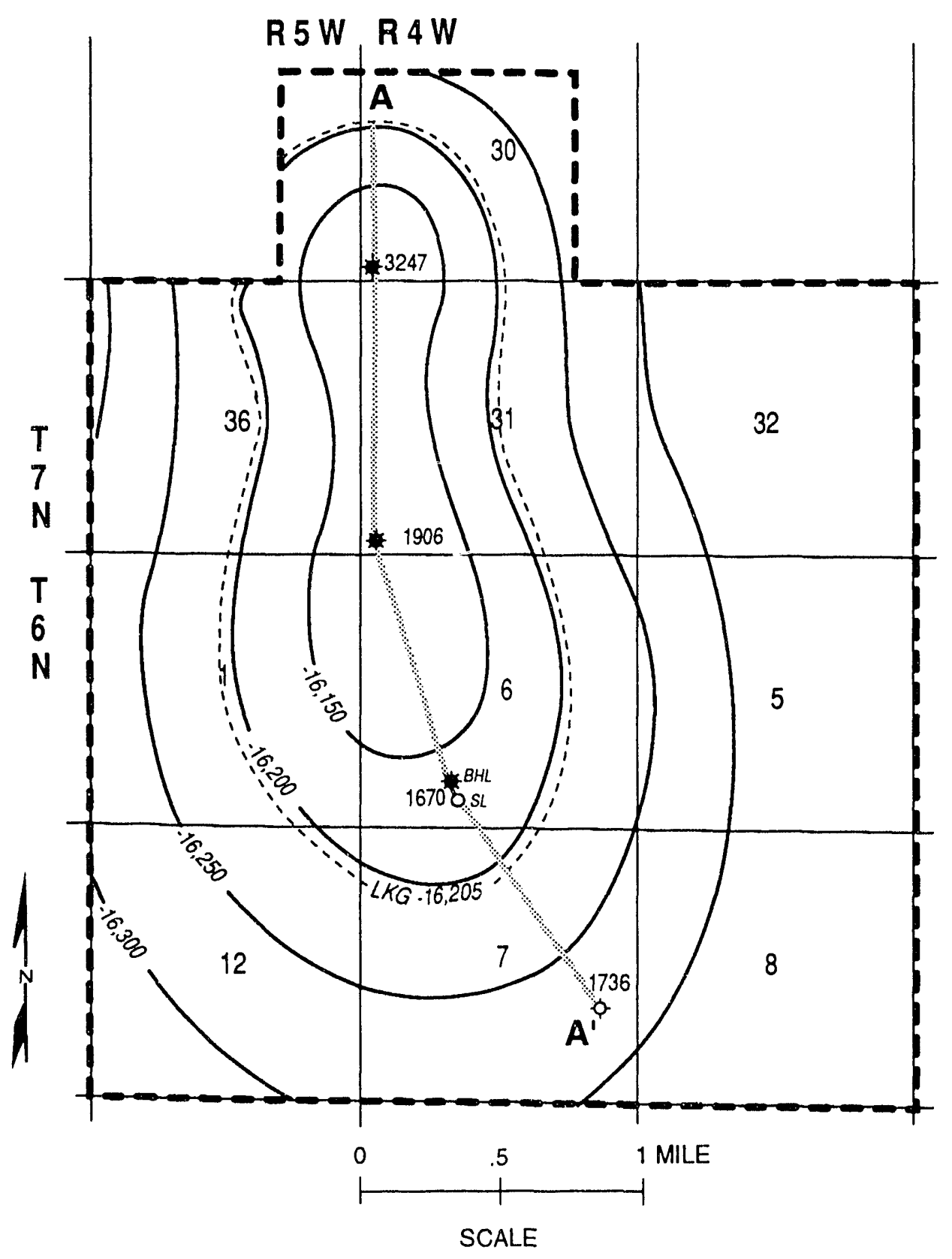

Figure CPL-2.--Structure contour map on top of Smackover Formation in Copeland field, Alabama 


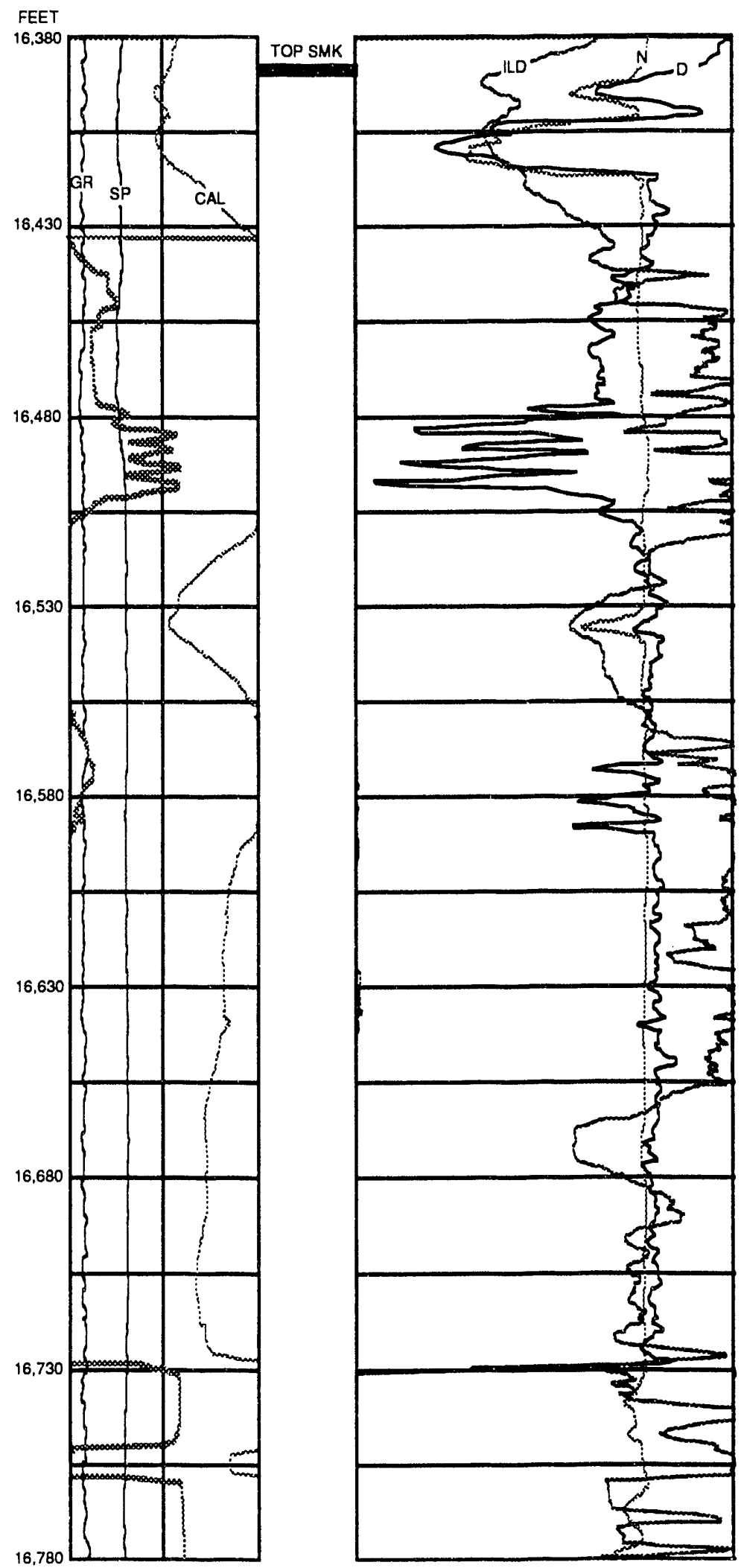

Figure CPL-3.--Well log, Edith Burch 30-13 No. 1 well, Permit No. 3247, Copeland field, Alabama. 


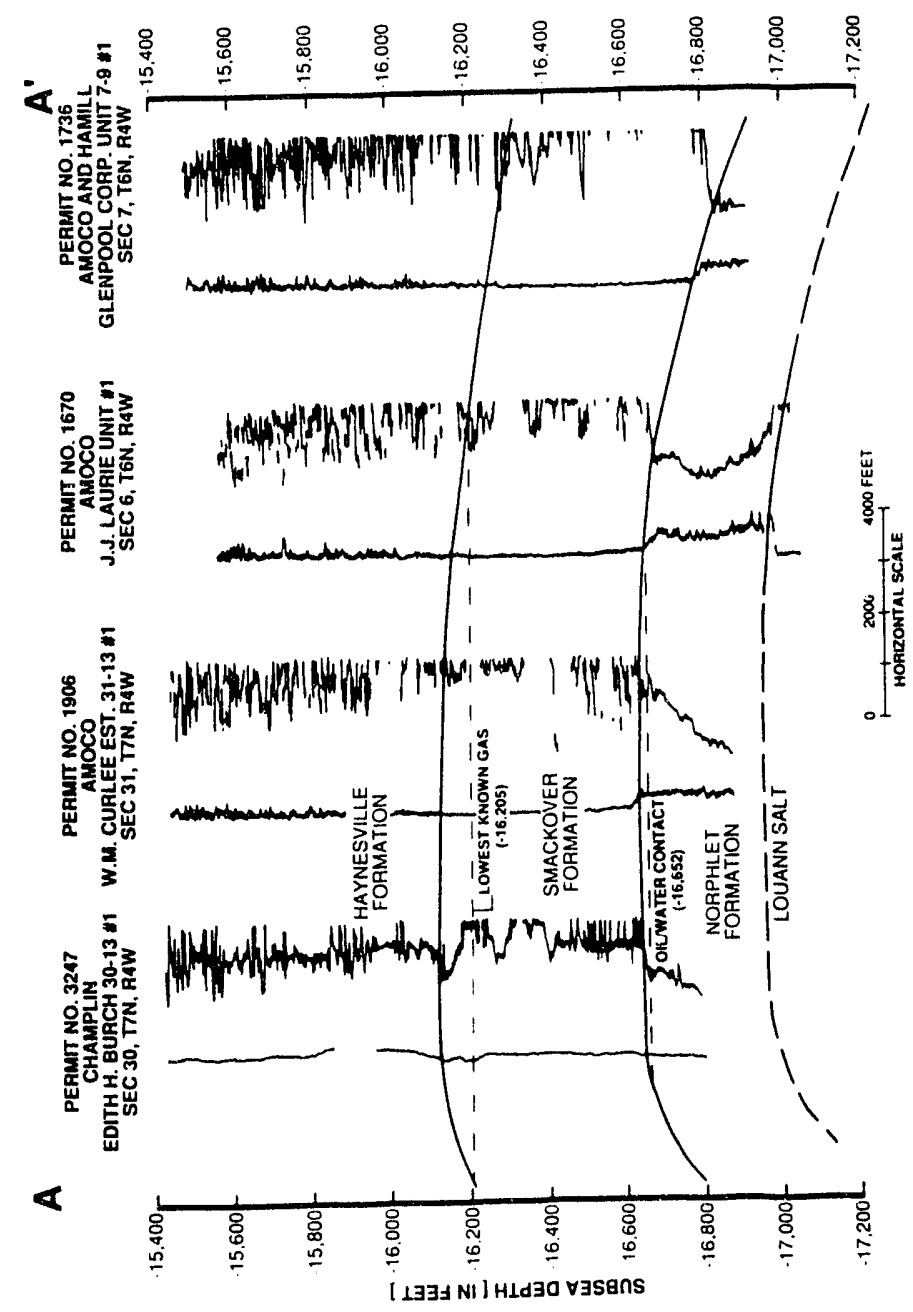




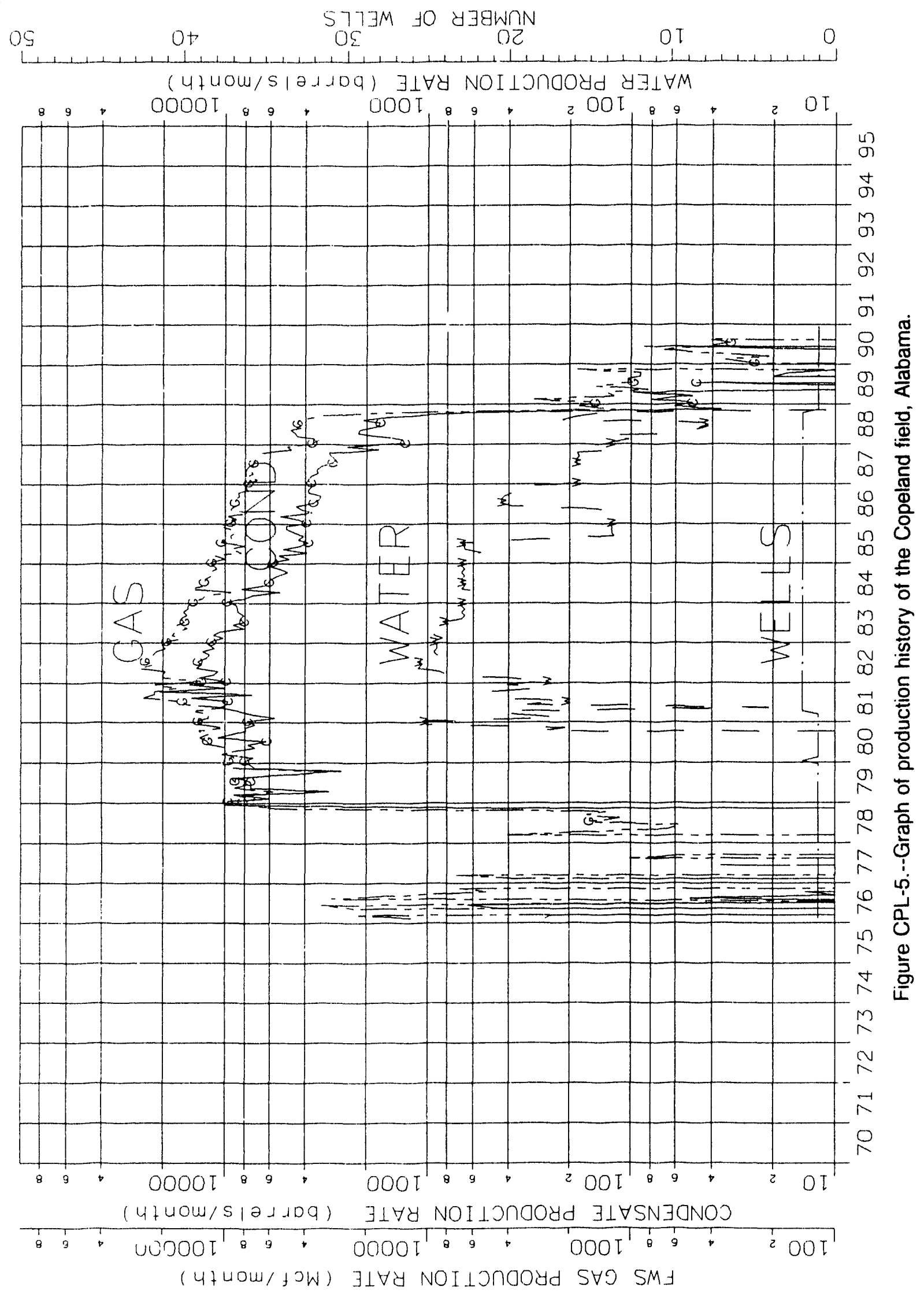




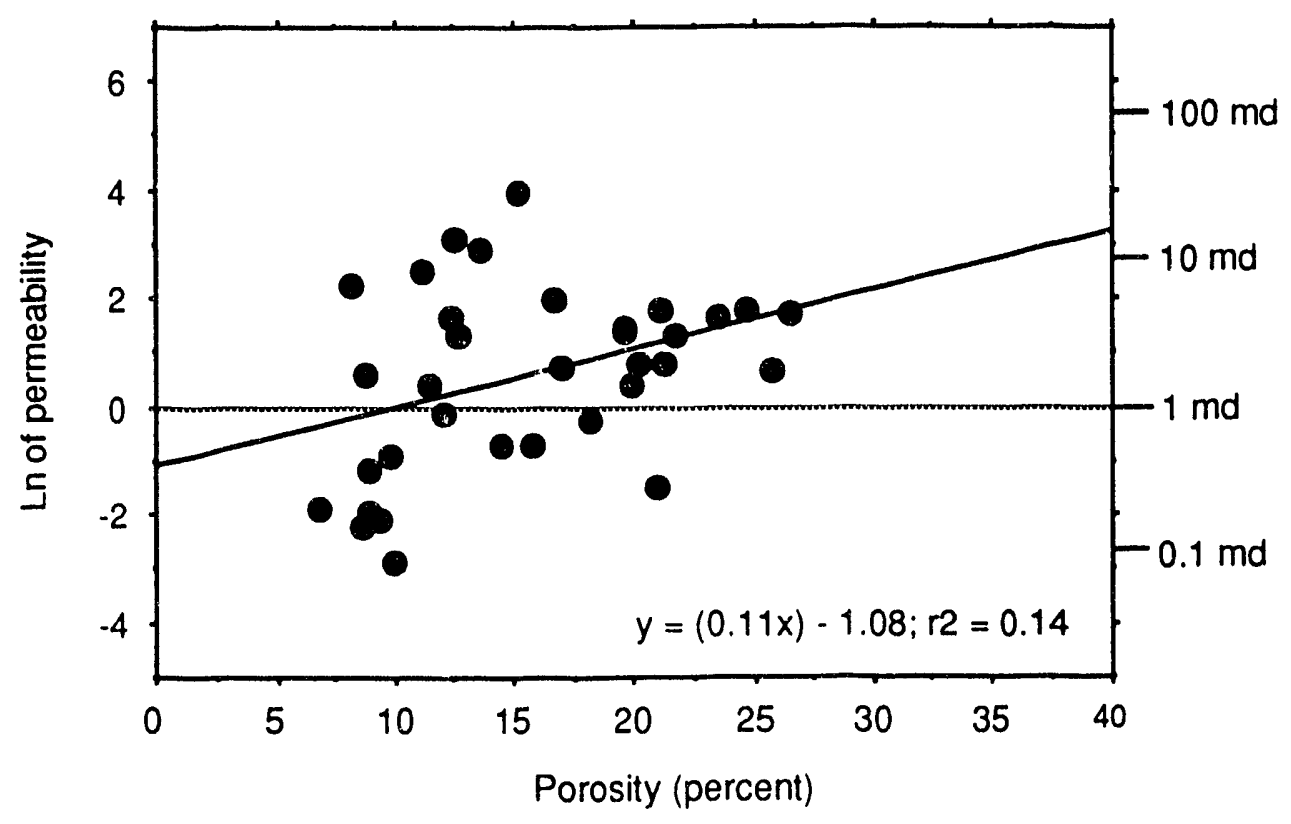

Figure CPL-6.--Porosity vs. natural log permeability plot of one core, Copeland field, Alabama. Equation applies to regression lines. 
Table CPL-1.--Reservoir characterization sheet, Smackover pool, Copeland field, Washington County, Alabama

\section{Discovery well}

Cperator: Amoco Production Co.

Permit number: 1670

Well Name: J.J. Laurie Unit \#1

Location: Sec. 6, T6N-R4W

Completion date: $\mathrm{v} 2 / 10 / 72$

Perforations: $16,614-16,630,16,800-16,835 \mathrm{ft}$

Iritial flow rate: 31 bcpd, 1,519 Mcfd,

$$
30 / 64 \text { ck, } 800 \text { psi }
$$

\section{Field data (as of 12/31/90)}

Number of wells within field limits: 4

Producing wells in pool: 2

Production wells in field: 2

Shut-in/Temp. abandoned wells: 1

Plugged and abandoned wells: 0

Salt water disposal wells: 0

Enhanced recovery wells: 0

Dry holes: 1

Drilling wells: 0

Unit spacing (acres): 640

Total field area (acres): 6,240

Cumulative production

Condensate (bbl): 813,586

Gas (Mcf): $13,993,943$

Water (bbl): 1,131

\section{Reservolr data}

Trap type: Structural

Reservoir structure: Anticline

Proven productive area (acres): 1,703

Average net pay thickness (feet): 14

Hydrocarbon type: Gas condensate

Oil gravity (API): 41

Initial reservoir pressure (psia): 7,899

Current reservoir pressure (psia): 3,015

Reservoir drive: Depletion

Type of enhanced recovery: none

Mean porosity (core) (\%): 15.40

Porosity standard deviation: 5.74

Maximum porosity (\%): 26.40

Minimum porosity (\%): 6.70

Number of porosity analyses: 34

Geometric mean perm (core) (md): 1.80

Maximum permeability (md): 52.00

Minimum permeability (md): 0.06

Number of permeability analyses: 34

Dykstra-Parsons coefficient: na 
CROSBYS CREEK FIELD

SMACKOVER GAS AND CONDENSATE POOL

\section{WASHINGTON COUNTY, ALABAMA}




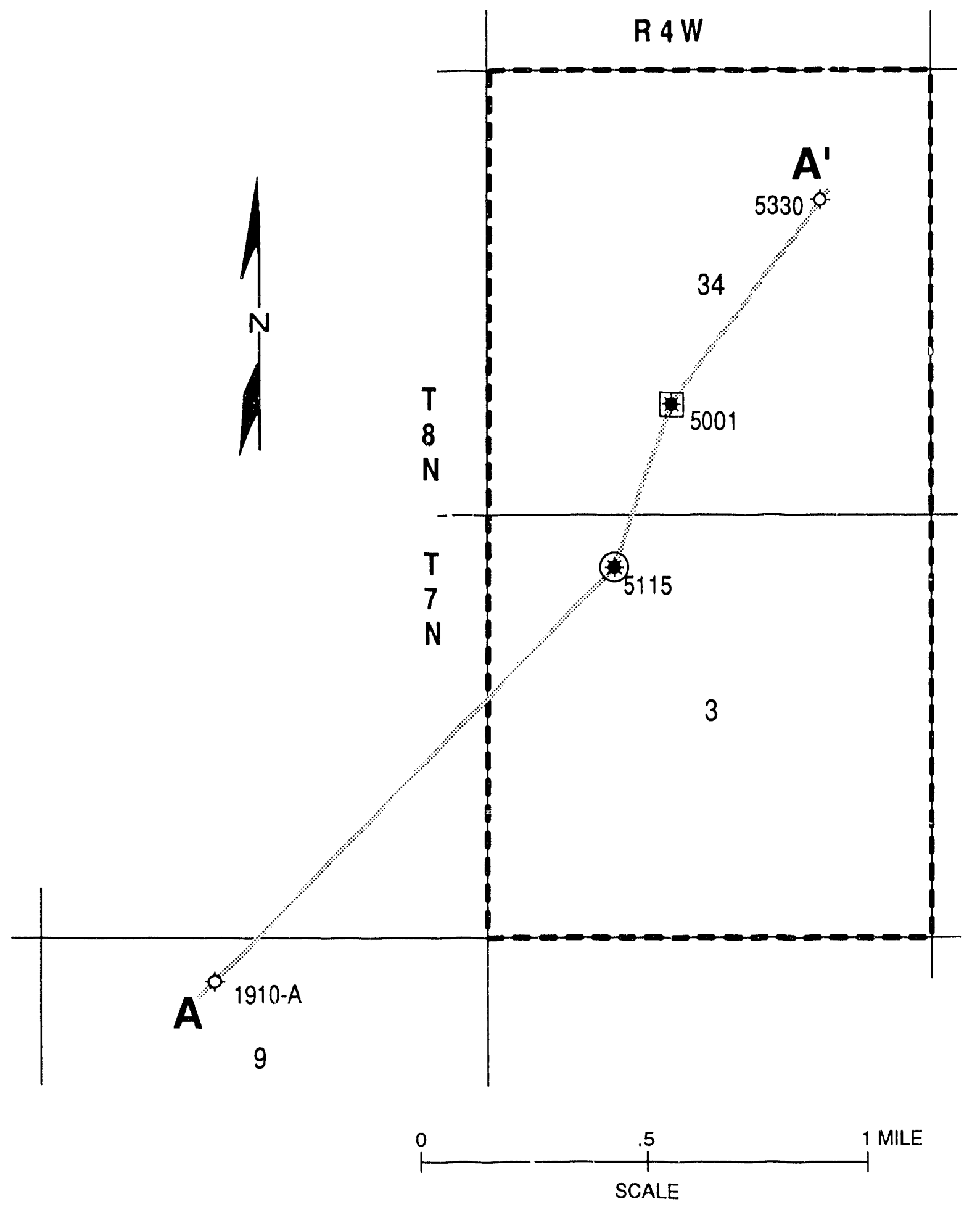

Figure CRC-1.--Index map of Crosbys Creek field, Alabama. 


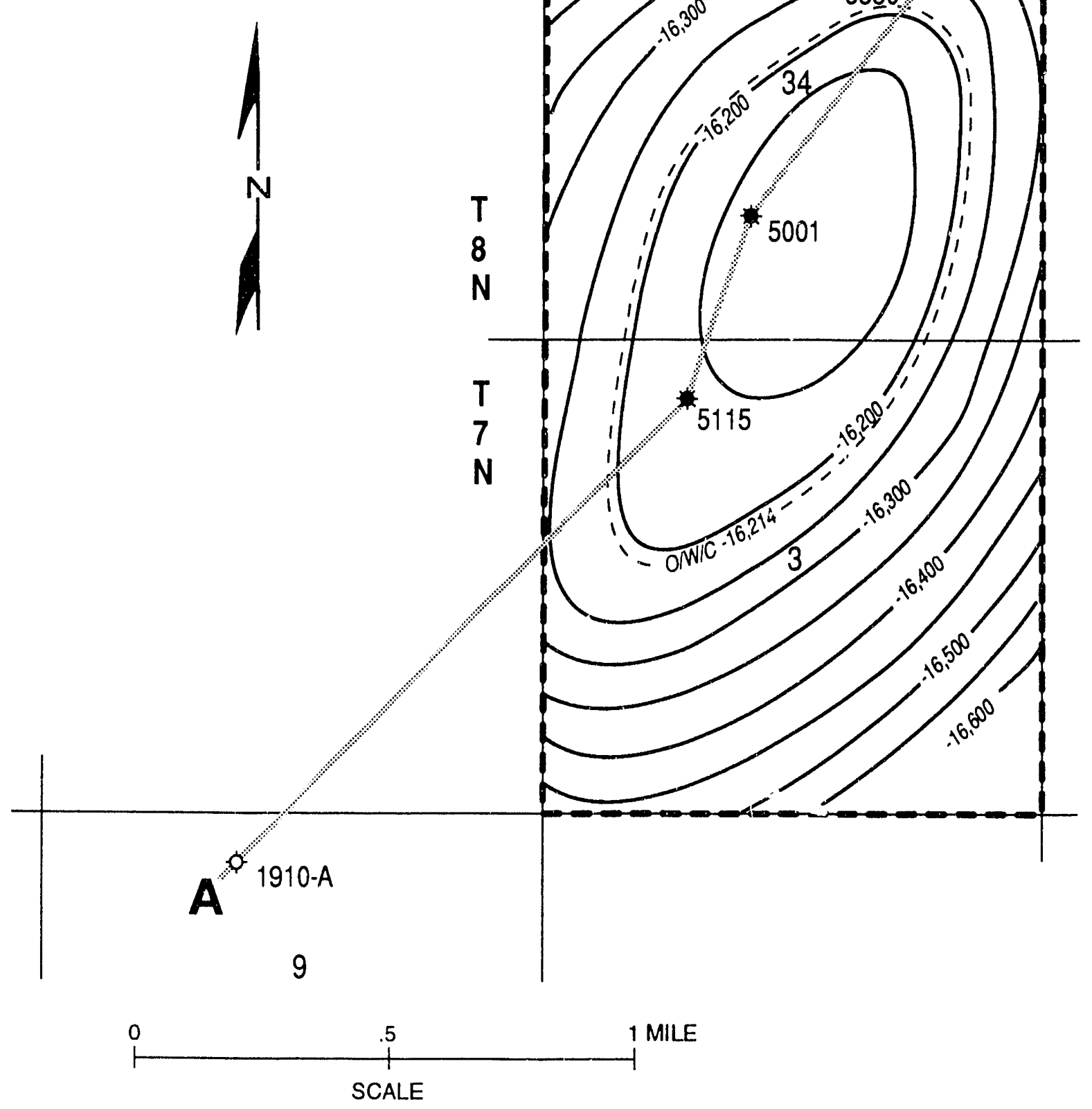

Figure CRC-2.--Structure contour map on top of Smackover Formation in Crosbys Creek field, Alabama. 


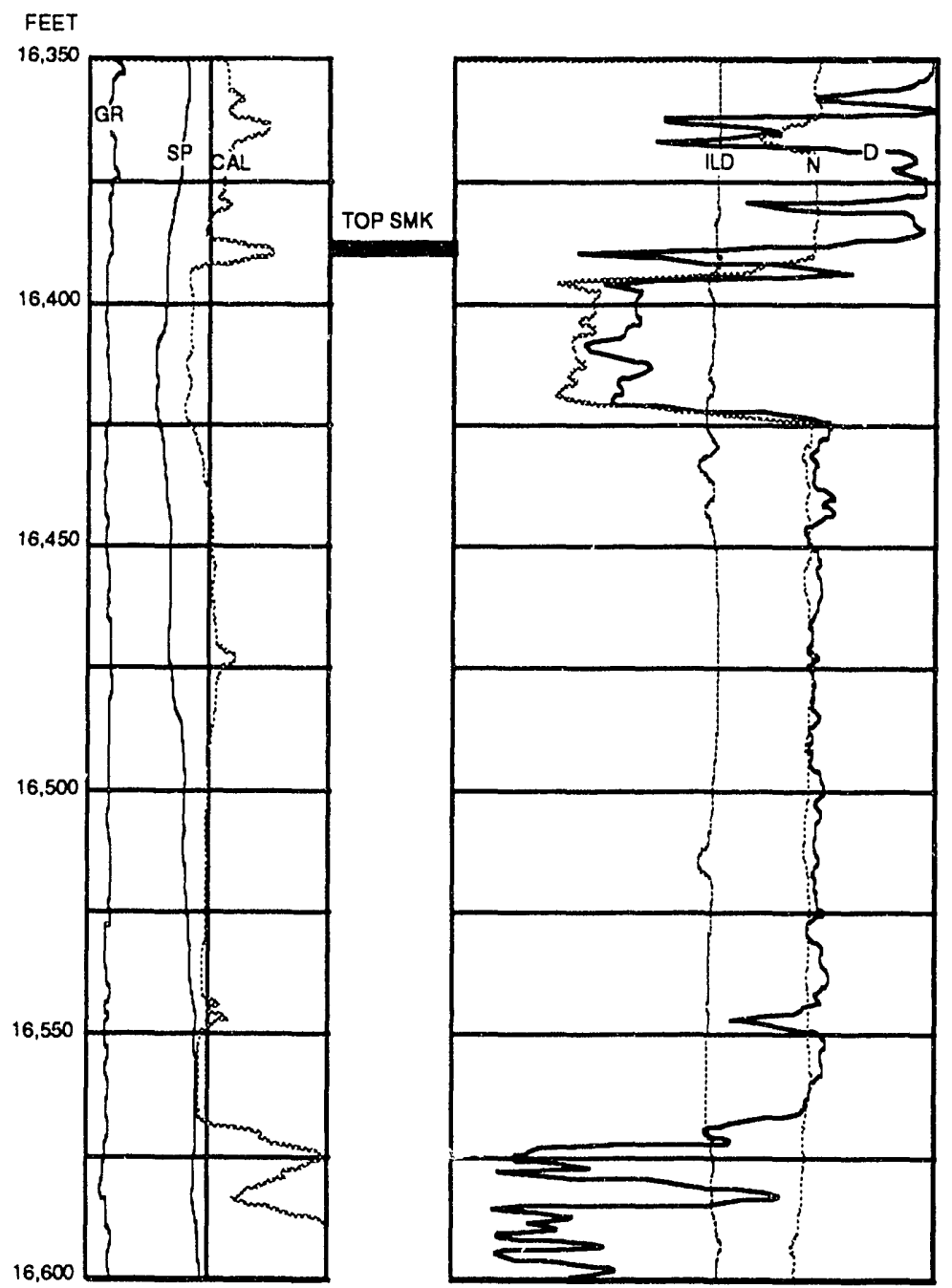

Figure CRC-3.--Well log, Sarah Middleton 34-11 No. 1 well, Permit No. 5001, Crosbys Creek field, Alabama. 
A

PERMIT NO 1910-A

TENNECO OIL CO.-WILLIAMS AND PENNZOIL -1-A JACK L. HOPKINS ET AL SEC $9, T 7 N, R 4 W$
PERMIT NO. 5115

HUGHES EASTERN CORP.

DARLY DEES 3-3

SEC 3,T7N,R4W
PERMIT NO. 5330

HUGHES EASTERN CORP.

-1 TURNER-WHITE HEIRS 34-7 SEC 34,T8N,R4W HUGHE: EASTERN PETROLEUM LTD.

1 SARA MIDDLETON 34-11

SEC 34,T8N,R4W

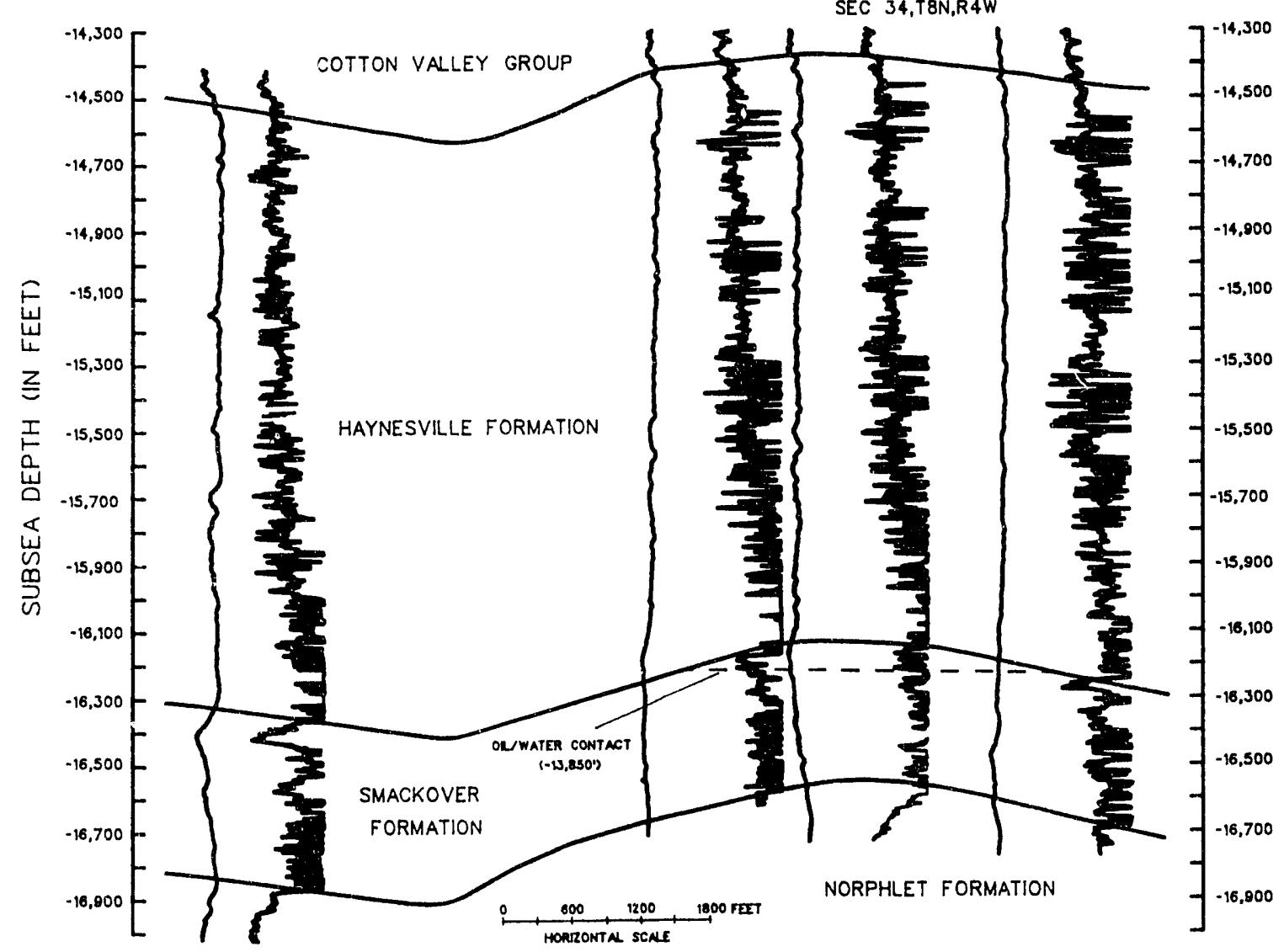

Figure CRC-4--Structural cross section of the Crosbys Creek field, Alabama.

(See figures CRC-1 and CRC-2 for line of section.) 


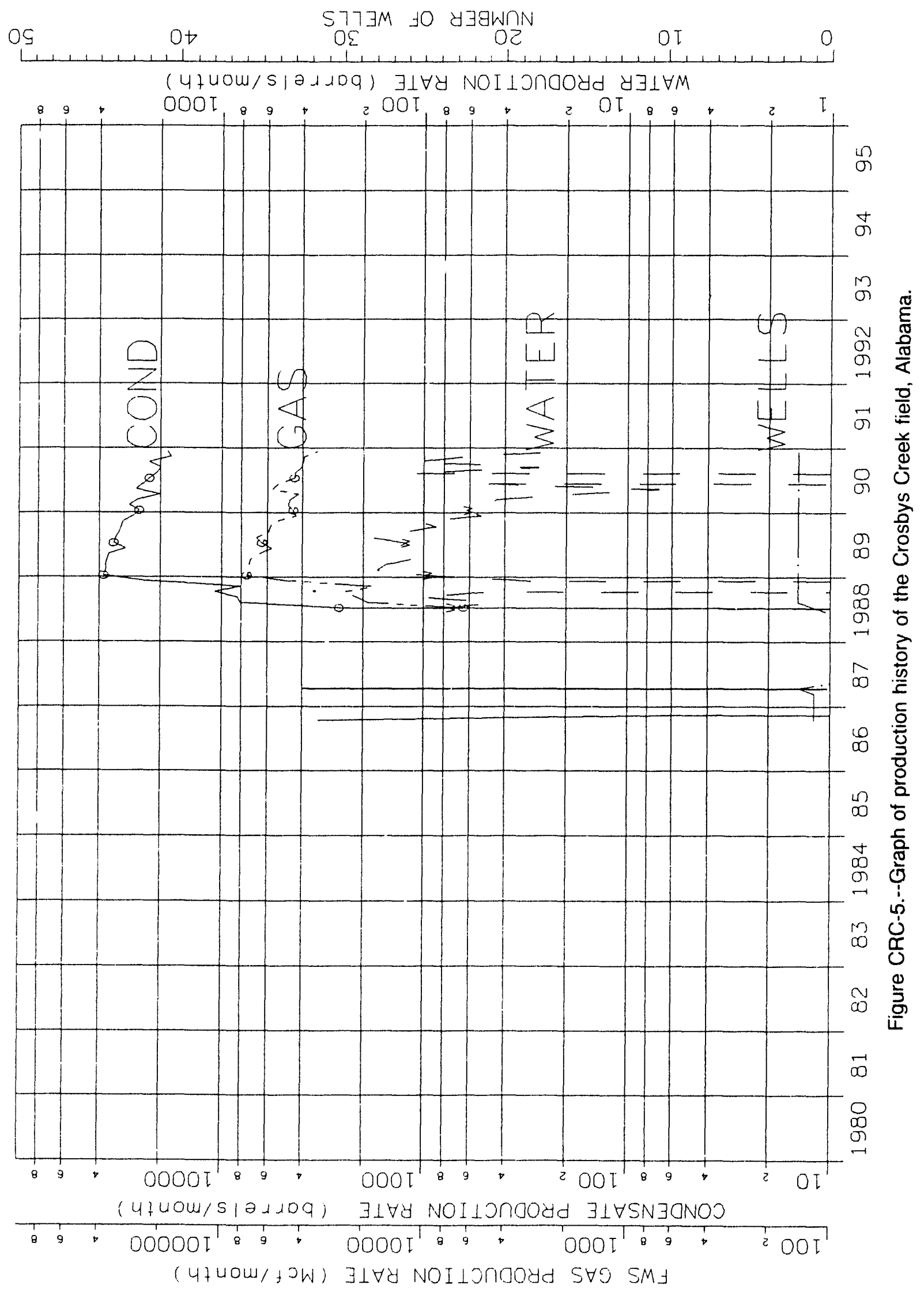




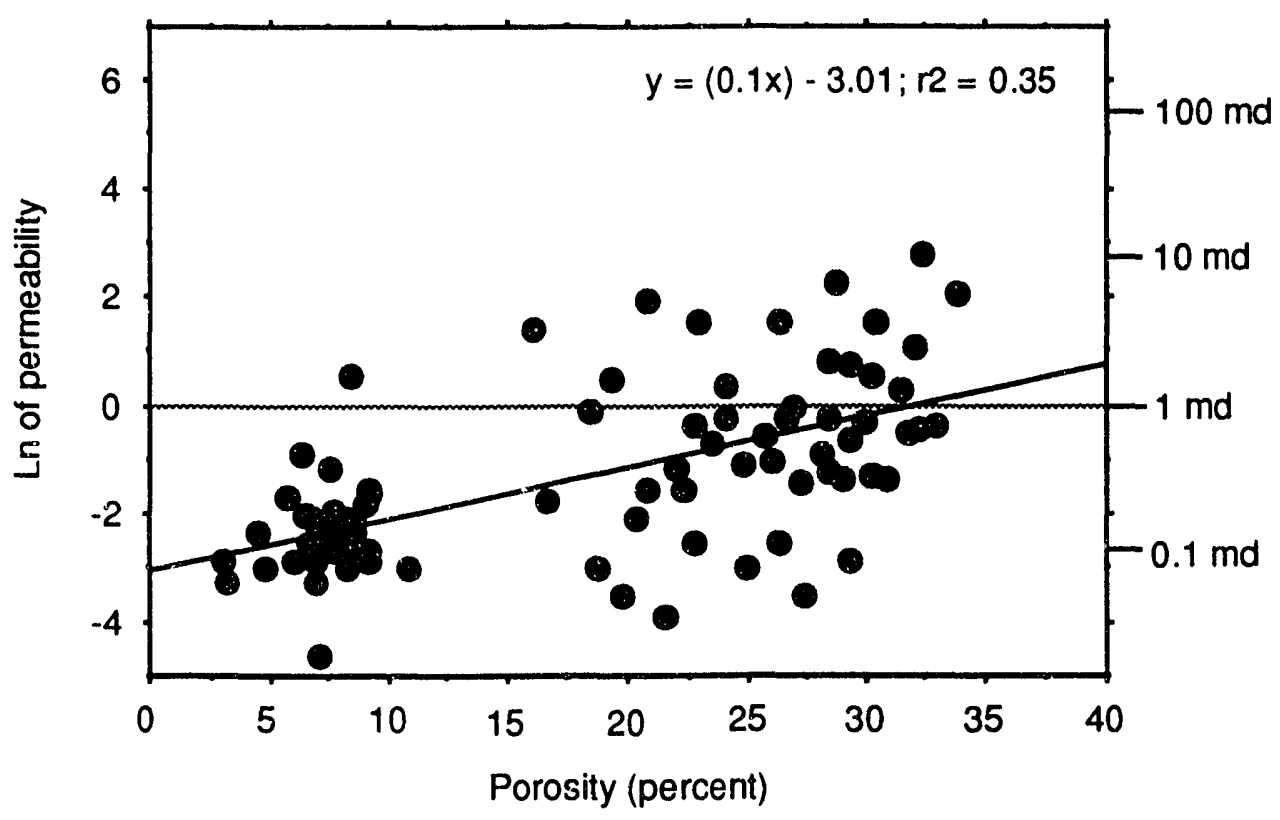

Figure CRC-6.--Porosity vs. natural log permeability plot of two cores combined, Crosbys Creek field, Alabama. Equation applies to regression line. 
Table CRC-1.--Reservoir characterization sheet, Smackover pool, Crosbys Creek field, Washington County, Alabama

\section{Discovery well}

Operator: Hughes Eastern Petroleum Ltd.

Permit number: 5001

Well Name: Sarah Middleton 34-11 \#1

Location: Sec. 34, T8N-R4W

Completion date: $10 / 26 / 88$

Perforations: $16,394-16,420 \mathrm{ft}$

Initial flow rate: 823 bcpd, 2,621 Mcfd, 20/64 ck, 1,975 psi

Field data (as of 12/31/90)

Number of wells within field limits: 3

Producing wells in pool: 2

Production wells in field: 2

Shut-in/Temp. abandoned wells: 0

Plugged and abandoned wells: 0

Salt water disposal wells: 0

Enhanced recovery wells: 0

Dry holes: 1

Drilling wells: 0

Unit spacing (acres): 640

Total field area (acres): 1,280

Cumulative production

Condensate (bbl): 688,145

Gas (Mcf): 1,328,588

Water (bbl): 2,150

\section{Reservoir data}

Trap type: Structural

Reservoir structure: Anticline

Proven productive area (acres): 486

Average net pay thickness (feet): 22

Hydrocarbon type: Gas condensate

Oil gravity (API): na

Initial reservoir pressure (psia): 7,710

Current reservoir pressure (psia): 5,387

Reservoir drive: Depletion

Type of enhanced recovery: none

Mean porosity (core) (\%): 21.40

Porosity standard deviation (\%): 9.20

Maximum porosity (\%): 33.70

Minimum porosity (\%): 6.30

Number of porosity analyses: 58

Geometric mean perm (core) (md): 0.59

Maximum permeability (md): 17.00

Minimum permeability (md): 0.10

Number of permeability analyses: 58

Dykstra-Parsons coefficient: na 


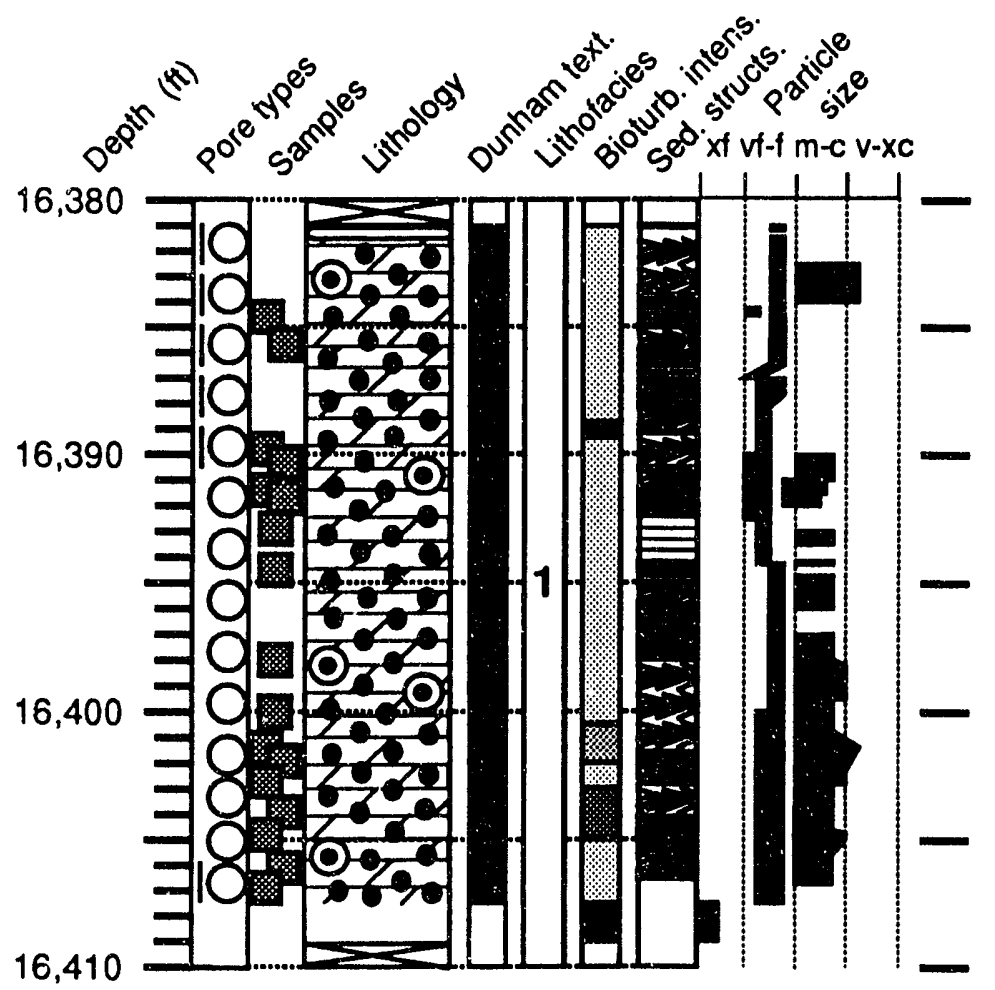

Figure CRC-7.--Detailed core log, Darly Dees 3-3 No. 1 well, Permit No. 5115, Crosbys Creek field, Alabama. 
Table CRC-2.--Lithofacies description of core from Darly Dees 3-3 No. 1 well, Permit No. 5115, Crosbys Creek field, Alabama (see figure CRC-7)

Lithofacies 1: Pellet dolograinstone

Pore types:

Moldic: $93 \%$

Interparticle: $7 \%$

Depositional Environment: High-energy shoreface and/or beach. The abundance of low-angle cross stratification suggests either beach laminae or hummocky cross stratification; the presence of abundant trough cross strata and of local fenestrae suggests beach deposition.

Diagenesis: Early (marine?) pore-rimming cementation, pervasive fabric-selective dolomitization, leaching of unstable particles. Subsequent minor fracturing, calcite cementation, anhydrite nodule growth (replacive), stylolitization.

Percent of reservoir: 100

Depth interval(s) (ft): $16,381-16,407.5$ 


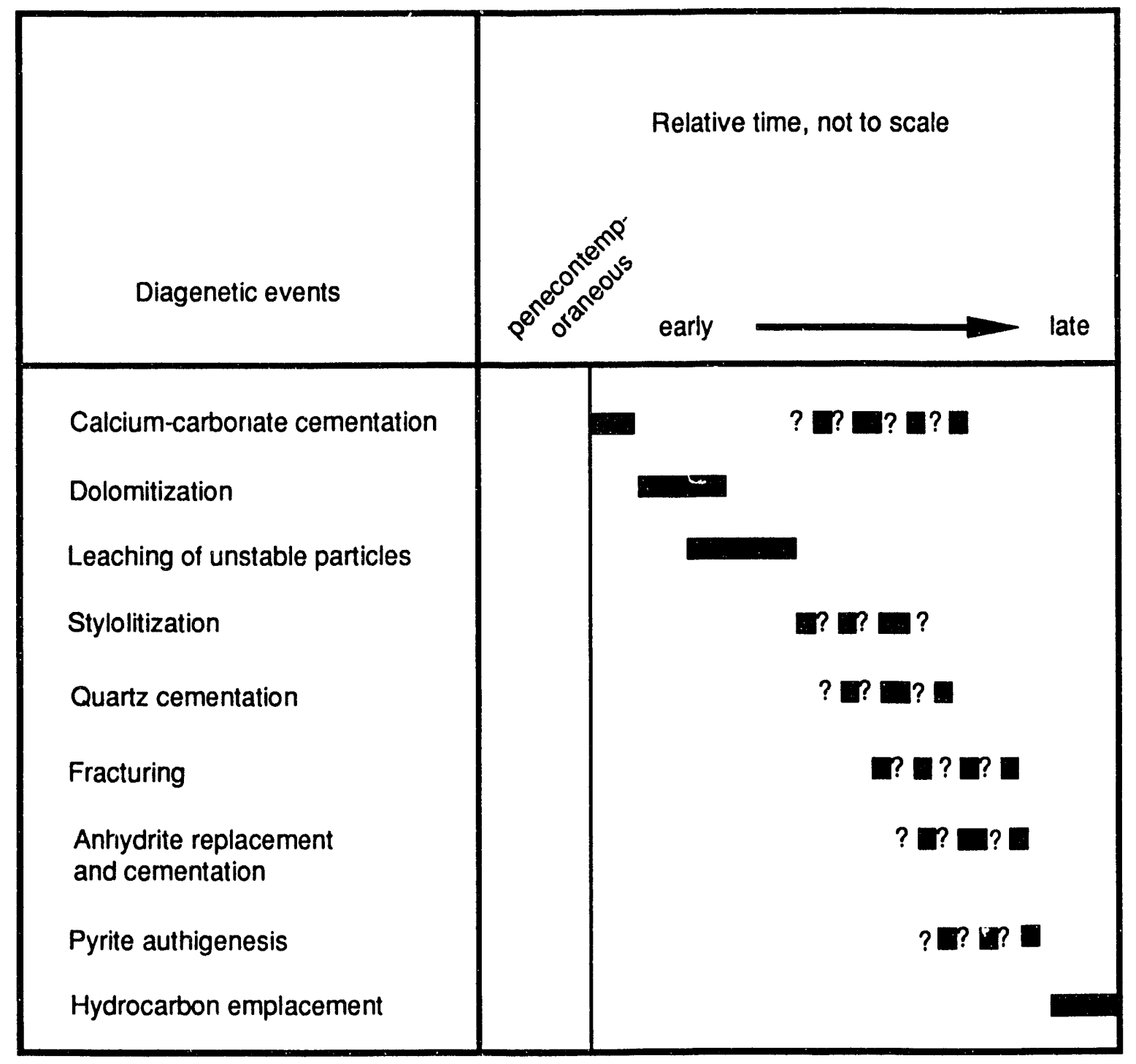

Figure CRC-8.--Paragenetic sequence, Darly Dees 3-3 No. 1 well, Permit No. 5115, Crosbys Creek field, Alabama. 
EAST BARNETT FIELD

SMACKOVER OIL POOL

CONECUH AND ESCAMBIA COUNTIES, ALABAMA 

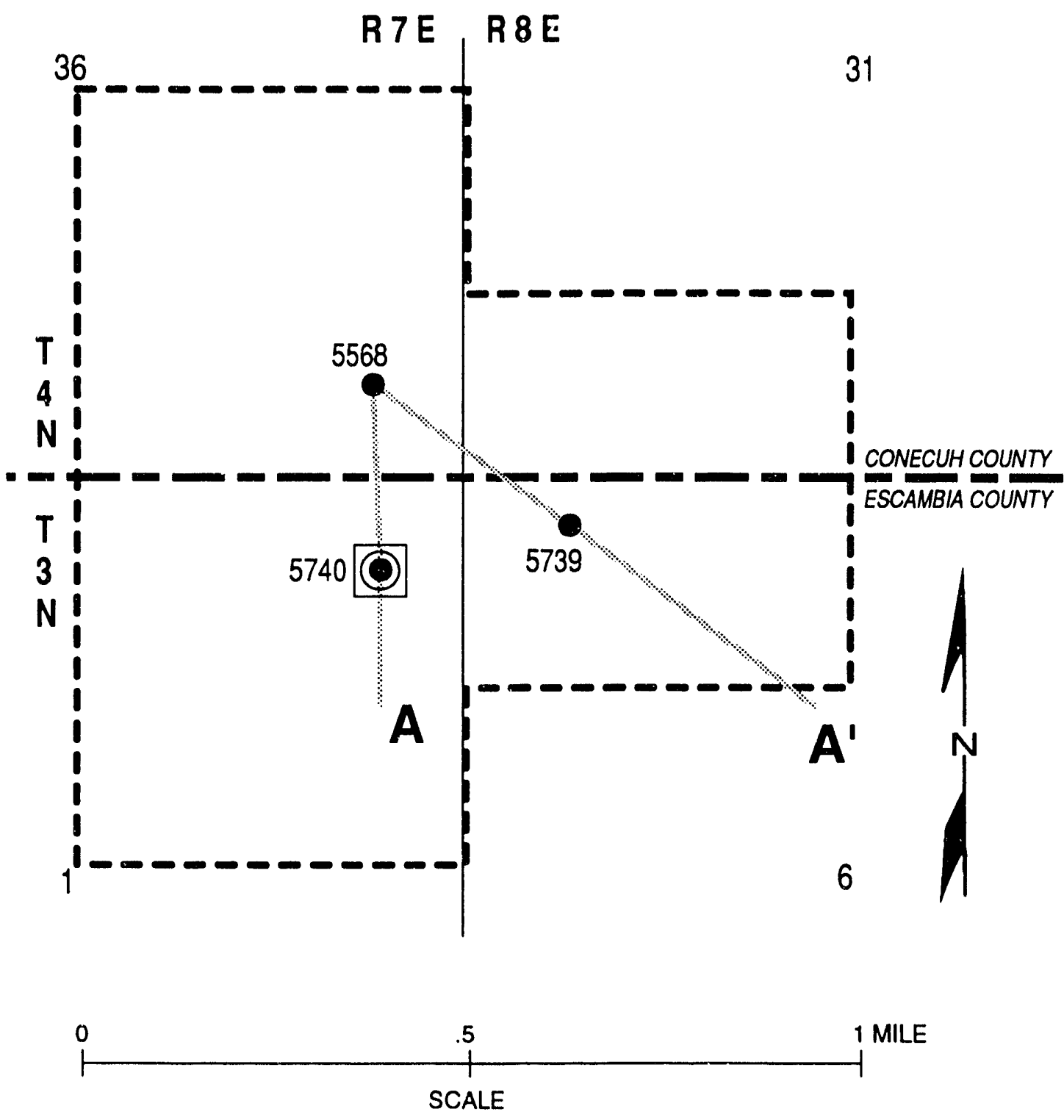

Figure EB-1.--Index map of East Barnett field, Alabama. 


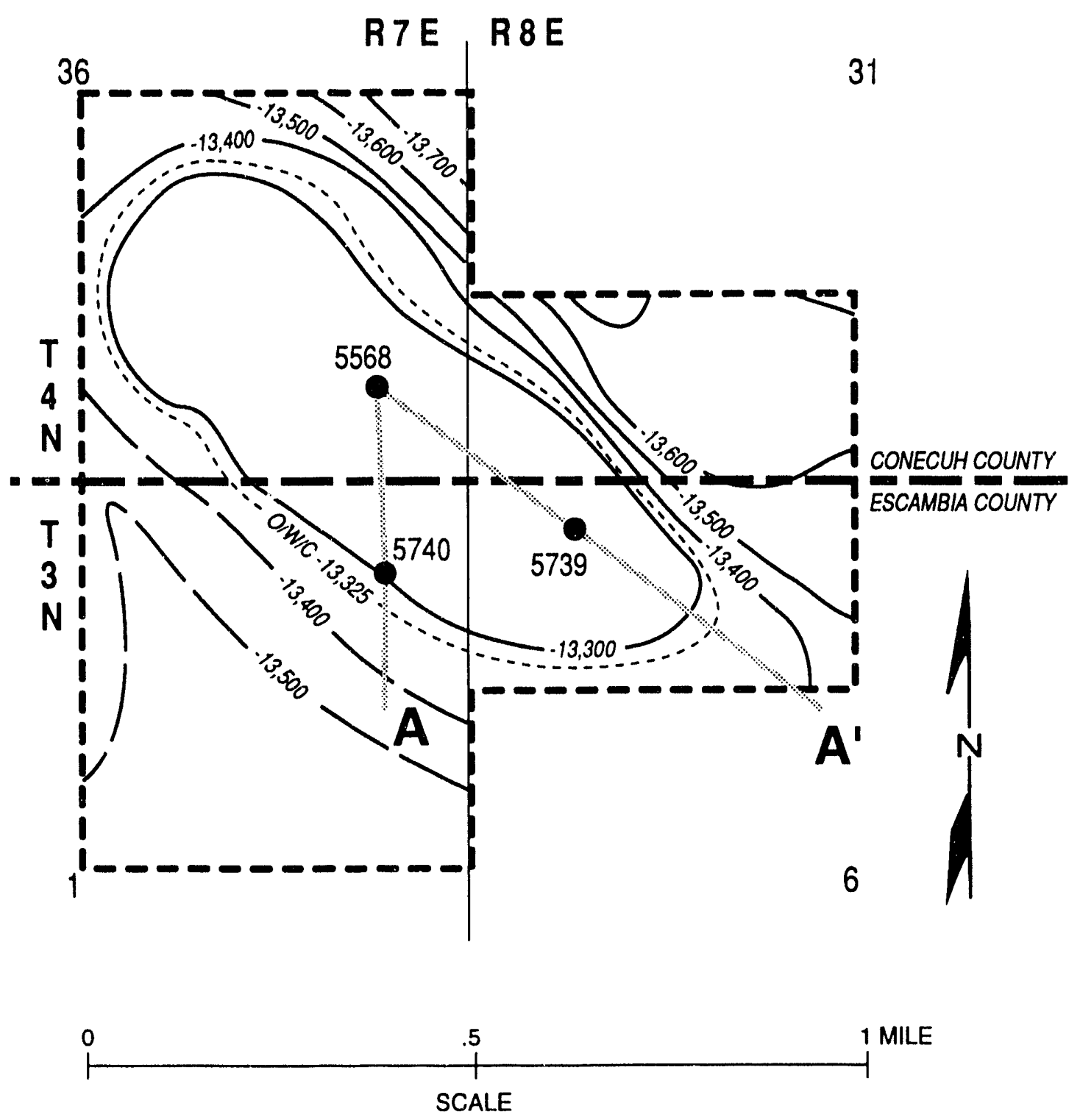

Figure EB-2.--Structure contour map on top of Smackover Furmation in East Barnett field, Alabama. 


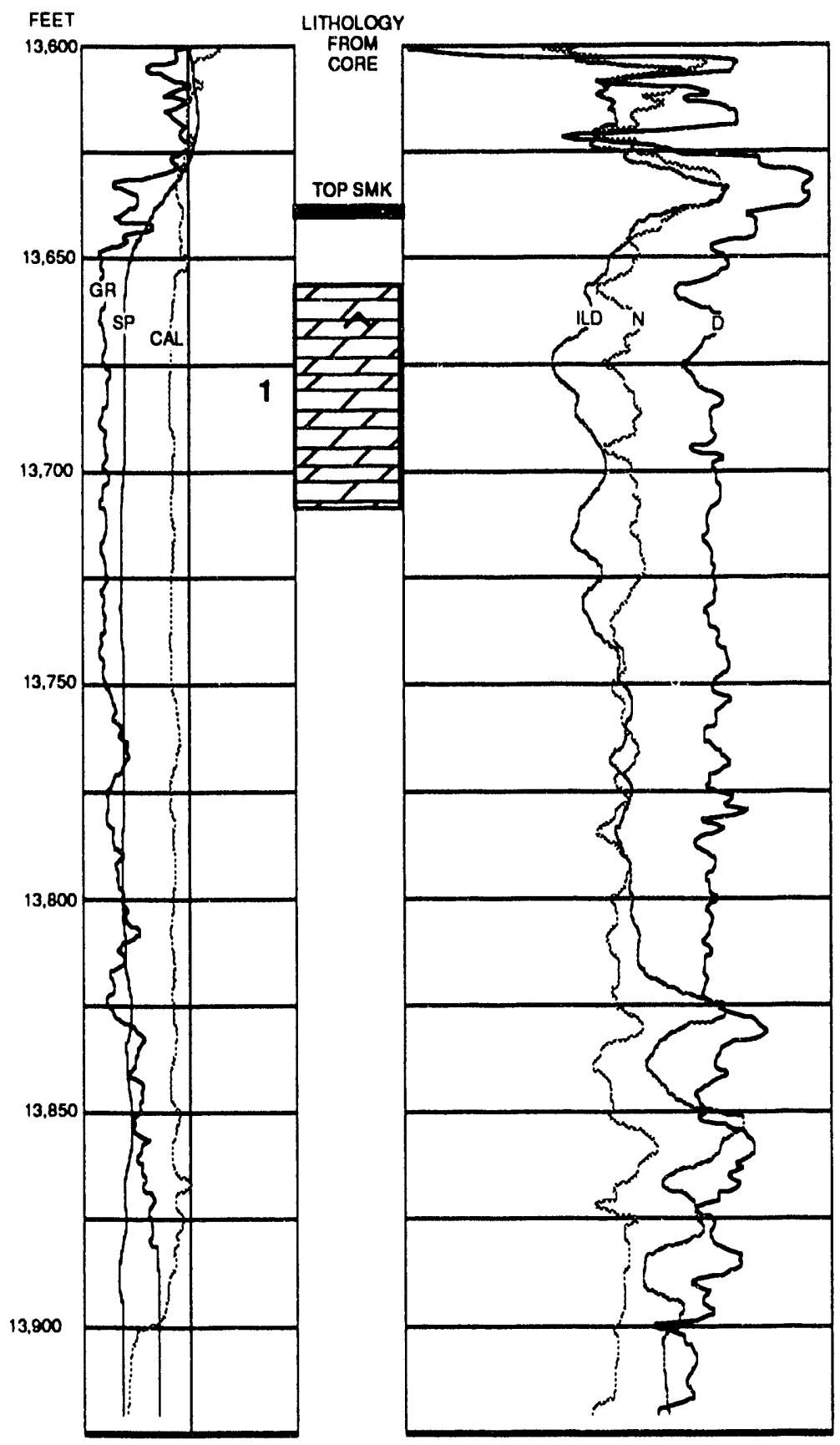

Figure EB-3.--Well log correlated to lithology, Scott Paper Co. et al. 1-1 No. 1 well, Permit No. 5740, East Barnett field, Alabama. 


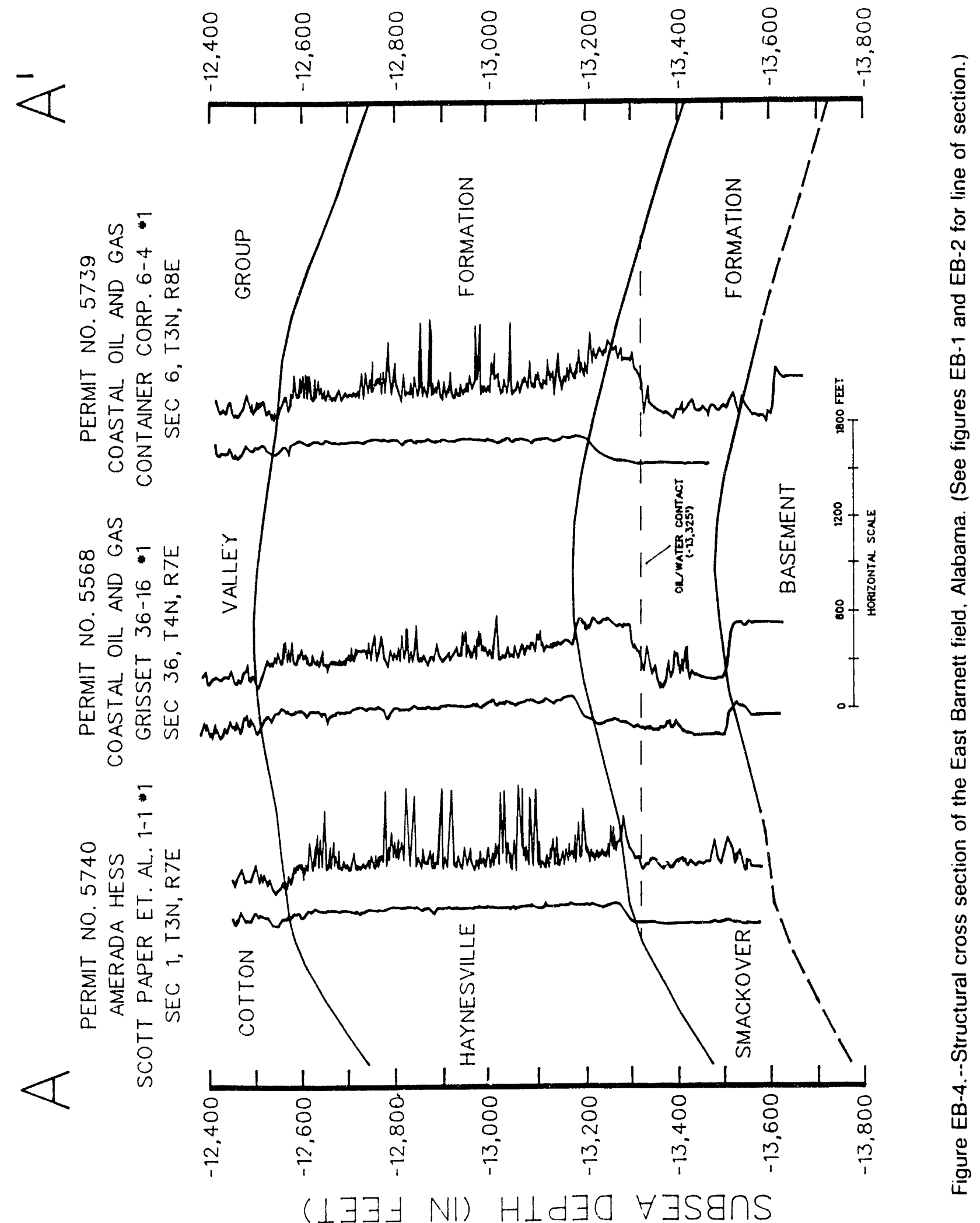



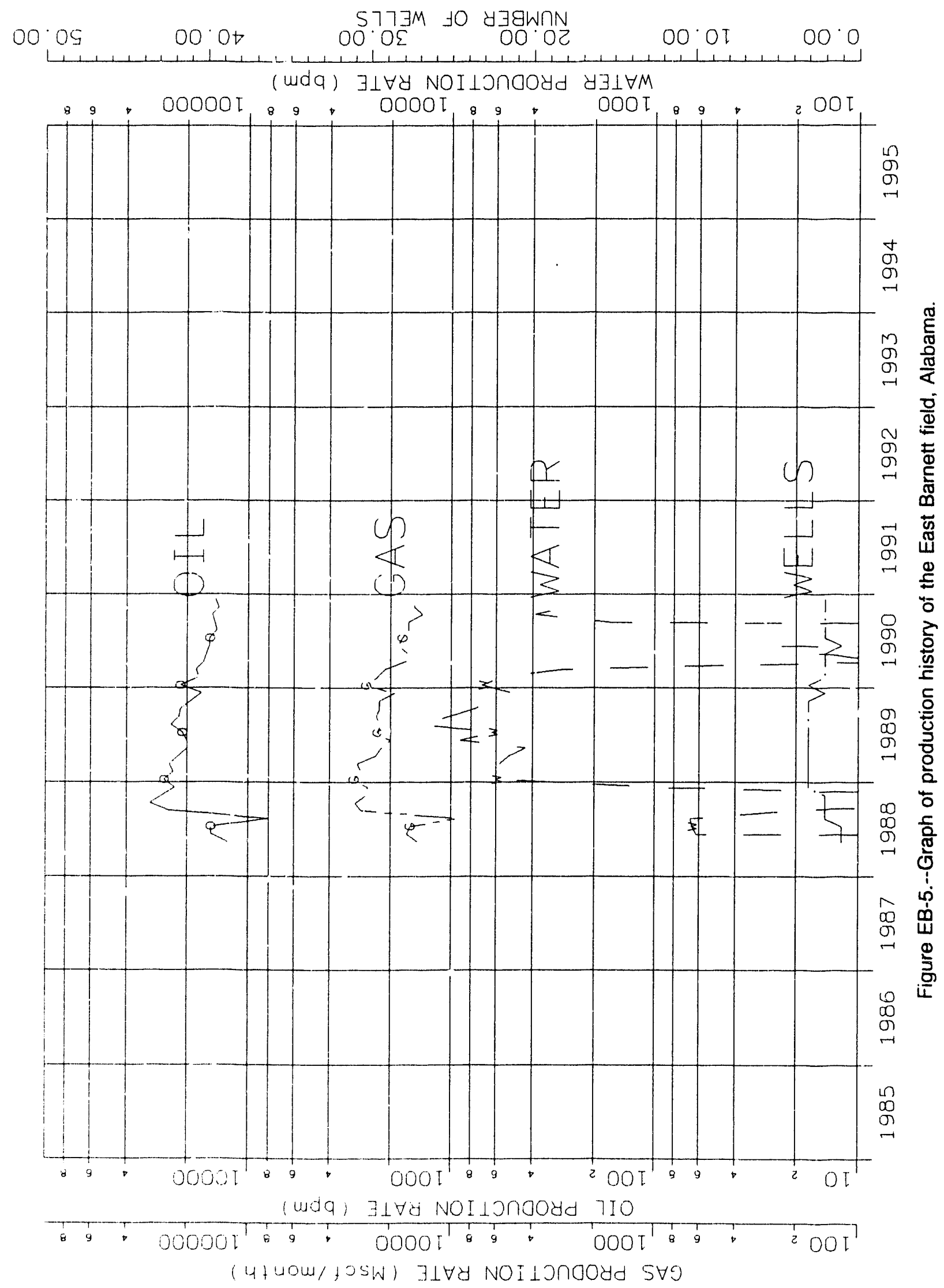
Table EB-1.--Reservoir characterization sheet, Smackover pool, East Barnett field, Conecuh County, Alabama

\section{Discovery well}

Operator: Coastal Oil \& Gas Corp.

Permit number: 5568

Well Name: Grissett 36-16 \#1

Location: Sec. 36, T4N-R7E

Completion date: 04/27/88

Perforations: $13,580-13,659$ it

Initial flow rate: 606 bopd, 1,022 Mcfd,

$$
12 / 64 \mathrm{ck}
$$

\section{Field data (as of 12/31/90)}

Number of wells within field limits: 3

Producing wells in pool: 3

Production wells in field: 3

Shut-in/Temp. abandoned wells: 0

Plugged and abandoned wells: 0

Salt water disposal wells: 0

Enhanced recovery wells: 0

Dry holes: 0

Drilling wells: 0

Unit spacing (acres): 160

Total field area (acres): 480

Cumulative production

Oil (bbl): 565,798

Gas (Mcf): 626, 177

Water (bbl): 107,003

\section{Reservoir data}

Trap type: Structural

Reservoir structure: Anticline

Proven productive area (acres): 337

Average net pay thickness (feet): 58

Hydrocarbon type: Oil

Oil gravity (API): 45.1

Initial reservoir pressure (psia): 6,589

Current reservoir pressure (psia): 6,222

Reservoir drive: Solution gas

Type of enhanced recovery: none

Mean porosity (core) (\%): na

Porosity standard deviation (\%): na

Maximum porosity (\%): na

Minimum porosity (\%): na

Number of porosity analyses: na

Geometric mean perm (core) (md): na

Maximum permeability (md): na

Minimum permeability (md): na

Number of permeability analyses: na

Dykstra-Parsons coefficient: na 


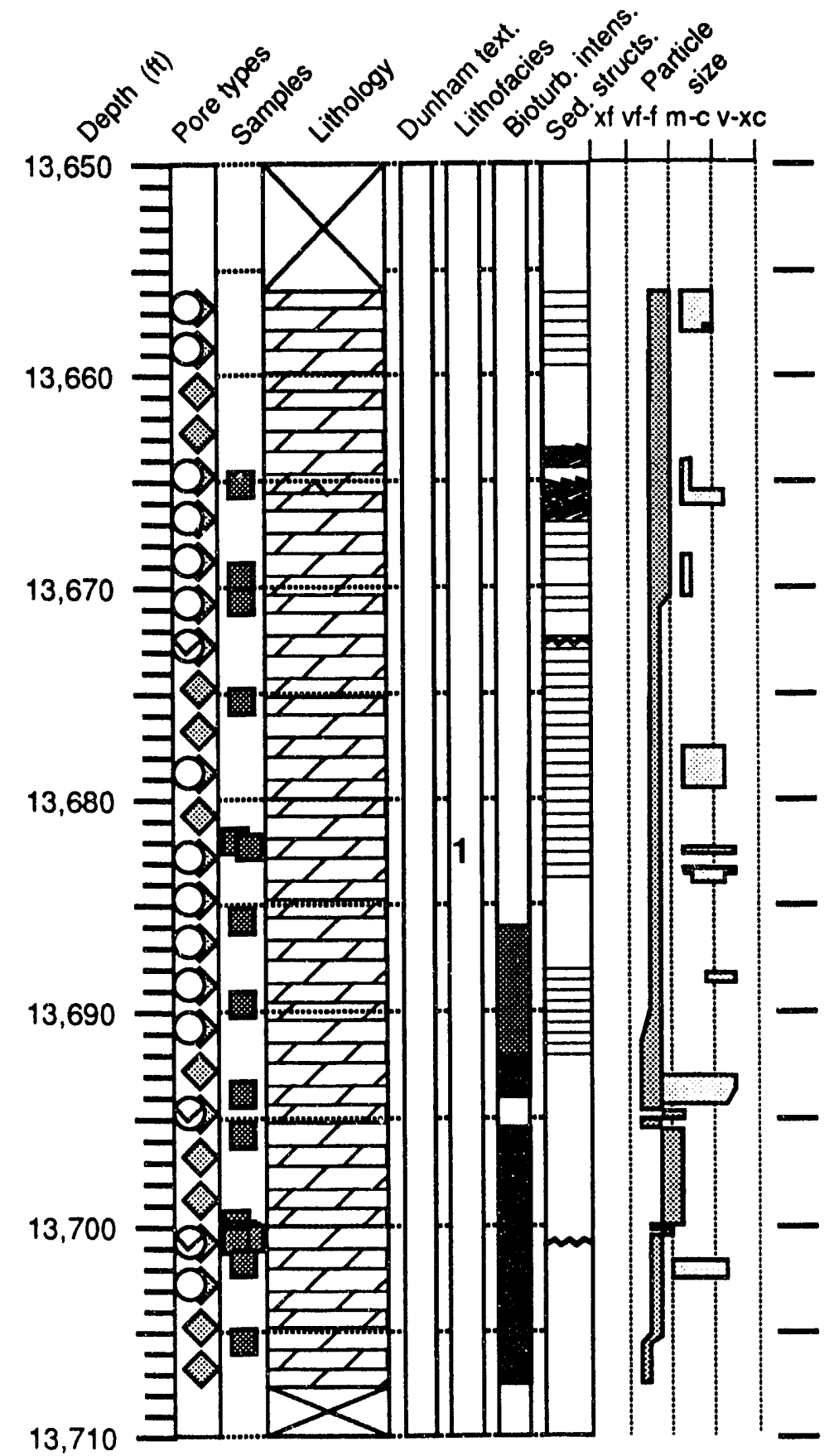

Figure EB-6.--Detailed core log, Scott Paper Co. 1-1 No. 1 well, Permit No. 5740, East Barnett field, Alabama. 
Table EB-2.--Lithofacies description of core from Scott Paper Co. 1-1 No. 1 well, Permit No. 5740, East Barnett field, Alabama (see figure EB-7)

Lithofacies 1: Idiotopic dolostone (planar-e dolostone)

Pore types:

Intercrystalline: $83 \%$

Moldic: $15 \%$

Vuggy: $1 \%$

Secondary Intraparticle: $1 \%$

Depositional Environment: Shallow marine and (?) peritidal.

Diagenesis: Pervasive, nonselective dolomitization; minor anhydrite replacement.

Percent of reservoir: 100

Depth interval(s) (ft): $13,656-13,707.5$ 


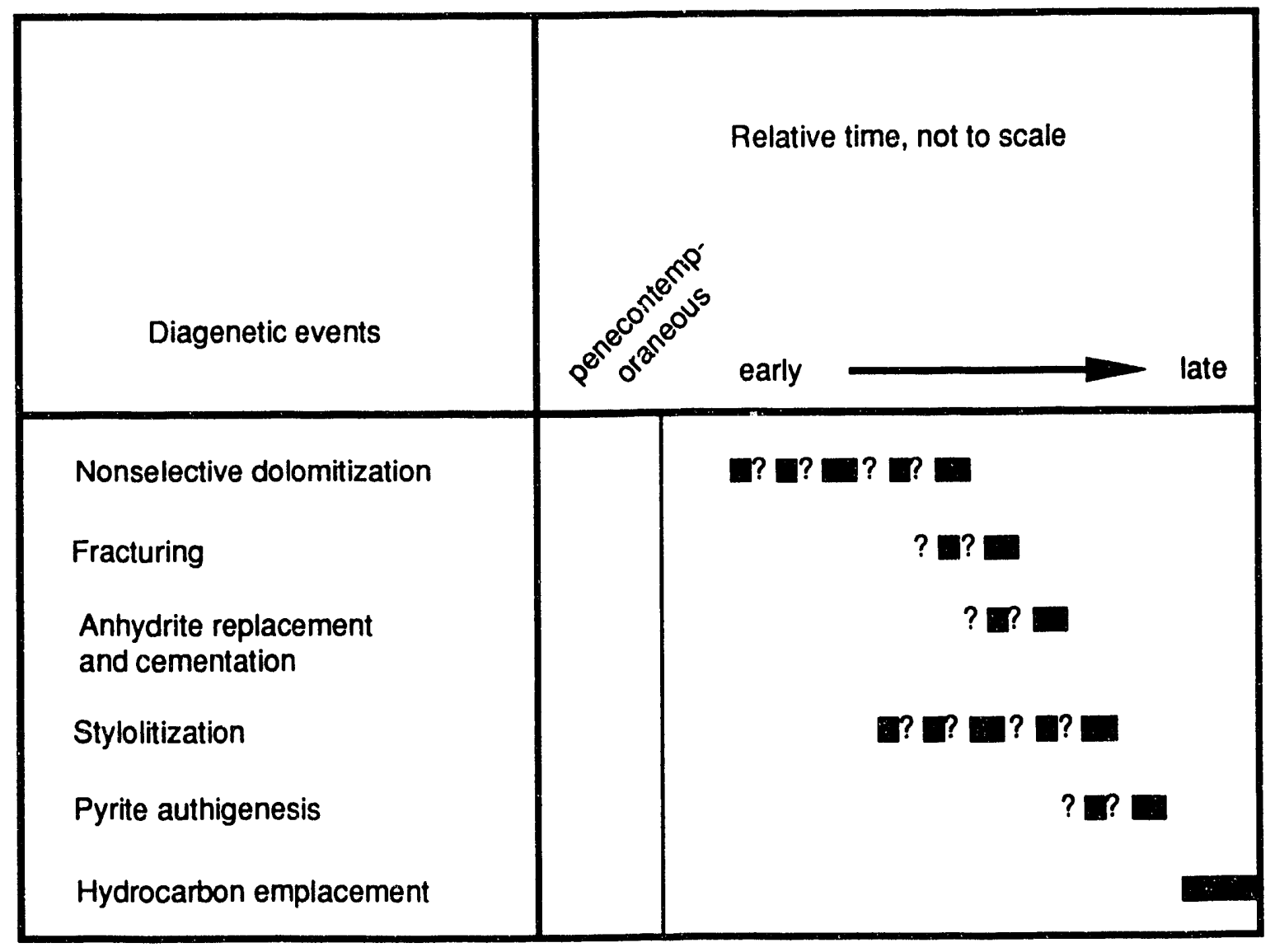

Figure EB-7.--Paragenetic sequence, Scott Paper Co. 1-1 No. 1 well, Permit No. 5740, East Barnett field, Alabama. 

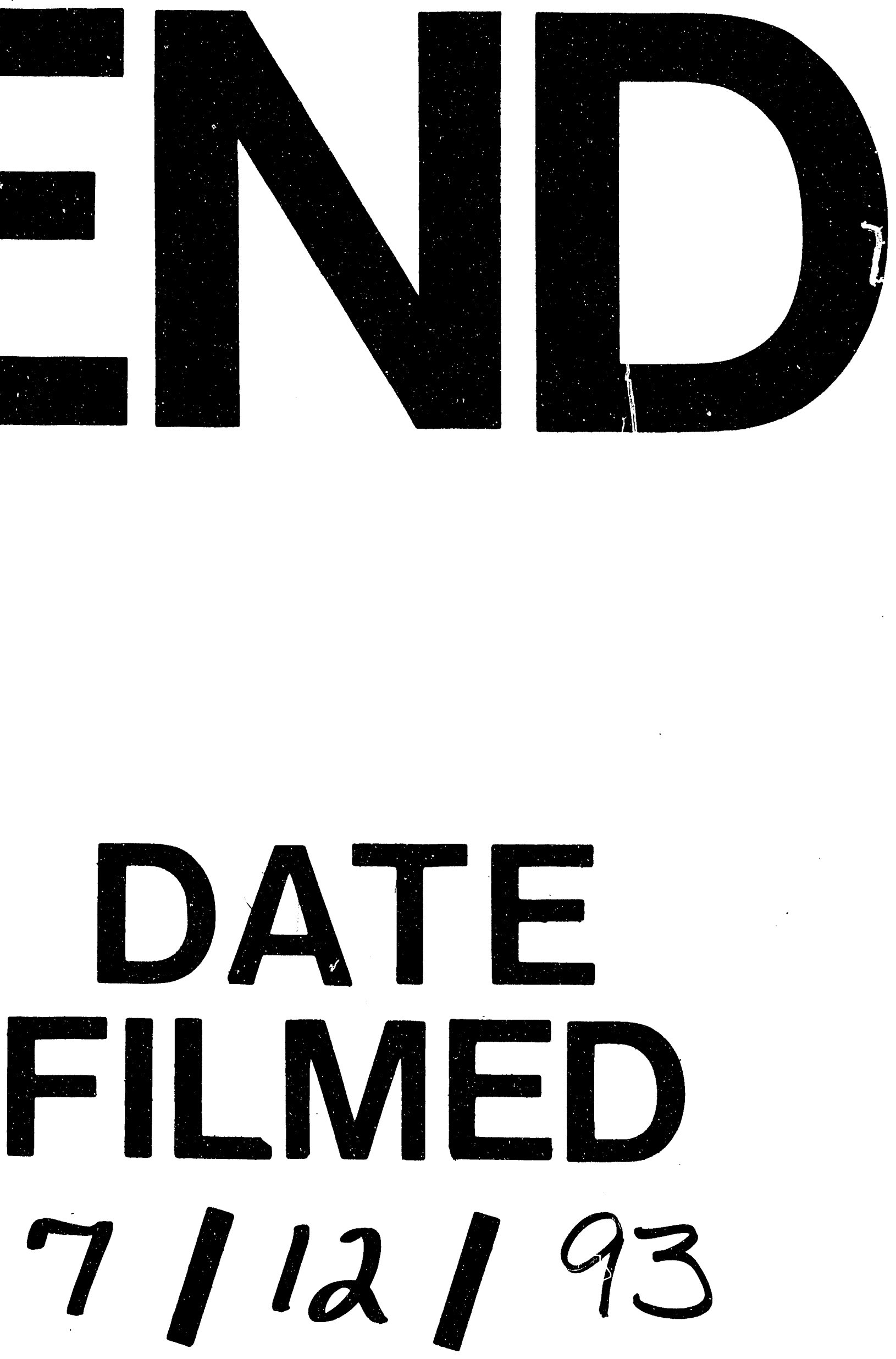
